DANIEL COSTA CASELTA

\title{
RESPONSABILIDADE CIVIL POR DANOS DECORRENTES DA PRÁTICA DE CARTEL
}

Dissertação de Mestrado

Orientador: Professor Dr. José Marcelo Martins Proença

UNIVERSIDADE DE SÃO PAULO

FACULDADE DE DIREITO

SÃO PAULO - SP

2015 


\section{RESPONSABILIDADE CIVIL POR DANOS DECORRENTES DA PRÁTICA DE CARTEL}

Dissertação apresentada à Banca Examinadora do Programa de Pós-Graduação em Direito, da Faculdade de Direito da Universidade de São Paulo, como exigência parcial para obtenção do título de Mestre em Direito, na área de concentração Direito Comercial, sob a orientação do Professor Dr. José Marcelo Martins Proença.

UNIVERSIDADE DE SÃO PAULO

FACULDADE DE DIREITO

SÃO PAULO - SP

2015 
Banca Examinadora 


\section{RESUMO}

CASELTA, Daniel Costa. Responsabilidade Civil por Danos Decorrentes da Prática de Cartel. 203 folhas. Dissertação (Mestrado). Faculdade de Direito. Universidade de São Paulo. São Paulo. 2015.

A presente dissertação de mestrado visa a estudar a responsabilidade civil por danos decorrentes da prática de cartel, a qual é considerada como a mais grave infração à ordem econômica. No primeiro capítulo, o fenômeno do cartel é estudado sob a perspectiva econômica, analisando-se as principais características e efeitos da conduta. No segundo capítulo, examina-se a disciplina jurídica do cartel no direito brasileiro, estudando-se as normas que preveem a responsabilização pela prática de cartel na lei concorrencial e na esfera penal. O terceiro capítulo pretende analisar os objetivos e o papel da responsabilidade civil no contexto mais amplo da política de defesa da concorrência. O quarto capítulo estuda a reparação civil dos danos decorrentes do cartel no direito federal norte-americano e no direito comunitário europeu. $O$ quinto capítulo examina a responsabilidade civil por danos decorrentes da prática de cartel no direito brasileiro. Nesse contexto, são examinados os pressupostos da reparação civil (ato ilícito, culpa, nexo causal e dano), a legitimidade ativa e passiva para as ações indenizatórias, a interação entre a responsabilidade civil e o programa de leniência, bem como a prescrição da pretensão indenizatória. No sexto capítulo, são analisadas algumas propostas de reforma do ordenamento jurídico brasileiro para aperfeiçoamento do sistema de reparação civil em matéria de cartel. Finalmente, a conclusão procura expor de maneira sistematizada as principais ideias apresentadas ao longo do trabalho, bem como avaliar o estágio atual da responsabilidade civil por danos decorrentes da prática de cartel no direito brasileiro.

Palavras-chave: direito concorrencial, infração à ordem econômica, cartel, responsabilidade civil, ato ilícito, nexo causal, dano, sobrepreço. 


\begin{abstract}
CASELTA, Daniel Costa. Civil Liability for Damages Arising from Cartel Behavior. 203 pages. Dissertation (Master). Faculty of Law. University of São Paulo. São Paulo. 2015.

This dissertation aims to study the civil liability for damages arising from cartel behavior, which is considered the most serious antitrust violation. The first chapter studies the cartel from an economic perspective, analyzing the key features and effects of the conduct. The second chapter examines the legal framework regarding cartel behavior under Brazilian law, by studying the rules that provide for the responsibility for cartel under antitrust law and at the criminal level. The third chapter aims to analyze the objectives and the role of civil liability in the broader context of antitrust policy. The fourth chapter studies the civil liability for damages arising from cartel behavior in US federal law and European Community law. The fifth chapter examines the civil liability for damages resulting from cartel behavior in Brazilian law. In this context, the chapter examines the requisites for civil liability (tort, fault, causation and damage), standing to sue and to be sued, the interaction between the indemnification claims and the leniency program, as well as the statute of limitations. The sixth chapter discusses some proposals to reform the Brazilian legal framework with the purpose of improving the system of civil liability concerning cartel behavior. Finally, the conclusion seeks to expose in a systematic way the main ideas presented throughout the work, and to assess the current state of civil liability for damages resulting from cartel behavior in Brazilian law.
\end{abstract}

Key-words: antitrust law, antitrust violation, cartel, civil liability, tort, causation, damage, overcharge. 


\section{AGRADECIMENTOS}

Agradeço imensamente ao meu orientador, Professor Doutor JosÉ MARCELO MARTINS PROENÇA, pela oportunidade de desenvolver este tema e pela preciosa orientação ao longo do trabalho. Agradeço também aos membros da minha banca de qualificação, Professor Associado José FERnANDo SimÃo e Professora Doutora JULIANA KRUEGER PELA, cujas observações e sugestões muito contribuíram para o resultado final do trabalho.

Agradeço aos meus colegas e amigos de escritório. Em especial, agradeço a AURÉLIO MARCHINI SANTOS, pela oportunidade de ter contato com o direito concorrencial, pelo incentivo e pelos importantes comentários à dissertação. E a LUIZ EDUARDO MALTA CORRADINI, pelo apoio e amizade durante a pós-graduação.

Por fim, agradeço muitíssimo à minha família, em especial à minha esposa Lívia GARCIA KeRR do AMARAl CASElTA, com quem tenho a alegria de conviver em cada momento da minha vida e que, além de fornecer a inspiração e motivação fundamentais ao longo do mestrado, teve o carinho e a paciência de ler e comentar todas as versões deste trabalho. À minha filha ISABEL AMARAL CASELTA, que nasceu durante a pós-graduação e encheu nossas vidas de alegria e de motivação. Aos meus pais, EDUARDo CASELTA e ARlete Caselta, pelo exemplo, carinho e apoio ao longo de toda a vida. Também merecem menção Priscila Caselta, Cláudio Amaral e Denise Amaral, e tantos outros familiares e amigos queridos que não conseguiria citar neste espaço. 


\section{SUMÁRIO}

INTRODUÇÃO 10

PARTE I - CARTEL: EFEITOS ECONÔMICOS E DISCIPLINA JURÍDICA...... 16

1. A PRÁTICA DE CARTEL E SEUS EFEITOS SOBRE O MERCADO ........16

1.1 Estruturas de mercado: concorrência perfeita, monopólio e oligopólio ................... 16

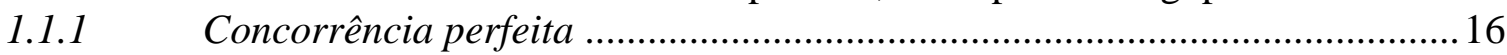

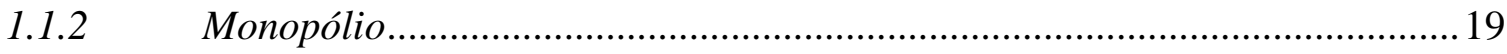

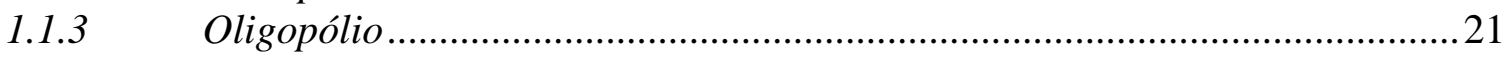

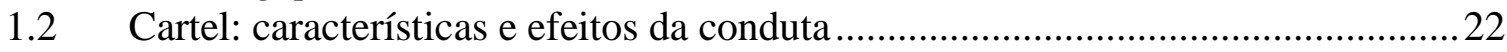

1.2.1 Características dos cartéis e condições de mercado que facilitam sua formação e manutenção ..........................................................................22

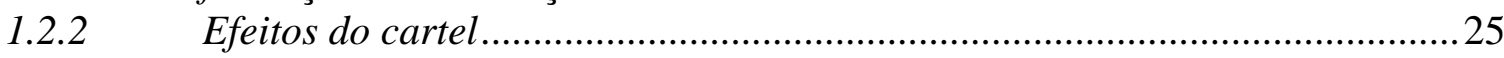

2. A DISCIPLINA JURÍDICA DO CARTEL NO DIREITO BRASILEIRO ...27

2.1 Evolução das normas de defesa da concorrência no Brasil ......................................27

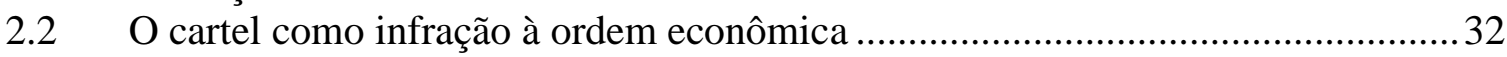

2.2.1 A disciplina das infrações à ordem econômica na Lei 12.529/2011 .................32

2.2.2 A caracterização do cartel como infração à ordem econômica.........................36

2.2.2.1 Jurisprudência do CADE em matéria de cartel .........................................39

$2.3 \quad$ Esfera penal: o crime de cartel ....................................................................... 46

PARTE II - CARTEL E RESPONSABILIDADE CIVIL ………….........................

3. O PAPEL DA RESPONSABILIDADE CIVIL NO CONTEXTO DA DEFESA DA CONCORRÊNCIA ……………………………...........................51

3.1 O objetivo de reparação dos danos sofridos pelos prejudicados ..............................52

3.2 O objetivo de prevenir a prática de infrações concorrenciais...................................53

4. RESPONSABILIDADE POR DANOS DECORRENTES DA PRÁTICA DE CARTEL NO DIREITO ESTRANGEIRO ..............................................59

$4.1 \quad$ Estados Unidos .......................................................................................

4.1.1 Panorama da disciplina dos cartéis no direito federal norte-americano ......60

4.1.2 Ações indenizatórias por infrações concorrenciais no direito federal norteamericano: condenação ao pagamento do triplo dos prejuizos ("treble damages")

4.1.3 Interação entre as ações indenizatórias e o programa de leniência: exceção à regra de "treble damages" .......................................................................63

4.1.4 Exigência de ocorrência de "dano concorrencial" ("antitrust injury") ........65

4.1.5 Exigência de relação próxima do prejudicado com a infração concorrencial: a chamada "pass-on defense" e a legitimidade de compradores diretos $e$ indiretos no direito norte-americano

4.1.6 Prova e quantificação dos danos e demonstração do nexo causal no direito

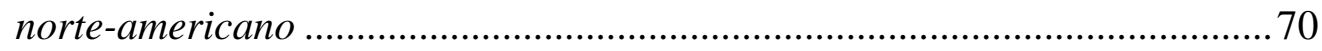

4.1.7 Prescrição da pretensão indenizatória.........................................................71

4.1.8 Outras particularidades: tutela coletiva por meio de "class actions" e inexistência de direito de regresso entre os membros do cartel condenados 72 
4.2 União Europeia

4.2.1 A reparação de danos decorrentes de práticas anticompetitivas no direito comunitário europeu .................................................................................... 74

4.2.2 Iniciativas da Comissão Europeia com o objetivo de fomentar a responsabilidade civil em matéria concorrencial ......................................... 75

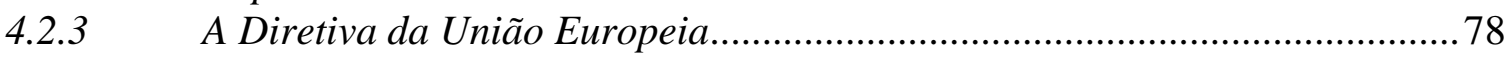

4.3 Comparação entre os modelos norte-americano e europeu segundo os diferentes objetivos da prevenção de infrações e reparação de danos ................................... 81

5. RESPONSABILIDADE CIVIL POR DANOS DECORRENTES DA PRÁTICA DE CARTEL NO DIREITO BRASILEIRO

5.1 Responsabilidade civil por danos decorrentes da prática de cartel no direito

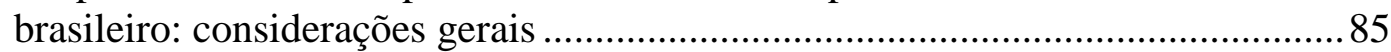

5.1.1 A responsabilidade civil no Código Civil e o art. 47 da Lei 12.529/2011 .....85

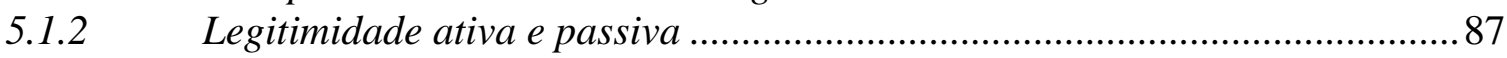

5.2 Pressupostos da responsabilidade civil por danos decorrentes da prática de

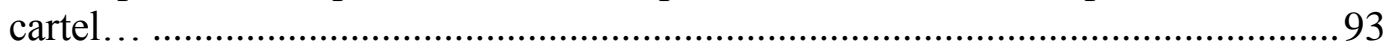

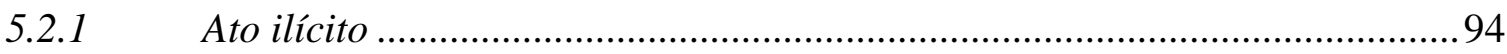

5.2.1.1 "Stand-alone suits" e "follow-on suits": caráter vinculante da decisão condenatória na esfera penal e independência da decisão na esfera

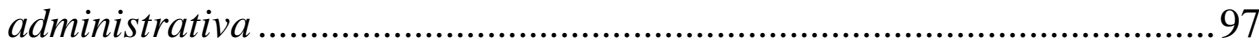

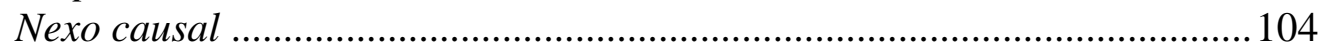

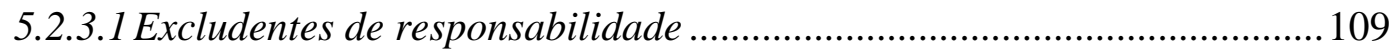

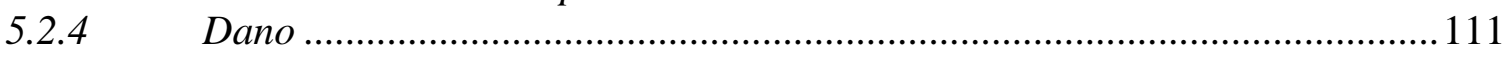

5.2.4.1 Danos patrimoniais (ou materiais) ........................................................ 115

5.2.4.1.1 Prova e quantificação do sobrepreço ................................................ 116

5.2.4.1.2 Principais métodos de quantificação do sobrepreço............................ 119

5.2.4.1.3 Compatibilidade dos métodos de quantificação do sobrepreço com o direito brasileiro

5.2.4.1.4 Considerações sobre a admissão da chamada "pass-on defense" no direito brasileiro

5.2.4.1.5 Possibilidade de cumulação de indenização por danos emergentes e lucros cessantes decorrentes do cartel.................................................... 130

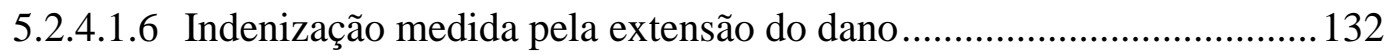

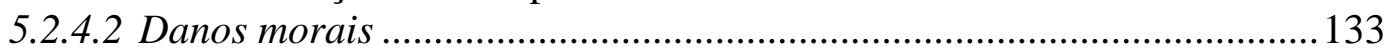

5.2.4.2.1 Reparação dos danos morais no direito brasileiro ............................. 133

5.2.4.2.2 Danos morais decorrentes da prática de cartel .................................. 139

5.2.4.2.3 Fixação da indenização por danos morais ........................................ 142

5.3 Interação entre as ações indenizatórias e o programa de leniência no direito

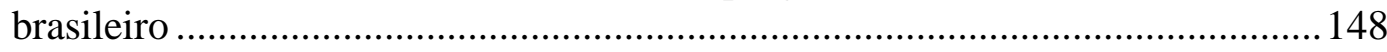

5.3.1 O acordo de leniência no direito brasileiro .................................................. 148

5.3.2 Acesso dos prejudicados às confissões e documentos disponibilizados pelos beneficiários da leniência ............................................................................ 150

5.3.3 Inexistência de limitação à responsabilidade civil dos beneficiários da

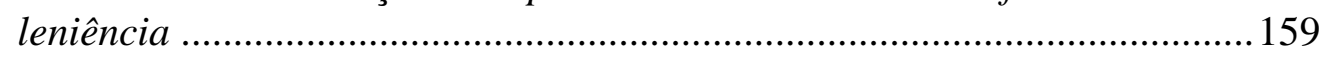

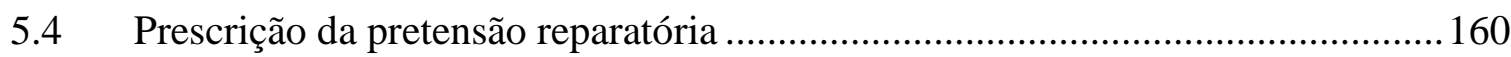

5.4.1 Prazo e termo inicial da prescrição ............................................................ 160

5.4.2 Início do prazo prescricional caso a prática também constitua crime: artigo 200 do Código Civil................................................................................. 163 


\section{ANÁLISE DE PROPOSTAS DE REFORMA DO ORDENAMENTO}

JURÍDICO BRASILEIRO .

6.1 Análise da proposta de adoção de um fator multiplicador da indenização como forma de desestimular a prática de cartel

6.2 Análise da proposta de atribuição de caráter vinculante (ou de presunção relativa) às decisões do CADE com relação à existência do cartel

6.3 Início do prazo prescricional apenas após o conhecimento do dano e suspensão do prazo na pendência de processo administrativo no CADE.

6.4 Disciplina da interação entre o programa de leniência e as ações de responsabilidade civil

7. CONCLUSÃO 


\section{INTRODUÇÃO}

A defesa da concorrência no Brasil experimentou impressionante desenvolvimento nas últimas duas décadas. Após a entrada em vigor da Lei no 8.884 , de 11 de junho de 1994, que transformou o Conselho Administrativo de Defesa Econômica ("CADE") em autarquia, institucionalizou-se no país um efetivo regime de controle de concentrações empresariais e foi adotada paulatinamente uma política consistente de repressão da prática de infrações à ordem econômica. Esse desenvolvimento culminou, mais recentemente, na promulgação da Lei $\mathrm{n}^{\circ}$ 12.529, de 30 de novembro de 2011, que, dentre outras modificações, aperfeiçoou a estrutura institucional do CADE.

Um campo em que esses avanços se fizeram notar com particular intensidade foi a prevenção da conduta conhecida como cartel, considerada a mais grave infração concorrencial. O cartel pode ser definido como um acordo entre competidores com o objetivo de fixar em conjunto suas principais variáveis de atuação, como preços, quantidades, qualidade e/ou mercados de atuação. Por meio do cartel, os concorrentes buscam eliminar a competição entre si com o objetivo de fazer com que os preços e lucros no mercado atinjam patamares semelhantes aos que vigorariam em uma situação de monopólio ${ }^{1}$.

Em virtude dos enormes prejuízos causados pela conduta, que se traduzem em preços mais elevados aos consumidores e danos colaterais à economia como um todo, os cartéis costumam ser alvo prioritário dos esforços das autoridades concorrenciais ao redor do mundo. No Brasil, o cartel é objeto de normas que proíbem a prática e preveem a responsabilização dos infratores em três esferas distintas e complementares: administrativa, penal e civil.

No âmbito administrativo, o art. 36 da atual lei concorrencial (Lei $\mathrm{n}^{\mathrm{o}}$ 12.529/2011) define as práticas caracterizadas como infração à ordem econômica e apresenta rol exemplificativo de condutas, dentre elas o cartel, passíveis de punição pelo

\footnotetext{
${ }^{1}$ CALIXto SAlomão Filho, escrevendo sobre os cartéis, ensina que "a colusão horizontal aqui tratada restringe-se às hipóteses de acordo puro, em que o objetivo é primordialmente a fixação conjunta de uma das variáveis concorrenciais. (...) Se os acordos aqui tratados são puros, seus objetos só podem ser as principais variáveis concorrenciais. São elas, sem dúvida, preço, quantidade, qualidade e mercado" (Direito Concorrencial - As Condutas, $2^{\mathrm{a}}$ ed., São Paulo, Malheiros, 2007, p. 262).
} 
CADE. Desde 1999, quando proferiu a primeira decisão aplicando multa pela prática de cartel, o CADE proferiu dezenas de decisões condenatórias em casos de cartel, aplicando multas aos infratores que totalizam bilhões de reais ${ }^{2}$.

Embora parcela significativa dessas decisões administrativas não tenha resultado, até o momento, em efetivo recolhimento das multas por parte das empresas e indivíduos condenados - que na maioria dos casos recorrem ao Poder Judiciário com o objetivo de tentar anular a decisão do CADE, em processos cuja tramitação costuma demorar vários $\operatorname{anos}^{3}-$, o fato é que os esforços das autoridades fizeram com que o combate aos cartéis ingressasse definitivamente na realidade jurídica brasileira, a exemplo do que ocorre há muitos anos em outros países.

$\mathrm{Na}$ esfera penal, o art. $4^{\circ}$ da Lei $\mathrm{n}^{\circ}$ 8.137, de 27 de dezembro de 1990 tipifica a prática de cartel como crime, punível com pena de reclusão de dois a cinco anos e multa. Nos últimos anos, verificaram-se avanços significativos na persecução penal de cartéis, com o aumento na quantidade de ações penais e com a adoção de iniciativas importantes nessa matéria, tais como a criação de grupos especializados de combate a cartéis pelos Ministérios Públicos estaduais e pela Polícia Federal.

As penalidades aplicadas nas esferas administrativa e penal, contudo, não têm a função de reparar os prejuízos causados pelos cartéis, cabendo aos eventuais prejudicados ingressar em juízo para obter indenização. Com efeito, embora seja entendimento consolidado da doutrina que o objeto precípuo de proteção das normas

\footnotetext{
${ }^{2}$ Em relatório sobre as instituições e normas de defesa da concorrência no Brasil, a Organização para a Cooperação e Desenvolvimento Econômico ("OCDE") fez interessante resumo sobre o desenvolvimento do controle de condutas anticompetitivas no país. De acordo com o relatório, "a partir de 2000, o SBDC começou a se concentrar no combate a cartéis. Em 1999, foi concluído o que muitos consideram ser o primeiro verdadeiro caso de cartel no Brasil, ocorrido na indústria de aço. Em 2000 uma alteração na Lei de Defesa da Concorrência conferiu ao SBDC dois novos importantes poderes: a possibilidade de realizar buscas e apreensões e o de instituir um programa de leniência. Entretanto, esses poderes foram subutilizados por alguns anos. (...) A situação começou a mudar em 2003. O SBDC adotou novos procedimentos que tornaram as análises de atos de concentração mais eficientes, liberando recursos para a atividade de combate a cartéis. (...) Nos últimos anos, especialmente a partir de 2006, o programa de combate a cartéis do SBDC cresceu de forma constante" (Direito e Política da Concorrência no Brasil: Uma Revisão pelos Pares, 2010, disponível em: <http://www.oecd.org/dataoecd/4/41/45154401.pdf>. Acesso em: 22.mar.2013, pp. 14-15).

${ }^{3}$ A respeito do controle exercido pelo Poder Judiciário sobre as decisões do CADE, vide: FABRíCIO ANTONIO CARDIM DE AlMEIDA (coord.), Revisão Judicial das Decisões do Conselho Administrativo de Defesa Econômica (CADE) - Pesquisa Empírica e Aplicada sobre os Casos Julgados pelos Tribunais Regionais Federais (TRFs), Superior Tribunal de Justiça (STJ) e Supremo Tribunal Federal (STF), Belo Horizonte, Fórum, 2011.
} 
concorrenciais é a própria concorrência - e não os concorrentes e consumidores diretamente $^{4}-$, o ordenamento não exclui a reparação dos prejuízos sofridos pelos prejudicados como consequência de práticas lesivas à concorrência.

Nesse sentido, além da regra geral de responsabilidade civil prevista no art. 927 do Código Civil, o art. 47 da Lei 12.529/2011 dispõe expressamente que os prejudicados pela prática de infrações à ordem econômica poderão ingressar em juízo para obter indenização por perdas e danos. E o fato é que, em decorrência da maior atenção conferida à prevenção de cartéis nos últimos anos, percebe-se recentemente uma tendência - ainda incipiente, mas crescente - de ajuizamento de demandas judiciais por empresas, órgãos estatais e indivíduos prejudicados, bem como pelo Ministério Público, pleiteando a reparação dos danos decorrentes da prática de cartel ${ }^{5}$.

Trata-se, contudo, de faceta da defesa da concorrência ainda pouco explorada no direito brasileiro. A quantidade de demandas desse tipo em tramitação no Brasil ainda é ínfima em comparação com outros países onde o direito concorrencial se desenvolveu há mais tempo, como, por exemplo, os Estados Unidos ${ }^{6}$.

\footnotetext{
${ }^{4}$ José Marcelo Martins Proença, Concentração Empresarial e o Direito da Concorrência, São Paulo, Saraiva, 2001, p. 50.

${ }^{5}$ Como exemplo de ações ajuizadas por particulares, podem ser citadas as ações indenizatórias movidas contra as empresas do mercado de vergalhões de aço, ajuizadas na esteira de decisão condenatória proferida pelo CADE (Ação Ordinária $n^{\circ}$ 2009.34.00.035755-7, 13 ${ }^{\text {a }}$ Vara Federal da Seção Judiciária do Distrito Federal; Processo $\mathrm{n}^{\mathrm{o}}$ 2009.38.00.015651-4, $17^{\text {a }}$ Vara Federal da Seção Judiciária de Minas Gerais - Belo Horizonte; e Processo n ${ }^{\circ}$ 9848158-78.2006.8.13.0024, $22^{a}$ Vara Cível da Comarca de Belo Horizonte). Neste último caso foi proferida sentença condenando os réus a indenizarem os prejuízos causados. Há também ações civis públicas sobre o tema, dentre as quais podem ser mencionadas as seguintes, nas quais foi proferida decisão condenatória: revenda de combustíveis em Guaporé-RS (TJ/RS, Apelação Cível $\mathrm{n}^{\circ}$ 70018714857, $3^{\text {a }}$ Câmara Cível, Rel. Paulo de Tarso Vieira Sanseverino, j. 12.07.2007); revenda de combustíveis em José Bonifácio-SP (TJ/SP, Apelação Cível n ${ }^{\circ}$ 994.03.009153-6, 11 a Câmara de Direito Público, Rel. Des. Luiz Ganzerla, j. 08.02.2010); revenda de combustíveis em Jaboticabal-SP (Ação Civil Pública $\mathrm{n}^{\circ}$ 291.01.2006.000904-1, Juíza de Direito Carmen Silva Alves, Comarca de Jaboticabal - SP, j. 20.05.2008); distribuição de GLP na região metropolitana de Porto Alegre-RS (Ação Civil Pública ${ }^{\circ}$ 97.00.21424-9-RS, Juíza Federal Paula Beck Bohn, Subseção de Porto Alegre - RS, j. 13.01.2010); revenda de combustíveis em Santa Maria-RS (Ação Civil Pública nº 027/1.05.0004158-2, Juíza de Direito Stefânia Frighetto Schneider, $14^{\mathrm{a}}$ Vara Cível de Santa Maria-RS, j. 28.12.2010); e revenda de combustíveis em

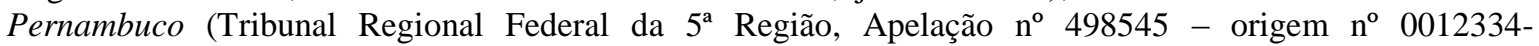
56.1999.4.05.8300, $3^{\mathrm{a}}$ Turma, Relator Des. Federal Luiz Alberto Gurgel de Faria, j. 22.11.2012).

6 JOHN M. CONNOR, escrevendo sobre a reparação dos danos decorrentes de cartéis nos Estados Unidos, estima que "in the United States, private parties recovered at least $\$ 19.7$ billion from defendants in international cartels during 1990-2008" ("The Impact of International Cartels", in ALBERT A. FOER e JonAthan W. CunEO (org.), The International Handbook of Private Enforcement of Competition Law, Cheltenham, Edward Elgar Publishing, 2010, p. 22).
} 
Nesse sentido, este trabalho pretende analisar a responsabilidade civil por danos decorrentes da prática de cartel no direito brasileiro. Trata-se de tema de inegável importância: a responsabilidade civil é internacionalmente reconhecida como peça fundamental na política de prevenção de cartéis e outras práticas anticompetitivas.

A possibilidade de receberem indenizações pelos danos sofridos incentiva os próprios prejudicados a denunciarem a conduta anticompetitiva e a ingressarem em juízo para fazê-la cessar e obter reparação, complementando assim os esforços de prevenção empreendidos pelas autoridades de defesa da concorrência.

No Brasil, o CADE há algum tempo vem ressaltando a importância das demandas indenizatórias no contexto da política de defesa da concorrência, embora reconheça que ainda há muito a ser feito para estimular o ajuizamento de demandas desse tipo e assegurar o efetivo ressarcimento dos prejuízos causados pelos cartéis. A título de exemplo, veja-se trecho da seguinte decisão do CADE:

\begin{abstract}
"A multa imposta pelo Conselho não repara os danos patrimoniais e morais causados a pessoas específicas. A indenização de tais danos deve ser engendrada pelas vias judiciais cabíveis. A via de maior destaque é a ação civil pública. (...) Merece destaque ainda a ação privada, ajuizada pela vítima de cartel em busca de reparação pelos danos causados. A utilidade das ações privadas para promoção da concorrência já foi comprovada em jurisdições estrangeiras. Nos Estados Unidos, onde a lei estabelece que os prejudicados por um cartel têm direito a um valor equivalente a três vezes a indenização ordinariamente cabível, a litigância privada já se transformou em peça chave da política da concorrência no país. Trata-se de mais um desestímulo à infração da lei. No Brasil, porém, quase não se tem notícia de ações privadas em razão de danos causados por cartéis. Perde-se, assim, um importante fator a desestimular a prática de conluio. E os prejudicados também deixam de ser ressarcidos pelos danos causados",
\end{abstract}

O trabalho proposto é interdisciplinar, pois, além de envolver o exame dos pressupostos da responsabilidade civil, pressupõe a análise dos conceitos e princípios específicos de direito concorrencial aplicáveis à matéria.

Nesse ponto, cabe registrar que, se o direito da concorrência experimentou notável avanço nos últimos anos, o estudo da responsabilidade civil também passou e tem

\footnotetext{
7 Voto do Conselheiro Relator Fernando de Magalhães Furlan no processo administrativo $\mathrm{n}^{\circ}$ 08012.009888/2003-70, julgado em 01.09.2010.
} 
passado por mudanças importantes. Dentre as principais discussões travadas atualmente no campo da responsabilidade civil, destacam-se o afastamento progressivo da ideia de culpa e migração para uma noção de responsabilidade sem culpa, a ampliação dos danos indenizáveis, a positivação da responsabilidade por abuso de direito e o intenso debate sobre o papel punitivo e preventivo dos danos morais e da responsabilidade civil em geral ${ }^{8}$. Como será detalhado ao longo deste trabalho, o tema da reparação dos danos decorrentes de cartel possibilita a discussão sobre todos os temas acima mencionados.

Revela-se assim a dupla importância deste estudo: sob a ótica concorrencial, o trabalho permite analisar em detalhes uma faceta importante da defesa da concorrência, que ainda não é plenamente explorada no Brasil; sob a ótica de direito civil, o estudo possibilita novo contato com as principais discussões travadas atualmente no campo da responsabilidade civil, o que constitui nova oportunidade para avaliar o estágio atual da disciplina.

Com relação ao escopo do trabalho, deve ser destacado que o estudo abordará apenas a prática de cartel, sem detalhar os pressupostos para a responsabilidade civil pela prática de outras infrações à ordem econômica (como, por exemplo, preços predatórios). Essa abordagem se justifica pelo fato de o cartel ser considerada a mais grave infração à ordem econômica e, também, pelo fato de a maior parte das demandas indenizatórias ajuizadas em matéria concorrencial, tanto no Brasil como em outros ordenamentos, ser relacionada à prática de cartel.

O presente trabalho está dividido em duas partes. Na primeira parte, será inicialmente examinado o cartel sob a perspectiva econômica, estudando-se as características e efeitos da conduta sobre o mercado (capítulo 1). Em seguida, será analisada a disciplina jurídica dos cartéis no direito brasileiro, partindo-se da premissa de que o exame da responsabilidade civil por danos decorrentes da prática de cartel deve ser precedido do estudo das diversas normas que proíbem a conduta no direito brasileiro (capítulo 2).

\footnotetext{
${ }^{8}$ Sobre o assunto, vide: ANDERSON SchreIBER, Novos Paradigmas da Responsabilidade Civil: da Erosão dos Filtros de Reparação à Diluição dos Danos, $5^{\text {a }}$ ed., São Paulo, Atlas, 2013; e TERESA ANCONA LOPEZ, Princípio da Precaução e Evolução da Responsabilidade Civil, São Paulo, Quartier Latin, 2010.
} 
A segunda parte do trabalho é dedicada ao exame específico do cartel e suas implicações sobre a responsabilidade civil. Primeiramente, será examinado o papel da responsabilidade civil no contexto da política de defesa da concorrência (capítulo 3). Será então analisada a legislação, doutrina e jurisprudência de direito estrangeiro sobre a reparação civil dos danos decorrentes de cartel, com enfoque no direito federal dos Estados Unidos e no direito comunitário da União Europeia (capítulo 4). Em seguida, serão examinados os principais aspectos da responsabilidade civil pela prática de cartel no direito brasileiro (capítulo 5), e, ao final, será feita uma avaliação do estágio atual da disciplina e examinadas algumas propostas para aperfeiçoamento do sistema (capítulos 6 e 7). 


\section{PARTE I - CARTEL: EFEITOS ECONÔMICOS E DISCIPLINA JURÍDICA}

\section{A PRÁtica DE CARTEL E SEUS EFEITOS SOBRE O MERCADO}

Este capítulo inicial tem por objetivo introduzir de maneira sucinta conceitos que serão importantes para a compreensão da análise empreendida nos capítulos seguintes, examinando o fenômeno do cartel sob a perspectiva econômica e analisando as principais características e efeitos da conduta. A análise será iniciada pelo estudo das diferentes estruturas de mercado (concorrência perfeita, monopólio e oligopólio) (item 1.1), examinando-se em seguida as características do cartel, as condições facilitadoras da prática e, ao final, os efeitos do cartel sobre o mercado (item 1.2).

\subsection{Estruturas de mercado: concorrência perfeita, monopólio e oligopólio}

Para a compreensão do fenômeno do cartel sob a perspectiva econômica, deve-se inicialmente examinar brevemente as três principais estruturas de mercado comumente estudadas na literatura econômica, a saber: concorrência perfeita, monopólio e oligopólio. A partir da análise dessas diferentes estruturas de mercado, será possível, em seguida, estudar o cartel e examinar os efeitos da conduta.

\subsubsection{Concorrência perfeita}

No exame das estruturas de mercado, deve-se analisar inicialmente o modelo da concorrência perfeita, o qual, apesar de raramente verificado na prática, consiste em ferramenta teórica útil para a avaliação e comparação de diferentes mercados ${ }^{9}$.

De modo geral, determinado mercado é tido como perfeitamente competitivo caso estejam presentes os seguintes requisitos: grande quantidade de

\footnotetext{
${ }^{9}$ Embora seja dificilmente encontrado na prática, alguns mercados se aproximam bastante do modelo de concorrência perfeita, como os mercados internacionais de commodities agrícolas (DAVID A. KREPS, Microeconomics for Managers, New York, W.W. Norton \& Company, 2004, pp. 265-266).
} 
ofertantes, homogeneidade dos produtos ofertados, ausência de barreiras à entrada e saída dos agentes, inexistência de assimetria de informações entre produtores e consumidores, ausência de custos de transação e inexistência de externalidades ${ }^{10}$.

Em um mercado perfeitamente competitivo, nenhum dos agentes isoladamente é capaz de exercer influência sobre o comportamento dos preços, razão pela qual se diz que as firmas no mercado são "tomadoras de preços" ("price takers"), pois praticam os preços que são dados pelo mercado. Os preços e quantidades no mercado em concorrência perfeita são determinados pela lei da oferta e da demanda, conforme gráfico abaixo:

$\underline{\text { Gráfico } 2.1 \text { - Concorrência perfeita }}{ }^{11}$

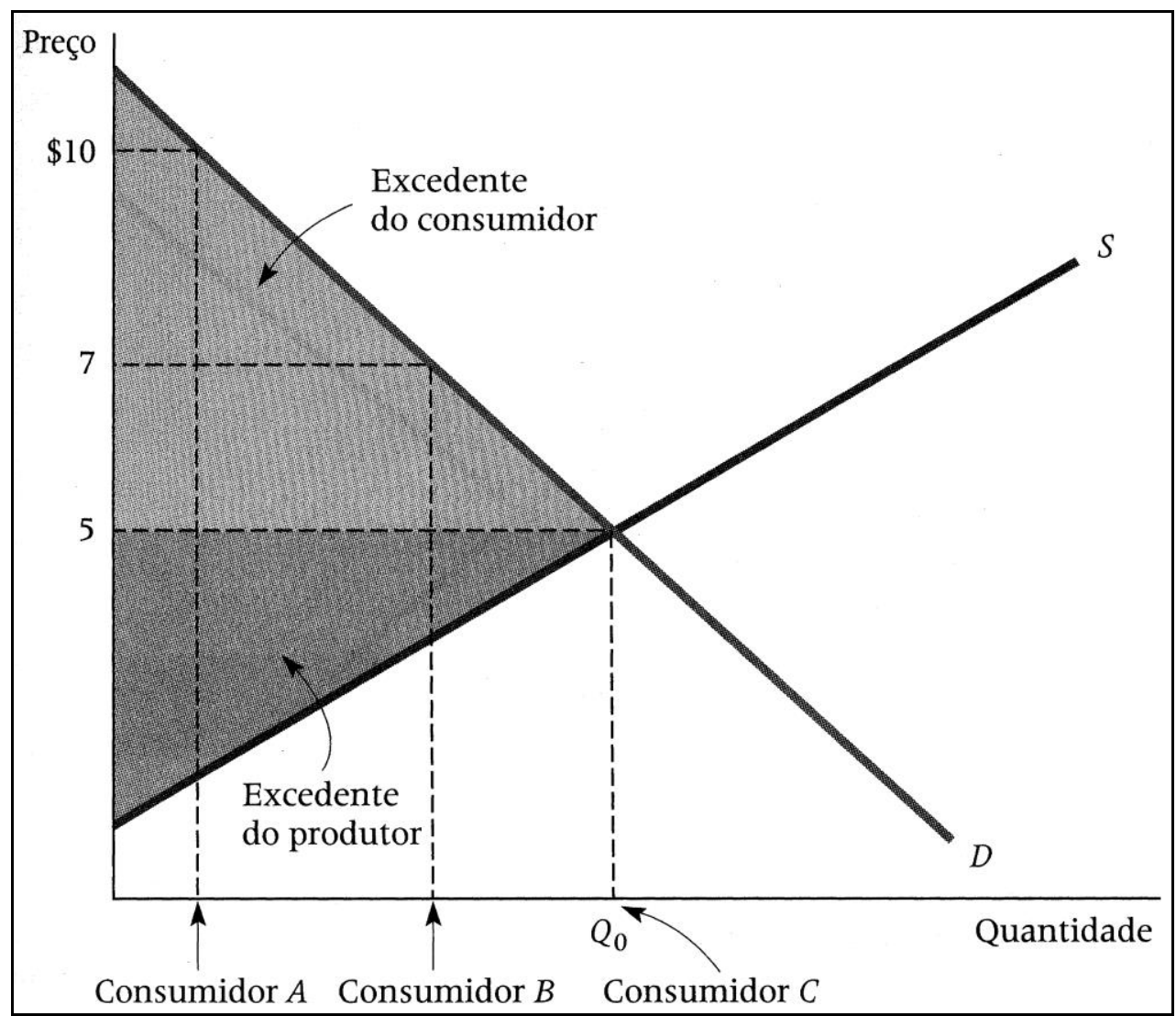

\footnotetext{
${ }^{10}$ Sobre os pressupostos do mercado perfeitamente competitivo, vide: FÁBIO NuSDEO, Curso de Economia: Introdução ao Direito Econômico, $2^{\mathrm{a}}$ ed., São Paulo, Revista dos Tribunais, 1997, p. 263; e GEORGE J. STIGLER, The Organization of Industry, Chicago, University of Chicago Press, 1983, pp. 5-7.

${ }^{11}$ Fonte: Robert S. Pindyck e DAniel L. Rubinfeld, Microeconomia, $6^{\mathrm{a}}$ ed., São Paulo, Pearson Prentice Hall, 2006, p. 255.
} 
Analisando-se o gráfico 2.1, percebe-se o seguinte:

i) a curva de oferta (S) indica o comportamento dos ofertantes, os quais, buscando maximizar seu lucro, tendem a ofertar maiores quantidades do bem quanto maior for o preço pago;

ii) a curva de demanda (D) indica o comportamento dos consumidores, os quais, buscando maximizar sua utilidade, tendem a adquirir maiores quantidades do bem quanto menor for o preço ofertado e, de modo inverso, tendem a adquirir menores quantidades quanto maior o preço;

iii) o preço de equilíbrio (no gráfico, \$5) e a quantidade de equilíbrio (Qc) são obtidos na intersecção entre a curva de oferta e a curva de demanda;

iv) a área sombreada localizada entre a linha de preço de equilíbrio e a curva de demanda indica o chamado "excedente do consumidor", que corresponde ao benefício total que os consumidores recebem além daquilo que efetivamente pagam pela mercadoria (i.e., como se percebe pela análise da curva de demanda, no exemplo acima alguns consumidores estariam dispostos a pagar $\$ 10$ pela mercadoria - o chamado preço de reserva -, mas somente tiveram que desembolsar $\$ 5$, de modo que a soma da diferença, para todas as unidades vendidas, entre o preço de reserva e o preço efetivamente pago corresponde ao excedente do consumidor); e

v) a área sombreada entre a linha do preço de equilíbrio e a curva de oferta é o chamado "excedente do produtor", que mede o benefício total dos produtores, correspondente à soma da diferença, para todas as unidades vendidas, entre o preço de mercado e o custo marginal de produção. 
O mercado perfeitamente competitivo é considerado eficiente pela literatura econômica, por maximizar o chamado "excedente total", ou seja, a soma dos excedentes do consumidor e do produtor $^{12}$.

\subsubsection{Monopólio}

Na estrutura de mercado monopolista, por sua vez, há apenas um ofertante e muitos compradores. Por ser o único agente ofertando determinado bem ou serviço, o monopolista possui poder de influenciar os preços no mercado, razão pela qual, num mercado monopolista, os preços tenderão a ser maiores e a quantidade total ofertada será menor. Os efeitos gerados pelo monopólio são ilustrados no gráfico abaixo:

Gráfico 2.2 - Custo social do monopólio ${ }^{13}$

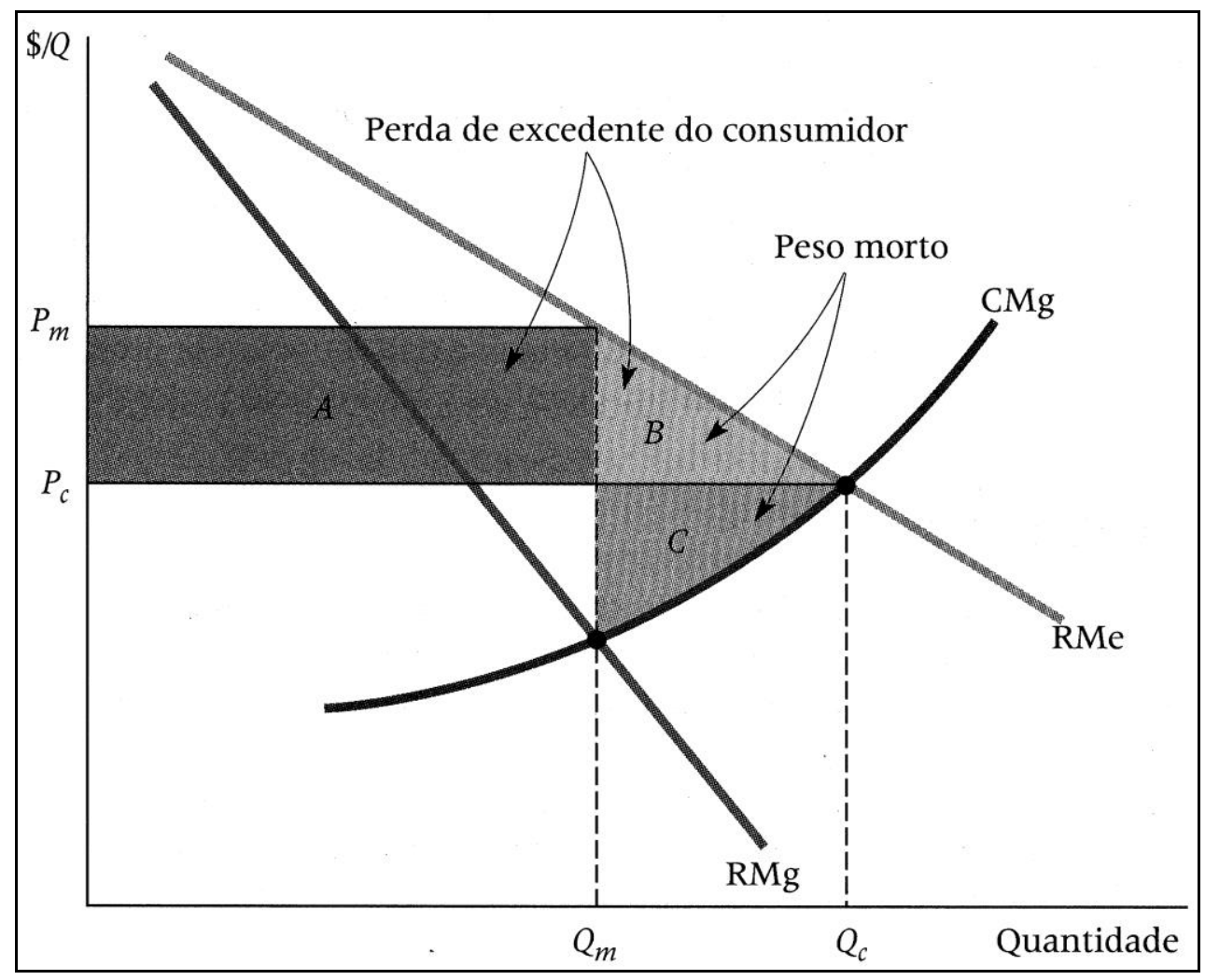

Analisando-se o gráfico 2.1, percebe-se o seguinte:

\footnotetext{
${ }^{12}$ RoBert S. PINDYCK e DANIEL L. RUBINFELD, Microeconomia, cit., pp. 254-262

${ }^{13}$ Fonte: Robert S. PINDYCK e DANIEL L. RUBINFELD, Microeconomia, cit., p. 305.
} 
i) os preços e quantidades que vigorariam em uma situação de competição são representados no gráfico por Pc e Qc; o monopolista, contudo, fixa os preços em patamares mais elevados $(\mathrm{Pm})$, de modo que a quantidade total ofertada é menor $(\mathrm{Qm})$

ii) o retângulo sombreado A representa a parcela do excedente do consumidor que é capturada pelo monopolista em decorrência dos preços mais elevados cobrados, representando uma transferência de renda dos consumidores em benefício do monopolista;

iii) o triângulo sombreado B corresponde aos consumidores que, embora desejassem adquirir o produto pelo preço competitivo, deixam de adquiri-lo em decorrência do preço mais elevado cobrado pelo monopólio;

iv) o triângulo sombreado $\mathrm{C}$, por sua vez, corresponde ao lucro que o produtor teria auferido com a venda das quantidades adicionais que teriam sido vendidas caso o preço praticado fosse o competitivo (e não o preço de monopólio) ${ }^{14}$; e

v) a soma das áreas $\mathrm{B}$ e C corresponde à perda líquida de excedente gerada pelo monopólio, denominada "peso morto", o qual corresponde a um excedente que não é apropriado nem pelo monopolista nem pelo consumidor, resultando em redução geral de bem-estar na sociedade.

Como se percebe, o monopólio gera custo social e resulta em alocação ineficiente de recursos quando comparado com o modelo de concorrência perfeita, eis que, além de haver transferência de renda do consumidor para o monopolista, há perda de excedente líquido total em decorrência do chamado "peso morto".

A literatura econômica aponta que, na realidade, os custos sociais do monopólio são ainda maiores do que o chamado "peso morto". Isso porque a existência do monopólio resulta em outros tipos de ineficiência, tais como: (i) redução dos incentivos

\footnotetext{
${ }^{14}$ Desse modo, o ganho total do monopolista é representado por A - C, pois, como visto no gráfico 2.2, embora se aproprie de parcela do excedente do consumidor correspondente ao retângulo A, o monopolista perde a área $\mathrm{C}$ ao elevar os preços e reduzir a quantidade vendida.
} 
para que o monopolista invista na melhoria dos processos produtivos, qualidade dos produtos e redução de custos; (ii) criação, ademais, de incentivos para que o monopolista passe a dedicar tempo e recursos para manter seu monopólio (o chamado "rent seeking", que pode se materializar, por exemplo, na forma de "lobbying" para obtenção de leis que mantenham o monopólio); e (iii) custos decorrentes da necessidade de as autoridades investirem tempo e recursos na tentativa de coibir a formação de monopólios ${ }^{15}$.

\subsubsection{Oligopólio}

Verifica-se o oligopólio quando o mercado é composto por um pequeno número de agentes responsáveis pela maior parte da oferta. Uma das características do oligopólio é a existência de elevada interdependência entre os agentes econômicos, os quais, na tomada de decisões empresariais, devem levar em conta as estratégias e possíveis respostas dos concorrentes.

Nesse sentido, Robert S. Pindyck e Daniel L. Rubinfeld definem o oligopólio da seguinte forma ${ }^{16}$ :

"Em mercados oligopolistas, os produtos podem ou não ser diferenciados. O
importante é que apenas algumas empresas são responsáveis pela maior
parte ou por toda a produção. (...) O oligopólio é o tipo de estrutura de
mercado que prevalece. Exemplos de setores oligopolistas incluem os
automóveis, aço, alumínio, petroquímica, equipamentos elétricos e
computadores. (...) Na realidade, no caso de quaisquer decisões econômicas
importantes de uma empresa - determinação de preço e de níveis de
produção, realização de uma grande campanha de promoçãa de seus
produtos ou realização de investimentos em capacidade produtiva adicional
-, ela deve procurar determinar quais serão as reações mais prováveis de
seus concorrentes".

Essas características (pequeno número de firmas e elevada interdependência entre os agentes) fazem com que o mercado oligopolista - que, como visto, é o tipo de estrutura de mercado que predomina na prática - seja a estrutura mais propícia para a formação de cartéis $^{17}$, os quais serão estudados no item seguinte.

\footnotetext{
${ }^{15}$ W. KiP VISCUSI, JOHN M. VERNON e JOSEPH E. HARringtON JR., Economics of Regulation and Antitrust, $2^{\text {nd }}$ ed., Cambridge, Massachusetts Institute of Technology Press, 1995, p. 83.

${ }^{16}$ Microeconomia, cit., p. 378-379.

${ }^{17}$ FABIO NUSDEO esclarece que "num oligopólio há uma grande tendência no sentido de se unirem os operadores, os quais passarão então a atuar como na unidade, levando a uma situação de monopólio. (...) O
} 


\subsection{Cartel: características e efeitos da conduta}

\subsubsection{Características dos cartéis e condições de mercado que facilitam sua formação e manutenção}

Este item examinará as características dos cartéis e as condições de mercado que facilitam sua formação e manutenção. Como adiantado, a prática de cartel pode ser definida como um acordo, expresso ou tácito, entre concorrentes com a finalidade de fixar em conjunto as principais variáveis de sua atuação no mercado, tais como preços, quantidade, qualidade e/ou condições de venda dos produtos ou até mesmo os mercados em que cada competidor irá atuar.

Por meio do cartel, as empresas concorrentes em determinado mercado buscam eliminar a concorrência entre si com o objetivo de fazer com que os preços e lucros no mercado atinjam patamares semelhantes aos que vigorariam em uma situação de monopólio $^{18}$.

Os cartéis são arranjos naturalmente instáveis, pois, embora no longo prazo o cartel seja mais lucrativo para os participantes do que o regime de concorrência, os membros do cartel possuem incentivos para traírem o acordo e reduzirem os preços com o propósito de auferirem lucros no curto prazo em razão do aumento da demanda. A tensão enfrentada pelos membros de um cartel entre cumprir ou descumprir o acordo pode ser descrita da seguinte forma:

"(...) the attractiveness of collusion is influenced by two forces. On the one hand, there are the benefits of collusion in the form of higher profits compared with a competitive outcome - the higher this profits, the stronger the benefits to form and maintain a cartel. On the other hand, there are immediate benefits from deviating from the collusive agreement - the higher

oligopólio é, assim, um regime extremamente volátil, pois com base num conluio entre os oligopolistas, chamado cartel, pode transformar-se num monopólio" (Curso de Economia..., cit., p. 267).

${ }^{18}$ Veja-se, nesse sentido, o conceito de cartel apresentado pela Resolução no 20/1999, do CADE: “Cartéis: acordos explícitos ou tácitos entre concorrentes do mesmo mercado, envolvendo parte substancial do mercado relevante, em torno de itens como preços, quotas de produção e divisão territorial, na tentativa de aumentar preços e lucros conjuntamente para níveis mais próximos dos de monopólio". 
the benefits of cheating are to individual cartelists, the more difficult it is to sustain the cartel"19.

Em virtude dessa natural instabilidade dos cartéis, a literatura econômica identifica duas condições essenciais para que o conluio seja bem sucedido. Em primeiro lugar, os membros do cartel devem ser capazes de identificar eventual descumprimento do acordo por um dos membros (por exemplo, prática de preços inferiores ao estabelecido pelo cartel). Em segundo lugar, os participantes devem ser capazes de punir eventuais descumprimentos (por exemplo, estabelecendo em conjunto preços muito baixos como forma de excluir do mercado e/ou causar prejuízos àquele que descumpriu o acordo) ${ }^{20}$.

Com base em tais condições, certas características do mercado são tidas pela literatura econômica como facilitadoras da formação de cartéis, por conferirem maior estabilidade ao arranjo colusivo. Algumas das principais características apontadas pelos economistas são as seguintes:

i) mercado concentrado: quanto menor o número de firmas no mercado, mais fácil será para elas chegarem a um acordo com relação às variáveis competitivas relevantes (preço, qualidade, atuação territorial, etc.) e mais fácil será a fiscalização do cumprimento do acordo; além disso, caso o mercado seja composto por um pequeno número de firmas (cada uma delas com uma fatia relativamente elevada do mercado), os incentivos para descumprir o acordo são menores, pois cada firma, individualmente, tem menos a ganhar descumprindo o acordo do que em relação a um mercado composto por muitas firmas (em que uma firma pode atingir uma fatia de mercado proporcionalmente maior descumprindo o acordo $)^{21}$;

ii) barreiras à entrada: quanto menores às barreiras à entrada em uma indústria, mais difícil se torna sustentar o cartel, pois nesse caso os preços elevados decorrentes do

${ }^{19}$ GunNar Niels, Helen Jenkins e James Kavanagh, Economics for Competition Lawyers, Oxford University Press, 2011, p. 288.

${ }^{20}$ Como esclarece MASSIMO MOTTA, "only if a firm knows that a deviation will be identified quickly and that it will be punished (i.e., it will have to forego enough profits because of the market reaction of the cartel members) might it refrain from deviating, so that the collusive outcome will arise" (Competition Policy: Theory and Practice, New York, Cambridge University Press, 2004, p. 139).

${ }^{21}$ Massimo MotTA, Competition Policy: Theory and Practice, cit., pp. 142-143. 
cartel tenderão a atrair a entrada de novos competidores no mercado e desestabilizar o arranjo colusivo, o que não ocorrerá na presença de barreiras à entrada ${ }^{22}$;

iii) transparência do mercado: caso os preços praticados pelas firmas não sejam facilmente observáveis a partir dos dados de mercado, mais difícil se torna manter o cartel, uma vez que a capacidade de identificar e punir eventuais desvios é prejudicada $^{23}$;

iv) interação em vários mercados: caso as firmas envolvidas no cartel interajam em vários mercados, a capacidade de punir eventuais desvios tende a ser maior, pois as demais firmas podem retaliar aquele que descumpriu o acordo em todos os outros mercados em que atuam, o que reduz os incentivos para a defecção e aumenta a probabilidade de formação e manutenção de cartéis ${ }^{24}$; e

v) homogeneidade dos produtos: caso os produtos vendidos pelas firmas sejam homogêneos, mais fácil será para os membros do cartel estabelecerem o preço de venda em conjunto, pois não há necessidade de levar em consideração eventuais diferenciações entre os produtos vendidos pelas diferentes firmas ${ }^{25}$.

\footnotetext{
${ }^{22}$ A respeito das barreiras à entrada, CALIXTO SALOMÃo FILHO esclarece: "Dois tipos de barreiras devem ser analisadas. Em primeiro lugar, as chamadas barreiras naturais, decorrentes da própria conformação do mercado e do tamanho relativo de seus participantes. O segundo tipo, que é o que mais preocupa, é o das barreiras artificiais à entrada. São elas aquelas barreiras criadas por comportamentos ou omissões dos agentes econômicos, que tentam, com isso, criar um mercado cativo. No primeiro grupo incluem-se vários tipos de barreiras. As mais comumente citadas são a existência de grandes vantagens de escala, a diferenciação entre produtos, o grande investimento inicial de capital necessário e os chamados custos irrecuperáveis (sunk costs)" (Direito Concorrencial - As Estruturas, $3^{\mathrm{a}}$ ed., São Paulo, Saraiva, 2007, p. 187).

23 "More frequent price adjustments give firms the physical possibility to quickly retaliate when one market participant undercuts the others. But such deviation must first be identified by the other participants. As a result, collusion can be difficult to sustain when individual prices are not readily observable and cannot be easily inferred from readily available market data. This, in turn, supposes that some uncertainty affects the market: otherwise any deviation would be detected by the rivals, who would perceive a reduction in their market share. (...) what matters is not what is directly observed by the firms, but what information firms can infer from available market data. When the market is stable, inferring deviations from collusive conduct is easier and requires less market data than when the market is unstable" (MARC IVALDI, BRUNO JULLIEN, PATRICK Rey, PAUl SEABRIGHT e JeAn TIROLE, The Economics of Tacit Collusion - Final Report for DG Competition, Comissão Europeia, IDEI Toulouse, 2003, disponível em: <http://ec.europa.eu/competition/mergers/studies_reports/the_economics_of_tacit_collusion_en.pdf >. Acesso em: 29.ago.2014, p. 22).

${ }^{24}$ Massimo MotTA, Competition Policy: Theory and Practice, cit., pp. 148-149.

25 Embora a homogeneidade dos produtos seja comumente apontada pelas autoridades de defesa da concorrência como facilitadora da colusão, MASSIMO MOTTA esclarece que estudos sugerem que a formação de cartéis não necessariamente será mais fácil em mercados de produtos homogêneos (como gasolina) em
} 
Os fatores acima não são os únicos apontados pela literatura econômica, havendo outras condições que facilitam a formação e manutenção de cartéis ${ }^{26}$.

A simples presença dos fatores acima mencionados, contudo, não significa necessariamente que o mercado em questão será cartelizado. Por outro lado, a ausência de algumas das condições acima tampouco significa que a formação de cartel será impossível naquele mercado.

\subsubsection{Efeitos do cartel}

Como visto, a formação de um cartel visa a reproduzir uma situação de monopólio ${ }^{27}$. Nesse sentido, a exemplo das considerações feitas acima sobre o custo social do monopólio, os principais efeitos da prática de cartel são os seguintes:

i) a transferência de renda dos consumidores para os agentes cartelizados em decorrência do sobrepreço cobrado pelo cartel;

ii) redução da oferta no mercado, gerando o chamado "peso morto", correspondendo a um excedente que não é apropriado nem pelos cartelistas nem pelos consumidores, resultando em redução geral de bem-estar na sociedade; e

iii) danos colaterais que ultrapassam o "peso morto", correspondentes à redução de incentivos para que as empresas invistam na melhoria dos produtos, na redução de custos, dentre outros custos adicionais ${ }^{28}$.

relação a mercados em que há maior diferenciação (como cigarros, refrigerantes e águas minerais). (Competition Policy: Theory and Practice, cit., pp. 146-147).

${ }^{26}$ Dentre os demais fatores, pode-se mencionar a simetria entre os concorrentes, a frequência da interação dos concorrentes no mercado, a maturidade do mercado, a baixa elasticidade da demanda, dentre outros. A respeito, ver: Marc IVAldi, Bruno Jullien, Patrick Rey, Paul SEabright e Jean Tirole, The Economics of Tacit Collusion - Final Report for DG Competition, cit., pp. 11-57).

27 "By restricting output and raising prices, a cartel has the same negative effects as a monopoly: it distributes welfare from consumers to producers and reduces allocative, productive and dynamic efficiency in the market” (GUNNAR NIELS, HELEN JENKINS e JAMES KAVANAGH, Economics for Competition Lawyers, cit., p. 285).

${ }^{28}$ No julgamento do processo administrativo que investigou a prática de cartel no mercado de aços planos, o qual resultou na primeira condenação por cartel na história do Brasil, o CADE esclareceu que "o objetivo do cartel é elevar os preços ao consumidor, através da redução da concorrência, aproximando o resultado do 
Em razão dos inúmeros efeitos adversos causados pela prática de cartel, diversos estudos empíricos já foram realizados na tentativa de estimar o sobrepreço médio resultante dos cartéis ${ }^{29}$.

Um dos estudos mais citados, e que contou com a mais ampla base de dados até então já utilizada em análises semelhantes, foi realizado por JOHN CONNOR e ROBERT H. LANDE, que examinaram estimativas de sobrepreço referentes a cartéis verificados em 234 diferentes mercados desde o século XVIII. O estudo concluiu que os preços praticados em referidos mercados cartelizados foi na média $25 \%$ (vinte e cinco por cento) superior aos preços que teriam prevalecido em um mercado competitivo ${ }^{30}$.

Esses estudos explicam por que os cartéis são objeto de proibição em diversos ordenamentos jurídicos e justificam a preocupação das autoridades de defesa da concorrência em coibir a prática. No capítulo seguinte, serão analisadas as regras que tratam da proibição dos cartéis no ordenamento jurídico brasileiro.

mercado em termos de lucratividade ao que seria alcançado numa situação de monopólio. Além do efeito direto sobre o bem-estar econômico na forma da elevação compulsória de preços ao consumidor, o que caracteriza uma transferência de renda deste para o produtor, o cartel, ao reduzir a concorrência entre as empresas, reduz também a pressão para a melhoria da qualidade dos produtos, para a redução dos custos de produção e para a busca e introdução de inovações de um modo geral" (Processo Administrativo $n^{\circ}$ 08000.015337/1997-48, Conselheiro Relator Ruy Santacruz, julgado em 27.10.1999).

${ }^{29}$ Por exemplo, em estudo empreendido pela Organização para a Cooperação e Desenvolvimento Econômico (“OCDE”), estimou-se que os preços em um mercado cartelizado podem chegar a ser até 50\% (cinquenta por cento) mais elevados que os preços praticados em um mercado competitivo (OCDE, Hard Core Cartels, Paris, OECD Publications Service, 2000, p. 5).

30 "Cartel Overcharges and Optimal Cartel Fines" in American Bar Association, Issues in Competition Law and Policy, vol. 3, ABA Section of Competition Law, 2008, pp. 2209-2211. Os autores já haviam abordado o tema em: JoHn M. CONNOR e ROBERT H. LANDE, "The Size of Cartel Overcharges: Implications for U.S. and EU Fining Policies", in The Antitrust Bulletin, vol. 51, n. 4, Winter, 2006, pp. 983-1022. 


\section{A DISCIPLINA JURÍDICA DO CARTEL NO DIREITO BRASILEIRO}

O exame das regras atinentes à responsabilidade civil pela prática de cartel no Brasil deve ser precedido do estudo das diferentes normas que pró́bem a conduta no ordenamento jurídico brasileiro. Assim, após o exame do cartel sob a ótica econômica, empreendido no capítulo anterior, este capítulo terá o objetivo de examinar a disciplina jurídica dos cartéis no direito brasileiro.

Após breve histórico da evolução das normas concorrenciais no Brasil (item 2.1), serão estudadas as normas que preveem a responsabilização dos infratores pela prática de cartel na lei concorrencial (item 2.2) e na esfera penal (item 2.3).

\subsection{Evolução das normas de defesa da concorrência no Brasil}

O primeiro texto constitucional no Brasil a mencionar a liberdade econômica como um princípio constitucional foi a Constituição Federal de $1934^{31}$, cujo artigo 114 dispunha que "a ordem econômica deve ser organizada conforme os princípios da Justiça e as necessidades da vida nacional, de modo que possibilite a todos existência digna", estabelecendo ainda que "dentro desses limites, é garantida a liberdade econômica" ${ }^{, 32}$. Além disso, o artigo 117 do referido diploma constitucional estabelecia pela primeira vez no direito brasileiro que "a lei promoverá o fomento da economia popular".

A Constituição Federal de 1937, por sua vez, em seu artigo 141, também continha dispositivo prevendo o fomento da economia popular, dispondo ainda que "os crimes contra a economia popular são equiparados aos crimes graves contra o Estado,

\footnotetext{
${ }^{31}$ Como esclarece José Marcelo MARTins ProENÇA, na vigência das Constituições anteriores, de 1824 e 1891, imperava "a teoria do liberalismo econômico, consagrando o direito de propriedade em toda a sua plenitude. Referidas Constituições inserem-se no contexto ideológico do liberalismo político, ideológico e econômico, razão pela qual a plenitude do direito de propriedade tem como consectário o princípio da plena liberdade de iniciativa no mercado" (Concentração Empresarial..., cit., pp. 23-24).

${ }^{32}$ Como observa PaUla AndRea Forgioni, "o texto constitucional utiliza a expressão 'limites', ou seja, a liberdade dos agentes econômicos pode ser restringida para garantir a justiça e as necessidades da vida nacional. A liberdade econômica aparece, assim, em nosso ordenamento, intrinsecamente ligada à ideia de que ao Estado é facultado intervir na (v.g, art. 116) e sobre (v.g., art. 117) a economia, no resguardo de interesses maiores que aqueles dos agentes econômicos individualmente considerados" (Os Fundamentos do Antitruste, São Paulo, Revista dos Tribunais, 1998, pp. 100-101).
} 
devendo a lei cominar-lhes penas graves e prescrever-lhes processos e julgamentos adequados à sua pronta e segura punição”. Sob a vigência da Constituição Federal de 1937, foi editado o Decreto-Lei ${ }^{\circ}$ 869, de 18 de novembro de 1938, o qual previa os crimes contra a economia popular ${ }^{33}$.

Embora tais diplomas constitucionais e legais não tenham instituído um efetivo sistema de defesa da concorrência no Brasil, as regras sobre a proteção da economia popular são consideradas a gênese do direito antitruste no ordenamento jurídico brasileiro $^{34}$.

O primeiro diploma legal dispondo de maneira sistematizada sobre a repressão aos atos contrários à ordem econômica foi o Decreto-Lei $n^{0} 7.666$, de 22 de junho de 1945, de autoria do então Ministro do Trabalho do governo Getúlio Vargas, Agamennon Magalhães, que ficou conhecida como "Lei Malaia"35. O decreto previa um rol de "atos contrários à economia nacional", dentre eles a prática de "entendimentos, ajustes ou acordos" entre empresários "que tenham por efeito (...) elevar os preços dos respectivos produtos" (art. $1^{\circ}$, inc. I).

A Lei Malaia também criou a Comissão de Defesa da Concorrência, com poderes para decretar a intervenção (art. $4^{\circ}$ ) ou recomendar a desapropriação $\left(\operatorname{art.} 7^{\circ}\right)$ de empresas envolvidas em atos contrários à economia nacional, bem como de aprovar previamente, sob pena de nulidade, atos de fusão, incorporação e transformação de empresas em determinados setores (art. $8^{\circ}$ ), bem como outros atos que pudessem causar determinados efeitos considerados adversos à economia (e.g., "equilibrar a produção com o consumo", "regular o mercado", “estabilizar preços", dentre outros) (art. 11). No entanto, o período de vigência da Lei Malaia foi muito curto, tendo sido revogada após a queda do Presidente Getúlio Vargas, por meio do Decreto-Lei nº 8.167, de 9 de novembro de 1945.

\footnotetext{
${ }^{33}$ Dentre os crimes previstos, o art. $2^{\circ}$, inciso III previa a prática de "promover ou participar de consórcio, convênio, ajuste, aliança ou fusão de capitais, com o fim de impedir ou dificultar, para o efeito de aumento arbitrário de lucros, a concorrência em matéria de produção, transporte ou comércio".

${ }^{34}$ Benjamin ShIEBer, Abusos de Poder Econômico (Direito e Experiência Antitruste no Brasil e nos EUA), São Paulo, Revista dos Tribunais, 1966, p. 4.

35 PAULA ANDREA FORGIONI esclarece que "antes, a regulamentação da repressão ao abuso do poder econômico era efetuada por alguns diplomas legais, diluída, inclusive, pela falta de sistematização. Modificando completamente o rumo, a Lei Malaia disciplina a matéria de forma específica, sistemática, voltando-se de forma firme e direta contra o abuso do poder econômico" (Os Fundamentos do Antitruste, cit., p. 111).
} 
No ano seguinte, foi promulgada a Constituição Federal de 1946, a qual, pela primeira vez, dispunha expressamente sobre a repressão ao abuso do poder econômico. O artigo 148 previa que "a lei reprimirá toda e qualquer forma de abuso do poder econômico, inclusive as uniões ou agrupamentos de empresas individuais ou sociais, seja qual for a sua natureza, que tenham por fim dominar os mercados nacionais, eliminar a concorrência e aumentar arbitrariamente os lucros".

A regulamentação do referido dispositivo constitucional somente ocorreu com a edição da Lei 4.137, de 10 de setembro de 1962. Referida lei continha rol de condutas consideradas como abuso de poder econômico, dentre elas a dominação de mercados por meio de "ajuste ou acordo entre empresas" (art. $2^{\circ}$, inc. I, alínea a), tendo criado o CADE, órgão então vinculado à Presidência do Conselho de Ministros com a incumbência de apurar e reprimir os abusos do poder econômico (art. $8^{\circ}$ ). É interessante notar que referida lei já continha regra expressa dispondo que "poderá a parte lesada por abuso de poder econômico exigir do órgão e seus administradores ou quaisquer responsáveis, solidariamente, a satisfação das perdas e danos na forma do direito comum" (art. 20).

Embora a Lei 4.137/62 seja considerada "a primeira lei antitruste brasileira em sentido próprio" 36 e tenha tido vigência formal por mais de três décadas ${ }^{37}$ - tendo sido recepcionada pelas Constituições Federais de 1967, 1969 e 1988 - a lei acabou por ter pouca aplicação prática, não tendo instituído um efetivo regime de proteção à concorrência no Brasil ${ }^{38}$.

A Constituição Federal de 1988 dedica um título inteiro à disciplina da ordem econômica e financeira. O artigo 170 dispõe que a ordem econômica é "fundada na valorização do trabalho humano e na livre iniciativa" e erige a livre concorrência como

\footnotetext{
${ }^{36}$ Calixto Salomão FILHO, Direito Concorrencial - As Estruturas, cit., p. 82.

${ }^{37}$ A Lei 4.137/62 foi expressamente revogada pelo art. 92 da Lei 8.884/1994.

38 "Nesse período o CADE permaneceu praticamente inativo, com poucas e parcas realizações, tendo se prestado muito mais a instrumento do Estado em ações demagógicas de combate a crimes contra a economia popular e contra o desabastecimento de determinados produtos essenciais (em razão dos constantes tabelamentos de preços) do que efetivamente a defender a livre concorrência" (ARMANDO CASTELAR PinheIro e JaIRo SADDI, Direito, Economia e Mercados, Rio de Janeiro, Editora Campus, 2005, p. 382).
} 
princípio fundamental da ordem econômica, ao lado de outros princípios de igual hierarquia, como a função social da propriedade e a defesa dos consumidores ${ }^{39}$.

O artigo 173, $\S 4^{\circ}$ da Constituição Federal de 1988, por sua vez, constitui o fundamento do direito concorrencial no ordenamento jurídico brasileiro ${ }^{40}$ e prevê que "a lei reprimirá o abuso do poder econômico que vise à dominação de mercados, à eliminação da concorrência e ao aumento arbitrário de lucros" ${ }^{41}$.

Sob a vigência da Constituição de 1988, foi inicialmente promulgada a Lei $\mathrm{n}^{\mathrm{o}} 8.158$, de 8 de janeiro de 1991, que tinha o objetivo de reestruturar a defesa da concorrência no Brasil, mas que teve vigência curta e pouca efetividade prática ${ }^{42}$.

Foi somente a partir da promulgação da Lei 8.884/1994 que se instituiu um verdadeiro regime de proteção à livre concorrência no Brasil. A Lei 8.884/1994 estruturou o Sistema Brasileiro de Defesa da Concorrência (“SBDC"), formado por: (i) CADE, que foi transformado em autarquia, com poderes para aprovar operações de concentração empresarial e decidir sobre a prática de infrações à ordem econômica (art. $7^{\circ}$ ); (ii) Secretaria de Direito Econômico do Ministério da Justiça (“SDE”), cuja principal atribuição era iniciar e instruir os processos administrativos para apuração de infrações à ordem econômica (art. 14); e (iii) a Secretaria de Acompanhamento Econômico do

39 “Art. 170. A ordem econômica, fundada na valorização do trabalho humano e na livre iniciativa, tem por fim assegurar a todos existência digna, conforme os ditames da justiça social, observados os seguintes princípios: (...) IV - livre concorrência”. Sobre o conceito de ordem econômica na Constituição Federal, vide: EROS Roberto GraU, A Ordem Econômica na Constituição de 1988 (Interpretação e Crítica), $10^{\mathrm{a}}$ ed., São Paulo, Malheiros, 2005.

${ }^{40}$ De acordo com CAliXto SAlOMÃo FilHo, referido dispositivo constitui a "pedra fundamental do direito antitruste" (Direito Concorrencial - As Condutas, cit., p. 106). Sobre as bases constitucionais da defesa da concorrência no Brasil, veja-se também: José MARCElo Martins ProEnçA, Concentração Empresarial..., cit., pp. 1-22.

${ }^{41}$ Interpretando o princípio constitucional da livre concorrência à luz do art. $173, \S 4^{\circ}$, EROS ROBERTO GRAU sustenta: "Deveras, não há oposição entre o princípio da livre concorrência e aquele que se oculta sob a norma do $\$ 4^{\circ}$ do art. 173 do texto constitucional, princípio latente, que se expressa como princípio da repressão aos abusos do poder econômico e, em verdade - porque dele é fragmento - compõe-se no primeiro" (A Ordem Econômica na Constituição de 1988..., cit., p. 209).

${ }^{42}$ PAULA ANDREA FORGIONI narra que "o panorama do direito antitruste brasileiro parecia que seria alterado com a promulgação da Lei 8.158, de 8 de janeiro de 1991. (...) Esse breve período de euforia, quando parecia que, a final, teríamos uma legislação antitruste aplicada efetivamente como um instrumento de política econômica, pouco durou aos olhos do público. Com o novo governo instalado em 1992, não obstante o CADE continue sua atuação destinada a coibir o abuso do poder econômico, esta acaba sendo sufocada, na imprensa, pelo triste papel que a Lei Antitruste passa a desempenhar no contexto econômico brasileiro: instrumento de ameaça de retaliação por parte do governo federal contra determinados setores da economia" (Os Fundamentos do Antitruste, cit., p. 133). 
Ministério da Fazenda ("SEAE”), que tinha por atribuição principal instruir os atos de concentração para análise de operações de concentração empresarial (art. 54, $\S \S 4^{\circ}$ e $6^{\circ}$ ).

A Lei 8.884/94 instituiu um efetivo regime de controle de concentrações empresariais (art. 54) e, em matéria de condutas, estabeleceu nos artigos 20 e 21 a disciplina das infrações à ordem econômica, prevendo, no artigo 23, a aplicação das seguintes sanções aos infratores: (i) multa de 1\% (um por cento) a 30\% (trinta por cento) do faturamento bruto das empresas condenadas pela prática de infração à ordem econômica (art. 23, inciso I); e (ii) multa aos administradores entre $10 \%$ (dez por cento) a $50 \%$ (cinquenta por cento) daquela aplicada à empresa (art. 23, inciso II) ${ }^{43}$. O artigo 29 da Lei 8.884/1994 assegurava aos prejudicados pela prática de infrações à ordem econômica o direito de "receber indenização pelas perdas e danos sofridos, independentemente do processo administrativo, que não será suspenso em virtude do ajuizamento da ação".

Finalmente, em 30 de novembro de 2011, foi sancionada a atual lei antitruste (Lei 12.529/2011). A lei reestruturou o SBDC, concentrando a tarefa de aplicação da lei concorrencial em um único órgão, o CADE, que passou a ser composto: (i) pelo Tribunal Administrativo, formado por seis Conselheiros e um Presidente, cujas principais atribuições são decidir sobre a existência de infração à ordem econômica (art. $9^{\circ}$, inc. II) e julgar os processos administrativos para imposição de sanções (art. $9^{\circ}$, inc. III), bem como decidir os atos de concentração submetidos pela Superintendência-Geral (art. $9^{\circ}$, inc. X); (ii) pela Superintendência-Geral, cujas principais atribuições são instaurar e instruir os processos administrativos para investigação de infrações à ordem econômica (art. 13, inc. V), bem como instruir e aprovar os atos de concentração, ou, quando entender que o ato de concentração deva ser rejeitado ou aprovado com restrições, submetê-lo ao Tribunal Administrativo (art. 13, inc. XII); e (iii) o Departamento de Estudos Econômicos, com a atribuição de elaborar estudos e pareceres econômicos, de ofício ou por solicitação do Plenário, do Presidente, do Conselheiro-Relator ou do Superintendente-Geral (art. 17).

\footnotetext{
${ }^{43}$ A Lei 8.884/94 também previa multa de 6.000 (seis mil) a 6.000 .000 (seis milhões) de Unidades Fiscais de Referência ("UFIR") para as "demais pessoas físicas ou jurídicas de direito público ou privado, bem como quaisquer associações de entidades ou pessoas constituídas de fato ou de direito, ainda que temporariamente, com ou sem personalidade jurídica, que não exerçam atividade empresarial" (art. 23, inciso III), além de penalidades não pecuniárias aos infratores, como a proibição de contratar com instituições financeiras oficiais ou participar de licitações (art. 24).
} 
Em matéria de controle de estruturas, a Lei 12.529/2011 instituiu o regime de controle prévio de atos de concentração (art. 88, $\S 2^{\circ}$ ) e alterou os critérios de notificação de operações de concentração econômica (art. 88, inc. I e II e art. 90). Com relação ao controle de condutas, a lei manteve praticamente inalterada a definição de infrações à ordem econômica (art. 36) e o rol exemplificativo de condutas anticompetitivas (art. 36, $\S 3^{\circ}$ ), embora tenha reduzido os percentuais das penalidades máximas aplicáveis aos infratores (art. 37), conforme será examinado no tópico seguinte. A Lei 12.529/2011 contém ainda dispositivo praticamente idêntico ao da Lei 8.884/1994 assegurando a indenização por perdas e danos aos prejudicados por infrações à ordem econômica (art. 47), o qual será examinado no capítulo 5.

\subsection{O cartel como infração à ordem econômica}

\subsubsection{A disciplina das infrações à ordem econômica na Lei 12.529/2011}

O artigo 36 da Lei 12.529/2011 define as práticas caracterizadas como infração à ordem econômica. O artigo 37 do mesmo diploma legal, por sua vez, dispõe sobre as penalidades na esfera administrativa. Em relação à Lei 8.884/1994, a lei atual promoveu uma redução dos percentuais máximos das penalidades aplicadas às empresas e administradores, bem como alteração da base de cálculo das multas aplicadas às empresas. As penalidades previstas na Lei 12.529/2011 pela prática de infração à ordem econômica são as seguintes: (i) multa de $0,1 \%$ (um décimo por cento) a $20 \%$ (vinte por cento) do faturamento bruto da empresa, grupo ou conglomerado econômico, obtido no ano anterior à instauração do processo administrativo no ramo de atividade empresarial em que ocorreu a infração, a qual nunca será inferior à vantagem auferida, quando possível sua estimação (art. 37, inc. I); (ii) no caso de administrador, multa de $1 \%$ (um por cento) a $20 \%$ (vinte por cento) da multa aplicada à empresa (art. 37, inc. III); e (iii) no caso das demais pessoas físicas, jurídicas, associações ou entidades que não exerçam atividade empresarial envolvidas na infração, multa de 50.000,00 (cinquenta mil reais) a R \$ 2.000.000.000,00 (dois bilhões de reais) às (art. 37 , inc. II $)^{44}$.

\footnotetext{
${ }^{44}$ Veja-se o inteiro teor do art. 37 da Lei 12.529/2011: “Art. 37. A prática de infração da ordem econômica sujeita os responsáveis às seguintes penas: I - no caso de empresa, multa de $0,1 \%$ (um décimo por cento) a $20 \%$ (vinte por cento) do valor do faturamento bruto da empresa, grupo ou conglomerado obtido, no último exercício anterior à instauração do processo administrativo, no ramo de atividade empresarial em que ocorreu a infração, a qual nunca será inferior à vantagem auferida, quando for possível sua estimação; II - no caso das
} 
A redução nos percentuais das multas aplicáveis - no caso da empresa, de $30 \%$ (trinta por cento) para 20\% (vinte por cento) do faturamento -, é objeto de crítica na doutrina, argumentando-se que tal redução caminha na contramão da tendência internacional de maior rigor nas punições (em especial em casos de cartel) e pelo fato de que, em determinados casos, as multas serão insuficientes para coibir adequadamente as práticas anticompetitivas ${ }^{45}$.

A Lei 12.529/2011 também prevê, no artigo 38, penalidades não pecuniárias aos envolvidos na prática de infração à ordem econômica, quais sejam: (i) a publicação em meia página de jornal do extrato da decisão condenatória do CADE às expensas do infrator; (ii) a proibição de contratar com instituições financeiras oficiais e participar de licitações públicas; (iii) a inscrição do infrator no Cadastro Nacional de Defesa do Consumidor; (iv) a recomendação aos órgãos públicos para que seja concedida licença compulsória de direitos de propriedade intelectual, não seja concedido parcelamento de

demais pessoas físicas ou jurídicas de direito público ou privado, bem como quaisquer associações de entidades ou pessoas constituídas de fato ou de direito, ainda que temporariamente, com ou sem personalidade jurídica, que não exerçam atividade empresarial, não sendo possível utilizar-se o critério do valor do faturamento bruto, a multa será entre $\mathrm{R} \$ 50.000,00$ (cinquenta mil reais) e $\mathrm{R} \$ 2.000 .000 .000,00$ (dois bilhões de reais); III - no caso de administrador, direta ou indiretamente responsável pela infração cometida, quando comprovada a sua culpa ou dolo, multa de $1 \%$ (um por cento) a $20 \%$ (vinte por cento) daquela aplicada à empresa, no caso previsto no inciso I do caput deste artigo, ou às pessoas jurídicas ou entidades, nos casos previstos no inciso II do caput deste artigo".

${ }^{45}$ Nesse sentido, em estudo coordenado por JOSÉ MARCELO MARTINS PROENÇA sobre o projeto de lei que resultou na Lei 12.529/2011, concluiu-se o seguinte: "O capítulo referente às penas sofreu diversas alterações pontuais na nova lei concorrencial. Entre pequenos avanços e retrocessos significativos, a maior preocupação remanescente se dá com a possibilidade de um sistema de multas sub-dissuasório. Caso seja mantida a redação original do Projeto de Lei, ou seja, mantendo-se a base de cálculo como o mercado relevante da infração, em muitos casos, o CADE ver-se-á de mãos atadas no momento da quantificação, impondo multas consideradas 'ridículas' pelo ex-Conselheiro Leopoldino Fonseca, uma vez que equivalentes aos lucros auferidos pelo infrator e, portanto, ineficazes. Esse risco só poderia ser resolvido com uma nova alteração legislativa. É necessária a inclusão de um novo dispositivo no artigo 37 que preveja ou uma multa de até duas ou três vezes valor do lucro auferido, como previsto na legislação antitruste americana ou na lei da CVM, por exemplo. Caso o trecho da Emenda $\mathrm{n}^{\circ} 21$ sobre o assunto seja aprovada, alterando a expressão "mercado relevante" por "ramo de atividade empresarial", o tribunal administrativo terá a prerrogativa de aplicar a multa sobre uma base de cálculo maior, obtendo sanções superiores aos ganhos da empresa no mercado relevante. Dependendo da forma como essa expressão fosse aplicada na jurisprudência, ela poderia atenuar substancialmente o problema anteriormente descrito. Em ambas as alterações, no entanto, vale frisar que o Brasil está atenuando significantemente suas sanções no âmbito do antitruste, caminhando na contramão da tendência global de crescente severidade na punição de tais condutas" (A Reforma da Lei da Concorrência Lei $n^{o}$ 8.884/94, $1^{\text {o }}$ Congresso Brasileiro de Direito Comercial, 2011, disponível em: <http://www.congressodireitocomercial.org.br/2011/images/stories/pdfs/gep12.pdf>. Acesso em: 28.nov.2014, pp. 67-68). Em sentido semelhante, ROBERTO DOMINGOS TAUFICK sustenta que "o efeito da alteração pode ser indesejado. Segundo estudos da OCDE, cartéis provocam sobrepreço médio de 20\%-30\%, de tal sorte que a punição, especialmente nos cartéis internacionais, pode ser insuficiente para compensar a vantagem auferida e, ainda, punir os infratores" (Nova Lei Antitruste Brasileira - A Lei 12.529/2011 Comentada e a Análise Prévia no Direito da Concorrência, Rio de Janeiro, Forense, 2012, p. 262). 
tributos federais e sejam cancelados incentivos fiscais ou subsídios públicos; (v) a cisão de sociedade, transferência de controle societário, venda de ativos ou cessação parcial da atividade; (vi) a proibição de exercer o comércio pelo prazo de cinco anos; e (vii) qualquer ato ou providência necessários para eliminação dos potenciais efeitos nocivos à concorrência $^{46}$.

Com relação à definição do ilícito, o caput do artigo 36 da Lei 12.529/2011, que reproduz o artigo 20 da lei concorrencial anterior, dispõe que constituem infração à ordem econômica, independentemente de culpa, os atos que tenham por objeto ou possam produzir os seguintes efeitos, ainda que não sejam alcançados: (i) limitar, falsear ou prejudicar a concorrência ou a livre iniciativa, (ii) dominar mercado relevante de bens ou serviços, (iii) aumentar arbitrariamente os lucros, e (iv) exercer de forma abusiva posição dominante $^{47}$. O $\S 3^{\circ}$ do artigo 36 , por sua vez, apresenta rol exemplificativo de condutas que, na medida em que caracterizem as hipóteses do caput, configuram infração à ordem econômica.

Como se percebe, os ilícitos concorrenciais são definidos na lei antitruste por meio de fórmulas gerais vinculadas à potencialidade de produção de determinados efeitos anticompetitivos (artigo 37, caput e respectivos incisos), prevendo-se, em outro

\footnotetext{
46 “Art. 38. Sem prejuízo das penas cominadas no art. 37 desta Lei, quando assim exigir a gravidade dos fatos ou o interesse público geral, poderão ser impostas as seguintes penas, isolada ou cumulativamente: I - a publicação, em meia página e a expensas do infrator, em jornal indicado na decisão, de extrato da decisão condenatória, por 2 (dois) dias seguidos, de 1 (uma) a 3 (três) semanas consecutivas; II - a proibição de contratar com instituições financeiras oficiais e participar de licitação tendo por objeto aquisições, alienações, realização de obras e serviços, concessão de serviços públicos, na administração pública federal, estadual, municipal e do Distrito Federal, bem como em entidades da administração indireta, por prazo não inferior a 5 (cinco) anos; III - a inscrição do infrator no Cadastro Nacional de Defesa do Consumidor; IV - a recomendação aos órgãos públicos competentes para que: a) seja concedida licença compulsória de direito de propriedade intelectual de titularidade do infrator, quando a infração estiver relacionada ao uso desse direito; b) não seja concedido ao infrator parcelamento de tributos federais por ele devidos ou para que sejam cancelados, no todo ou em parte, incentivos fiscais ou subsídios públicos; V - a cisão de sociedade, transferência de controle societário, venda de ativos ou cessação parcial de atividade; VI - a proibição de exercer o comércio em nome próprio ou como representante de pessoa jurídica, pelo prazo de até 5 (cinco) anos; e VII - qualquer outro ato ou providência necessários para a eliminação dos efeitos nocivos à ordem econômica".

47 “Art. 36. Constituem infração da ordem econômica, independentemente de culpa, os atos sob qualquer forma manifestados, que tenham por objeto ou possam produzir os seguintes efeitos, ainda que não sejam alcançados: I - limitar, falsear ou de qualquer forma prejudicar a livre concorrência ou a livre iniciativa; II dominar mercado relevante de bens ou serviços; III - aumentar arbitrariamente os lucros; e IV - exercer de forma abusiva posição dominante".
} 
dispositivo $\left(\S 3^{\circ}\right)$ rol meramente exemplificativo de condutas concretas que podem caracterizar infração à ordem econômica ${ }^{48}$.

Um traço importante do ilícito antitruste, tal como definido na lei concorrencial brasileira, é o fato de a infração à ordem econômica se caracterizar "independentemente de culpa". Isso quer dizer que, caso determinado ato tenha aptidão objetiva para produzir os efeitos anticompetitivos descritos nos incisos do art. 36, não há necessidade de perquirir a intenção subjetiva do agente ou avaliar se sua conduta foi negligente ou imprudente para que fique caracterizada a infração à ordem econômica.

\section{De acordo com TÉRCIO SAMPAIO FERRAZ JÚNIOR ${ }^{49}$ :}

"A ilicitude concorrencial administrativa está na conjugação da prática (ainda que lícita) com o efeito, independentemente da intenção do agente (daí a dicção normativa tanto na lei anterior como na atual: 'independentemente de culpa', assinalando, destarte, a infração como um desvio de finalidade no uso - ainda que por meio de práticas normais - do poder econômico). Como no dolo eventual, o risco é um fator a ser levado em conta pelo agente, mormente quando tem, no mercado relevante, posição dominante. Nesses casos a natureza da culpa tem antes um sentido social, mais próximo do abuso de direito nos termos do Código Civil e do desvio de poder do Direito Administrativo".

A demonstração de culpa ou dolo para caracterização de infração à ordem econômica somente é necessária no caso de responsabilização dos administradores, nos termos do art. 37, inc. III, que prevê expressamente que a responsabilização do administrador somente ocorrerá "quando comprovada a sua culpa ou dolo"

\footnotetext{
${ }^{48}$ CALIXTO SALOMÃo FILHO, escrevendo sobre regra idêntica prevista na lei concorrencial anterior, esclarece o seguinte: "Na sistemática da lei os ilícitos são definidos, através de fórmulas gerais, em um dispositivo (art. 20), deixando-se para outra regra (art. 21) a concretização, a título meramente exemplificativo, das fórmulas gerais antes descritas." (Direito Concorrencial - As Condutas, cit., p. 18). PAULA ANDREA FORGIONI, por sua vez, comparando o sistema da Lei $\mathrm{n}^{\circ}$ 8.884/1994 com os sistemas norte-americano e europeu, escreve: "No que tange à tipificação das práticas antitruste, a lei brasileira é bastante peculiar, embora em muitos aspectos possa ser comparada a sistemas estrangeiros. (...) o sistema da lei brasileira é um sistema híbrido, que aproveita o europeu no que tange à caracterização do ilícito pelo objeto ou efeito, mas supera tanto esta tradição quanto aquela norte-americana no que tange à tipificação dos atos. (...) Para que seja considerado contrário à ordem econômica, basta que o ato determine a incidência do art. 20, ou seja, tenha por objeto ou possa produzir um dentre os seguintes efeitos: (...)" (Os Fundamentos do Antitruste, cit., pp. 136-138).

49 "Direito da Concorrência e Enforcement Privado na Legislação Brasileira", in Revista de Defesa da Concorrência, $\mathrm{n}^{\circ} 2$, novembro de 2013, p. 14.

${ }^{50}$ Sobre referido dispositivo, LEONOR CORDOVIL escreve: "De acordo com ambas as leis [Lei 8.884/94 e Lei 12.529/2011], é indiferente, na apuração de prática de uma infração à ordem econômica, a existência de culpa ou dolo. É a responsabilidade objetiva prevista expressamente pela legislação, com a única exceção observada à prática de infração pelo administrador, quando deve ser verificada, no mínimo, a existência de
} 
A exigência expressa de culpa ou dolo para responsabilização dos administradores não constava da Lei 8.884/1994 e foi introduzida pela Lei 12.529/11. Note-se que tal exigência foi prevista apenas para os "administradores" (art. 37, inc. III) e, sem qualquer razão aparente, não foi prevista com relação às "demais pessoas físicas" passíveis de punição na esfera administrativa (art. 37, inc. II), muito embora seja possível defender, com base na aplicação por analogia, que a responsabilização de tais pessoas físicas também pressupõe a demonstração de culpa ou dolo ${ }^{51}$.

\title{
2.2.2 A caracterização do cartel como infração à ordem econômica
}

Dentre as condutas anticompetitivas exemplificadas no $\S 3^{\circ}$ da Lei 12.529/2011, o inciso I prevê a prática de cartel, definida como acordo, combinação, manipulação ou ajuste entre concorrentes com o objetivo de fixar variáveis concorrenciais, tais como preços, quantidades, divisão de mercados e condições em licitações. Veja-se o teor do dispositivo:

\begin{abstract}
“Art. 36. (...) $\S 3^{\circ}$ As seguintes condutas, além de outras, na medida em que configurem hipótese prevista no caput deste artigo e seus incisos, caracterizam infração da ordem econômica: "I - acordar, combinar, manipular ou ajustar com concorrente, sob qualquer forma: a) os preços de bens ou serviços ofertados individualmente; b) a produção ou a comercialização de uma quantidade restrita ou limitada de bens ou a prestação de um número, volume ou frequência restrita ou limitada de serviços; c) a divisão de partes ou segmentos de um mercado atual ou potencial de bens ou serviços, mediante, dentre outros, a distribuição de clientes, fornecedores, regiões ou períodos; d) preços, condições, vantagens ou abstenção em licitação pública;"
\end{abstract}

De modo geral, a caracterização da prática de cartel exige a presença concomitante de dois requisitos: (i) existência de acordo, expresso ou tácito, entre concorrentes com o objetivo levar a uma situação de dominação do mercado; e (ii) aptidão

culpa (art. 37, III)" (LeONOR Cordovil, Vinícius MARques de CARVALHo, Vicente BaGnoli e Eduardo CAMINATI ANDERS, Nova Lei de Defesa da Concorrência Comentada - Lei 12.529, de 30 de novembro de 2011, São Paulo, Revista dos Tribunais, 2011, p. 101).

${ }^{51}$ Nesse sentido, veja-se o posicionamento de ANA PAula MARTinEZ: "A Lei 12.529/2011 não previu expressamente o mesmo requisito de exigência de dolo ou culpa no caso das 'demais pessoas físicas', referidas no artigo 37, II, mas decorre do nosso próprio sistema jurídico que elas somente poderão ser responsabilizadas se presente dolo ou culpa como elemento subjetivo da conduta" (Repressão a Cartéis: Interface entre Direito Administrativo e Direito Penal, São Paulo, Singular, 2013, p. 145). 
objetiva do acordo para produzir os efeitos anticompetitivos visados, o que dependerá do poder conjunto dos agentes em razão das condições estruturais do mercado.

Desse modo, diante da estrutura do ilícito concorrencial examinada acima, não basta a simples existência de acordo entre concorrentes, sendo necessário demonstrar sua potencialidade de acarretar quaisquer dos efeitos anticompetitivos previstos na lei. A respeito, confira-se a lição de CALIXTO SALOMÃo FILHO ${ }^{52-53}$ :

"Em matéria de condutas, a tradução do valor concorrência é dada por um binômio: é necessário um objetivo anticoncorrencial e é fundamental que esse objetivo seja realizável. Esse binômio é a tradução jurídica do que os economistas costuma chamar de racionalidade econômica. Note-se, de resto que estes são exatamente os requisitos estabelecidos no artigo 20, caput da lei concorrencial (objetivo e efeito potencial). No assunto que ora nos interessa, a cooperação econômica, é necessário determinar aqueles comportamentos que só fazem sentido, i.e., só são racionais, se baseados em uma estratégia cooperativa. Ou então, compreendidos de outra forma, aqueles comportamentos que supostamente serão direcionados a um fim cooperativo realizável capaz de levar à dominação do mercado. É, portanto, o objetivo realizável de dominar o mercado através de ajuste entre empresas fator chave para caracterização da antijuridicidade. Isto significa, de um lado, que é necessário que existam condições estruturais que permitam aos participantes do acordo assegurar a dominação. Assim, os tradicionais critérios econômicos do reduzido número de participantes e da existência de barreiras à entrada. A ligação desse requisito ao valor concorrência é direta. O valor jurídico a ser protegido não é a inexistência de contato ou mesmo de acordo entre concorrentes. $\mathrm{O}$ valor protegido é a concorrência, i.e. a existência de alternativas para o consumidor. Desse modo, apenas o acordo que possa levar à dominação é juridicamente relevante".

A sistemática adotada no direito brasileiro difere, por exemplo, do tratamento dado à matéria pela jurisprudência e doutrina dos Estados Unidos, em que os cartéis são considerados ilícitos "per se", dispensando-se o exame das características estruturais do mercado para que a prática seja considerada ilícita ${ }^{54}$.

\footnotetext{
52 “Apontamentos para Formulação de uma Teoria Jurídica dos Cartéis", in Regulação e Concorrência (Estudos e Pareceres), São Paulo, Malheiros, 2002, pp. 201-203.

53 No mesmo sentido, PAUla ANDREA FORGIONI esclarece que "trazendo a tradicional definição do cartel para o contexto da Lei 8.884, de 1994, devemos concluir que se um acordo não restringe a livre concorrência ou não acarreta a incidência de qualquer inciso do art. 20 da Lei 8.884, não se há que falar na existência de cartel, pois a associação não traz, em si, qualquer efeito anticompetitivo que interesse à proteção da ordem econômica. (...) É perfeitamente possível, pois, dentro do sistema estabelecido pela Lei 8.884, de 1994, que se verifique algum acordo previsto no art. 21 sem que haja infração à ordem econômica. Basta, para tanto, que não se dê a incidência de qualquer dos incisos do art. 20" (Os Fundamentos do Antitruste..., cit., pp. 327 328).

${ }^{54}$ ROBERT H. BORK, examinando o tratamento da matéria no direito norte-americano, defende a manutenção da regra de ilicitude "per se" de cartéis, fazendo a ressalva de que tal tratamento deveria ser dispensado
} 
A doutrina costuma diferenciar entre duas modalidades distintas de cartel: meio oral ou escrito, combinam de limitar a competição entre si, fixando preços, quantidades, dividindo mercados, etc. ${ }^{55}$; e

ii) acordo tácitos, nos quais não há acordo expresso e combinação entre os concorrentes ocorre por outros mecanismos de transmissão de informações, tais como anúncios de aumentos de preços por meio da imprensa, por exemplo ${ }^{56}$.

De modo semelhante, costuma-se também distinguir entre o chamado cartel difuso e cartel hardcore (ou cartel clássico). Enquanto o primeiro consiste na simples troca de informações entre os concorrentes ${ }^{57}$, o segundo envolve um acordo entre os concorrentes para fixar as principais variáveis concorrenciais ${ }^{58-59}$.

apenas aos chamados acordos puros ("naked agreements"), ou seja, acordos cujo objeto precípuo seja a fixação de preços ou divisão de mercados, no qual a restrição não seja acessória ( "ancillary”) a um acordo principal que possa gerar efeitos positivos sob a perspectiva concorrencial. Nas palavras do autor: "The law's oldest and, properly qualified, most valuable rule states that it is illegal per se for competitors to agree to limit rivalry among themselves. (...) The rule should be restated so that it is illegal per se to fix prices or divide markets (or to eliminate rivalry in any other way) only when the restraint is 'naked' - that is, only when the agreement is not ancillary to cooperative productive activity engaged in by the agreeing parties" (The Antitrust Paradox - A Policy at War With Itself, New York, Free Press, 1993, p. 263).

${ }^{55}$ CALIXTO SALOMÃo FILHO, escrevendo sobre os acordos expressos, critica a tendência das autoridades de limitarem as investigações à busca de provas diretas do acordo entre concorrentes: "Note-se, no entanto, que essa busca de provas, natural e necessária, pode levar a problemas jurídicos de monta. Recentemente, essa tem sido a tendência da prática brasileira. Investigações de cartéis tem-se resumido à busca de prova de acordo. Em função disso, a disciplina só se enfraquece. De uma lado, a fattispecie ganha definição formal e não-sistemática. Torna-se necessariamente restritiva, pois passa a englobar apenas as hipóteses de acordo expresso e formalizado. De outro, para compensar essa restrição, a tendência é e tem sido ampliar enormemente aquilo que pode ser considerado prova de acordo. Sequer são necessários indícios. Bastam, com frequência, suposições. Com isso, de um lado, direitos individuais diversos possam a ser violados e, de outro, as investigações são, com frequência, infrutíferas" (Direito Concorrencial - As Condutas, cit., pp. 265-266)

${ }^{56}$ IVO TEIXEIRA GICO JÚNIOR, escrevendo sobre os acordos tácitos, identifica a existência de uma pluralidade de terminologias na doutrina jurídica e econômica para a descrição do fenômeno (e.g., colusão tácita, paralelismo consciente, interdependência oligopolística, comportamento paralelo intencional, dentre outros), o que, na visão do autor, dificulta a apreciação do problema (Cartel: Teoria Unificada da Colusão, São Paulo, Lex Editora, 2007, pp. 341-345).

${ }^{57}$ Ana PAUla Martinez, Repressão a Cartéis..., cit., p. 43.

${ }^{58}$ Veja-se a definição da OCDE para os chamados cartéis hardcore: “'Hard core cartels' are anticompetitive agreements by competitors to fix prices, restrict output, submit collusive tenders, or divide or share markets" (OCDE, Hard Core Cartels, cit., p. 6).

${ }^{59}$ De acordo com posicionamento já manifestado pelo CADE, o cartel clássico seria aquele com elevado grau de institucionalização entre os seus membros ("reuniões periódicas, manuais de operação, princípios de 
Além das classificações acima, também se costuma distinguir entre cartéis nacionais (que envolvem apenas o mercado doméstico) e internacionais (envolvendo ou produzindo efeitos em mais de um país), cartéis de compra (acordo colusivo entre adquirentes de produtos ou serviços) ou de venda (cartéis entre vendedores de produtos ou serviços), bem como entre cartéis de importação (modalidade de cartel de compra, relacionado a produtos ou serviços importados) ou de exportação (modalidade de cartel de venda, relacionado a produtos para exportação) ${ }^{60}$.

\subsubsection{Jurisprudência do CADE em matéria de cartel}

No âmbito da análise da disciplina jurídica do cartel na lei concorrencial, convém examinar a jurisprudência do CADE em matéria de cartel, com ênfase nos critérios adotados para caracterização e demonstração da prática ilícita.

Em diversos julgados, em especial no início de vigência da Lei 8.884/94, o CADE decidiu pela condenação com base em indícios de cartel. De fato, a obtenção de provas diretas da existência de cartéis historicamente tem sido uma das maiores dificuldades enfrentadas pelas autoridades de defesa da concorrência, tanto no Brasil como em outros países ${ }^{61}$. A explicação é simples: tendo em vista a ilicitude da prática, os membros de um cartel não costumam formalizar ou documentar o acordo, o que dificulta a obtenção de provas sobre a sua existência.

Para lidar com essas dificuldades, a jurisprudência do CADE fixou o entendimento de que não são imprescindíveis provas diretas da existência de acordo entre os concorrentes para que o cartel seja considerado provado, sendo suficiente a presença de indícios da prática ilícita ${ }^{62}$.

comportamento etc"), enquanto o cartel difuso teria "caráter eventual e não institucionalizado" (voto do Conselheiro Relator Luiz Carlos Delorme Prado no Processo Administrativo no 08012.002127/2002-14, julgado em 13.07.2005).

${ }^{60}$ Ana PAUla Martinez, Repressão a Cartéis..., cit., pp. 43-47.

${ }^{61}$ A dificuldade em obter provas diretas da formação de cartel já foi reconhecida pela jurisprudência norteamericana em diversas oportunidades. Confira-se: "[o]nly ralely will there be direct evidence of an express agreement" (Local Union No 189. Amalgamated Meat Cutters v. Jewel Tea Co., 381 U.S. 676, 720, 1965); "By its nature conspiracy is conceived and carried out clandestinely, and direct evidence of the crime is rarely available" (United States v. Washington, 586 F.2d 1147, 1153, 7th Cir., 1978).

62 Sobre o assunto, THOMPSON ANDRADE, ex-Conselheiro do CADE, esclarece que "dado que pode ser extremamente difícil obter provas diretas, a investigação de indícios indiretos é importante como tentativa de 
Essa abordagem foi adotada, por exemplo, no julgamento de processo administrativo relativo ao mercado de aços planos, que resultou na primeira condenação por cartel da história do CADE. Naquela oportunidade, o Conselheiro Ruy Santacruz reconheceu que "a maior parte da prova colhida nos processos do CADE pauta-se em indícios que, analisados à luz da teoria econômica, fazem concluir pela existência de uma conduta restritiva da concorrência" $"$.

Um dos indícios mais comuns da prática de cartel é o paralelismo de conduta entre os concorrentes, como a ocorrência de reajustes de preços pelos agentes do mercado em patamares similares e em datas próximas.

Entretanto, embora em algumas situações o paralelismo de conduta de fato seja o reflexo de um cartel, em muitos casos tal comportamento nada mais é do que simples decorrência do comportamento racional e legítimo das empresas. Em mercados competitivos, por exemplo, o preço não é definido individualmente pelas empresas, mas é dado pelo mercado segundo a lei da oferta e da procura, sendo, em regra, uniforme. Nessas situações, o paralelismo de preços pode ser apenas reflexo da competitividade do mercado $^{64}$. Por tais razões, a jurisprudência do CADE consolidou entendimento no sentido de que a simples existência de paralelismo de conduta não constitui prova suficiente da existência de cartel ${ }^{65}$.

enquadrar o comportamento de potenciais empresas cartelizadas dentro de uma moldura que tipifique suas práticas como anticoncorrenciais" ("Julgamento de Cartéis e o Uso de Provas Indiretas" in Revista de Direito da Concorrência, n 1, jan./mar., 2004, p. 18).

63 Processo Administrativo no 08000.015337/1997-48, Conselheiro Relator Ruy Santacruz, julgado em 27.10.1999.

${ }^{64}$ Como esclarece CÉSAR COSTA Alves DE MATTOS, “além de aumentos simultâneos de preços não poderem ser caracterizados isoladamente como cartéis, a verificação de preços muito próximos ou iguais também não pode ser indicadora, por si só, de conluio. Em setores com produtos bem homogêneos e grande transparência dos preços de mercado ao consumidor, é esperada uma grande uniformidade pelo próprio processo de concorrência" ("Introdução à Teoria Econômica dos Cartéis", in MARIO GOMES SCHAPIRO, VINÍCIUS Marques de CARvalho e LeOnOR Cordovil (coord.), Direito Econômico Concorrencial, São Paulo, Saraiva, 2013, p. 282).

65 A título de exemplo, podem ser mencionados os seguintes precedentes do CADE nos seguintes casos: Averiguação Preliminar no 08012.002996/2003-11, Conselheiro Relator Luiz Carlos Delorme Prado, julgado em 29.3.2006 ("Não há nos autos qualquer elemento que possa se somar aos indícios apontados pela ANP (baixa variação de preços) de forma a caracterizar ação colusiva. Os indícios trazidos aos autos são insuficientes para caracterizar a existência de cartel. Assim, tais fatos não estão aptos a ensejar qualquer punição por ofensa à Lei Antitruste"); Averiguação Preliminar no 08700.002194/1999-51, Conselheiro Relator Paulo Furquim de Azevedo, julgado em 17.1.2007 ("Como ponto de partida, é importante notar que a baixa variância de preços não é condição suficiente para caracterizar ação concertada, sendo também 
Desse modo, para que a existência de cartel seja considerada suficientemente provada, a jurisprudência do CADE entende que, além do paralelismo, são necessários elementos indiciários adicionais. Essa abordagem é conhecida como teoria do "paralelismo plus", adotada há várias décadas nos Estados Unidos no julgamento de casos de cartel.

De acordo com essa teoria, verificada a existência de comportamento paralelo entre os agentes, a autoridade conclui pela existência de cartel caso existam indícios adicionais - os chamados "plus factors" -, que permitam inferir a existência de um acordo ilícito entre os concorrentes. Dentre os "plus factors" levados em conta pela jurisprudência norte-americana, destaca-se a demonstração da ocorrência de reuniões e comunicações entre concorrentes em datas próximas aos reajustes simultâneos de preços ${ }^{66}$.

compatível, no caso de produtos homogêneos, com o comportamento em concorrência"); Averiguação Preliminar $n^{\circ}$. 08012.007813/2003-54, Conselheiro Relator Luís Fernando Rigato Vasconcellos, julgado em 27.6.2007 ("A baixa variabilidade de preços não é suficiente para, sozinha, caracterizar a existência de cartel. Vale ainda ressaltar que não há nos autos qualquer evidência que corrobore a existência de conduta cartelizada tais como depoimentos, indícios de reuniões, etc."). Examinando o entendimento do CADE sobre a matéria, THOMPSON ANDRADE esclarece que "estes julgados se basearam na impossibilidade de demonstrar que haveria conluio entre as empresas, pois que haveria pelo menos uma explicação econômica razoável para o observado, ou seja, haveria uma racionalidade econômica no comportamento das empresas" ("Julgamento de cartéis e o Uso de provas indiretas", cit., p. 18).

${ }^{66}$ Em 1954, a Suprema Corte norte-americana estabeleceu que o mero paralelismo de conduta não constitui prova suficiente de colusão entre empresas (Theatre Enterprises v. Paramount Film Distributing Corp., 346 U.S. 537, 1954). A partir dessa decisão, os tribunais passaram a exigir elementos probatórios adicionais (os chamados "plus factors") para condenar o agente econômico pela prática de cartel. Embora os julgados não tenham estabelecido uma hierarquia de fatores adicionais a serem levados em conta, é possível extrair alguns princípios a partir da análise da jurisprudência. Dentre os fatores adicionais mais importantes estão aqueles que mostram que a conduta seria vantajosa se os agentes agissem de forma colusiva, mas seria desvantajosa se agissem de forma independente (Interstate Circuit, Inc. v. United States, 306 U.S. 2008, 1939). Nesse grupo incluem-se, por exemplo, provas de padronização artificial de produtos (Dimidowich v. Bell \& Howell, 803 F.2d 1473, 1479-80, 9th Cir., 1986, dentre outros). Por outro lado, quando o agente econômico consegue provar que havia justificativa comercial legítima para determinada conduta, esta não pode ser utilizada para inferir colusão (Corner Pocket of Sioux Falls, Inc. v. Video Lottery Techs., 123 F.3d 1107, 1112, 8th Cir., 1997). Outros fatores adicionais levados em conta pelos tribunais norte-americanos são a existência de correspondências, reuniões ou outras comunicações entre concorrentes, principalmente se seguidas de paralelismo de conduta (Flat Glass Antitrust Litig., 385 F.3d 350, 369, 3d Cir., 1999). No entanto, desde o caso Matsuhita, os tribunais entendem que provas de reuniões ou comunicações que apenas demonstrem que havia oportunidade para o conluio não são suficientes para inferir a existência de cartel, desde que o agente econômico acusado demonstre justificativa comercial legítima para o contato com o concorrente (Matsuhita Elec. Indus. Co. v. Zenith Radio Corp., 475 U.S. 574, 587, 1986). 
O CADE aplicou a teoria do "paralelismo plus" para fundamentar a condenação de empresas em casos relativos aos segmentos de aços planos (1999) ${ }^{67}$, aviação (ponte aérea entre São Paulo e Rio de Janeiro) $(2004)^{68}$ e frigoríficos $(2008)^{69}$.

Nesses casos, embora não tenham sido encontradas provas diretas da existência de um acordo, o CADE inferiu a prática de cartel a partir da demonstração do paralelismo de conduta entre os agentes - no caso, sob a forma de variações similares de preços na mesma época - aliada à presença de elementos indiciários adicionais. Entre estes elementos adicionais estiveram a existência de reuniões prévias entre os agentes em datas próximas aos aumentos e análises de mercado sugerindo que não haveria explicação alternativa para o paralelismo que afastasse a hipótese de cartel.

Em síntese, a condenação em âmbito administrativo com base em indícios de cartel não é incompatível com o ordenamento jurídico brasileiro, eis que, mesmo na esfera penal, em que uma decisão condenatória pode implicar restrição da liberdade do acusado, admite-se a condenação a partir de prova indiciária. Para tanto, o CADE deve seguir os parâmetros da doutrina e jurisprudência em matéria penal, segundo os quais a condenação com base em indícios pressupõe a existência de uma pluralidade de indícios graves e concatenados, que apontem para a mesma direção e excluam qualquer hipótese favorável ao acusado ${ }^{70}$.

Depois de examinada a utilização de indícios como prova do cartel, devem ser analisados os casos em que o CADE empregou evidências diretas do acordo como

\footnotetext{
${ }^{67}$ Processo Administrativo $\mathrm{n}^{\mathrm{o}}$ 08000.015337/1997-48, Conselheiro Relator Ruy Santacruz, julgado em 27.10.1999.

${ }^{68}$ Processo Administrativo no 08012.000677/1999-70, Conselheiro Relator Thompson Andrade, julgado em 15.9.2004.

${ }^{69}$ Processo Administrativo no 08012.002493/2005-16, Conselheiro Relator Luís Fernando Schuartz, julgado em 30.1.2008.

70 São elucidativas, a respeito, as ementas dos seguintes julgados proferidos pelo Tribunal de Alçada Criminal de São Paulo: “A prova indiciária somente é bastante à incriminação do réu quando formadora de uma cadeia concordante de indícios sérios e graves, unidos por um liame de causa e efeito, excludentes de qualquer hipótese favorável ao acusado" (JTACRESP 38/167); “A prova indiciária somente autoriza a condenação quando concatenada e concorde, de molde a excluir toda e qualquer hipótese favorável ao acusado" (JTACRESP 61/301); "Os indícios têm força convincente quando muitos, concordes e concludentes. Indícios que permitam explicação diferente apenas levantam suspeitas. Não são aptos a conduzir a certeza" (JTACRESP 72/339); "Havendo argumentos que indicam a condenação e outros que aconselham a absolvição, estabelecendo, dessa forma, perplexidade no espírito do julgador, a solução mais justa e adequada é mesmo a absolutória" (JTACRESP 72/339).
} 
fundamento para a condenação. Com efeito, como resultado da priorização de esforços das autoridades na investigação de cartéis, passaram a ser cada vez mais comuns os casos em que o CADE não precisa recorrer a indícios, fundamentando a condenação em provas diretas do acordo entre concorrentes.

Dentre as provas levadas em conta pelo CADE incluem-se atas de reuniões, transcrições de conversas telefônicas, depoimentos de testemunhas e de beneficiários de acordo de leniência, arquivos físicos e eletrônicos das empresas, dentre outras. Os principais casos em que a decisão condenatória do CADE se baseou em provas diretas do acordo são os seguintes:

i) combustíveis de Florianópolis (2002): o primeiro caso em que o CADE condenou os representados - revendedores de combustíveis no Município de Florianópolis baseado em provas emprestadas oriundas de interceptação telefônica realizada na esfera penal $^{71}$;

ii) pedra britada (2005): processo administrativo que investigou a formação de cartel no mercado relevante de pedra britada na região metropolitana de São Paulo - SP, tendo sido o primeiro caso em que o CADE condenou os representados com base em provas obtidas mediante busca e apreensão nas sedes das empresas representadas autorizada com fundamento no artigo 35-A da Lei 8.884/94 ${ }^{72}$;

iii) vigilantes (2007): processo administrativo que investigou a formação de cartel entre empresas de vigilância privada no Estado do Rio Grande do Sul, tendo sido a primeira condenação do CADE amparada em provas fornecidas por beneficiários de acordo de leniência ${ }^{73}$;

iv) extração de areia (2008): o CADE concluiu pela formação de cartel entre empresas atuantes no mercado de extração de areia em Porto Alegre - RS, com base em

\footnotetext{
${ }^{71}$ Processo Administrativo $\mathrm{n}^{\circ}$ 08012.002299/2000-18, Conselheiro Relator Afonso Arinos de Mello Franco Neto, julgado em 27.03.2002.

72 Processo Administrativo n ${ }^{\circ}$ 08012.002127/2002-14, Conselheiro Relator Luiz Carlos Delorme Prado, julgado em 13.07.2005.

73 Processo Administrativo nº 08012.001826/2003-10, Conselheiro Relator Abraham Benzaquem Sicsú, julgado em 24.10.2007.
} 
provas emprestadas obtidas mediante busca e apreensão realizada na esfera $\operatorname{criminal}^{74}$

v) gases industriais (2010): o CADE investigou a prática de cartel no mercado nacional de gases industriais, tendo condenado os representados com base em provas emprestadas oriundas de busca e apreensão realizada na esfera penal ${ }^{75}$;

vi) peróxido de hidrogênio (2012): processo administrativo que investigou a prática de cartel no mercado brasileiro de peróxido de hidrogênio, tendo o CADE condenado os representados com base em informações obtidas em acordo de leniência e posterior busca e apreensão realizada nas sedes das empresas investigadas ${ }^{76}$;

vii) frete aéreo (2013): processo administrativo que investigou a cobrança coordenada de adicional de combustível por empresas prestadoras de serviços de frete aéreo para o exterior, tendo o CADE condenado os representados com base em informações obtidas em acordo de leniência e busca e apreensão ${ }^{77}$; e

viii) cimento (2014): processo administrativo que condenou as empresas do mercado nacional de cimentos pela prática de cartel, com base, dentre outras provas, em documentos obtidos em busca e apreensão autorizada com fundamento no art. 35-A da Lei $8.884 / 94^{78}$.

Deve-se mencionar, ainda, a tendência de alguns julgados do CADE de concluírem pela existência de cartel com base apenas na evidência de acordo, dispensando a demonstração da potencialidade de produção de efeitos anticompetitivos, aproximandose da abordagem de ilicitude "per se" adotada em outros países, como, por exemplo, os

\footnotetext{
${ }^{74}$ Processo Administrativo $\mathrm{n}^{\mathrm{o}}$ 08012.000283/2006-66, Conselheiro Relator Paulo Furquim de Azevedo, julgado em 17.12.2008.

${ }^{75}$ Processo Administrativo no 08012.009888/2003-70, Conselheiro Relator Fernando de Magalhães Furlan, julgado em 01.09.2010.

${ }^{76}$ Processo Administrativo $\mathrm{n}^{\circ}$ 08012.004702/2004-77, Conselheiro Relator Carlos Emmanuel Joppert Ragazzo, julgado em 09.05.2012.

${ }^{77}$ Processo Administrativo n ${ }^{\circ}$ 08012.011027/2006-02, Conselheiro Relator Ricardo Machado Ruiz, julgado em 22.08.2013.

${ }^{78}$ Processo Administrativo no 08012.011142/2006-79, Conselheiro Relator Alessandro Octaviani Serafin, julgado em 28.05.2014.
} 
Estados Unidos. Veja-se, por exemplo, a interpretação defendida pelo Conselheiro Luiz Carlos Delorme Prado no julgamento do processo administrativo que investigou a prática de cartel no mercado de pedra britada ${ }^{79}$ :

\begin{abstract}
"Observe-se que o Cartel Clássico é uma das exceções no direito antitruste brasileiro em que pode ser caracterizado como ilícito per se, ou seja, é suficiente provar sua existência para determinar sua ilicitude. (...) Portanto, estabelecida as condições de existência de um Cartel Integral, alcança-se aquele quantum probatório, em que uma decisão pode ser exarada. Desta forma, não há que se provar efeitos. Estudos econométricos nesse caso são desnecessários, controversos e irrelevantes para a caracterização da conduta ou da gravidade do ilícito".
\end{abstract}

Não obstante tal posicionamento seja justificável em outros ordenamentos, o fato é que, no direito brasileiro, a estrutura dos ilícitos previstos na Lei 12.529/2011 pressupõe a existência não apenas de um ato anticompetitivo, mas também da aptidão objetiva do ato para gerar os efeitos pretendidos. Desse modo, o direito concorrencial brasileiro não admite o tratamento de condutas como ilícitos "per se", sendo imprescindível a demonstração da produção, ao menos potencial, de algum dos efeitos descritos na lei: limitação e falseamento da concorrência, dominação de mercados, aumento arbitrário de lucros e abuso de posição dominante.

Em síntese, não há como negar que a investigação de cartéis na esfera administrativa se intensificou significativamente nos últimos anos, tendo havido incremento expressivo da quantidade de processos administrativos e decisões condenatórias pelo CADE. Contribuíram para esse desenvolvimento algumas importantes alterações legislativas que permitiram às autoridades empregar meios bastante eficazes para obtenção de provas do acordo entre concorrentes, como a realização de buscas e apreensões $^{80}$ e a celebração de acordos de leniência ${ }^{81}$.

\footnotetext{
${ }^{79}$ Processo Administrativo n ${ }^{\circ}$ 08012.002127/2002-14, julgado em 13.07.2005, pp. 8-10 do voto.

${ }^{80}$ A Lei $\mathrm{n}^{\mathrm{o}}$ 10.149, de 21 de dezembro de 2000, alterou a Lei 8.884/1994, introduzindo o art. 35-A, que possibilitava que a SDE solicitasse, por meio da Advocacia-Geral da União, busca e apreensão para instrução de processos administrativos instaurados para investigar a prática de infrações à ordem econômica. A Lei 12.529/2011, que revogou a Lei 8.884/1994, contém regra semelhante: “Art. 13. Compete à Superintendência-Geral: (...) d) requerer ao Poder Judiciário, por meio da Procuradoria Federal junto ao CADE, mandado de busca e apreensão de objetos, papéis de qualquer natureza, assim como de livros comerciais, computadores e arquivos magnéticos de empresa ou pessoa física, no interesse de inquérito administrativo ou de processo administrativo para imposição de sanções administrativas por infrações à ordem econômica, aplicando-se, no que couber, o disposto no art. 839 e seguintes da Lei no 5.869, de 11 de janeiro de 1973 - Código de Processo Civil, sendo inexigível a propositura de ação principal”.
} 
Embora após a entrada em vigor da Lei 12.529/2011 o CADE tenha dedicado esforços consideráveis para viabilizar a instituição do controle prévio de atos de concentração - o que, por um período, pode ter afetado os esforços para investigação de condutas anticompetitivas - pode-se prever que a investigação de infrações à ordem econômica, em especial os cartéis, continuará a ser item prioritário da pauta do $\mathrm{CADE}^{82}$. A existência de decisões condenatórias recentes pelo CADE em matéria de cartel confirma esse prognóstico.

\subsection{Esfera penal: o crime de cartel}

A análise aprofundada do crime de cartel escapa aos limites do presente trabalho. De qualquer modo, serão examinados brevemente a seguir os principais elementos da disciplina jurídica dos cartéis na esfera penal.

$\mathrm{O}$ art. $4^{\circ}$ da Lei $\mathrm{n}^{\circ} 8.137 / 1990$ tipifica a prática de cartel como crime, punível com pena de reclusão de dois a cinco anos e multa. Veja-se o teor do dispositivo:

"Art. $4^{\circ}$ Constitui crime contra a ordem econômica:

I - abusar do poder econômico, dominando o mercado ou eliminando, total ou parcialmente, a concorrência mediante qualquer forma de ajuste ou acordo de empresas;

II - formar acordo, convênio, ajuste ou aliança entre ofertantes, visando:

a) à fixação artificial de preços ou quantidades vendidas ou produzidas;

b) ao controle regionalizado do mercado por empresa ou grupo de empresas;

c) ao controle, em detrimento da concorrência, de rede de distribuição ou de fornecedores.

Pena - reclusão, de 2 (dois) a 5 (cinco) anos e multa".

${ }^{81}$ Os acordos de leniência passaram a ser admitidos pela Lei 8.884/1994 após as alterações introduzidas pela Lei 10.149/2000. Atualmente, os acordos de leniência são disciplinados pelos artigos 86 e seguintes da Lei 12.529/2011. Esses acordos são celebrados entre a administração e pessoas físicas ou jurídicas e permitem a redução da penalidade ou a extinção da punibilidade (em âmbito administrativo e criminal) para aqueles que confessarem a prática de infração à ordem econômica e auxiliarem nas investigações. Esse auxílio deve ser efetivo e resultar na identificação dos coautores da infração e na obtenção de documentos comprobatórios da prática.

${ }^{82}$ Nesse sentido, o então Superintendente-Geral do CADE, Carlos Emmanuel Joppert Ragazzo e o atual Presidente do CADE, Vinícius Marques de Carvalho, declararam que o CADE deverá manter o foco nos próximos anos na investigação de prática anticompetitivas, em especial cartéis ("Depois da onda de fusões, CADE quer concentrar atuação nas investigações”, Valor Econômico, 19.06.2012). 
$\mathrm{Na}$ doutrina, prevalece o entendimento de que o crime previsto no inciso I constitui crime de resultado, sendo necessário, para sua configuração, que haja efetiva dominação do mercado ou eliminação da concorrência ${ }^{83}$.

Critica-se a excessiva generalidade do tipo penal previsto no inciso I do dispositivo, o qual em tese possibilita a persecução penal do abuso de poder econômico genericamente considerado, e não apenas da formação de cartel. Nesse sentido, ANA Paula Martinez defende, de lege ferenda, a revogação do inciso I do art. $4^{\circ}$ da Lei $8.137 / 1990$, sustentando que a persecução penal em matéria concorrencial deveria ser reservada à prática de $\operatorname{cartel}^{84-85}$ :

\begin{abstract}
"Uma política pública que confira tratamento penal a um amplo rol de infrações à ordem econômica pode ser fonte de alta ineficiência social, ao inserir um elemento de incerteza na condução das atividades econômicas e restringir a criatividade e a liberdade dos executivos de buscarem novas políticas e arranjos comerciais - o que é crítico, considerando a importância da inovação para o desenvolvimento. (...) Como visto (...), a ampla redação do artigo $4^{\circ}$, I, da Lei $8.137 / 1990$ permite que qualquer abuso de poder econômico decorrente de ajustes ou acordo entre empresas que leve à dominação do mercado ou eliminação da concorrência seja perseguido criminalmente. Isso significa que, nos termos do ordenamento jurídico atual, indivíduos responsáveis por acordos de exclusividade, fixação de preços de revenda e mesmo fusões e aquisições anticompetitivos estão sujeitos à imputação penal - regra que deveria ser extirpada de nosso ordenamento (...)".
\end{abstract}

O crime previsto no inciso II, por sua vez, está relacionado à prática de cartel, prevendo-se que constitui crime a formação de "acordo, convênio, ajuste ou aliança entre ofertantes" 86 visando à fixação artificial de preços ou quantidades (alínea $a$ ), ao

${ }^{83}$ Eduardo Reale Ferrari e JoÃo Augusto Prado da Silleira Gameiro, O Cartel de Empresas e seus Aspectos Criminais, sem data, disponível em: 〈http://www.realeadvogados.com.br/opinioes/edu_joao.pdf >. Acesso em 8.nov.2014, p. 13.

${ }^{84}$ Repressão a Cartéis..., p. 291.

${ }^{85}$ Nos Estados Unidos, a Comissão para Modernização do Direito Antitruste ("Antitrust Modernization Commission"), criada por lei com o objetivo de avaliar e propor aperfeiçoamentos ao direito antitruste norteamericano, sustenta, de modo semelhante, que "while no change to existing law is recommended, the Antitrust Division of the Department of Justice should continue to limit its criminal enforcement activity to 'naked' price-fixing, bid-rigging, and market or customer allocation agreements among competitors, which inevitably harm consumers" (Antitrust Modernization Commission: Report and Recommendations, 2007, disponível em: <http://govinfo.library.unt.edu/amc/report_recommendation/amc_final_report.pdf>. Acesso em: 17.mar.2013, p. 295).

${ }^{86}$ Sobre os conceitos de acordo, convênio, ajuste ou aliança entre ofertantes, veja-se o ensinamento de LUIZ REGIS PRADO: "Por ajuste, na seara penal, entende-se o acordo, livre e consciente, feito entre vários indivíduos com o objetivo de praticar um fato punível. O acordo é 'a convenção ou ajuste entre contratantes, 
controle regionalizado do mercado (alínea $b$ ) ou ao controle da rede de distribuição ou fornecedores (alínea $c$ ).

Trata-se de crime de perigo concreto, de modo que, para sua configuração, não se exige a efetiva ocorrência do dano, sendo suficiente a potencialidade de geração de efeitos anticompetitivos ${ }^{87}$.

É possível notar uma discrepância entre a definição de cartel apresentada no artigo 36, § 36 Lei 12.529/2011, discutido acima, e a definição do inciso II do art. $4^{\circ}$ da Lei 8.137/1990. Na doutrina, defende-se de lege ferenda a compatibilização do dispositivo da lei penal com a norma prevista na lei concorrencial, de modo a evitar decisões conflitantes $^{88}$.

Especificamente com relação à prática de cartel em licitações, a Lei $\mathrm{n}^{\circ}$ 8.666, de 21 de junho de 1993 dispõe que a conduta constitui crime punido com reclusão de dois a quatro anos e multa, nos seguintes termos ${ }^{89}$ :

“Art. 90. Frustrar ou fraudar, mediante ajuste, combinação ou qualquer outro expediente, o caráter competitivo do procedimento licitatório, com o intuito de obter, para si ou para outrem, vantagem decorrente da adjudicação do objeto da licitação: Pena - detenção, de 2 (dois) a 4 (quatro) anos, e multa.".

conjugando suas vontades para a efetivação do ato negocial, gerando uma obrigação de dar, de fazer ou não fazer' (...). O convênio é o 'instrumento de declaração de vontades que se encontram e se integram, dirigindo-se, todas elas, a um objetivo comum, sem que, portanto, umas às outras se oponham; não há oposição e sim conjugação de interesses', e a aliança é 'o acordo, a coligação feita entre instituições ou pessoas para um fim comum'. Ofertante é quem oferece bens ou serviços no mercado, por determinado preço e por determinado período de tempo" (Direito Penal Econômico, $3^{\mathrm{a}}$ ed., São Paulo, Revista dos Tribunais, 2009, pp. 45-49).

${ }^{87}$ Ana PaUla Martinez, Repressão a Cartéis..., cit., pp. 186-189.

${ }^{88}$ Sobre o assunto, EDUARDo REALE FERRARI e JoÃo AUgusto PrAdO DA SILVEIRA GAMEIRO sustentam que “a legislação penal peca pela falta de técnica jurídica e legislativa; primeiro porque a lei se mostra, em alguns pontos, totalmente alheia aos conceitos da Lei 8.884/94, destacando que, mesmo após a sua superveniência, não se operaram as adequações necessárias à tipificação dos crimes" ( $O$ Cartel de Empresas e seus Aspectos Criminais, cit., 13). No mesmo sentido, ANA PAUlA MARTINEZ sustenta que "definições distintas para a prática de cartel clássico hoje contidas na Lei 8.137/1990 e na Lei 12.529/2011 podem gerar dificuldades práticas de cooperação entre autoridades criminais e administrativas, além de aumentar a probabilidade de decisões conflitantes, razão pela qual se sugere a uniformização dos dispositivos" (Repressão a Cartéis..., cit., p. 291).

89 De acordo com ANA PAUla MARTINEZ, "se houver formação de cartel no âmbito de um processo licitatório público, haverá a aplicação da Lei 8.666/1993 com base nos princípios da especialidade e da consunção, desde que presentes os elementos do tipo. Fraudes a licitações privadas continuam sendo regidas pela Lei 8.137/1990" (Repressão a Cartéis..., cit., p. 196). 
As principais diferenças entre a disciplina dos cartéis nas esferas administrativa e penal - além das penalidades aplicáveis -, residem nos seguintes fatores: (i) a responsabilidade pela prática de cartel no âmbito penal é restrita às pessoas físicas, enquanto na esfera administrativa admite-se a punição de pessoas físicas e jurídicas; e (ii) a responsabilização na esfera penal exige a demonstração de dolo do agente, enquanto na esfera administrativa, como visto, admite-se a responsabilidade por simples culpa (no caso das pessoas físicas) ou até mesmo sem demonstração de culpa (no caso das pessoas jurídicas $)^{90}$.

Nos últimos anos, dois fatores contribuíram para o incremento da persecução penal de cartéis no Brasil. O primeiro fator foi a criação, no âmbito dos Ministérios Públicos Estaduais e da Polícia Federal, de áreas especializadas destinadas a investigar crimes de cartel, como, por exemplo, o Grupo de Atuação Especial de Repressão à Formação de Cartéis e Lavagem de Dinheiro ("GEDEC") do Ministério Público do Estado de São Paulo, criado em outubro de 2008.

O segundo fator foi o aprofundamento da cooperação entre as autoridades administrativas de defesa da concorrência e as autoridades de investigação e persecução penal, mediante a criação de convênios de cooperação técnica e operacional com o objetivo de coordenar as atividades dos diferentes órgãos responsáveis pela investigação de práticas anticompetitivas $^{91}$.

\footnotetext{
${ }^{90}$ Nesse sentido, CALIXTO SALOMÃo FILHO ensina que "os crimes ora analisados são do tipo doloso, isto é, pressupõe-se o conhecimento do tipo e a autodeterminação consciente na sua realização. Mais do que isso, estamos diante de um exemplo claro de dolo específico, isto é, 'a conduta típica deve ser realizada para alcançar um fim que transcende o momento consumativo do fato punível'. (...) Por outro lado, o art. 11 da Lei n. 8.137/90, praticamente reproduzindo os termos do art. 29 do Código Penal, estabelece a responsabilidade exclusiva das pessoas físicas pelos crimes ora analisados" ("Cartel: Aspectos Concorrenciais e Penais", in Regulação e Concorrência..., cit., pp. 183). No mesmo sentido, LUIZ REGIS PRADO sustenta que "o tipo subjetivo é representado pelo dolo, elemento subjetivo geral dos tipos constantes no artigo $4^{\circ}$ e incisos, ou seja, para sua configuração exigem-se a consciência e a vontade de realizar o tipo objetivo do delito. Ademais, há a presença do elemento subjetivo do injusto consistente num especial fim de agir, que, nesses casos, é o de dominar o mercado ou eliminar, total ou parcialmente, a concorrência (delitos de tendência)" (Direito Penal Econômico, cit., p. 54).

${ }^{91}$ Em 26.12.2007 a SDE, órgão então responsável pela instrução dos processos administrativos para investigação de infrações à ordem econômica, firmou convênio de cooperação técnica-operacional com a Polícia Federal. Em 24.05.2008, foi firmado convênio entre a SDE e o Ministério Público Federal. Também foram celebrados convênios com instituições estaduais, como o Ministério Público da Paraíba, de 11.04.2008, e o Ministério Público de São Paulo, do qual resultou a criação do GEDEC, mencionado acima. Em 08.10.2009, diversas autoridades públicas envolvidas na investigação de cartéis firmaram a "Declaração de Brasília", pela qual foi estabelecida a Estratégia Nacional de Combate a Cartéis ("ENACC"), que visa "fomentar a definição de um plano coordenado e sistemático de atividades entre os diversos órgãos estatais responsáveis pela investigação e repressão às infrações à ordem econômica" (Declaração de Brasília -
} 
Embora tais esforços não tenham se refletido até o momento em número expressivo de decisões condenatórias definitivas ${ }^{92}$ - em especial quando comparado com a persecução penal de cartéis em outros países, como os Estados Unidos ${ }^{93}$ - a maior importância conferida à persecução penal de cartéis no Brasil pode ser notada pelo número crescente de processos e investigações em curso ${ }^{94}$.

Estratégia Nacional de Combate a Cartéis - ENACC, "Combate a Cartéis: uma prioridade na política criminal e administrativa"). Sobre o tema, ANA PAULA MARTINEZ avalia que "a criação do novo CADE, com estrutura única mais racional e alinhada com as melhores práticas internacionais, trouxe externalidade negativa para a cooperação entre autoridades administrativas e criminais. No regime anterior, a Secretaria de Direito Econômico, responsável pela investigação de condutas anticompetitivas na vigência da Lei 8.884/1994, beneficiou-se largamente do fato de ter como órgãos-irmãos o Departamento de Polícia Federal e a Secretaria Nacional de Segurança Pública, no âmbito do Ministério da Justiça. Isso não quer dizer, claro, que uma atuação coordenada não seja possível, mas apenas que isso requererá maior esforço das partes envolvidas no bojo do novo sistema" (Repressão a Cartéis..., cit., p. 245).

${ }^{92}$ Ao analisar recentemente o sistema de persecução penal de cartéis no Brasil, a OCDE relatou: "Os dados sobre processos penais referentes a cartéis são, infelizmente, incompletos. Ainda assim, o SBDC relata que trinta e quatro indivíduos foram condenados criminalmente desde que a iniciativa começou. A maioria desses indivíduos estava envolvida em conluios locais ou regionais, particularmente em cartéis na revenda de combustíveis. Destes, dez receberam sentenças de prisão, mas nenhuma dessas sentenças foi cumprida até a presente data, pois todos os casos estão em fase recursal" (Direito e Política da Concorrência no Brasil..., cit., p. 19).

93 "Criminal antitrust prosecution is a vital component of overall antitrust enforcement in the United States. (...) The Antitrust Division of the Department of Justice (DOJ) has made the detection, criminal prosecution, and deterrence of hard-core antitrust offenses its highest priority. This priority, in combination with improved enforcement tools, cooperation from international antitrust enforcers, and a robust amnesty program, have led to the detection and prosecution of an ever-increasing number of cartels, often global in scope. These cartels can affect millions, if not billions, of dollars in commerce. Congress has recognized the seriousness of these economic crimes, and has recently substantially increased maximum fines and jail sentences and authorized the DOJ to use wiretaps in the investigation of suspected criminal cartel conduct" (Antitrust Modernization Commission..., cit., p. 293).

${ }^{94}$ Nos termos do relatório da OCDE "o SBDC informa que, até o final de 2009, cerca de 100 indivíduos estavam sendo formalmente acusados por crime de formação de cartel ou estavam sob investigação por tal atividade criminosa." (Direito e Política da Concorrência no Brasil..., cit., p. 19). 


\section{PARTE II - CARTEL E RESPONSABILIDADE CIVIL}

\section{O PAPEL DA RESPONSABILIDADE CIVIL NO CONTEXTO DA DEFESA DA CONCORRÊNCIA}

Este capítulo tem o objetivo de apresentar um panorama acerca do debate travado na doutrina concorrencial sobre o papel das ações de indenização no contexto da política de defesa da concorrência. As ideias discutidas neste capítulo servirão de importante referencial teórico para a análise da disciplina da responsabilidade civil por danos decorrentes de cartel no direito estrangeiro e no direito brasileiro, o que será objeto de estudo nos capítulos subsequentes.

Há anos se discute na doutrina concorrencial acerca do papel desempenhado pelas ações de indenização no contexto mais amplo das políticas de defesa da concorrência. De modo geral, reconhece-se que as ações pleiteando indenizações por danos decorrentes de cartéis e outras práticas anticompetitivas têm a vocação de servir a dois objetivos principais, complementares entre si: reparação dos danos sofridos pelos prejudicados e desestímulo à prática de infrações concorrenciais.

Nesse sentido, HERBERT HOVEMKAMP escreve ${ }^{95-96}$ :

"the rationale for private antitrust damages actions could be either compensation or deterrence. The goal of an enforcement system based on compensation is to restore injured parties to their position had the violation not occurred. The goal of an enforcement system based on deterrence is to identify some optimal level of violations that should be eliminated, and make that level of violations unprofitable by imposing costs on prospective violators."

De modo semelhante, documento publicado pela Comissão Europeia sobre a reparação de danos decorrentes de práticas anticompetitivas destaca ${ }^{97}$ :

\footnotetext{
95 Federal Antitrust Policy - The Law of Competition and its Practice, $2^{\text {nd }}$ ed., St. Paul - Minnesota, West Group, 1999, p. 645.

96 No mesmo sentido, LAWrenCE A. SUllivan e WARREN S. GRIMES destacam que "the case for private enforcement thus rests on twin goals: deterrence and compensation" (The Law of Antitrust: An Integrated Handbook, St. Paul - Minnesota, West Group, 2000, p. 912).
} 
"damages actions for infringement of antitrust law serve several purposes, namely to compensate those who have suffered a loss as a consequence of anti-competitive behaviour and to ensure the full effectiveness of the antitrust rules of the Treaty by discouraging anti-competitive behaviour, thus contributing significantly to the maintenance of effective competition in the Community (deterrence)."

Pode-se traçar um interessante paralelo entre o debate acima e a discussão mais ampla da doutrina civilista sobre o papel da responsabilidade civil. Com efeito, embora sejam apontadas diversas funções para as normas de responsabilidade civil, as funções principais atribuídas pela doutrina civilista são também as seguintes: (i) função reparatória ou compensatória; e (ii) função preventiva ${ }^{98}$, cuja importância costuma ser destacada com relação a delitos praticados com o objetivo de obter ganho financeiro, como é o caso das infrações concorrenciais ${ }^{99}$. Essas duas funções (reparatória e preventiva) serão examinadas a seguir, no contexto específico da responsabilidade civil em matéria concorrencial.

\subsection{O objetivo de reparação dos danos sofridos pelos prejudicados}

O primeiro e mais intuitivo objetivo da responsabilidade civil antitruste apontado pela doutrina concorrencial é a reparação dos danos sofridos pelos prejudicados

${ }^{97}$ Green Paper on Damages Actions for Breach of the EC Antitrust Rules, 2005, disponível em: <http://eurlex.europa.eu/LexUriServ/site/en/com/2005/com2005_0672en01.pdf>. Acesso em: 2.abr.2013, p. 4.

${ }^{98}$ Nesse sentido, TERESA ANCONA LOPEZ escreve que "na doutrina estrangeira, divergem os autores sobre o elenco das funções da responsabilidade civil, mas em todas elas há sempre duas funções que são primordiais: a) a função reparatória ou compensatória; b) a função preventiva" (Princípio da Precaução..., cit., pp. 7273). Sobre a função preventiva da responsabilidade civil, vide: Diogo NAVES MENDONÇA, Análise Econômica da Responsabilidade Civil - O Dano e sua Quantificação, São Paulo, Atlas, 2012.

$99 \mathrm{Na}$ doutrina francesa, ANDRÉ TUNC destaca a existência de quatro funções da responsabilidade civil: prevenção de comportamentos antissociais, indenização da vítima, diluição dos riscos e garantia dos direitos dos cidadãos. Especificamente com relação à função preventiva, o autor destaca que tal função é especialmente importante com relação aos delitos praticados com o intuito de obter ganho financeiro, fazendo expressa menção às infrações à legislação antitruste. Nas palavras do autor: “(...) dans les cas de dommages à des intérêts d'affaires, tels que ceux qui resultent de concurrence déloyale, de mèconnaissance des droits de propriété industrielle, de violation de lois antitruste, la responsabilité civile est souvent beaucoup plus effective que la responsabilité pénale. Cette dernière ne peut être utilisée qu'en cas de violation claire et volontaire de la loi. Or, souvent, la dilution de la décision das une grande entreprise empêche qu'une sentence d'emprisonnement soit prononcée. Souvent aussi, la simple difficulté d'apprécier si l'activité est légale ou illégale (une question qui peut avoir été discutée longuement par des juristes spécialisés avant que la firme ne décide de s'engager dans l'activité) laisse le juge hésitant à imposer même des amendes importantes sur des individus. En revanche, la menace des dommages-intérêts qui peuvent se chiffrer en centaines de millions ou en milliards peut être un facteur très effectif au moment où la décision va être prise de s'engages dans une certaine activité ou d'y renoncer" (La Responsabilité Civile, Paris, Economica, 1981, pp. 135-136). 
por práticas anticompetitivas. Como analisado no capítulo 1, uma das principais consequências do cartel é a transferência de renda dos adquirentes dos produtos ou serviços para os membros do cartel em decorrência do sobrepreço cobrado, além de outros efeitos adversos ao mercado.

Embora as multas e penas de prisão aplicadas aos agentes econômicos responsáveis pelo cartel tenham papel importante na prevenção de práticas anticompetitivas, tais sanções não se prestam a reparar os danos que resultam da conduta ilícita. Desse modo, a tarefa de reparar ou compensar os prejuízos sofridos pelos prejudicados fica a cargo das ações indenizatórias, sendo esse, naturalmente, um dos objetivos da responsabilidade civil em matéria antitruste ${ }^{100}$.

\subsection{O objetivo de prevenir a prática de infrações concorrenciais}

Além da reparação dos prejuízos, a doutrina concorrencial também destaca que a responsabilidade civil pode funcionar como importante fator de prevenção de práticas anticompetitivas ("deterrence”), complementando os esforços das autoridades de defesa da concorrência.

O modelo teórico comumente empregado no estudo das regras de prevenção de infrações à ordem econômica - e da possível contribuição das ações indenizatórias nessa tarefa - é a análise econômica do direito, que constitui ferramenta útil para a avaliação das normas destinadas à prevenção e dissuasão de práticas ilícitas ${ }^{101}$.

\footnotetext{
${ }^{100}$ Em documento da Comissão Europeia sobre a reparação de danos causados por infrações concorrenciais, destaca-se que "compensation of the harm is fundamental so that companies who comply with the law do not suffer from a competitive disadvantage, and victims who are harmed do not bear the costs of the infringements: these costs must be borne by the infringers. Victims have a right to compensation, as confirmed by the ECJ, and it is fundamental that they can enforce it effectively" (Commission Staff Working Paper accompanying the White Paper on Damages Actions for Breach of the EC Antitrust Rules, 2008, disponível em: <http://eur-lex.europa.eu/LexUriServ/LexUriServ.do?uri=SEC:2008:0404:FIN:EN:PDF>. Acesso em: 5.abr.2013, p. 10).

101 A análise econômica do direito, também conhecida como direito e economia, é uma corrente de pensamento que busca aplicar os principais conceitos da ciência econômica com o objetivo de explicar os efeitos de normas jurídicas sobre o comportamento dos agentes e avaliar a efetividade das normas. Como esclarece RACHEL SZTAJN “direito e economia ou análise econômica do direito, segundo alguns, uma escola ou corrente de pensamento que busca, para compreender e explicar efeitos de normas jurídicas, apoio em modelos e premissas desenvolvidos por economistas, é, para outros, apenas uma técnica de avaliação da eficácia das normas" ("Direito e Economia", in Revista de Direito Mercantil, Industrial, Econômico e Financeiro, vol. 144, out./dez., 2006, p. 221). Sobre os objetivos da análise econômica do direito, RICHARD A. POSNER escreve: "The economic analysis of law (...) has both positive (that is descriptive) and normative
} 
O estudo sistematizado da matéria foi iniciado na década de 60 do século passado por GARY S. BECKER, que foi o primeiro autor a aplicar um modelo de comportamento racional para explicar os incentivos levados em conta pelo agente que comete uma infração. $\mathrm{O}$ modelo descreve o infrator como um agente racional, que decide praticar determinado ato ilícito por concluir que os ganhos a serem auferidos com a prática ilícita são superiores ao prejuízo esperado em decorrência da sanção eventualmente aplicada caso a infração seja descoberta ${ }^{102}$.

O modelo pode ser sintetizado da seguinte forma: ao decidir sobre a conveniência de cometer determinado ato ilícito, o potencial infrator leva em conta os ganhos decorrentes da prática $(\mathrm{G})$ e o prejuízo esperado em razão de eventual sanção, o qual corresponde ao prejuízo efetivamente incorrido caso a sanção seja aplicada (P) multiplicado pela probabilidade de que a infração seja descoberta (p). Desse modo, na hipótese de os ganhos serem superiores ao prejuízo esperado ( $\mathrm{G}>$ P.p), o agente irá cometer a infração. Caso os ganhos sejam inferiores ao prejuízo esperado $(G<P . p)$, ele não cometerá a infração.

Diante disso, a sanção (S) que pretenda coibir adequadamente prática da infração deve corresponder ao benefício que o infrator acredite obter com a prática, multiplicado pelo inverso da probabilidade de que a sanção seja de fato aplicada (ou seja, $S$

aspects. It tries to explain and predict the behavior of participants in and persons regulated by the law. It also tries to improve law by pointing out respects in which existing or proposed laws have unintended or undesirable consequences (...)" ("Values and Consequences - An Introduction to Law and Economics", in ERIC POSNER (org.), Chicago Lectures in Law and Economics, New York, Foundation Press, 2000, p. 190). Com relação ao tema, PAULA FORGIONI observa que "o operador do Direito, ao se deparar com a AED e com seus postulados, não pode ser movido nem pela paranoia, nem pela mistificação: a relação entre o método jurídico e o método juseconômico deve ser de complementaridade e não de substituição ou oposição. Na ausência da correta compreensão da AED, de duas, uma: ou será desprezado instrumental apto a dar concreção aos princípios de nosso ordenamento jurídico, ou - o que é pior - a AED será tomada como remédio apto a solucionar todos os males, reduzindo o papel do direito à simples reafirmação e legitimação dos determinismos econômicos" ("Análise Econômica do Direito (AED): Paranoia ou Mistificação?", in Revista de Direito Mercantil, Industrial, Econômico e Financeiro, vol. 139, jul./set., 2005, p. 256).

102 Nas palavras do autor: "Rationality implied that some individuals become criminals because of the financials and other rewards from crime compared to legal work, taking account of the likelihood of apprehension and conviction and the severity of the punishment. (...) Total public expending on fighting crime can be reduced, while keeping the mathematically expected punishment unchanged, by off-setting a cut in expenditures on catching criminals with a sufficient increase in the punishment to those convicted." ("Nobel Lecture: The Economic Way of Looking at Behavior", in The Journal of Political Economy, vol. 101, n. 3, Jun., 1993, pp. 385-409). Os estudos do autor sobre a matéria foram inicialmente apresentados na obra "Crime and Punishment: An Economic Approach", in Journal of Political Economy, vol. 76, 1968, pp. 169-217. 
= P.1/p). Por exemplo, caso o benefício esperado pelo agente ao cometer determinada infração seja de $\mathrm{R} \$ 30.000,00$ (trinta mil reais) e a probabilidade de que a infração seja descoberta seja de 1/3 (um terço), a sanção deve corresponder ao benefício esperado multiplicado por três, ou seja, $\mathrm{R} \$ 90.000,00$ (noventa mil reais). Isso porque, caso a sanção seja inferior a esse valor, um agente racional concluirá que os ganhos potenciais decorrentes da prática superam o prejuízo esperado e continuará a ter incentivos para cometer o ato ilícito ${ }^{103}$.

Por esse modelo, a adequada dissuasão de crimes e práticas ilícitas pode ser obtida por uma combinação entre a magnitude da sanção e a probabilidade de detecção. Caso a probabilidade de detecção seja elevada, as sanções podem ser fixadas em patamar mais reduzido e, ainda assim, as práticas ilícitas serão coibidas. No entanto, caso a probabilidade de detecção seja baixa, as sanções terão que ser mais elevadas para que possam efetivamente desestimular a ocorrência de infrações.

O modelo acima descrito costuma ser aplicado à análise da prevenção da prática de cartel, reconhecendo-se que, por se tratar de infração caracterizada pelo sigilo, com baixa probabilidade de detecção ${ }^{104}$, a "sanção ótima" que pretenda coibir adequadamente a conduta em tese deve ser superior ao benefício esperado pelos infratores ${ }^{105}$.

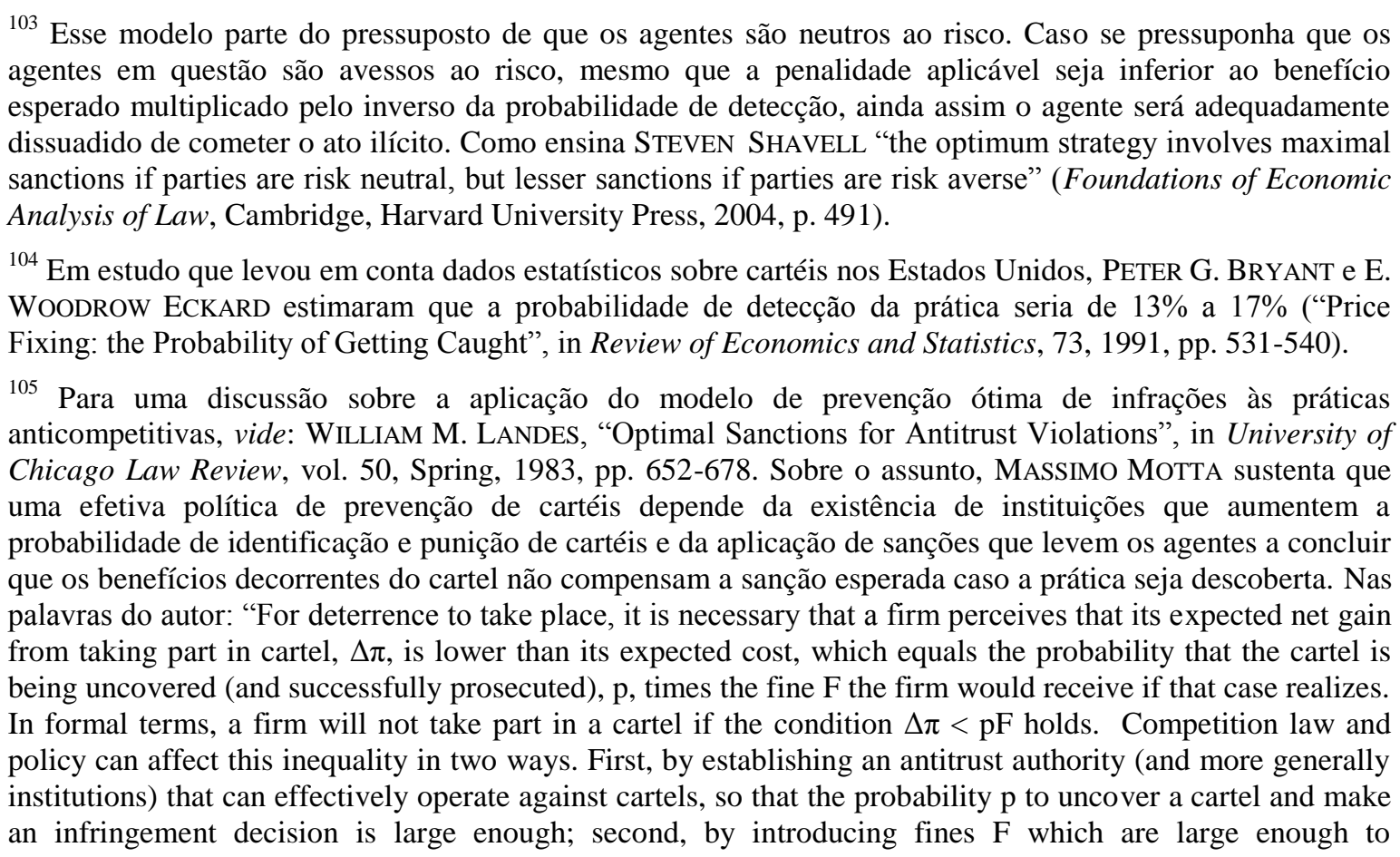


Examinando-se a responsabilidade civil em matéria antitruste à luz do modelo acima descrito, a doutrina concorrencial conclui que as ações de cobrança de indenização por parte dos prejudicados podem reforçar os mecanismos de prevenção de cartéis e, desse modo, contribuir para a dissuasão da prática. Isso pelas seguintes razões:

i) as demandas aumentam a probabilidade de detecção de cartéis, por incentivarem os próprios prejudicados a denunciarem a prática e a ingressarem em juízo para fazê-la cessar e obter reparação;

ii) as demandas individuais permitem uma divisão de tarefas entre os particulares e as autoridades de defesa da concorrência, viabilizando que as autoridades poupem recursos que podem então ser empregados na detecção de outros cartéis e práticas anticompetitivas, o que também aumenta a probabilidade geral de detecção; e

iii) as demandas aumentam a sanção jurídica esperada em caso de detecção do cartel, pois, além de estarem sujeitos às sanções administrativas e criminais, os infratores também podem ser obrigados a pagar indenizações aos prejudicados em caso de condenação $^{106}$.

No Brasil, embora se reconheça que a prevenção de cartéis é tarefa precípua do sistema de controle de condutas a cargo do CADE e das autoridades criminais, a doutrina também sustenta que as ações de responsabilidade civil podem dar sua

discourage prospective cartel members to engaging in the cartel" (On Cartel Deterrence and Fines in the EU, European University Institute, Florence and Università di Bologna, October 12, 2007, disponível em: $<\mathrm{http}: / /$ www.barcelonagse.eu/tmp/pdf/motta_carteldeterfines.pdf $>$. Acesso em: 23.mar.2013, p. 5).

${ }^{106}$ Veja-se: "There are various reasons why policy-makers find private actions attractive, and hence have sought to facilitate them. One is that they save taxpayers' money. Competition authorities have limited budgets and must prioritize their enforcement actions. (...) Another reason for policy-makers to encourage private damages actions is that they contribute to the deterrence of anti-competitive practices. Effective deterrence enhances competition without costing taxpayers much money. Nowadays, hefty fines, and possible prisons sentences for individuals, already constitute a strong deterrent (though apparently still not sufficiently strong, judging by the numbers of cartels still being uncovered every year - see Chapter 9). The prospect of having to pay damages on top of the fines may further dampen any enthusiasm to form cartels." (GUNNAR Niels, Helen Jenkins e James KAVANAGH, Economics for Competition Lawyers, cit., p. 493). 
contribuição na tarefa de coibir a prática. Nesse sentido, veja-se o entendimento de RoBerto Augusto CASTEllanOS PFEIFFER ${ }^{107-108}$ :

“A propositura de ações de indenização possui dupla função. Em primeiro lugar, a de recompor a esfera patrimonial dos consumidores que tiveram os seus interesses econômicos lesados. Em segundo lugar possuem uma função dissuasória, ou seja, desestimulam a prática de infração contra a ordem econômica".

De igual modo, BRUNO OlIVEIRA MAGGI, em dissertação de mestrado sobre o assunto, defende que ${ }^{109-110}$ :

"as indenizações civis (...) podem auxiliar nessa conta, pois aumentariam o valor de M, previsto na fórmula acima, desequilibrando o resultado contra os cartelistas. Ademais, surgem como uma variável com grau de imprevisibilidade muito maior que o das penas administrativas, pois para estimar as perdas, os cartelistas precisam levar em consideração todos os eventuais pedidos de indenização iniciados pelos lesados e o valor das condenações, que serão definidos caso a caso. Assim, mesmo considerando apenas o caráter reparatório da indenização, sua contribuição para o desestímulo da prática de cartéis é imensa”.

Após estabelecidas as premissas com relação ao debate doutrinário acerca do papel da responsabilidade civil em matéria antitruste, os capítulos subsequentes

107 Defesa da Concorrência e Bem-Estar do Consumidor, Tese de Doutorado, Faculdade de Direito da Universidade de São Paulo, 2010, p. 250.

108 No mesmo sentido, TÉRCIO SAMPAIO FERRAZ JÚNIOR, comentando o sistema norte-americano, também chama a atenção para a complementariedade dos objetivos de compensação dos danos e de "enfrentamento do poder econômico" em matéria de ações indenizatórias: "E nos Estados Unidos o tema vem provocando discussões no sentido de aprimorar os mecanismos usuais em private litigation que conduzam a uma descentralização do enforcement como instrumento ancilar e eficaz no fortalecimento da ação oficial no enfrentamento do poder econômico, sobretudo em sede de condutas cartelizadoras. Assim, nos Estados Unidos, por exemplo, embora ações privadas estejam usualmente focadas na reparação de danos em termos de compensação, já existem muitos processos dos quais resultam condenações que são três vezes maiores que os danos estritamente privados, pois o perfil do sistema norte-americano está antes no encorajamento às vítimas para peticionar e defender seus direitos como "compensação" da própria conduta anticompetitiva. Há, nesses termos, um ostensivo e real empenho, teórico e prático, na literatura e na jurisprudência norteamericana e europeia, em estabelecer um relacionamento eficaz entre prejuízo à concorrência e danos privados" ("Direito da Concorrência e Enforcement Privado na Legislação Brasileira", cit., p. 13).

109 O Cartel e seus Efeitos no Âmbito da Responsabilidade Civil, Dissertação de Mestrado, Faculdade de Direito da Universidade de São Paulo, 2010, p. 181.

${ }^{110}$ Em sentido semelhante, veja-se a posição de ANDRÉ MARQUES FRANCISCO: “(...) as ações privadas terão a função não apenas de prover efetiva reparação aos agentes atingidos pelas práticas anticoncorrenciais, mas também a de efetivamente complementar a função repressiva promovida pela atividade estatal. No atual contexto legislativo, a utilização das ações privadas em matéria antitruste se mostra necessária como forma de complementar a função repressiva do enforcement do antitruste" (Responsabilidade Civil por Infração da Ordem Econômica, Dissertação de Mestrado, Faculdade de Direito da Universidade de São Paulo, 2014, p. 70). 
examinarão a disciplina da reparação de danos decorrentes da prática de cartel no direito estrangeiro (direito federal norte-americano e direito comunitário europeu) e no direito brasileiro. 


\section{RESPONSABILIDADE POR DANOS DECORRENTES DA PRÁTICA DE CARTEL NO DIREITO ESTRANGEIRO}

O presente capítulo abordará a disciplina da reparação de danos decorrentes de cartel no direito estrangeiro. Serão estudados os modelos de reparação de danos vigentes no direito federal dos Estados Unidos - país em que as ações indenizatórias em matéria antitruste se desenvolveram há mais tempo - e no direito comunitário da União Europeia.

\subsection{Estados Unidos}

Qualquer estudo de direito comparado sobre a responsabilidade civil por cartel deve necessariamente examinar as regras vigentes nos Estados Unidos. Trata-se do país que possui a mais antiga tradição em matéria de ações indenizatórias por infrações concorrenciais e no qual até hoje a aplicação do direito antitruste se dá predominantemente por meio de ações movidas por particulares. Enquanto na maior parte dos ordenamentos a legislação concorrencial é aplicada principalmente por órgãos governamentais especializados - como ocorre, por exemplo, no Brasil e na União Europeia - estima-se que nos Estados Unidos cerca de 90\% (noventa por cento) da aplicação da legislação antitruste seja feita por meio de ações individuais movidas por particulares ${ }^{111}$. Os principais elementos do direito federal norte-americano ${ }^{112}$ serão examinados a seguir.

\footnotetext{
${ }^{111}$ HERBERT HOVEMKAMP, escrevendo sobre a aplicação do direito antitruste nos Estados Unidos, esclarece que "the private antitrust action continues to be the principal mechanism by which antitrust laws are enforced. As many as 90\% of antitrust cases are brought by private plaintiffs" (Federal Antitrust Policy..., cit., p. 593).

${ }^{112}$ Sobre a estrutura do direito norte-americano, RENÉ DAVID esclarece: "O direito dos Estados Unidos pertence, pela sua própria estrutura, à família da common law. (...) O direito, quer para um jurista americano, quer para um jurista inglês, é concebido essencialmente sob a forma de um direito jurisprudencial; as regras formuladas pelo legislador, por mais numerosas que sejam, são consideradas com uma certa dificuldade pelo jurista que não vê nelas o tipo normal da regra do direito; estas regras só são verdadeiramente assimiladas ao sistema de direito americano quando tiverem sido interpretadas e aplicadas pelos tribunais e quando se tornar possível, em lugar de se referirem a elas, referirem-se às decisões judiciárias que as aplicaram. (...) O direito norte-americano tem, por consequência, de maneira geral, uma estrutura análoga à da common law. No entanto, apenas se trata de uma observação geral, e desde que se enfoque mais de perto o problema, descobrem-se, entre o direito americano e o direito inglês, múltiplas diferenças de estrutura, algumas das quais são verdadeiramente substanciais e não podem ser ignoradas. Sobretudo uma diferença deve ser estudada, porque é fundamental: é a distinção que se faz nos Estados Unidos, mas não na Inglaterra, entre direito federal e direito dos Estados. (...) A Inglaterra ignora a noção de direito federal. Os Estados Unidos são, pelo contrário, um Estado federal, no qual se apresenta inevitavelmente, desde o início, uma questão primordial: a das atribuições respectivas das autoridades federais e dos Estados" (Os Grandes Sistemas do Direito Contemporâneo, $3^{\mathrm{a}}$ ed., São Paulo, Martins Fontes, 1996, pp. 367-368).
} 


\subsubsection{Panorama da disciplina dos cartéis no direito federal norte-americano}

No direito federal norte-americano, a prática de cartel é proibida pelo $\S 1^{\circ}$ do Sherman Act, que declara ilegal "qualquer contrato, combinação na forma de truste ou outra forma, ou conspiração, em restrição ao comércio entre os Estados, ou com nações estrangeiras" $" 113$

A prática de cartel é considerada ilícita "per se" nos Estados Unidos, o que equivale a dizer que basta a demonstração da ocorrência da conduta para que seja considerada ilícita, independentemente da análise das condições do mercado relevante ou do exame de eventuais efeitos benéficos da prática que possam contrabalancear os efeitos anticompetitivos $^{114}$. Além de ensejar a reparação dos danos causados aos prejudicados, o cartel também pode resultar em punição na esfera criminal, ficando os responsáveis sujeitos a penalidades pecuniárias e a penas de prisão $^{115}$.

\subsubsection{Ações indenizatórias por infrações concorrenciais no direito federal norte- americano: condenação ao pagamento do triplo dos prejuizos ("treble damages")}

A regra básica referente à reparação de danos por práticas anticompetitivas no direito federal norte-americano é estabelecida pelo $\S 4^{\circ}$ do Clayton Act, que dispõe que "qualquer pessoa que tenha sofrido danos em seus negócios ou propriedade em razão de qualquer prática proibida pela legislação antitruste pode ajuizar ação (...) e deve ser restituída pelo triplo dos prejuízos sofridos, além dos custos do processo, incluindo honorários de advogado em patamares razoáveis." "116.

\footnotetext{
113 Tradução livre do original: "Every contract, combination in the form of trust or otherwise, or conspiracy, in restraint of trade or commerce among the several States, or with foreign nations, is declared to be illegal".

114 O estabelecimento de uma regra de ilicitude "per se" para determinadas práticas anticompetitivas, tais como os cartéis, costuma ser justificado na doutrina norte-americana pelo duplo objetivo de: (i) conferir previsibilidade com relação à ilicitude de determinadas práticas; e (ii) facilitar o trabalho dos juízes no julgamento de referidas condutas, eliminando a necessidade de exame detalhado dos efeitos potenciais em cada caso concreto. Sobre o assunto, vide: ERNEST GELLHORN e WiLliam E. Kovacic, Antitrust Law and Economics in a Nutshell, $4^{\text {th }}$ ed., St. Paul, Minnesota, West Publishing, 1994, pp. 165-166.

115 Einer Elhauge e Damien Geradin, Global Competition Law and Economics, Portland, Hart Publishing, 2007, p. 7-8.

116 Tradução livre do original: "Except as provided in subsection (b) of this section, any person who shall be injured in his business or property by reason of anything forbidden in the antitrust laws may sue (...) and
} 
O exame do referido dispositivo permite identificar o principal traço distintivo do sistema norte-americano de reparação de danos por práticas anticompetitivas: a previsão de condenação ao pagamento de valor equivalente ao triplo dos prejuízos sofridos pelos prejudicados ("treble damages") ${ }^{117}$.

Trata-se de regra típica do sistema norte-americano, que constitui importante incentivo à aplicação da lei concorrencial e é apontada como um dos principais fatores que explicam a elevada quantidade de demandas indenizatórias nos Estados Unidos $^{118}$.

Para compreender a aplicação dos "treble damages", convém esclarecer que no direito norte-americano, ao contrário do que se passa no direito brasileiro, a imposição de condenações no âmbito civil em montante superior aos danos sofridos não é incomum. Em matéria de "torts", chamados "punitive damages", os quais representam uma condenação, em âmbito civil, aplicada aos autores de determinadas práticas ilícitas consideradas graves, com o intuito de punir e desestimular o ofensor (e outras pessoas) a cometer novas infrações no futuro ${ }^{120}$.

shall recover threefold the damages by him sustained, and the cost of suit, including a reasonable attorney's fee".

${ }^{117}$ A análise do $\S 4^{\circ}$ do Clayton Act também permite identificar outros requisitos para a reparação de danos por práticas anticompetitivas, quais sejam: (i) o ofendido deve ser uma "pessoa" ("person"), o que inclui as pessoas físicas, empresas e associações (o Clayton Act também permite que o governo federal e os estados ajuízem demandas para reparação de danos sofridos); (ii) a violação deve envolver os "negócios ou propriedade" ("business or property") do ofendido; e (iii) a responsabilização decorre de prática que seja proibida pela "legislação antitruste" ("antitrust law"), o que inclui, dentre outros diplomas legais, o Sherman Act, o Clayton Act e o Robinson-Patman Act. Sobre a interpretação dos termos do $\S 4^{\circ}$ do Clayton Act, vide: American Bar Association, Antitrust Law Developments, vol. I, $6^{\text {th }}$ ed., ABA Section of Antitrust Law, 2007, pp. 810-814.

${ }^{118}$ De acordo com EINER ELHAUGE e DAMIEN GERADIN, "the most distinctive feature of US antitrust enforcement is that it provides actions for treble damages that mean government enforcement is supplemented, and in many areas dominated, by private suits" (Global Competition Law and Economics, cit., p. 8).

119 Como esclarece ANA FRAZÃo, o termo "torts" "não encontra correspondência no direito romanogermânico, já que não significa propriamente atos ilícitos, mas sim condutas ensejadoras de responsabilidade extracontratual" ("Principais Distinções e Aproximações de Responsabilidade Civil nos Modelos Francês, Alemão e Anglo-Saxão", in OCTÁvio LUIZ RODRIGUES JÚNIOR, GLADSTON MAMEDE e MARIA VITAL ROCHA (coord.), Responsabilidade Civil Contemporânea: em Homenagem a Sílvio de Salvo Venosa, São Paulo, Atlas, 2011, p. 755).

120 "Punitive damages are awarded based on the nature of a defendant's wrongful conduct and, by definition, may bear little relationship to the extent of a plaintiff's injuries. As a general proposition, punitive damages are damages awarded to punish a person for extreme or outrageous acts and to deter that person and others from similar conduct in the future. These dual goals - punishment and deterrence - are similar to those of 
Embora possam ser considerados como uma espécie de "punitive damages", os "treble damages" aqui discutidos constituem instituto específico previsto no Clayton Act para as hipóteses de indenização em matéria antitruste, sendo entendimento majoritário da jurisprudência que um autor não pode cumular, em face da mesma conduta, pedidos de condenação por "treble damages" e por "punitive damages",

A regra do "treble damages" do direito antitruste é objeto de crítica por parcela da doutrina norte-americana, havendo quem sustente que a perspectiva de receber pagamento em valor equivalente ao triplo do prejuízo sofrido teria como consequência a proliferação de demandas indenizatórias, muitas das quais infundadas, o que resultaria em um nível excessivo de prevenção ("overdeterrence"). Nesse contexto, parcela da doutrina defende a abolição da regra dos "treble damages" e sua substituição por um sistema em que a indenização seja calculada de acordo com a extensão do dano ( "single damages”) ${ }^{122}$.

Por outro lado, os defensores da regra de condenação pelo triplo costumam destacar sua importância como elemento de desestímulo à prática de infrações concorrenciais $^{123}$. O fato é que, apesar de ser alvo de críticas por parcela da doutrina, trata-

criminal law. Because punitive damages are found in civil law but are penal in nature, this doctrine has been characterized as "quasi-criminal"' (American Bar Association, Punitive Damages and Business Torts: A Practitioners’ Handbook, ABA Section of Antitrust Law, 1998, pp. 2-3).

121 "Treble damages are a species of punitive damages, but there are significant distinctions between these and punitive damages recoverable at common law. (...) The few courts that have explicitly addressed whether antirust damages and tort punitive damages are duplicative have refused to award both treble and punitive damages. They have required, instead, that the plaintiff elect one package of damages (the Clayton Act's threefold actual damages) or the other (tort's actual plus punitive damages)" (American Bar Association, Punitive Damages and Business Torts: A Practitioners' Handbook, cit., pp. 18-23).

${ }^{122}$ Sobre o assunto, vide: EdWARD D. CAVANAGH, "Detrebling Antitrust Damages: An Idea Whose Time Has Come?", in Tul. Law Review, 61, 777, 1987; FrANK H. EASTERBROOK, "Detrebling Antitrust Damages", in Journal of Law and Economics, vol. 28, n. 2, 1985, p. 445; e WiLliam BREIT e KenNETH G. ElZINGA, "Private Antitrust Enforcement: The New Learning", in Journal of Law and Economics, vol. 28, n. 2, 1985, p. 405.

123 RoBert H. LANDE, em estudo empírico que analisou 40 (quarenta) casos envolvendo pedidos de indenização julgados nos Estados Unidos, defende enfaticamente o modelo norte-americano de reparação de danos por práticas anticompetitivas, em especial a regra de condenação pelo triplo dos prejuízos. O autor sustenta que o modelo tem sido eficaz na prevenção de práticas ilícitas e na compensação às vítimas, protegendo a economia norte-americana contra os cartéis internacionais, além de poupar recursos dos contribuintes por permitir que parcela significativa dos custos e riscos da aplicação da lei concorrencial sejam arcados pelos particulares diretamente interessados e não por agências governamentais. $\mathrm{O}$ autor também defende que as condenações em triplo são necessárias para compensar os prejudicados pelos juros (que normalmente não incidem antes do julgamento), pelas dificuldades para apuração dos danos, pelo tempo despendido no processo e outros prejuízos que não são passíveis de indenização, como a ineficiência alocativa gerada pelas infrações concorrenciais ("Benefits of Private Enforcement: Empirical Background", in Albert A. Foer e Jonathan W. Cuneo (org.), The International Handbook of Private Enforcement of Competition Law, cit., pp. 7-9). 
se de regra sedimentada na cultura jurídica antitruste dos Estados Unidos, não havendo qualquer sinal de que tal norma deva ser revogada ou modificada num futuro próximo.

Tanto é assim que, em 2 de abril de 2007, a Comissão para Modernização do Direito Antitruste ("Antitrust Modernization Commission”), criada por lei alguns anos antes, apresentou ao Presidente e ao Congresso dos Estados Unidos relatório contendo análise abrangente do direito antitruste norte-americano. $\mathrm{O}$ relatório contém diversas recomendações de modificações e aperfeiçoamentos com relação a vários aspectos do direito antitruste, tendo, não obstante, recomendado a manutenção do sistema de indenização em triplo, por considerá-lo adequado aos objetivos de prevenção de infrações concorrenciais e reparação dos prejuízos sofridos pelos prejudicados ${ }^{124}$.

\subsubsection{Interação entre as ações indenizatórias e o programa de leniência: exceção à regra de "treble damages"}

$\mathrm{O}$ direito federal norte-americano prevê uma importante exceção à regra geral de condenação pelo triplo: o membro do cartel que tenha firmado acordo de leniência com as autoridades ${ }^{125}$, diferentemente dos demais membros do cartel, fica sujeito apenas ao pagamento de indenização no montante do prejuízo causado ("single damages") em decorrência dos produtos ou serviços que ele mesmo tenha vendido com sobrepreço ao autor da demanda ${ }^{126}$.

Cabem, aqui, algumas considerações sobre a interação entre as ações indenizatórias por danos decorrentes de práticas anticompetitivas e o programa de

\footnotetext{
${ }^{124}$ Veja-se, a respeito, o seguinte trecho do relatório: "The Commission recommends no change to the fundamental remedial scheme of antitrust laws: the treble damage remedy and plaintiff's ability to recover attorney's fees. On balance, the current scheme appears to be effective in enabling plaintiffs to pursue litigation that enhances the deterrence of unlawful behavior and compensates victims" (Antitrust Modernization Commission..., cit., p. vi).

${ }^{125}$ No sistema norte-americano, apenas o primeiro membro do cartel que denunciar a infração às autoridades tem direito aos benefícios do programa de leniência, modelo que também é aplicado no Brasil.

${ }^{126}$ A regra foi introduzida pelo $\S 213$ (a) do "Antitrust Criminal Penalty Enhancement and Reform Act" ("ACPERA"): "(...) in any civil action alleging a violation of section 1 or 3 of the Sherman Act, or alleging a violation of any similar State law, based on conduct covered by a currently effective antitrust leniency agreement, the amount of damages recovered by or on behalf of a claimant from an antitrust leniency applicant who satisfies the requirements of subsection (b), together with the amounts so recovered from cooperating individuals who satisfy such requirements, shall not exceed that portion of the actual damages sustained by such claimant which is attributable to the commerce done by the applicant in the goods or services affected by the violation".
} 
leniência. Embora se reconheça, conforme exposto acima, que as ações de indenização de modo geral reforçam a dissuasão de práticas anticompetitivas, há um aspecto apontado pela doutrina em relação ao qual a responsabilidade civil pode ter efeito negativo ou ambíguo sobre a política de defesa da concorrência.

Com efeito, muitos ordenamentos, incluindo o Brasil, os Estados Unidos e a União Europeia, possuem os chamados programas de leniência, por meio dos quais empresas ou indivíduos que confessem a participação em cartéis e outras práticas anticompetitivas, bem como colaborem com a investigação e identificação dos demais infratores, têm direito a benefícios, tais como a redução ou isenção de penalidades nas esferas administrativa e criminal. Os programas de leniência são considerados um importante instrumento na política de defesa da concorrência, justamente por aumentarem a probabilidade de detecção de infrações e, nos termos do modelo teórico descrito no capítulo 3, acima, contribuírem para a dissuasão de práticas ilícitas ${ }^{127}$.

No entanto, a confissão da conduta anticompetitiva tende a deixar os signatários do acordo de leniência mais expostos às ações de indenização. Por tal razão, as ações de indenização podem em tese resultar em desestímulo à celebração de acordos de leniência, prejudicando a efetividade desse instrumento de detecção de cartéis e outras infrações.

Por conta disso, há atualmente debate na doutrina estrangeira sobre a necessidade e conveniência de previsão de mecanismos que atenuem os efeitos da responsabilidade civil sobre os signatários do acordo de leniência - tais como a limitação da responsabilidade - de modo a evitar que as ações indenizatórias constituam desestímulo à celebração de acordos de leniência ${ }^{128}$.

\footnotetext{
127 Sobre o assunto, vide: OCDE, Plea Barganing/Settlement of Cartel Cases, 2006, disponível em: <http://www.oecd.org/competition/cartels/40080239.pdf>. Acesso em: 4.abr.2013.

${ }^{128}$ Sobre a interação entre as ações de indenização e acordos de leniência, GIORGIO MONTI escreve que "courts are not bound by leniency schemes. So a party that settles with the commission may still face private lawsuits. This problem is particularly poignant because it creates a risk that facilitating private litigation diminishes the incentive for parties to make leniency application (e.g., when the reduction of a fine through leniency programmes is less than the damages that the party is likely to have to pay). Accordingly, the Commission is investigating how to reconcile leniency programmes with damages claims" (EC Competition Law, New York, Cambridge University Press, 2007, p. 437).
} 
Nesse contexto, a exceção à regra dos "treble damages" aplicável aos signatários do acordo de leniência nos Estados Unidos tem o propósito de conferir maiores incentivos para que os infratores celebrem acordo de leniência e colaborem com a investigação do cartel e identificação dos demais participantes.

\subsubsection{Exigência de ocorrência de "dano concorrencial" ("antitrust injury")}

A interpretação literal do $\S 4^{\circ}$ do Clayton Act poderia, em uma primeira análise, levar à conclusão de que qualquer pessoa que tenha sofrido qualquer espécie de dano em razão de uma prática proibida pela legislação antitruste teria direito a receber pagamento em triplo. Os tribunais norte-americanos, contudo, foram paulatinamente estabelecendo limitações jurisprudenciais à linguagem abrangente do dispositivo legal.

Uma importante restrição estabelecida pelos tribunais foi a exigência de que o autor de uma demanda somente tem direito a indenização caso tenha sofrido o que se convencionou chamar de "dano concorrencial" ( "antitrust injury”), ou seja, um dano que decorra dos aspectos anticoncorrenciais da prática questionada ${ }^{129}$.

Essa exigência é importante pelo fato de que, em muitos casos, as práticas de mercado possuem, simultaneamente, tanto aspectos anticompetitivos como aspectos benéficos ou neutros do ponto de vista concorrencial.

Tome-se como exemplo uma concentração entre duas empresas. Por um lado, a concentração pode viabilizar a redução de custos e o aproveitamento de sinergias, fazendo com que a empresa resultante da operação seja mais eficiente. Nesse caso, independentemente da licitude ou ilicitude da concentração, um concorrente que alegasse que perdeu mercado em decorrência da maior eficiência da empresa não preencheria a exigência do "dano concorrencial", pois o dano alegado resultaria de um aspecto da

\footnotetext{
${ }^{129}$ De acordo com a Suprema Corte norte-americana, o autor da demanda deve provar que o dano pleiteado constitui "antitrust injury, which is to say injury of the type the antitrust laws were intended to prevent and that flows from that which makes defendants' acts unlawful. The injury should reflect the anticompetitive effect either of the violation or of anticompetitive acts made possible by the violation" (Brunswick Corp v Pueble Bowl-O-Mat, 429, US 477, 489, 1977).
} 
concentração favorável à competição no mercado envolvido ${ }^{130}$. Por outro lado, caso a operação viabilizasse o exercício de poder de mercado, haveria a possibilidade de efeitos anticompetitivos, como a fixação de preços mais elevados. Nessa hipótese, um consumidor que alegasse ter pagado sobrepreço em virtude do poder de mercado da empresa resultante da concentração preencheria, em tese, o critério do "dano concorrencial" e teria direito a ser ressarcido, pois o prejuízo alegado decorreria de um aspecto anticompetitivo da prática questionada.

Pela mesma razão, a Suprema Corte entende que também se verifica o chamado "dano concorrencial" na hipótese de clientes ou consumidores pleitearam ressarcimento por sobrepreço pago em decorrência da prática de cartel ${ }^{131}$.

Em síntese, a doutrina do "dano concorrencial" serve ao propósito de selecionar, como objeto de reparação civil na esfera antitruste nos termos do $\S 4^{\circ}$ do Clayton Act, apenas aqueles danos que decorram de práticas que tenham por objeto a restrição da concorrência no mercado, tais como os cartéis ${ }^{132}$.

\footnotetext{
${ }^{130}$ A exigência de "antitrust injury" foi estabelecida inicialmente em casos envolvendo concentração entre empresas. O leading case sobre o assunto envolvia demanda na qual um empresário que explorava uma pista de boliche pleiteava indenização por ter supostamente deixado de ganhar mercado em virtude de aquisição, por concorrente, de centros de boliche que estavam em vias de ir à falência. A Suprema Corte julgou que, independentemente da licitude ou não da referida aquisição, o dano pleiteado pelo autor decorria justamente do aumento da competição após a operação, razão pela qual o autor não teria direito à indenização pleiteada (Brunswick Corp v Pueble Bowl-O-Mat, 429, US 477, 489, 1977).

${ }^{131}$ A jurisprudência da Suprema Corte norte-americana exige a demonstração da existência de "dano concorrencial" inclusive em casos envolvendo infrações que, como os cartéis, são consideradas ilícitas "per $s e$ ". Veja-se: "The per se rule is a method of determining whether $\S 1$ of the Sherman Act has been violated, but it does not indicate whether a private plaintiff has suffered antitrust injury and thus whether he may recover damages under $\S 4$ of the Clayton Act" (Atlantic Richfield Co v USA Petroleum, 495, US 328, 334, 1990).

${ }^{132}$ Nas palavras de Herbert HOVEMKAMP: "Properly used, the antitrust injury doctrine serve the useful function of requiring the plaintiff to show at an early stage the precise relationship between its injury (or threatened injury) and the amount of competition in the market. The result may expose those complaining of a rival's increased efficiency; it may also serve to uncover breach of contract claims or other common law claims disguised as antitrust suits. Although many plaintiffs may have been wronged in some abstract or common law sense, or perhaps even by violation of some other federal statute, they do not have antitrust claim unless their injury results from a practice designed to increase price, decrease output, or eliminate rivals with monopoly as a goal" (Federal Antitrust Policy..., cit., p. 603).
} 


\subsubsection{Exigência de relação próxima do prejudicado com a infração concorrencial: a chamada "pass-on defense" $e$ a legitimidade de compradores diretos $e$ indiretos no direito norte-americano}

Outra exigência estabelecida pela jurisprudência norte-americana é que o prejudicado pela infração concorrencial tenha uma relação próxima - e não remota - com o causador do dano. Essa exigência atende à preocupação de identificar qual é o prejudicado que, por ter relação mais próxima com a infração, possui as melhores condições e incentivos para ajuizar a ação e, dessa forma, assegurar a aplicação da lei concorrencial ${ }^{133}$.

Um importante desdobramento dessa preocupação pode ser identificado no tratamento dado pela jurisprudência norte-americana à chamada "pass-on defense". Com efeito, os prejuízos causados pelas condutas anticompetitivas, em especial os cartéis, costumam se disseminar ao longo da cadeia produtiva do produto ou serviço afetado. Desse modo, um produtor que adquira determinado insumo a preços cartelizados tenderá, na medida do possível, a repassar o sobrepreço decorrente do cartel aos consumidores de seus próprios produtos, e assim por diante.

Nesse contexto, uma questão que se colocou diante dos tribunais norteamericanos diz respeito a quem teria legitimidade para ajuizar a ação de indenização: se os chamados compradores diretos ("direct purchasers") do cartel ou os compradores indiretos ("indirect purchasers") que, embora não tenham adquirido os produtos diretamente das empresas cartelizadas, sofreram prejuízos decorrentes do repasse do sobrepreço.

A solução adotada pela jurisprudência norte-americana favoreceu os compradores diretos. No julgamento do caso Hanover Shoe, a Suprema Corte decidiu que aquele que tenha adquirido um produto com sobrepreço tem direito a ser indenizado pela totalidade do sobrepreço pago (multiplicado por três, como visto), independentemente de ter repassado ou não parcela do prejuízo para os consumidores de seus próprios produtos.

\footnotetext{
${ }^{133}$ De modo geral, os tribunais norte-americanos entendem que não possuem legitimidade ativa os autores que tenham relação apenas indireta ou remota com o dano, tais como credores, empregados, administradores, acionistas ou fornecedores dos prejudicados pelas infrações antitruste. Por outro lado, os concorrentes e consumidores dos infratores, de modo geral, são considerados parte legítima para ajuizar a ação (American Bar Association, Antitrust Law Developments, cit., pp. 824-826).
} 
O fundamento para a solução adotada foi pragmático. Embora tenha reconhecido que, em muitos casos, o comprador direto tende a repassar parcela do sobrepreço para seus próprios clientes, a Suprema Corte entendeu que o acolhimento da "pass-on defense" prejudicaria a política de prevenção de infrações concorrenciais, por tornar demasiadamente complexa a prova da ocorrência do dano. Além disso, ponderou-se que os compradores finais do produto - no caso em questão, compradores de sapatos -, por terem sofrido prejuízo individual menor do que os compradores diretos, teriam menor interesse em pleitear o ressarcimento dos danos, o que, no limite, reduziria a eficácia da política de defesa da concorrência ${ }^{134}$.

Posteriormente, no julgamento do caso Illinois Brick, a Suprema Corte, aplicando os mesmos princípios do precedente Hanover Shoe, entendeu que os compradores indiretos - i.e., aqueles que não compraram diretamente da empresa monopolista ou cartelizada, mas sofreram danos decorrentes do repasse do sobrepreço pelo comprador direto -, não têm direito a qualquer indenização.

A Suprema Corte considerou, em primeiro lugar, que haveria risco de sobreposição e multiplicidade de indenizações ("multiple liability”) caso se conferisse legitimidade tanto para os compradores diretos como para os compradores indiretos. Além disso, a Suprema Corte também apresentou fundamentos de caráter pragmático para justificar a decisão. Entendeu-se que a tarefa de calcular e discriminar os danos sofridos por cada agente da cadeia produtiva seria demasiadamente complexa. Por fim, considerou-

\footnotetext{
${ }^{134}$ Veja-se o teor do julgado: "Even if it could be shown that the buyer raised his price in response to, and in the amount of, the overcharge, and that his margin of profit and total sales had not thereafter declined, there would remain the nearly insuperable difficulty of demonstrating that the particular plaintiff could not or would not have raised his prices absent the overcharge, or maintained the higher price had the overcharge been discontinued. Since establishing the applicability of the passing-on defense would require a convincing showing of each of these virtually unascertainable figures, the task would normally prove insurmountable. On the other hand, it is not unlikely that, if the existence of the defense is generally confirmed, antitrust defendants will frequently seek to establish its applicability. Treble damage actions would often require additional long and complicated proceedings involving massive evidence and complicated theories. In addition, if buyers are subjected to the passing-on defense, those who buy from them would also have to meet the challenge that they passed on the higher price to their customers. These ultimate consumers, in today's case, the buyers of single pairs of shoes, would have only a tiny stake in a lawsuit, and little interest in attempting a class action. In consequence, those who violate the antitrust laws by price-fixing or monopolizing would retain the fruits of their illegality because no one was available who would bring suit against them. Treble damage actions, the importance of which the Court has many times emphasized, would be substantially reduced in effectiveness" (Hanover Shoe, Inc. v United Machinery Corp., 392, US 481, 1968).
} 
se, a exemplo do decidido no caso Hanover Shoe, que a legislação antitruste tende a ser aplicada de modo mais efetivo caso se permita que os compradores diretos pleiteiem a totalidade do sobrepreço pago ${ }^{135}$.

\section{A regra estabelecida nos precedentes Hanover Shoe e Illinois Brick é} bastante criticada, por conferir a totalidade da indenização aos agentes que têm condições de repassar parcela ou até mesmo a integralidade do sobrepreço aos compradores dos seus produtos, e por deixar sem indenização os consumidores finais, que em muitos casos absorvem a maior parte ou a totalidade do sobrepreço ${ }^{136}$.

De qualquer modo, os efeitos do precedente Illinois Brick foram, de certa forma, neutralizados por diversas leis estaduais que, como resposta à decisão da Suprema Corte, conferiram legitimidade para que compradores indiretos possam pleitear indenização com fundamento na legislação estadual. Na prática, isso significa que as empresas condenadas por cartel nos Estados Unidos podem estar sujeitas a uma multiplicidade de indenizações, tanto em âmbito federal como na esfera estadual ${ }^{137}$.

\footnotetext{
${ }^{135}$ Illinois Brick v Illinois, 431, US 720, 1977.

${ }^{136}$ O parecer enviado ao Presidente e Congresso dos Estados Unidos pela Comissão para Modernização do Direito Antitruste recomenda a revisão da regra adotada nos casos Hanover Shoe e Illinois Brick e sua substituição por um sistema no qual tanto os compradores diretos como indiretos teriam legitimidade para pleitear indenização pelos prejuízos sofridos por práticas anticompetitivas. Veja-se: "(...) federal Illinois Brick/Hanover Shoe policy provides a 'windfall' to purchasers who have passed on an overcharge, while depriving any recovery at all to purchasers who actually bear the overcharge. Such a system that compensates the uninjured and denies recovery to the injured seems fundamentally unfair. The Commission recommends that Congress overrule the Supreme Court's decisions in Illinois Brick and Hanover Shoe to the extent necessary to allow both direct and indirect purchasers to recover for their injuries" (Antitrust Modernization Commission..., cit., p. vi).

${ }^{137}$ HERVERT HOVEMKAMP esclarece o seguinte: "Importantly, the existence of a state statute in no way limits or controls damage measurement under federal law. (...) Thus, a direct purchaser proceeding under federal law will be entitled to treble the entire monopoly overcharge, while the indirect purchaser proceeding under state law will be entitled to treble the overcharge that was passed on to it. At the margin, this regime produce six-fold rather than treble damages" (Federal Antitrust Policy..., cit., p. 622). Sobre o assunto, criticando os resultados decorrentes do precedente Illinois Brick e a posterior legislação estadual, J. THOMAS ROSCH escreve que "in response to Illinois Brick, some states have passed laws known as 'Illinois Brick repealers' that extend standing to indirect purchasers, including consumers. Such laws have had the effect, of course, of subjecting an antitrust defendant to liability from multiple lawsuits by direct purchasers and indirect purchasers and duplicative recoveries - just as the Supreme Court had feared. An antirust defendant's exposure thus has sometimes far exceeded treble-damages, which can put tremendous pressure on the defendant to settle a case regardless of its merit, and can lead to extortionate settlements" ("Designing a Private Remedies System of Antitrust Cases: Lessons Learned from the U.S. Experience", in Revue des Droits de La Concurrence, n. 4, 2011, pp. 79-86).
} 


\subsubsection{Prova e quantificação dos danos e demonstração do nexo causal no direito norte- americano}

A prova e quantificação dos danos causados por uma prática anticompetitiva costuma ser apontada como a tarefa mais complexa a ser enfrentada pelo demandante que pleiteie indenização. Em geral, a demonstração dos prejuízos envolve a comparação entre o que de fato se passou no mercado e aquilo que teria se passado na ausência da infração. No caso dos cartéis, por exemplo, a demonstração dos danos envolve a comparação entre o preço pago pelo prejudicado e o preço que deveria ter sido pago em um cenário hipotético em que o cartel não teria ocorrido ${ }^{138}$.

Reconhecendo tais dificuldades, que, no limite, poderiam inviabilizar a reparação dos danos decorrentes de cartéis e outras infrações concorrenciais, a jurisprudência norte-americana estabeleceu critérios relativamente flexíveis para a demonstração dos prejuízos. De modo geral, uma vez provada a ocorrência da infração, o padrão necessário para a demonstração e quantificação dos prejuízos é menos rigoroso ${ }^{139}$. A justificativa para tal flexibilização decorre da noção de que, caso se exigisse um padrão de prova muito elevado para a demonstração e quantificação dos danos, estar-se-ia permitindo que os infratores se beneficiassem do caráter sigiloso de sua própria conduta ${ }^{140}$.

Nesse contexto, admite-se que a demonstração e quantificação dos prejuízos seja feita por meio de inferências ou estimativas razoáveis, desde que tais estimativas não resultem na alegação de danos puramente especulativos ${ }^{141}$. No caso da quantificação do

\footnotetext{
${ }^{138}$ Segundo EINER ElHAUGE e DAMIEN GERADIN, "proving antitrust damages is often very difficult because they require a comparison of what actually happened to a but-for world that never occurred. Unless we gain the ability to observe parallel universes, Courts can never be certain just what would have happened in the but-for world" (Global Competition Law and Economics, cit., p.13).

${ }^{139}$ Segundo HERBERT HOVEMKAMP, "any system of antitrust enforcement that takes private actions seriously must permit plaintiffs to estimate damages by mechanisms that are reasonably within their reach. (...) The Supreme Court has responded to these difficulties by setting a relatively high standard for proof of the fact of an antitrust violation and resulting injury, but a lower standard for proof of the amount of damages" (Federal Antitrust Policy..., cit., p. 656).

${ }^{140}$ Veja-se, a respeito, o seguinte julgado da Suprema Corte norte-americana: “a defendant whose wrongful conduct has rendered difficult the ascertainment of the precise damages suffered by the plaintiff, is not entitled to complain that they cannot be measured with the same exactness and precision as would otherwise be possible" (Eastman Kodac Co v Southern Photo Materials Co, 273 US 359, 379, 1927).

${ }^{141}$ Sobre os critérios para prova dos danos adotados pela jurisprudência norte-americana: "In the first half of the twentieth century, the Supreme Court upheld three jury awards of antitrust damages notwithstanding arguments that the plaintiff had produced insufficient evidence to allow a jury to determine the amount of
} 
sobrepreço causado pelo cartel, os tribunais admitem uma variedade de critérios, tais como a comparação do preço pago com os preços vigentes antes da infração ("before and after method") ou com os preços praticados em um mercado comparável que não tenha sido afetado pelo cartel ( "yardstick method"), dentre outros ${ }^{142}$.

Por fim, com relação ao nexo de causalidade, o autor da demanda deve provar, como em qualquer pleito indenizatório, que os prejuízos sofridos foram consequência da infração concorrencial. Para tanto, não é necessário demonstrar que os prejuízos jamais teriam ocorrido na ausência da infração, mas apenas que a prática ilícita contribuiu significativamente para os prejuízos ou que, na ausência da infração, a probabilidade de ocorrência dos danos seria expressivamente menor ${ }^{143}$.

\subsubsection{Prescrição da pretensão indenizatória}

O prazo de prescrição para o ajuizamento de ação pleiteando reparação por danos causados por práticas anticompetitivas no direito norte-americano é de 4 (quatro) anos, iniciando-se a contagem do prazo a partir do momento em que a infração é cometida e os danos são causados. Ambos os requisitos são necessários para o início da contagem do prazo: infração e ocorrência do dano.

damages. The three cases, Eastman Kodak Co. v. Southern Photo Materials Co., Story Parchment Co. v. Paterson Parchment Paper Co., and Bigelow v. RKO Radio Pictures, remain the leading cases on the standard for proving antitrust damages. In each case, the defendant argued that the plaintiff's proof of the but-for world was too uncertain. In each case, the Court acknowledged the uncertainty involved in construing a but-for world, but rejected the arguments. The standard adopted set a low threshold of proof: evidence requiring the jury to engage in 'speculation or guesswork' to decide an amount of damages is insufficient, but the evidence allowing the jury to make a 'just and reasonable estimate' of the 'probable' amount, although only 'approximate', suffices” (American Bar Association, Proving Antitrust Damages: Legal and Economic Issues, $2^{\text {nd }}$ ed., ABA Section of Antitrust Law, 2010, p. 55).

142 Com relação aos critérios para demonstração e quantificação dos prejuízos: "Several different methodologies have been developed for proving damages. The 'before and after' theory compares a plaintiff's profits or prices it paid during the period of violation with profits paid prior to the beginning of the violation period or after its termination. The 'yardstick' approach compares profits earned or prices paid by a plaintiff with the corresponding data for a firm or in a market unaffected by the violation. In either case, the plaintiff is required to show that the two sets of time periods, firms, or markets are generally comparable except for the effect of the violation" (American Bar Association, Antitrust Law Developments, cit., pp. 840841).

${ }^{143}$ De acordo com a jurisprudência da Suprema Corte norte-americana, "it is enough that the illegality is shown to be a material cause of the injury; a plaintiff need not exhaust all possible alternative sources of injury in fulfilling his burden of proving a compensable injury" (Zenith Radio Corp v Hazeltine Research, Inc, 395 US 100, 1969). 
Dentre as hipóteses de suspensão do prazo prescricional, incluem-se as seguintes: (i) na pendência de procedimento civil ou criminal movido pelo governo dos Estados Unidos com o objetivo de investigar a prática anticompetitiva em questão, a ação privada poderá ser ajuizada até um ano após o encerramento da ação movida pelo governo; (ii) caso o infrator tenha mantido a infração sob sigilo ("fraudulent concealment"), o prazo prescricional somente se inicia no momento em que o prejudicado poderia razoavelmente ter tido ciência da infração; e (iii) no caso de infrações continuadas, tais como um cartel de longa duração, o prazo somente se inicia após a cessação da infração ${ }^{144}$.

\subsubsection{Outras particularidades: tutela coletiva por meio de "class actions" e inexistência de direito de regresso entre os membros do cartel condenados}

Outras características marcantes do sistema norte-americano de reparação de danos decorrentes da prática de infrações concorrenciais são as seguintes:

i) a legislação norte-americana possibilita que determinado grupo de pessoas que tenha sofrido danos em decorrência de práticas anticompetitivas possa, desde que preenchidos determinados requisitos, agregar os pleitos indenizatórios em uma única demanda, por meio das chamadas "class actions"145; a utilização das "class actions" em matéria antitruste costuma ser apontada como importante fator de dissuasão de práticas anticompetitivas, uma vez que a agregação dos pleitos, somada à regra de condenação pelo triplo, tem por consequência o pagamento de indenizações em valores bastante elevados ${ }^{146}$; e

ii) os membros do cartel são solidariamente responsáveis pelo pagamento dos danos decorrentes da prática (a chamada “joint and several liability”), de modo que os prejudicados podem optar por ajuizar a ação contra qualquer um dos infratores; a particularidade do sistema norte-americano é que não há direito de regresso ( "right of contribution") entre os membros do cartel, de modo que o membro que

\footnotetext{
${ }^{144}$ American Bar Association, Antitrust Law Developments, cit., pp. 858-872.

${ }^{145}$ No direito federal norte-americano, as “class actions" são previstas na regra 23 das "Federal Rules of Civil Procedure".

${ }^{146}$ LAWRENCE A. SUllivan e WARREN S. GRIMES esclarecem que "the aggregate damages, after trebling, produced damages well-beyond those awarded in most suits brought by individual claimants, providing a more substantial deterrent" (The Law of Antitrust..., cit. , p. 946).
} 
porventura tenha sido obrigado a pagar a integralidade da indenização não pode se voltar contra os demais infratores para cobrar a parcela que lhes caberia em virtude da participação no ato ilícito; essa regra costuma ser defendida por representar poderoso estímulo para que os infratores encerrem rapidamente o litígio por meio de acordos ${ }^{147}$, embora também seja criticada por supostamente viabilizar abusos por parte dos litigantes e estimular réus eventualmente inocentes a fazerem acordos com medo de serem obrigados a arcar sozinhos com o pagamento do triplo dos prejuízos totais causados pelo cartel ${ }^{148}$.

Examinados os principais aspectos do direito federal norte-americano, o item seguinte analisará brevemente o sistema de reparação de danos por cartéis e outras práticas anticompetitivas vigente no direito comunitário europeu.

\subsection{União Europeia}

No sistema europeu, as ações de indenização movidas por particulares em virtude de danos decorrentes de práticas anticompetitivas possuem papel bem menos destacado do que no direito norte-americano. Diferentemente do que ocorre nos Estados Unidos, a aplicação da lei concorrencial na União Europeia fica a cargo principalmente das autoridades administrativas de defesa da concorrência ${ }^{149}$.

\footnotetext{
${ }^{147}$ HERBERT HOVEMKAMP resume os argumentos em favor da regra, alegando que: "the no contribution rule (...) reduces the overall costs of antitrust enforcement by encouraging defendants to settle before the trial." (Federal Antitrust Policy..., cit., p. 593).

148 Por essas razões, o relatório da Comissão para Modernização do Direito Antitruste recomendou a modificação da regra: "Defendants are jointly and severally liable for alleged conspiracies. There is no right of contribution among defendants. There is also only a limited right of claim reduction when one or more defendants settle. The combined effect of these rules is that one defendant can be liable for nearly all of the damages caused by an antitrust conspiracy. Defendants thus face significant pressure to settle antitrust claims of questionable merit simply to avoid the potential for excessive liability. While the rules can maximize deterrence and encourage the resolution of claims through quick settlement, they can also overdeter conduct that may not be anticompetitive. (...) the Commission recommends that Congress enact legislation that would permit non-settling defendants to obtain a more equitable reduction of the judgment against them and allow for contribution among non-settling defendants" (Antitrust Modernization Commission..., cit., p. vi).

149 Como esclarece RICHARD WHISH, "historically within the EU public enforcement of competition law has been infinitely more important than private enforcement" (Competition Law, London, Oxford University Press, 2005, p. 290). No mesmo sentido, EINER ELHAUGE e DAMIEN GERADIN: "Unlike US antitrust law where remedies are generally obtained through court litigation, EC competition law is mostly enforced through administrative remedial mechanisms (...) An important feature of the European competition law enforcement system is that it is based upon administrative agencies whose powers go beyond the mere seeking of injunctive relief. (...) In contrast, judicial mechanisms (ie, before national courts) are traditionally left unexplored by plaintiffs" (Global Competition Law and Economics, cit., p. 40).
} 
De qualquer modo, esse tipo de ação tem ganhado importância na Europa nos últimos anos. Reconhecendo a importância das ações de indenização, a Comissão Europeia - órgão comunitário responsável pela aplicação do direito concorrencial - tem tomado uma série de iniciativas com o objetivo de fomentar a reparação dos danos sofridos pelos prejudicados, conforme será estudado nos itens abaixo.

\subsubsection{A reparação de danos decorrentes de práticas anticompetitivas no direito comunitário europeu}

A principal fonte do direito concorrencial europeu é o Tratado de Funcionamento da União Europeia, cujas normas são diretamente aplicáveis e devem ser observadas pelos Estados Membros. As regras comuns referentes à competição no âmbito da União Europeia atualmente estão previstas nos artigos 101 e 102.

Com relação ao cartel e outras práticas colusivas, o artigo 101 (1) proíbe "por serem incompatíveis com o mercado interno, quaisquer acordos entre empresários, decisões por associações de empresários e práticas concertadas que possam afetar o comércio entre Estados Membros e que tenham por objeto ou efeito a prevenção, restrição ou distorção da competição no âmbito do mercado interno, e em particular o seguinte: (a) fixar direta ou indiretamente preços de compra ou venda ou qualquer outra condição mercadológica; (b) limitar ou controlar a produção, mercados, desenvolvimento tecnológico ou investimentos; (c) dividir mercados ou fornecedores; (...)"150.

O Tratado de Funcionamento da União Europeia não contém qualquer disposição expressa assegurando o direito dos prejudicados a obterem indenização por prejuízos decorrentes de práticas anticompetitivas, o que, por um período, gerou dúvida se haveria um direito a indenização que decorresse diretamente do direito comunitário europeu.

\footnotetext{
${ }^{150}$ Tradução livre do original: "Article 81. (1) The following shall be prohibited as incompatible with the internal market: all agreements between undertakings, decisions by associations of undertakings and concerted practices which may affect trade between Member States and which have as their object or effect the prevention, restriction or distortion of competition within the internal market, and in particular those which: (a) directly or indirectly fix purchase or selling prices or any other trading conditions; (b) limit or control production, markets, technical development, or investment; (c) share markets or sources of supply; (...)".
} 
Essa dúvida foi esclarecida por decisão proferida em setembro de 2001 pela Corte Europeia de Justiça, que, no julgamento do caso "Courage", decidiu que os prejudicados por violações às disposições de direito concorrencial do Tratado de Funcionamento da União Europeia têm o direito de obter indenização pelos prejuízos sofridos, os quais devem ser pleiteados perante os tribunais dos Estados Membros ${ }^{151-152}$. Em julho de 2006, no julgamento do caso "Manfredi”, esse princípio foi confirmado pela Corte Europeia de Justiça, tendo ficado estabelecido que qualquer pessoa possui o direito de pleitear indenização por violações do direito concorrencial comunitário ${ }^{153}$.

\subsubsection{Iniciativas da Comissão Europeia com o objetivo de fomentar a responsabilidade civil em matéria concorrencial}

Como visto acima, embora esteja consolidado o entendimento de que as violações ao direito comunitário europeu geram direito dos prejudicados a receberem indenização pelos prejuízos sofridos, o fato é que tais pedidos de indenização devem ser pleiteados perante tribunais domésticos, ficando sujeitos às regras procedimentais e ao regime geral de responsabilidade civil dos respectivos Estados Membros.

\footnotetext{
${ }^{151}$ Veja-se o teor do julgado: "The full effectiveness of Article 85 of the Treaty and, in particular, the practical effect of the prohibition laid down in Article 85(1) would be put at risk if it were not open to any individual to claim damages for loss caused to him by a contract or by conduct liable to restrict or distort competition. Indeed, the existence of such a right strengthens the working of the Community competition rules and discourages agreements or practices, which are frequently covert, which are liable to restrict or distort competition. From that point of view, actions for damages before the national courts can make a significant contribution to the maintenance of effective competition in the Community. (...). However, in the absence of Community rules governing the matter, it is for the domestic legal system of each Member State to designate the courts and tribunals having jurisdiction and to lay down the detailed procedural rules governing actions for safeguarding rights which individuals derive directly from Community law (...)" (Case C-453/99, Courage Ltd v. Crehan [2001] ECR I-6297).

${ }^{152}$ No caso “Courage”, não obstante a Corte Europeia de Justiça tenha concluído que o autor poderia pleitear indenização pelos danos que alegava ter sofrido em virtude da suposta prática anticompetitiva, quando o caso retornou para julgamento de mérito perante o Poder Judiciário do Estado Membro da União Europeia em questão (Inglaterra), concluiu-se que a prática questionada pelo autor, relacionada a uma suposta restrição vertical no mercado de cervejas, não constituía violação ao Tratado de Funcionamento da União Europeia, razão pela qual o autor (Crehan) não recebeu qualquer indenização. Como esclarece RICHARD WHISH "after 13 years of litigation Crehan recovered no damages whatsoever; however, he made a crucial contribution to the important issue of private enforcement of competition law" (Competition Law, cit., p. 294).

153 “(...) any individual can claim compensation for the harm suffered where there is a causal relationship between that harm and an agreement or practice prohibited under Article 81 EC" (Case C-259-298/04, Vincenzo Manfredi v Lloyd Adriatico Assicurazioni SpA [2006], ECR I-6619).
} 
Nesse contexto, com o objetivo de assegurar a uniformização das legislações e fomentar a responsabilidade civil em matéria concorrencial, a Comissão Europeia editou nos últimos anos uma série de documentos sobre o assunto.

Em dezembro de 2005, a Comissão Europeia publicou um "Livro Verde"154 sobre o tema ("Green Paper on Damages Actions for Breach of the EC Antitrust Rules"), o qual identificava os principais obstáculos para a responsabilidade civil por infrações concorrenciais no âmbito da União Europeia e colocava em discussão alguns temas para aperfeiçoamento do sistema ${ }^{155}$.

Em abril de 2008, como resultado das inúmeras contribuições e respostas ao Livro Verde recebidas pela Comissão Europeia, foi publicado um "Livro Branco" sobre o assunto ("White Paper on Damages Actions for Breach of the EC Antitrust Rules") 156 . As principais recomendações apontadas no Livro Branco são as seguintes:

i) com relação à legitimidade para pleitear indenização, o Livro Branco esclarece que, como decorrência do julgado da Corte Europeia de Justiça no caso "Manfredi" segundo o qual "qualquer pessoa" pode pleitear a reparação por danos sofridos, os chamados compradores indiretos - i.e., aqueles que não negociaram diretamente com os infratores, mas sofreram danos em decorrência do repasse do sobrepreço possuem legitimidade para propor ações de indenização; ainda com relação à legitimidade, o Livro Branco recomenda a adoção de medidas para reforçar os mecanismos de tutela coletiva, tais como ações movidas por representantes dos prejudicados (e.g., associações de consumidores, órgãos estatais, associações comerciais, etc.) e demandas coletivas segundo o sistema de "opt-in", em que os prejudicados poderiam agregar os pleitos em uma única demanda;

\footnotetext{
154 Os chamados "livros verdes" são documentos publicados pela Comissão Europeia contendo reflexões sobre determinado assunto de interesse comunitário, com o objetivo de colher as opiniões dos interessados. Os chamados "livros brancos", por sua vez, podem ser emitidos na sequência de um "livro verde" e contém propostas de ação sobre o tema em questão em nível comunitário.

${ }^{155}$ Comissão Europeia, Green Paper..., cit.. p. 4.

156 Comissão Europeia, White Paper on Damages Actions for Breach of the EC Antitrust Rules, 2008, disponível em: <http://ec.europa.eu/competition/antitrust/actionsdamages/index.html>. Acesso em: 2.abr.2013.
} 
ii) o Livro Branco esclarece que as decisões condenatórias proferidas pela Comissão Europeia são vinculantes perante os tribunais dos Estados Membros com relação à existência de infração concorrencial; o Livro Branco apresenta recomendação no sentido de que as decisões definitivas por parte das autoridades nacionais de defesa da concorrência dos Estados Membros também possuam referido caráter vinculante;

iii) o Livro Branco reafirma o princípio da ampla reparação dos danos ("full compensation”), segundo o qual as vítimas devem ser ressarcidas em toda a extensão dos prejuízos sofridos, o que inclui tanto os danos emergentes como os lucros cessantes; com relação à quantificação dos danos sofridos, a Comissão Europeia, reconhecendo as dificuldades decorrentes do cálculo preciso dos prejuízos decorrentes de infrações concorrenciais, defende a ampla aceitação de métodos de cálculo baseados em estimativas, recomendando a elaboração de diretrizes não vinculantes sobre os critérios para quantificação dos danos, a serem levadas em conta pelos tribunais dos Estados Membros;

iv) o Livro Branco defende que a chamada "pass-on defense" - i.e., alegação de que o suposto prejudicado não tem direito a indenização nas hipóteses em que tenha repassado o sobrepreço para o elo seguinte da cadeia produtiva - deva ser aceita pelos tribunais dos Estados Membros, como forma de evitar o enriquecimento sem causa dos autores e a sobreposição de indenizações a serem pagas pelos réus;

v) com relação à prescrição, o Livro Branco, reconhecendo o caráter sigiloso dos cartéis e demais infrações concorrenciais, recomenda que os prazos prescricionais permaneçam suspensos até a cessação da infração, no caso de infrações continuadas, bem como durante o período no qual a vítima não tinha condições de ter ciência da infração; e

vi) com o objetivo de evitar que as ações de indenização constituam fator de desestímulo à celebração de acordos de leniência, o Livro Branco: (a) recomenda que seja conferida proteção quanto aos documentos sigilosos das empresas disponibilizados às autoridades no contexto da celebração de um acordo de leniência; e (b) coloca em discussão a possibilidade de ser editada norma limitando 
a responsabilidade civil de empresas ou indivíduos que sejam signatários de acordos de leniência, fazendo expressa ressalva de que, no exame da proposta, deverá ser levado em conta o potencial impacto de eventual norma nesse sentido sobre o direito dos prejudicados a obterem indenização ${ }^{157}$.

Posteriormente, foram tomadas as seguintes inciativas com relação a temas específicos discutidos no Livro Branco: (i) a Comissão Europeia encomendou estudo sobre os critérios para quantificação dos danos em matéria antitruste ${ }^{158}$ e, posteriormente, submeteu a consulta pública minuta de documento contendo orientações com relação aos danos causados por práticas anticompetitivas, bem como sobre os principais critérios de quantificação $^{159}$; e (ii) o Programa de Trabalho da Comissão Europeia de 2012 estabeleceu como metas assegurar a reparação de danos, aperfeiçoar a interação entre as esferas pública e privada na aplicação do direito concorrencial, bem como aperfeiçoar os mecanismos de tutela coletiva em matéria antitruste ${ }^{160}$.

\subsubsection{A Diretiva da União Europeia}

As iniciativas acima descritas culminaram na adoção pela Comissão Europeia, em 11 de junho de 2013, de uma Proposta de Diretiva com o objetivo de remover obstáculos à reparação de danos decorrentes de práticas anticompetitivas no âmbito da União Europeia ${ }^{161}$. Em 17 de abril de 2014 o texto da Diretiva foi aprovado pelo

\footnotetext{
${ }^{157}$ As demais recomendações do Livro Branco foram as seguintes: instituição de mecanismos para facilitar a obtenção de evidências por parte dos prejudicados; atenuação da exigência de prova de culpa por parte do infrator; e redução dos custos para o ajuizamento de ações de indenização (Comissão Europeia, White Paper..., cit., pp. 4-10).

158 Oxera Consulting, Quantifying Antitrust Damages: Towards Non-Biding Guidance for Courts - Study Prepared for the European Commission, 2009, disponível em: <http://ec.europa.eu/competition/publications/>. Acesso em: 7.abr.2013.

159 Comissão Europeia, Draft Guidance Paper - Quantifying Harm in Actions for Damages Based on Breaches of Article 101 or 102 of the Treaty on the Functioning of the European Union, 2011, disponível em: <http://ec.europa.eu/competition/consultations/2011_actions_damages/draft_guidance_paper_en.pdf>. Acesso em: 27.abr.2013.

${ }^{160}$ Comissão Europeia, Communication from the Commission to the European Parliament, the Council, the European Economic and Social Committee and the Committee of the Regions - Commission Work Programme, 2011, disponível em: <http://ec.europa.eu/atwork/pdf/cwp2012_annex_en.pdf>. Acesso em: 11.abr.2013.

${ }^{161}$ Comissão Europeia, Proposal for a Directive of the European Parliament and of the Council on Certain Rules Governing Actions for Damages under National Law for Infringements of the Competition Law Provisions of the Member States and of the European Union, disponível em: <http://eurlex.europa.eu/LexUriServ/LexUriServ.do?uri=COM:2013:0404:FIN:EN:PDF>. Acesso em: 21.set.2013.
} 
Parlamento Europeu ${ }^{162}$, tendo sido aprovado pelo Conselho de Ministros em 10 de novembro de 2014 e assinado em 26 de novembro de $2014^{163}$.

A Diretiva confirma alguns princípios que já haviam sido estabelecidos no Livro Branco, como o direito de qualquer prejudicado obter ampla reparação dos danos ("full compensation") por prejuízos decorrentes de infrações concorrenciais, incluindo danos emergentes e lucros cessantes (artigo $3^{\circ}$ ). Nesse particular, a Diretiva estabelece que a indenização deve fazer com que o lesado retorne à posição em que estaria caso a infração não tivesse ocorrido, prevendo expressamente que a indenização não deve resultar em compensação excessiva ("overcompensation"), seja por meio de "punitive damages" ou fatores multiplicadores da indenização.

Além disso, a Diretiva detalha e aprofunda outros temas que haviam sido discutidos no Livro Branco. As regras mais relevantes são as seguintes:

i) a Diretiva confirma que as decisões condenatórias proferidas pela Comissão Europeia e por autoridades nacionais de defesa da concorrência dos Estados Membros deverão ser vinculantes perante os tribunais dos Estados Membros com relação à existência da infração concorrencial (artigo $9^{\circ}$ );

ii) com o objetivo de facilitar a prova dos prejuízos, a Diretiva estabelece que, uma vez demonstrada a prática de cartel, há presunção relativa de que o cartel resultou em sobrepreço, a qual poderá ser afastada mediante provas apresentadas pelo réu (artigo 17, item 2) ${ }^{164}$; prevê-se ainda que, caso fique provado que o autor sofreu prejuízos, a quantificação poderá ser feita por meio de estimativas na hipótese de

\footnotetext{
${ }^{162}$ Parlamento Europeu, Amendments by the European Parliament to the Commission Proposal - Directive of the European Parliament and of the Council on Certain Rules Governing Actions for Damages under National Law for Infringements of the Competition Law Provisions of the Member States and of the European Union, disponível em: <http://www.europarl.europa.eu/sides/getDoc.do?pubRef=//EP//NONSGML+AMD+A7-2014-0089+002-002+DOC+PDF+V0//EN>. Acesso em: 30.out.2014.

163 Conforme ensina ANTONIO MANUEl DA ROCHA E MENEZES CORDEIRO, “quanto à aplicação ou, mais latamente, à jurisdicidade, importa sublinhar que as directrizes são comandos dirigidos, em primeira linha, aos Estados. Estes ficam obrigados a transpô-las, de acordo com o que delas resulte. Se os correspondentes diplomas de transposição não forem elaborados, os Estados poderão incorrer em responsabilidade perante as competentes instâncias comunitárias" (Direito Europeu das Sociedades, Coimbra, Almedina, 2005, p. 80).

164 A presunção é baseada em estudo encomendado pela Comissão Europeia, que concluiu, com base em estudo empírico, que, em cerca de $93 \%$ (noventa e três por cento) dos casos, os cartéis são bem sucedidos em aumentarem os preços em relação aos preços que vigorariam em um mercado competitivo (Oxera Consulting, Quantifying Antitrust Damages..., cit., p. 1).
} 
ser impossível ou excessivamente difícil precisar com exatidão o montante dos danos sofridos (artigo 17, item 1);

iii) a Diretiva confirma a admissibilidade da "pass-on defense" e prevê que o ônus da prova do repasse é do réu, que poderá solicitar a apresentação de provas que estejam em poder do autor ou terceiros (artigo 13); por outro lado, caso a demanda seja movida por um comprador indireto que alegue ter sofrido os efeitos do repasse, o ônus de provar o repasse nesse caso será do autor, que também poderá solicitar a apresentação de provas que estejam em poder do réu ou de terceiros (artigo 14); a Diretiva prevê que a Comissão Europeia irá editar documento contendo diretrizes ("guidelines") para o orientar os tribunais dos Estados Membros com relação à estimativa e quantificação do “pass-on” em cada caso concreto (artigo 16);

iv) com relação à prescrição, a Diretiva estabelece que as legislações dos Estados Membros deverão prever o seguinte: (a) o prazo de prescrição deverá ser de, no mínimo, cinco anos; (b) referido prazo não deverá começar a correr antes que o prejudicado possa razoavelmente ter ciência da infração concorrencial, dos danos causados e da identidade do infrator; e (c) o prazo deverá ser suspenso ou interrompido na pendência de investigação da prática por autoridade de defesa da concorrência (artigo 10);

v) a Diretiva procura facilitar a obtenção de provas pelos prejudicados, estabelecendo que, sempre que um autor apresentar evidências e indícios razoáveis de ter sofrido dano em virtude de prática anticompetitiva, os tribunais dos Estados Membros deverão determinar que os réus ou terceiros sejam obrigados, sob certas condições, a disponibilizar as evidências que possuam (artigo $5^{\circ}$ );

vi) a Diretiva prevê a possibilidade de solicitação de documentos e informações constantes dos autos de processos administrativos instaurados por autoridades concorrenciais, estabelecendo que os tribunais dos Estados Membros deverão avaliar a proporcionalidade do pedido com base em determinados critérios definidos na Diretiva (artigo $6^{\circ}$ ); com o objetivo de preservar os incentivos para a celebração de acordos de leniência e de transações com as autoridades concorrenciais, a Diretiva prevê que as confissões emitidas pelos réus no âmbito de 
acordos de leniência e de propostas de transação não deverão ser disponibilizadas como prova no âmbito de ações de indenização (artigo $6^{\circ}$, item 6); e

vii) a Diretiva estabelece que os membros do cartel são solidariamente responsáveis ("joint and several liability”), razão pela qual as vítimas podem cobrar a totalidade dos prejuízos de qualquer um dos infratores, mesmo daqueles de quem não adquiriram produtos ou serviços (artigo 11$)^{165}$; essa regra não é aplicável aos beneficiários de acordo de leniência, os quais, de modo semelhante ao que ocorre no direito norte-americano, somente serão responsáveis pelos danos que causaram aos adquirentes diretos e indiretos de seus próprios produtos ou serviços (ou seja, os beneficiários do acordo de leniência não serão responsáveis por pagar indenização referente aos produtos ou serviços vendidos pelos demais membros do cartel).

Após a publicação da Diretiva, os Estados Membros terão dois anos para adaptarem suas respectivas legislações de modo a refletir as disposições da Diretiva.

\subsection{Comparação entre os modelos norte-americano e europeu segundo os diferentes objetivos da prevenção de infrações e reparação de danos}

O exame crítico dos modelos norte-americano e europeu permite extrair algumas conclusões com relação à ênfase conferida por cada um dos sistemas aos dois objetivos da responsabilidade civil em matéria antitruste discutidos no início deste capítulo, a saber, reparação dos prejuízos e prevenção de infrações.

Embora ambos os objetivos sejam considerados importantes nos dois sistemas, pode-se afirmar que, de modo geral, o modelo norte-americano confere maior ênfase ao objetivo de prevenção que o modelo europeu ${ }^{166}$, que consagra a reparação dos

\footnotetext{
${ }^{165}$ Nos termos do art. 11, item 1, essa regra somente não se aplica aos membros do cartel que sejam pequenas e médias empresas, desde que tenham participação de mercado inferior a $5 \%$ (cinco por cento) durante o período do cartel e o pagamento da totalidade da indenização possa colocar em risco sua viabilidade econômica e causar prejuízos desvalorização de seus ativos. Nessa hipótese, tais membros somente responderão perante os adquirentes diretos e indiretos de seus produtos (i.e., tais membros não serão obrigados a pagar indenização em favor de clientes das outras empresas do cartel).

${ }^{166}$ RICHARD A. POSNER, escrevendo sobre os objetivos das sanções no direito antitruste norte-americano, defende que a compensação das vítimas deve ser encarada como um objetivo subsidiário, pois um sistema
} 
danos como principal objetivo da responsabilidade civil antitruste ${ }^{167}$. Algumas das diferenças entre os modelos norte-americano e europeu de reparação de danos permitem ilustrar essa diferença de enfoques.

O primeiro exemplo é o montante da indenização. No direito norteamericano, como visto, os prejudicados possuem o direito de receber pagamento em valor equivalente ao triplo dos prejuízos sofridos em decorrência da infração concorrencial, regra que costuma ser justificada por assegurar maior eficácia na prevenção de condutas anticompetitivas $^{168}$. No modelo europeu, que enfatiza a reparação dos danos efetivamente sofridos, a indenização se mede pela extensão dos prejuízos.

Outro exemplo que muito bem ilustra as diferenças de ênfase entre reparação e prevenção nos modelos norte-americano e europeu são as regras referentes à admissibilidade da "pass-on defense" e à legitimidade dos compradores indiretos.

Como visto, o direito federal norte-americano não admite a "pass-on defense" e permite que os compradores diretos recebam a totalidade da indenização mesmo que tenham repassado o sobrepreço para o elo seguinte da cadeia. Além disso, os compradores indiretos não possuem legitimidade para pleitear indenização, mesmo que

adequado de prevenção teria como resultado a diminuição do nível de danos causados pelas práticas anticompetitivas. Nas palavras do autor: "The basic objective of a remedial system is to deter people from violating the law. Another is to compensate the victims of the violators, but I regard this as subsidiary because a well-designed system of deterrence would reduce the incidence of antitrust violations to a low level and because, as we shall see, such a system would, as by-product, assure adequate compensation except in those instances where the costs of administering compensation were prohibitive" (Antitrust Law: An Economic Perspective, Chicago, University of Chicago Press, 1976, p. 221).

167 “A (...) policy principle behind damages actions, and one that is embedded in EU law, is that of compensation. As stated in the European Commission's 'White Paper on Damages Actions for Breach of the EC Antitrust Rules' and its accompanying Commission staff working paper, published in April 2008: 'Any citizen or business who suffered harm as a result of a breach of EC antitrust rules (Articles 81 and 82 of the EC Treaty [now Articles 101 and 102 TFEU]) must be able to claim reparation from the party who caused the damage. This right of victims to compensation is guaranteed by Community law, as the European Court of Justice recalled in 2001 and 2006. Victims of an EC competition law infringement are entitled to full compensation of the harm caused. That means compensation for actual loss (damnum emergens) and for loss of profit (lucrum cessans), plus interest from the time the damage occurred until the capital sum awarded is actually paid."' (GUNNAR NIELS, HELEN JENKINS e JAMES KAVANAGH, Economics for Competition Lawyers, cit., pp. 495-496).

${ }^{168}$ HeRBERT HOVEMKAMP escreve: "The rationale given for treble damages in private antitrust actions are manifold. Perhaps the oldest is that the antitrust violator deserves to be punished for his crimes, and mere payment of single damages is not punishment enough. This moral argument has gradually given way to an argument based on general deterrence: since not all antitrust violations are detected, a rule providing only single damages would make antitrust violations profitable" (Federal Antitrust Policy..., cit., p. 654). 
tenham sofrido parcela ou até mesmo a totalidade do sobrepreço. Entende-se que essa solução é a que melhor assegura a prevenção de práticas anticompetitivas, não obstante em certos casos possa ser conflitante com o objetivo de reparação dos danos, por deixar parcela dos prejudicados sem indenização ${ }^{169}$.

No sistema europeu, diferentemente, a Diretiva da União Europeia sobre o assunto confirma a admissibilidade da "pass-on defense" e assegura a legitimidade dos compradores indiretos, como forma de assegurar o objetivo da reparação dos danos ${ }^{170}$.

A discussão sobre a legitimidade dos compradores indiretos demonstra que, embora os objetivos da reparação e prevenção sejam, de modo geral, complementares - ou seja, a perspectiva de ter de reparar os danos também serve de desestímulo aos potenciais infratores - podem existir situações em que os objetivos sejam conflitantes ${ }^{171}$. HERBERT HOVEMKAMP esclarece a questão ${ }^{172}$ :

\footnotetext{
${ }^{169}$ RICHARD A. POSNER descreve as vantagens da regra sob o ponto de vista da prevenção de práticas anticompetitivas: "Suppose a monopoly of shoes sells to 10 distributors who in turn resell to 1000 resalers who in turn resell to 1 million consumers. It makes sense to permit the 10 distributors to sue the monopolist for the entire monopoly overcharge, even though they will in all likelihood have passed on the bulk of the overcharge to the retailers who in turn will have passed it on to the consumers. Depending on the degree of passing on, the distributors' suit may yield them windfall gains, yet the most important thing from an economic standpoint - deterring monopoly - will have been accomplished more effectively than if such suits are barred" (Economic Analysis of Law, $5^{\text {th }}$ ed., New York, Aspen, 1998, p. 344).

${ }^{170}$ WOUTER P. WILS confirma as diferenças entre o direito norte-americano e o direito europeu no tocante às ações indenizatórias em matéria concorrencial. Com relação ao direito europeu, o autor observa que "the 2008 White Paper states that its 'primary objective [...] is to improve the legal conditions for victims to exercise their right under the Treaty to reparation of all damage suffered as a result of a breach of the EC antitrust rules. Full compensation is, therefore, the first and foremost guiding principle". No tocante ao direito norte-americano, o autor esclarece que "the deterrence approach is the one taken by US federal antitrust law, as shown in particular by the provision of treble damages, the exclusion of passing-on defence in actions brought by direct purchasers and the denial of standing to indirect purchasers" ("The Relationship Between Public Antitrust Enforcement and Private Actions for Damages", in World Competition, v. 32, n. 1, 2009, disponível em: <http://papers.ssrn.com/sol3/papers.cfm?abstract_id=1296458>. Acesso em: 30.nov.2014, pp. 15-17).

${ }^{171}$ GIORGIO MONTI observa que esse exemplo ilustra a existência de três objetivos perseguidos pelo sistema de responsabilidade civil antitruste, os quais podem ser conflitantes entre si, a saber: reparação dos danos sofridos pelas vítimas, prevenção de práticas anticompetitivas e facilidade de operação do sistema de reparação. Nas palavras do autor: "The debate about whether indirect purchasers should be entitled to sue shows that there are three conflicting attributes that we seek in a damages regime: that it compensate fully, that it deters adequately and that it is simple to operate. Ease of operation is inconsistent with full compensation, and adequate deterrence is hard to achieve unless all harms caused by the anticompetitive behavior are caught" (EC Competition Law, cit., p. 433).
}

${ }^{172}$ Federal Antitrust Policy..., cit., p. 621. 
“(...) attitudes toward the indirect purchaser rule track ideology closely. Those who believe that antitrust enforcement should be concerned exclusively with efficiency generally support Illinois Brick. Those who believe that antitrust should be concerned with full compensation to victims generally disapprove. Both positions are ideologically consistent. Permitting indirect purchaser actions would increase the costs of litigation and may result in overdeterrence. However, the Illinois Brick rule clearly deprives injured parties of the claim to damages.".

Note-se que, mesmo no sistema europeu, o objetivo de reparação dos danos não é absoluto e, em determinadas situações, cede espaço aos objetivos da política de prevenção de infrações concorrenciais. É o que ocorre com relação ao acesso às declarações e confissões emitidas por beneficiários dos acordos de leniência no âmbito de investigações concorrenciais. Embora o acesso a tais informações possa facilitar a obtenção de indenização pelos prejudicados, a Diretiva aprovada na União Europeia assegura a confidencialidade de tais documentos, como forma de preservar os incentivos ao programa de leniência e, em última análise, atender ao objetivo de prevenção de infrações.

O capítulo seguinte analisará a disciplina da responsabilidade civil por danos decorrentes da prática de cartel no direito brasileiro, o que permitirá, ao final do trabalho, que seja feita uma avaliação sobre a ênfase conferida no direito brasileiro aos dois objetivos discutidos no capítulo 3, a saber, reparação dos danos e prevenção de infrações. 


\section{RESPONSABILIDADE CIVIL POR DANOS DECORRENTES DA PRÁTICA DE CARTEL NO DIREITO BRASILEIRO}

Concluído o exame da matéria no direito estrangeiro, este capítulo analisará em detalhes os elementos da responsabilidade civil por danos decorrentes da prática de cartel no direito brasileiro.

\subsection{Responsabilidade civil por danos decorrentes da prática de cartel no direito brasileiro: considerações gerais}

\subsubsection{A responsabilidade civil no Código Civil e o art. 47 da Lei 12.529/2011}

A regra geral de responsabilidade civil no ordenamento jurídico brasileiro está prevista no artigo 927 do Código Civil, o qual prevê que "aquele que, por ato ilícito (arts. 186 e 187), causar dano a outrem fica obrigado a repará-lo".

Complementando e reforçando a regra geral acima transcrita, o art. 47 da Lei 12.529/2011 dispõe expressamente que os prejudicados pela prática de infrações à ordem econômica poderão ingressar em juízo contra os infratores para obter indenização por perdas e danos. Veja-se o inteiro teor do dispositivo em questão:

“Art. 47. Os prejudicados, por si ou pelos legitimados do art. 82 da Lei $n^{\circ}$ 8.078, de 11 de setembro de 1990, poderão ingressar em juízo para, em defesa de seus interesses individuais ou individuais homogêneos, obter a cessação de práticas que constituam infração da ordem econômica, bem como o recebimento de indenização por perdas e danos sofridos, independentemente do inquérito ou processo administrativo, que não será suspenso em virtude do ajuizamento de ação".

Embora a reparação dos danos em tese já estivesse assegurada pelo regime geral do Código Civil, a positivação de norma expressa na Lei 12.529/2011 prevendo o direito à indenização por perdas e danos decorrentes de infração à ordem econômica não deve ser interpretada como simples repetição da regra do Código Civil. 
Nesse sentido, TÉrcio SAMPAIO FERRAZ JÚNIOR, ao comentar o dispositivo em questão, sustenta ${ }^{173}$ :

"Ou seja, como a hipótese de reparação de dano, tanto no Código Civil de 1916 quanto no de 2002, era prevista, nem haveria necessidade de nova previsão nem mesmo para "declarar" que a reparação deveria ocorrer nos estritos termos daqueles Códigos (numa forma de remissão implícita). Afinal, se o legislador nunca é redundante nem prescreve superfluamente, isto é, se cada norma, ainda que aparentemente esteja a regulamentar a mesma facti species, tem destinação própria e específica, e, ao sancionar uma norma, o legislador é sempre finalista, sempre tem algum objetivo próprio e específico (não há palavras nem normas inúteis), então a referida disposição da lei antitruste não deve ser reduzida, pura e simplesmente, à prescrição de reparação de dano já existente no Código Civil, mas há de referir-se a um estatuto jurídico próprio".

Desse modo, o art. 47 da Lei 12.529/2011 viabiliza a aplicação dos princípios da lei concorrencial $^{174}$ no âmbito da responsabilidade civil por cartel e outras práticas anticompetitivas, o que ficará evidente a partir da análise empreendida nos itens abaixo.

Por fim, registre-se que, embora a lei concorrencial brasileira estabeleça que “a coletividade é a titular dos bens jurídicos protegidos por esta lei” (art. 1º parágrafo único) ${ }^{175}$, entendendo-se que o objeto precípuo de proteção do direito concorrencial seja a própria concorrência, encarada, segundo CALIXTO SALOMÃo FILHO, como instituição ${ }^{176}$ e não os concorrentes, consumidores ou demais prejudicados diretamente -, tal

\footnotetext{
173 "Direito da Concorrência e Enforcement Privado na Legislação Brasileira", cit., p. 21.

174 TÉrCIO SAMPAIO FERRAZ JÚNIOR esclarece: “A lei de defesa da concorrência, nesse sentido, guarda analogia com a lei de defesa do consumidor (ambas lidam com interesses difusos e ambas preveem também a reparação do dano individual). Nesse sentido, como esta última, a lei concorrencial é uma lei principiológica, no sentido de que nem é lex generalis nem lex specialis. Sua natureza constitucional (art. 174, $\S 4^{\circ} \mathrm{c} / \mathrm{c}$ art. 170, caput e IV da CF) faz dela a legislação que estabelece os fundamentos sobre os quais se erigem as relações concorrenciais - concorrentes em concorrência e concorrência entre concorrentes - em que esteja presente alguma forma de poder econômico. Por isso as leis concorrenciais setorizadas na legislação de direito regulatório não obedecem, quanto às questões de concorrência, a princípios próprios, mas estão sujeitas aos princípios fundamentais da lei de defesa da concorrência" ("Direito da Concorrência e Enforcement Privado na Legislação Brasileira", cit., p. 19).

175 José MARCElo Martins ProençA, comentando dispositivo idêntico da lei concorrencial anterior, esclarece que fica "evidenciado, portanto, expressamente, pela Lei n. 8.884/94, que o mercado é um bem coletivo, ou seja, todas as pessoas são titulares do seu direito de proteção, tratando-se de um direito difuso, dada a sua transindividualidade, de natureza indivisível, sendo titulares pessoas indeterminadas e ligadas por circunstâncias de fato, sem relação jurídica-base no aspecto subjetivo" (Concentração Empresarial..., cit., p. 50).

${ }^{176}$ CaliXto Salomão Filho, Direito Concorrencial - As Condutas, cit., pp. 75-81.
} 
entendimento não afasta a reparação dos danos sofridos pelos prejudicados como resultado de práticas lesivas à concorrência, a qual é assegurada pelo art. 47 da Lei 12.529/2011.

Como novamente esclarece TÉrCIO SAMPAIO FERRAZ JÚNIOR, a responsabilidade civil em matéria concorrencial tem por objeto o ressarcimento "de prejuízos cujo núcleo causal está não na propriedade (em sentido privatista de conduta individual e individualizável), mas na competição (em sentido de interesse difuso: seus interesses individuais ou individuais homogêneos), mas individualizados no agente econômico que os sofre" ${ }^{\text {177. }}$.

Desse modo, embora as infrações à ordem econômica (como os cartéis) sejam práticas que tenham por objeto ou possam resultar em efeitos adversos para a concorrência, tais condutas também podem, nos termos do artigo 47 da Lei 12.529/2011, violar os “interesses individuais e individuais homogêneos"178 dos prejudicados, autorizando a propositura de ação indenizatória para ressarcimento dos prejuízos.

\subsubsection{Legitimidade ativa e passiva}

Antes de passar ao estudo dos pressupostos da responsabilidade civil por danos decorrentes da prática de cartel, deve-se examinar brevemente a questão da legitimidade ativa e passiva com relação às ações indenizatórias.

O artigo 47 da Lei 12.529/2011 prevê que têm legitimidade para pleitear indenização os "prejudicados", seja diretamente ou indiretamente por meio da legitimação extraordinária prevista no artigo 82 da Lei no 8.078, de 11 de setembro de 1990 (“Código de Defesa do Consumidor").

177 “Direito da Concorrência e Enforcement Privado na Legislação Brasileira”, cit., p. 22.

${ }^{178} \mathrm{O}$ conceito de interesses individuais homogêneos consta do art. 81 do Código de Defesa do Consumidor, que estabelece os conceitos de interesses difusos, coletivos e individuais homogêneos: "Art. 81. A defesa dos interesses e direitos dos consumidores e das vítimas poderá ser exercida em juízo individualmente, ou a título coletivo. Parágrafo único. A defesa coletiva será exercida quando se tratar de: I - interesses ou direitos difusos, assim entendidos, para efeitos deste código, os transindividuais, de natureza indivisível, de que sejam titulares pessoas indeterminadas e ligadas por circunstâncias de fato; II - interesses ou direitos coletivos, assim entendidos, para efeitos deste código, os transindividuais, de natureza indivisível de que seja titular grupo, categoria ou classe de pessoas ligadas entre si ou com a parte contrária por uma relação jurídica base; III - interesses ou direitos individuais homogêneos, assim entendidos os decorrentes de origem comum". 
No caso da prática de cartel, os prejudicados a que faz menção o artigo 47 serão todos aqueles que tenham sofrido os efeitos do sobrepreço do cartel, seja por terem adquirido diretamente os produtos do cartel, seja porque sofreram os efeitos do repasse do sobrepreço em razão de um cartel realizado em elo anterior da cadeia produtiva. Nesse sentido, os prejudicados aludidos pelo artigo 47 incluem:

i) empresas que tenham adquirido insumos a preços artificialmente elevados em decorrência do cartel ${ }^{179}$;

ii) consumidores ${ }^{180}$ que tenham adquirido bens ou serviços com sobrepreço ${ }^{181}$; e

iii) entes federados (União, Estados, Municípios e Distrito Federal) e entidades da administração indireta que tenham sido lesados em razão da combinação de lances e/ou participantes em licitações públicas ${ }^{182}$.

Registre-se que, dada a abrangência do artigo 47 da Lei 12.529/2011 - que confere legitimidade aos "prejudicados", sem fazer distinção entre compradores diretos e indiretos - não se justifica no direito brasileiro eventual interpretação no sentido de negar legitimidade aos compradores indiretos, tal como ocorre no direito federal norteamericano, conforme estudado no capítulo 4. Desse modo, a exemplo do que ocorre no direito comunitário europeu, os compradores indiretos também possuem legitimidade para pleitear ressarcimento pelos prejuízos eventualmente sofridos, mesmo que não tenham adquirido os produtos ou serviços diretamente do cartel e tenham apenas sofrido os efeitos

\footnotetext{
${ }^{179}$ No caso do chamado cartel de compra, os prejudicados serão aqueles que tenham vendido (e não adquirido) produtos ao cartel, e o dano não será resultante do sobrepreço, mas sim do preço artificialmente reduzido em virtude da combinação entre os compradores.

${ }^{180}$ De acordo com o artigo $2^{\circ}$, caput, do Código de Defesa do Consumidor, "consumidor é toda pessoa física ou jurídica que adquire ou utiliza produto ou serviço como destinatário final".

181 "Nesse caso, os prejudicados de que trata o artigo podem ser as empresas prejudicadas em sua atividade econômica pelas infrações ou até mesmo os próprios consumidores, que se sintam lesados pelos efeitos das infrações à ordem econômica" (EDUARDO CAMINATI ANDERS, LEOPOLDO PAGOTTO e VICENTE BAGNOLI, Comentários à Nova Lei de Defesa da Concorrência: Lei n. 12.529, de 30 de novembro de 2011, Rio de Janeiro, Forense, 2012, p. 189).

${ }^{182}$ Como esclarece Roberto Augusto CASTELlanos PFeIFFer, "os entes federados podem propor ação em nome próprio, caso comprovem que o seu patrimônio foi lesado por determinada conduta anticompetitiva" (Defesa da Concorrência e Bem-Estar do Consumidor, cit., p. 255).
} 
do repasse do sobrepreço ${ }^{183}$. A questão do repasse será analisada em detalhes nos tópicos adiante.

Conforme dicção expressa do artigo 47 da Lei 12.529/2011, o ressarcimento pelos danos decorrentes de infração à ordem econômica pode ser pleiteado pelos prejudicados individualmente ou, em sede de tutela coletiva, por intermédio da legitimação extraordinária prevista no art. 82 do Código de Defesa do Consumidor ${ }^{184}$.

Além disso, a Lei no 7.347, de 24 de julho de 1985 (“Lei de Ação Civil Pública"), também confere legitimidade aos entes ali especificados para a propositura de “ações de responsabilidade por danos morais e patrimoniais causados" (...) "por infração da ordem econômica" (art. 1 ${ }^{\circ}$, inc. V) ${ }^{185}$.

${ }^{183}$ De acordo com LuIz CARLOS Buchain: “Assim, na hipótese de abuso de preços contra o agente econômico que primeiramente pagou a mercadoria, a transferência do preço para o mercado através da cadeia econômica não retira sua legitimidade (do primeiro adquirente) para defesa de seu direito individual ou individual homogêneo. Os demais integrantes da cadeia econômica que sofrem o dano originalmente cometido por um agente remoto na cadeia econômica também possuem legitimidade ativa contra aquele, mas não contra os demais intermediários que também foram vítimas da mesma prática infracional da concorrência" (O Poder Econômico e a Responsabilidade Civil Concorrencial, Porto Alegre, Nova Prova Editora, 2006, p. 147).

${ }^{184}$ Sobre a legitimidade para propositura da ação, JOÃO BOSCO LEOPOLDINO DA FONSECA escreve o seguinte: “Os prejudicados poderão, por si próprios, ingressar em juízo. A lei concede à pessoa que é titular do direito subjetivo material que foi lesado o direito de ajuizar ela própria a ação. (...) Em se tratando de uma coletividade, que tenha sofrido lesão em seus interesses, poderá ela assumir a defesa dos seus interesses individuais homogêneos, e neste caso deverá estar representada pelos legitimados do artigo 82 da Lei $\mathrm{n}^{\circ}$ 8.078, de 1990" (Lei de Proteção da Concorrência - Comentários à Legislação Antitruste, $3^{\mathrm{a}}$ ed., Rio de Janeiro, Forense, 2007, p. 289).

185 PAUlo FeliPe CARNeIRo DE Freitas observa que "apesar de a dicção literal do art. 47 da Lei $n^{\circ}$ 12.529/2011 dizer respeito apenas ao dano individual homogêneo, é possível antever, numa interpretação sistemática do ordenamento jurídico, a possibilidade de ajuizamento de tutela coletiva referente a danos difusos e coletivos, se evidenciados no caso concreto. No que se refere a danos difusos, há a possibilidade de utilização da tutela coletiva como expressamente previsto no art. $1^{\circ}$, incisos IV e V da Lei 7.347/1985 que dispõe que é possível ajuizar coletivamente ação de responsabilidade por danos morais e patrimoniais 'por infração da ordem econômica e da economia popular' ou referente 'a qualquer outro interesse difuso ou coletivo. Por sua vez, quanto aos interesses coletivos stricto sensu, tem-se como substrato normativo o artigo 81, inciso II do CDC, aplicável às demandas da concorrência por força do artigo 115 da Lei no 12.529/2011', (Tutela Coletiva da Responsabilidade Civil por Infração da Ordem Econômica, Dissertação de Mestrado, Faculdade de Direito da Universidade de São Paulo, 2013, p. 12). Em sentido semelhante, PRISCILA BRÓLIO GONÇALVES: “A ação de que trata o art. 29 da Lei $n^{\circ}$ 8.884/94 destina-se apenas à tutela dos direitos individuais e individuais homogêneos, muito embora existam outros mecanismos de tutela dos interesses difusos e coletivos violados pela adoção de práticas contrárias à ordem econômica - o próprio processo administrativo disciplinado no art. 32 e seguintes da Lei $n^{\circ}$ 8.884/94 é um deles, e não devemos nos esquecer da ação civil pública, disciplinada no art. $1^{\circ}$, inciso V, da Lei n ${ }^{\circ} 7.347 / 85$ " (Direito Concorrencial: Aspectos Jurídicos e Econômicos - Comentários à Lei 8.884/94 e Estudos Doutrinários, Rio de Janeiro, América Jurídica, 2002, p. 259). 
Da conjugação dos dispositivos legais acima mencionados, conclui-se que os entes legitimados para a propositura da ação coletiva de responsabilidade civil por danos oriundos da prática de cartel são os seguintes:

o Ministério Público, devendo ser destacado que, em sua maioria, os poucos precedentes existentes até o momento no Brasil em que houve decisão condenando a reparar os danos causados por cartéis foram proferidos em ações coletivas ajuizadas pelo Ministério Público ${ }^{186-187}$;

ii) a União, os Estados, o Distrito Federal e os Municípios, que, nesse caso, atuam como substitutos processuais dos administrados ${ }^{188-189}$, não devendo a ação coletiva

\begin{abstract}
${ }^{186}$ A pesquisa jurisprudencial realizada neste trabalho identificou a existência de alguns precedentes em sede de tutela coletiva em que houve decisão condenando ao ressarcimento de danos materiais e/ou morais causados pela prática de cartel, quais sejam: revenda de combustíveis em Guaporé-RS (TJ/RS, Apelação Cível no 70018714857, $3^{\mathrm{a}}$ Câmara Cível, Rel. Paulo de Tarso Vieira Sanseverino, j. 12.07.2007); revenda de combustíveis em José Bonifácio-SP (TJ/SP, Apelação Cível nº 994.03.009153-6, 11 a Câmara de Direito Público, Rel. Des. Luiz Ganzerla, j. 08.02.2010); revenda de combustíveis em Jaboticabal-SP (Ação Civil Pública no 291.01.2006.000904-1, Juíza de Direito Carmen Silva Alves, Comarca de Jaboticabal - SP, j. 20.05.2008); distribuição de GLP na região metropolitana de Porto Alegre-RS (Ação Civil Pública $\mathrm{n}^{\circ}$ 97.00.21424-9-RS, Juíza Federal Paula Beck Bohn, Subseção de Porto Alegre - RS, j. 13.01.2010); revenda de combustíveis em Santa Maria-RS (Ação Civil Pública $\mathrm{n}^{\circ}$ 027/1.05.0004158-2, Juíza de Direito Stefânia Frighetto Schneider, 14a Vara Cível de Santa Maria-RS, j. 28.12.2010); e revenda de combustíveis em Pernambuco (Tribunal Regional Federal da $5^{\text {a }}$ Região, Apelação $\mathrm{n}^{\circ} 498545$ - origem $\mathrm{n}^{\circ}$ 001233456.1999.4.05.8300, $3^{\mathrm{a}}$ Turma, Relator Des. Federal Luiz Alberto Gurgel de Faria, j. 22.11.2012).
\end{abstract}

187 Note-se ainda que a Defensoria Pública, que passou a ser incluída no rol dos legitimados para a propositura de ação civil pública a partir da Lei no 11.448 , de 15 de janeiro de 2007. Registre-se que está em trâmite no Supremo Tribunal Federal ação direta de inconstitucionalidade ajuizada pela Associação Nacional dos Membros do Ministério Público - CONAMP (ADI 3934), que sustenta a inconstitucionalidade do dispositivo em questão por alegar, dentre outros fundamentos, que a competência da Defensoria Pública para a propositura de ações civis públicas pode afetar as atribuições do Ministério Público.

${ }^{188}$ Nesse sentido, Roberto Augusto Castellanos PfeifFer sustenta que "os entes federados também podem propor ação coletiva para reparação de direitos individuais homogêneos de seus administrados, no âmbito da legitimação extraordinária estabelecida pelo artigo 29 da Lei no 8.884/94 e art. 82, II do Código de Defesa do Consumidor" (Defesa da Concorrência e Bem-Estar do Consumidor, cit., p. 255).

189 Sobre a legitimação extraordinária dos entes federados, PRISCILA BRÓLIO GONÇALVES observa que "em princípio, não há interesse da União, por exemplo, em defender individuais afetados pela prática de uma infração à ordem econômica que só teve efeitos em uma determinada região ou localidade do país, até porque as autoridades federais de defesa da concorrência já atuam no exercício do poder de polícia. Que os Estados ou Municípios atingidos, ou ainda as associações locais, tomem essas iniciativas. Da mesma forma, aos Estados e Municípios, assim como às associações civis de âmbito estadual ou municipal, não há que ser reconhecido o interesse de agir na defesa de direitos individuais violados por condutas anticompetitivas ocorridas em outras localidades distantes. (...) É evidente que um hipotético cartel entre os grandes produtores nacionais de aço tem o condão de prejudicar a economia nacional como um todo, sendo compreensível que a União e outras entidades federais públicas e privadas queiram intervir para tutelar os interesses individuais dos prejudicados, pois estes encontrar-se-ão espalhados por todo o território nacional. O mesmo não se pode dizer de um eventual acordo para fixar preços entre os supermercados de um determinado Município. Embora as consequências possam ser nefastas para os consumidores daquela localidade, (...) seria questionável o interesse da União nessa demanda" (Direito Concorrencial: Aspectos Jurídicos e Econômicos..., cit., pp. 259-260). 
ser confundida com a ação ajuizada em nome próprio pelos entes federados caso sofram prejuízos decorrentes de cartel em licitação, conforme acima mencionado; institucionais a defesa dos consumidores ou da ordem econômica ${ }^{190}$; e

iv) entidades da administração pública indireta (autarquias, empresas públicas, fundação ou sociedades de economia mista), desde que incluam entre seus fins institucionais a defesa dos consumidores, nos termos do art. 82, inc. III do Código de Defesa do Consumidor ${ }^{191}$.

É de se questionar se o CADE, na qualidade de autarquia federal, teria legitimidade para a propositura de ação coletiva para cobrança de danos causados por práticas anticompetitivas. A resposta ao questionamento deve ser negativa, uma vez que a eventual atuação do CADE na qualidade de autor de ações indenizatórias poderia

190 De acordo com CAliXto SALOMÃo Filho, “(...) toda vez que for possível demonstrar que do ato anticoncorrencial decorreu prejuízo a um grupo identificável de consumidores, será possível a qualquer associação de defesa dos consumidores promover a demanda (art. 82, IV, c/c o art. 91, do CDC". (Direito Concorrencial - As Condutas, cit., p. 85). No mesmo sentido, ROBERTO AUgusto CASTELlanOS PFEIFFER escreve que "dada a expressa menção do art. 29 e a íntima relação entre a defesa do concorrência e a proteção do consumidor, entendo que há amparo para legitimação das associações para a propositura de ação coletiva para reparação de danos causados por infração contra a ordem econômica" (Defesa da Concorrência e BemEstar do Consumidor, cit., p. 256).

${ }^{191}$ Com relação à legitimidade de órgãos da administração pública indireta, deve-se mencionar a existência de precedente no qual foi indeferida liminarmente a inicial de ação civil pública ajuizada pela Companhia de Saneamento Básico do Estado de São Paulo ("Sabesp") contra as empresas do mercado de gases industriais na esteira de decisão do CADE que concluiu pela existência de cartel no mercado. A sentença entendeu que a Sabesp seria parte ilegítima para propositura da ação civil pública, nos seguintes termos: "O caso vertente (...) não pode ser considerado como difuso ou coletivo, porque veicula pretensão de índole puramente individual, já que a autora pretende seu ressarcimento por eventuais danos materiais e morais pela comercialização de gases industriais em regime de cartel e, ainda que esse direito subjetivo caiba a outros 'interessados e legitimados', o pleito não extrapola a esfera privativa de seus titulares imediatos. De qualquer sorte, a legitimidade para promover ação civil pública objetivando a defesa de direitos individuais homogêneos e disponíveis ocorre em hipóteses restritas, quando houver interesses público e social relevantes ou, no caso da lei atribuir tal legitimidade, o que não é o caso dos autos. Por outro lado, ainda que se atribua à pretensão conotação de direito coletivo ou difuso, imperioso destacar que a parte autora não demonstrou, objetivamente, a relação de pertinência entre sua finalidade institucional e o pedido veiculado na demanda. A interpretação literal dos artigos $5^{\circ}$, da Lei 7.347/85 e artigo 82, IV, do Código de Defesa do Consumidor permitiria concluir que só às associações civis exige-se o requisito da pertinência temática, entretanto, onde há a mesma razão deve-se aplicar a mesma disposição, pois as entidades da administração pública também têm seus fins peculiares, os quais, nem sempre, se coadunam com a defesa de interesses difusos e coletivos. E esse é o caso dos autos, pois a autarquia é expressão da descentralização administrativa, de modo que desenvolve capacidade específica para a prestação de determinado serviço ou desempenho de função, como a autora que foi criada para 'planejar, executar e operar os serviços públicos de saneamento básico'. Não ficou demonstrado, portanto, o legítimo interesse jurídico na causa, já que sua finalidade institucional não corresponde à legitimidade" (Acão Civil Pública 0000233-25.2011.403.6100, 28 $8^{\mathrm{a}}$ Vara Federal da Subseção Judiciária de São Paulo). 
prejudicar a imparcialidade da autarquia em suas funções de órgão judicante em matéria concorrencial $^{192}$.

De resto, o art. 118 da Lei 12.529/2011 ${ }^{193}$ já define o papel do CADE nas ações judiciais que discutam a aplicação da lei concorrencial, prevendo que o CADE deverá ser intimado para, querendo, intervir no feito na qualidade de assistente. Em casos envolvendo pleitos indenizatórios por cartel, o CADE usualmente manifesta interesse em atuar somente em demandas envolvendo infrações a respeito das quais já tenha havido manifestação definitiva no âmbito do respectivo processo administrativo ${ }^{194}$.

A existência de mecanismos adequados de tutela coletiva é considerada como fator importante para o desenvolvimento de ações indenizatórias em matéria concorrencial, tendo sido apontada pela Comissão Europeia como uma das prioridades de sua atuação na área, conforme estudado no capítulo 4.

O estudo aprofundado das questões processuais relativas à tutela coletiva em matéria de responsabilidade civil concorrencial escapa ao objeto deste trabalho ${ }^{195}$, que se concentra nos problemas de direito material. Exceto quando expressamente mencionado, as considerações sobre o direito material feitas neste trabalho se aplicam indistintamente à tutela individual e à tutela coletiva da responsabilidade civil por danos decorrentes de cartel.

Com relação à legitimidade passiva, o artigo 31 da Lei no 12.529 estabelece que "esta Lei se aplica às pessoas físicas ou jurídicas de direito público ou privado, bem como a quaisquer associações de entidades ou pessoas, constituídas de fato ou de direito,

\footnotetext{
${ }^{192}$ No sentido da ilegitimidade ativa do CADE para propositura de ações de indenização, vide: ROBERTO Augusto Castellanos Pfeiffer, Defesa da Concorrência e Bem-Estar do Consumidor, cit., pp. 258-259.

193 “Art. 118. Nos processos judiciais em que se discuta a aplicação desta Lei, o Cade deverá ser intimado para, querendo, intervir no feito na qualidade de assistente".

194 Como exemplo, pode-se citar o processo envolvendo pedido de indenização pela prática de cartel no mercado de vergalhões de aço (Processo no 2009.38.00.015651-4, 17 ${ }^{\text {a }}$ Vara Federal da Seção Judiciária de Minas Gerais - Belo Horizonte). Em sua manifestação, o CADE afirmou que "em razão da deliberação do Plenário do CADE nos autos do Processo Administrativo no 08012.004086/2000-21, que constatou a prática de conduta infracional pelas requeridas (cópia da decisão anexa), verifica-se o interesse jurídico de intervir no presente feito".

${ }^{195}$ Sobre o tema da tutela coletiva da responsabilidade civil em matéria concorrencial, vide: PAULO FELIPE CARNEIRO DE FreITAS, Tutela Coletiva da Responsabilidade Civil por Infração da Ordem Econômica, cit., pp. 71-87).
} 
ainda que temporariamente, com ou sem personalidade jurídica, mesmo que exerçam atividade sob regime de monopólio legal”. Nesse sentido, quaisquer das pessoas e entidades acima enumeradas, desde que, naturalmente, tenham tido participação ou contribuído para a prática de cartel, poderão figurar no polo passivo da ação de responsabilidade civil ${ }^{196}$.

\subsection{Pressupostos da responsabilidade civil por danos decorrentes da prática de cartel}

O artigo 186 do Código Civil dispõe que "aquele que, por ação ou omissão voluntária, negligência ou imprudência, violar direito e causar dano a outrem, comete ato ilícito". Como adiantado, o artigo 927 do Código Civil, por sua vez, prevê que "aquele que, por ato ilícito (arts. 186 e 187), causar dano a outrem, fica obrigado a repará-lo".

O exame dos dispositivos em questão permite identificar os quatro elementos essenciais para caracterização da responsabilidade civil no direito brasileiro, quais sejam (i) a prática de um ato ilícito por ação ou omissão; (ii) a culpa do agente (em sentido amplo, incluindo tanto a ação negligente e imprudente como o dolo); (iii) o dano causado a outrem; e (iv) a existência de nexo de causalidade entre a conduta e o resultado danoso $^{197}$.

\footnotetext{
${ }^{196}$ Comentando dispositivo idêntico da lei concorrencial, veja-se o entendimento de PRISCILA BRólIO GONÇALVES: "Em primeiro lugar, importa observar quem pode ser réu na ação prevista no art. 29 da Lei ${ }^{\circ}$ 8.884/94. É evidente que a ação deve ser proposta em face daqueles a quem se imputa a prática de infrações contra a ordem econômica que, em tese, atingiram os interesses individuais cuja tutela jurisdicional é pleiteada. O art. 15 da Lei n. 8.884/94 deixa claro que quaisquer pessoas físicas ou jurídicas, de direito público ou privado, bem como quaisquer associações ou entidades sem personalidade jurídica, mesmo que exerçam atividade sob regime de monopólio legal, podem infringir a ordem econômica. Consequentemente, todas essas pessoas podem figurar no polo passivo da ação prevista no art. 29, desde que lhes sejam atribuídas, ainda que em tese, práticas vedadas pela legislação" (Direito Concorrencial: Aspectos Jurídicos e Econômicos..., cit., p. 255).

${ }^{197}$ Na lição de CARLOS ROBERTO GONÇALVES: "A análise do artigo supratranscrito evidencia que quatro são os elementos essenciais da responsabilidade civil: ação ou omissão, culpa ou dolo do agente, relação de causalidade e o dano experimentado pela vítima" (Responsabilidade Civil, 13ª ed., São Paulo, Saraiva, 2011, p. 65). No mesmo sentido, a lição de SILVIO SALVo Venosa: "Decantados esses dispositivos, verifica-se que nele estão presentes os requisitos para a configuração do dever de indenizar: ação ou omissão voluntária, relação de causalidade ou nexo causal, dano e, finalmente, culpa" (Direito Civil - Responsabilidade Civil, v. 4, $10^{\mathrm{a}}$ ed., São Paulo, Atlas, 2010, p. 6).
} 
Nos tópicos abaixo, será examinada a aplicação de cada um desses quatro pressupostos à hipótese específica de responsabilidade civil por danos decorrentes da prática de cartel.

\subsubsection{Ato ilícito}

O primeiro dos pressupostos da responsabilidade civil é a existência de um ato ilícito, conforme definido pelo artigo 186 do Código Civil, acima transcrito. A doutrina civilista conceitua o ato ilícito como uma conduta (por ação ou omissão) contrária ao ordenamento jurídico $^{198}$.

O artigo 187 do Código Civil dispõe ainda que "também comete ato ilícito o titular de um direito que, ao exercê-lo, excede manifestamente os limites impostos pelo seu fim econômico ou social, pela boa-fé ou pelos bons costumes". Trata-se da noção de abuso de direito, que consiste na conduta do agente que, embora atue no exercício de direito, exorbita dos fins econômicos e sociais que justificaram o reconhecimento do direito pelo ordenamento jurídico ${ }^{199}$.

Desse modo, há caracterização de ato ilícito no direito brasileiro nas seguintes hipóteses: (i) o agente viola diretamente os limites objetivos impostos pelo ordenamento jurídico (artigo 186 do Código Civil); ou (ii) mesmo atuando dentro dos limites objetivos da norma jurídica, o agente viola os fins econômicos e sociais do direito de que é titular, cometendo abuso de direito (artigo 187 do Código Civil). Ambas as

\footnotetext{
${ }^{198}$ CAIO MÁRIO DA Silva PEREIRA escreve que "sempre que alguém falta ao dever a que é adstrito, comete um ato ilícito, e como os deveres, qualquer que seja sua causa imediata, na realidade são sempre impostos pelos preceitos jurídicos, o ato ilícito importa na violação do ordenamento jurídico" (Instituições de Direito Civil, vol. I, $21^{a}$ ed., Rio de Janeiro, Forense, 2005, p. 654). RUI STOCO sustenta que "a só violação do direito já caracteriza o ato ilícito, independentemente de ter ocorrido dano. Ou seja, o ato ilícito é aquele praticado com infração de um dever legal ou contratual. Violar direito é cometer ato ilícito. A ilicitude está na só transgressão da norma" (Tratado de Responsabilidade Civil: Doutrina e Jurisprudência, $7^{\mathrm{a}}$ ed., São Paulo, Revista dos Tribunais, 2007, p. 120). ÁlVARO VILLAÇA AZEVEDO ensina que "os pressupostos fundamentais do ato ilícito residem na contrariedade a direito, ou seja infração de princípio do ordenamento jurídico, que é pressuposto objetivo, bem como ter sido previsível ou afastável o resultado" ("Conceito de Ato Ilícito e o Abuso de Direito", in Octávio Luiz Rodrigues Júnior, Gladston MAmede e Maria Vital Rocha (coord.), Reponsabilidade Civil Contemporânea ..., cit., p. 63).

${ }^{199}$ SILVIO RODRIGUES ensina que "aquele que exorbita no exercício de seu direito, causando prejuízos a outrem, pratica ato ilícito, ficando obrigado a reparar. Ele não viola os limites objetivos da lei, mas, embora lhes obedeça, desvia-se dos fins sociais a que esta se destina, do espírito que a norteia" (Direito Civil Responsabilidade Civil, vol. 4, 20ª ed., São Paulo, Saraiva, 2003, p. 46).
} 
situações fazem surgir o dever de reparação dos prejuízos, nos termos do artigo 927 do Código Civil, acima transcrito, que faz expressa remissão aos artigos 186 e 187.

O ato ilícito constitui elemento essencial da responsabilidade civil, eis que, ainda que tenha ocorrido dano, em princípio não haverá dever de indenizar a menos que tenha havido violação a um dever jurídico ou abuso de direito por parte do agente causador do dano.

Para ilustrar essa noção, SÉRGIO CAVALIERI FILHO menciona como exemplo uma situação relacionada ao direito da concorrência, afirmando que, ainda que um comerciante cause prejuízo ao seu concorrente, em razão da diminuição do movimento e dos lucros em virtude da instalação de seu comércio em local próximo, não haverá dever de indenizar a menos que o comerciante cometa algum ato ilícito (por exemplo, ato de concorrência desleal) ${ }^{200}$.

No mesmo sentido, Silvio Rodrigues esclarece que, no âmbito do direito da concorrência "enquanto não usa de processos ilegais, o que caracteriza a concorrência desleal, é legítimo que um comerciante dispute com outro, de igual ramo, a clientela que ambos pretendem", reconhecendo que "do lucro de um ordinariamente resultará o prejuízo de outro",201.

Especificamente em relação ao cartel, o ato ilícito consiste, como visto no capítulo 2, no acordo entre concorrentes com o objetivo de eliminar a competição entre si e fixar conjuntamente preços e quantidades, dividir mercados ou fraudar o caráter competitivo de licitações. São aplicáveis aqui as considerações feitas no capítulo 2, no qual

\footnotetext{
${ }^{200}$ Veja-se o ensinamento do autor: “(...) a responsabilidade tem por campo de incidência, ressalvadas eventuais exceções, o ato ilícito civil ou penal. Seu elemento nuclear é o descumprimento de um dever jurídico por uma conduta voluntária do agente, ensejando para este, quando acarreta dano para outrem, o dever de responder pelas consequências jurídicas daí decorrentes. De onde se conclui que não basta, para ensejar o dever de indenizar, a prática de um ato prejudicial aos interesses de outrem; é indispensável a ilicitude - violação de dever jurídico preexistente. Se alguém, por exemplo, instala o seu comércio perto de outro do mesmo ramo, poderá causar prejuízo ao dono deste último diminuindo-lhe o movimento e os lucros, mas nada terá que lhe indenizar, por não ter violado nenhum dever jurídico. A ilicitude só surgirá - e, consequentemente, o dever de indenizar - se vier a praticar concorrência desleal" (Programa de Responsabilidade Civil, $9^{\mathrm{a}}$ ed., São Paulo, Malheiros, 2010, p. 12).

${ }^{201}$ Direito Civil-Responsabilidade Civil, cit., p. 43.
} 
foram examinados em detalhes os pressupostos para a caracterização da infração à ordem econômica de cartel no direito brasileiro.

$\mathrm{Na}$ doutrina brasileira, não há consenso se o dever de reparar os danos causados pelo cartel é fundado na prática de ato ilícito, entendido como violação direta ao ordenamento jurídico (como conceituado no artigo 186 do Código Civil) ou se decorre de prática caracterizada pelo abuso de direito (conforme previsto no artigo 187 do Código Civil).

Bruno Oliveira MAGGi sustenta que o cartel consiste em violação direta do ordenamento jurídico ${ }^{202}$ :

"no caso dos cartéis (...) há violação de norma jurídica porque a Lei $\mathrm{n}^{\circ}$ 8.137/1990 determina que o cartel é um crime contra a ordem econômica em seu artigo $4^{\circ}$ e a Lei ${ }^{\circ}$ 8.884/1994 considera essa prática uma infração à ordem econômica em seus artigos 20 e 21 ".

Por outro lado, TÉRCIO SAMPAIO FERRAZ JÚNIOR ${ }^{203-204}$ defende que, no caso de cartel, é fundamental a noção de abuso de direito, sustentando que:

“em consonância com o dispositivo constitucional (art. 173, § $4^{\circ}$ ), mesmo o ato que obedece aos limites da lei, mas que, no exercício do direito, viola princípios de finalidade econômica da instituição social do mercado, produzindo um desequilíbrio entre o interesse individual e o da coletividade, constitui um abuso do poder econômico".

De qualquer modo, a consequência jurídica da prática de cartel no âmbito civil, seja ela considerada como uma violação direta do ordenamento jurídico, seja ela considerada como abuso de direito, é a mesma, qual seja, o dever do agente que participou do cartel de reparar os danos decorrentes do ato ilícito.

\footnotetext{
${ }^{202}$ O Cartel e seus Efeitos no Âmbito da Responsabilidade Civil, cit., p. 123.

203 "Direito da Concorrência e Enforcement Privado na Legislação Brasileira", cit., p. 14.

204 No mesmo sentido: LuIZ CARlos BuCHAIN, O Poder Econômico e a Responsabilidade Civil Concorrencial, cit., pp. 136-136; e ANDRÉ MARQUES FRANCISCO, Responsabilidade Civil por Infração da Ordem Econômica, cit., pp. 76-77.
} 


\subsubsection{1 "Stand-alone suits" e “follow-on suits": caráter vinculante da decisão condenatória na esfera penal e independência da decisão na esfera administrativa}

No âmbito da discussão sobre o ato ilícito de cartel, é importante fazer referência à distinção, feita pela doutrina estrangeira, entre as chamadas "stand-alone suits" e as chamadas "follow-on suits".

As "stand alone suits" são as demandas indenizatórias ajuizadas sem que haja qualquer investigação ou decisão prévia por parte das autoridades de defesa da concorrência com relação à infração concorrencial em questão. As "folow-on suits", por sua vez, são as demandas indenizatórias ajuizadas na esteira de investigação ou decisão por parte das autoridades concorrenciais.

Em alguns países (por exemplo, Inglaterra e Alemanha), a existência de decisão condenatória por autoridades de defesa da concorrência é vinculante perante o juízo cível com relação à existência do cartel, cabendo ao autor provar apenas a ocorrência de dano e o nexo causal ${ }^{205}$. Nesse mesmo sentido, a Diretiva da União Europeia sobre o tema prevê que as legislações de todos os Estados Membros deverão assegurar que as decisões finais das respectivas autoridades concorrenciais nacionais sejam consideradas, em demandas indenizatórias, como prova irrefutável da ocorrência de uma infração.

No direito brasileiro, caso tenha sido proferida decisão condenatória na esfera penal reconhecendo a prática do cartel, tal decisão será vinculante na esfera civil no tocante à existência do fato e sua autoria, restando aos litigantes discutir a existência de dano e nexo causal, a teor do disposto no art. 935 do Código Civil ${ }^{206-207}$.

\footnotetext{
${ }^{205}$ GIORGIO MONTI, escrevendo sobre as ações de indenização no âmbito da União Europeia, esclarece que "Follow-on claimants have a somewhat easier route to claim. In some jurisdictions (e.g. the UK and Germany) the national court is bound by the findings of a competition authority. (...) The plaintiff in a standalone action instead bears the burden of identifying the breach" (EC Competition Law, cit., p. 435).

206 “Art. 935. A responsabilidade civil é independente da criminal, não se podendo questionar mais sobre a existência do fato, ou sobre quem seja o seu autor, quando estas questões se acharem decididas no juízo criminal".

${ }^{207}$ Como esclarece CARLOS RoBERTO GONÇALVES, "se a infração penal houver acarretado dano, a sentença condenatória terá também o efeito de tornar certa a obrigação de o indenizar. Para condenar, o juiz criminal se pronuncia sobre a existência do fato, admitindo-o e definindo também quem é o seu autor. Não pode haver sentença condenatória sem prova da existência do fato e da sua autoria. Assim, em face do disposto na
} 
Na jurisprudência brasileira, esse dispositivo foi aplicado na sentença condenatória proferida na ação civil pública ajuizada pelo Ministério Público do Rio Grande do Sul pleiteando a reparação dos danos causados em virtude de cartel na revenda de combustíveis no Município de Santa Maria, tendo o juízo entendido que, com relação aos indivíduos condenados na esfera penal, não cabia discussão quanto à existência da prática de cartel ${ }^{208-209}$.

Por outro lado, caso tenha sido proferida decisão condenatória pelo CADE, a decisão administrativa não possui caráter vinculante perante o juízo cível, que poderá ter entendimento diverso do CADE com relação à existência da conduta ilícita. Essa conclusão decorre do princípio da inafastabilidade do Poder Judiciário, expresso no artigo $5^{\circ}$, inciso XXXV da Constituição Federal ${ }^{210}$. Trata-se, além disso, de regra expressa no artigo 47 da Lei 12.529/2011, segundo o qual a reparação dos prejuízos decorrentes de infração à ordem econômica se dá "independentemente do inquérito ou processo administrativo, que não será suspenso em virtude do ajuizamento de ação"211.

segunda parte do art. 935 do Código Civil, movida a ação cível, não poderão mais ser discutidas a existência do fato e a questão da autoria, pois tais circunstâncias já estão decididas no crime e produzem efeito absoluto no cível" (Responsabilidade Civil, cit., p. 588).

208 "Relativamente à existência de cartel no caso concreto, a esfera criminal - processo 027/2.05.0011599-0 já pacificou a celeuma no tocante a alguns réus que também figuram no polo passivo deste feito, entendendo pela existência do ato ilícito na cidade de Santa Maria. Assim, foram condenados Arlindo dos Santos Dutra, Volmar Rosa Peixoto, Irineu João Barichello, Volmir Dutra da Silva e Ivo Santa Lúcia como incursos nas sanções do artigo $4^{\circ}$, inciso II, alínea 'a', da Lei n' 8137/90. Logo, com relação a estes acusados, não há mais que perquirir se praticaram ou não cartel com relação ao preço dos combustíveis em Santa Maria, no período relatado na inicial. Já foi reconhecida a existência do fato ilícito, tendo a decisão transitado em julgado" (Ação Civil Pública no 027/1.05.0004158-2, 14 ${ }^{\mathrm{a}}$ Vara Cível de Santa Maria-RS, Arlindo dos Santos Dutra e outros, j. 28.12.2010).

${ }^{209}$ Com relação aos efeitos da sentença absolutória proferida na esfera penal sobre o juízo cível, RUI STOCO esclarece que "ocorrendo a absolvição do autor do fato no âmbito criminal, deve-se respeitar a independência das jurisdições. Desse modo, aquela decisão somente exercerá influência e supremacia no cível no que for comum às duas jurisdições (materialidade e autoria). Assim, em tese, o fato ou aspecto que não tenha sido objeto de apreciação e categoricamente afirmado ou negado no âmbito criminal não terá sido objeto de julgamento, permitindo sua reapreciação no juízo cível” (Tratado de Responsabilidade Civil..., cit., p. 263).

210 “Art. $5^{\circ}$ (...) XXXV - a lei não excluirá da apreciação do Poder Judiciário lesão ou ameaça a direito”.

211 Comentando o artigo 29 da lei concorrencial anterior (Lei 8.884/94), FÁBIO UlHÔA COELHO escreve o seguinte: "O legislador preocupou-se em ressalvar que a responsabilização administrativa do empresário, por infração contra a ordem econômica, é totalmente independente da civil e penal, em razão da mesma conduta. A absolvição ou a condenação do empresário em nível administrativo não implica a responsabilização ou não do mesmo agente nas esferas de direito civil e penal" (Direito Antitruste Brasileiro - Comentários à Lei $n^{o}$ 8.884/94, São Paulo, Saraiva, 1995, p. 48). A regra em questão é criticada por JoÃo BoSCO LEOPOLDINO DA FONSECA: "A boa técnica processual e a boa política administrativa e judicial exigem que, existindo perante juízos distintos demandas de igual teor, uma delas seja paralisada até julgamento da outra, para que se evitem julgamentos conflitantes. Vê-se, pois, que a disposição final do artigo não foi feliz, pois certamente 
Na jurisprudência, encontram-se precedentes em ambos os sentidos, a saber:

(i) casos em que o juízo da ação indenizatória, não obstante a existência de condenação administrativa, discordou do CADE e entendeu que não houve qualquer conduta ilícita ${ }^{212}$; e (b) casos em que o juízo cível considerou a decisão condenatória do CADE como evidência significativa da prática de cartel $^{213}$.

Na doutrina, Roberto Augusto Castellanos PFeiffer, escrevendo sobre o artigo 29 da lei concorrencial anterior (Lei 8.884/1994), que continha disposição semelhante, reconhece a independência da ação de reparação em relação ao processo administrativo do CADE, mas faz a seguinte ponderação ${ }^{214}$ :

"nos casos em que o CADE houver previamente decidido pela existência da infração, a tarefa do Juiz da causa será mais simples, pois bastará analisar a razoabilidade da decisão do CADE e adotar (caso também julgue que

proporcionará a existência de decisões conflitantes, com evidente e consequente desprestígio para os órgãos judicantes e desdouro para a lei" (Lei de Proteção da Concorrência - Comentários à Legislação Antitruste, cit., pp. 290-291).

${ }^{212}$ Embora se trate de caso envolvendo infração à ordem econômica distinta do cartel, pode ser mencionado como exemplo da independência entre as esferas cível e administrativa o julgamento da ação indenizatória ajuizada em face do Center Norte S.A., na esteira de decisão do CADE que havia concluído pela ilicitude da imposição de cláusula de raio em shopping centers. A demanda indenizatória foi julgada improcedente em primeira instância, em decisão mantida pelo Tribunal de Justiça de São Paulo, que concluiu o seguinte: “A exigência de cumprimento da cláusula de raio pelo recorrido, por outro lado, encerra, em princípio, exercício regular de direito (...). Não impressiona, de outra parte, a alegação de que a Secretaria de Direito Econômico (SDE) e o Conselho Administrativo de Defesa Econômica (CADE) já reconheceram que a cláusula de raio encerra prática abusiva, que afronta a livre concorrência (fls. 09). A decisão administrativa editada, notadamente aquela emanada do CADE, é alvo de questionamento perante a $24^{\mathrm{a}}$ Vara Federal de São Paulo, não servindo de lastro para o pronto reconhecimento de qualquer prática abusiva por parte do requerido. Independentes, ademais, as instâncias judicial e administrativa, de modo que a decisão do CADE não produz em Juízo os efeitos pretendidos pelos apelantes, sem dizer, ainda, a ausência de qualquer pronunciamento judicial acerca da invalidade da cláusula de raio (...)" (TJ/SP, Apelação Cível com Revisão no 546.327-4/900, Condomínio Shopping Center D e outros, $3^{\mathrm{a}}$ Câmara de Direito Privado, Rel. Des. Donegá Marandini, j. 10.03.2009).

${ }^{213}$ Embora não se trate de decisão definitiva, pode-se mencionar como exemplo a decisão proferida nos autos da ação ajuizada pela Associação de Hospitais de Minas Gerais em face das empresas do mercado de gases industriais. Inicialmente, foi indeferida pedido de antecipação de tutela formulado pela autora para que as rés se abstivessem de praticar alegado sobrepreço. Posteriormente, após ser juntada aos autos decisão do CADE que condenou as rés em processo administrativo, a juíza reconsiderou a decisão e concedeu a antecipação de tutela requerida. Veja-se o teor da decisão: "Diante da notícia nos autos do julgamento do Processo Administrativo ${ }^{\circ}$ 08012.009888/2003-70, no qual foi prolatada decisão condenando os Réus ao pagamento de pesadas multas, dentre outras penalidades, impõe-se a reapreciação do pedido. (...) Torna-se inconteste as condutas atribuídas às empresas Demandadas de prática de infração à ordem econômica, com a formação de cartel, o que foi esmiuçado no Processo Administrativo, culminando com a condenação das Requeridas por formação de cartel (...)" (Ação Ordinária nº 002409709934-5, Associação de Hospitais de Minas Gerais AHMG, Air Liquide Brasil Ltda. e outras, $20^{\circ}$ Vara Cível da comarca de Belo Horizonte - MG).

${ }^{214}$ Defesa da Concorrência e Bem-Estar do Consumidor, cit., p. 263. 
ocorreu infração contra a ordem econômica) ou rejeitar (caso conclua pelo caráter ilícito da conduta) os seus fundamentos".

LUIZ CARLOS Buchain, por sua vez, também reconhece o caráter não vinculante da decisão do CADE, mas sustenta, de lege ferenda, a adoção no Brasil de modelo pelo qual a decisão do $\mathrm{CADE}$ seja vinculante no juízo cível com relação à existência da infração à ordem econômica, de modo que, em havendo decisão condenatória na esfera administrativa, restaria ao demandante discutir a existência de dano e nexo causal. O autor reconhece, contudo, que a adoção do modelo proposto dependeria de reforma constitucional, tendo em vista o princípio constitucional da inafastabilidade do Poder Judiciário, acima mencionado ${ }^{215}$.

Essa proposta será examinada no capítulo 6, que analisará de maneira consolidada as diversas propostas de reforma do ordenamento jurídico brasileiro que têm por objetivo aperfeiçoar o sistema de responsabilidade civil por danos decorrentes da prática de cartel.

\subsubsection{Culpa}

Em face da teoria clássica, a culpa - em sentido amplo, abrangendo tanto a conduta involuntária como a dolosa - constitui um dos pressupostos da responsabilidade civil $^{216}$. A noção de culpa está expressa no art. 186 do Código Civil, que fundamenta o dever de reparação na "ação ou omissão voluntária, negligência ou imprudência".

Como decorrência da multiplicação dos riscos na sociedade moderna e das dificuldades de se demonstrar a culpa em determinadas situações, o pressuposto da culpa,

\footnotetext{
${ }^{215}$ O Poder Econômico e a Responsabilidade Civil Concorrencial, cit., pp. 126-127.

${ }^{216}$ Como ensina WAShington DE BARRos MonTEIRo "em princípio, para que se conceda a reparação, preciso é que o respectivo fato gerador seja moralmente imputável ao seu autor, isto é, que origine de sua vontade determinada ou de sua atividade consciente. Na ausência de culpa, que não se presume, improcederá o pedido de composição do dano formulado pela vítima. (...) Aí está, portanto, em linhas gerais, a base sobre a qual repousa a teoria clássica e tradicional da culpa, também chamada teoria da responsabilidade subjetiva, que pressupõe sempre a existência de culpa (lato sensu), abrangendo o dolo (pleno conhecimento do mal e direta intenção de o praticar) e a culpa (strictu sensu), violação de um dever que o agente podia conhecer e acatar" (Curso de Direito Civil: Direito das Obrigações, $2^{a}$ Parte, $9^{a}$ ed., São Paulo, Saraiva, 1973, p. 388).
} 
embora não tenha sido abandonado, foi paulatinamente cedendo espaço à ideia de responsabilidade sem culpa ${ }^{217}$.

Atualmente, o parágrafo único do art. 927 do Código Civil, estabelece que "haverá obrigação de reparar o dano, independentemente de culpa, nos casos especificados em lei, ou quando a atividade normalmente desenvolvida pelo autor do dano implicar, por sua natureza, risco para os direitos de outrem.”. Em referidas hipóteses, a responsabilidade é dita "objetiva", configurando-se apenas mediante a existência da conduta e a demonstração de dano e nexo causal ${ }^{218}$.

A partir da análise do mencionado dispositivo, é preciso examinar se a responsabilidade civil pela prática de infração à ordem econômica, tal como a prática de cartel, configura hipótese de responsabilidade objetiva ou subjetiva.

Como visto, o parágrafo único do art. 927 do Código Civil prevê a responsabilidade sem culpa "nos casos especificados em lei". Nesse sentido, a Lei 12.529/2011 dispõe expressamente que a infração à ordem econômica ocorre

\footnotetext{
${ }^{217}$ Sobre a noção de responsabilidade sem culpa, confira-se a lição de ALVINO LIMA: "Dentro do critério da responsabilidade fundada na culpa não era possível resolver um sem-número de casos que a civilização moderna criara ou agravara; imprescindível se tornara, para a solução do problema da responsabilidade extracontratual, afastar-se do elemento moral, da pesquisa psicológica, do íntimo do agente, ou da possibilidade de previsão ou de diligência, para colocar a questão sob um aspecto até então não encarado devidamente, isto é, sob o ponto de vista exclusivo da reparação do dano. O fim por atingir é exterior, objetivo de simples reparação e não interior e subjetivo como na imposição da pena. Os problemas da responsabilidade são tão-somente os problemas da reparação de perdas. O dano e a reparação não devem ser aferidos pela medida da culpabilidade, mas devem emergir do fato causador da lesão de um bem jurídico, a fim de se manterem incólumes os interesses em jogo, cujo desequilíbrio é manifesto, se ficarmos dentro dos estreitos limites de uma responsabilidade subjetiva. (...) A responsabilidade deve surgir exclusivamente do fato, considerando-se a culpa um resquício da confusão primitiva entre a responsabilidade civil e a penal. $\mathrm{O}$ que se deve ter em vista é a vítima, assegurando-lhe a reparação do dano e não a ideia de infligir uma pena ao autor do prejuízo causado. Os dados econômicos modernos determinam a responsabilidade fundada sobre a lei econômica da "causalidade entre o proveito e o risco"' (Culpa e Risco, São Paulo, Revista dos Tribunais, 1960, pp. 119-121).

${ }^{218}$ A respeito do tema, CARLOS ROBERTO GONÇALVES ensina: "Em face da teoria clássica, a culpa era fundamento da responsabilidade. Esta teoria, também chamada de teoria da culpa, ou "subjetiva", pressupõe a culpa como fundamento da responsabilidade civil. Em não havendo culpa, não há responsabilidade. (...) A lei impõe, entretanto, a certas pessoas, a reparação de um dano cometido sem culpa. Quando acontece, diz-se que a responsabilidade é legal ou 'objetiva', pois prescinde da culpa e se satisfaz apenas com o dano e o nexo de causalidade" (Responsabilidade Civil, cit., p. 54).
} 
"independentemente de culpa" (art. 36) e, ao mesmo tempo, assegura o direito dos prejudicados por referidas infrações ao ressarcimento dos prejuízos decorrentes (art. 47) ${ }^{219}$.

Com fundamento na conjugação desses dispositivos, é possível sustentar que a responsabilidade civil por danos decorrentes de infrações à ordem econômica, incluindo a prática de cartel, prescinde da demonstração do elemento culpa, bastando a demonstração da existência do cartel (ato ilícito, examinado acima), do dano e do nexo causal $^{220}$.

O entendimento de que a responsabilidade civil por danos decorrentes de cartéis e outras infrações à ordem econômica configura hipótese de responsabilidade objetiva é consolidado na doutrina brasileira.

Nesse sentido, TÉrcio SAMPAIO FERraZ JÚNIOR, após destacar que a existência de norma expressa na lei concorrencial assegurando a reparação dos danos (art. 47) não deve ser reduzida a uma simples repetição da regra do Código Civil, pois viabiliza a aplicação dos princípios da lei concorrencial no âmbito da responsabilidade civil antitruste, conclui que "mesmo em sede de ação individual de indenização por violação de norma concorrencial não há derrogação do princípio da responsabilidade objetiva por efeitos que se produzam ou possam ser produzidos",221.

\footnotetext{
${ }^{219}$ FÁBIO ULHÔA COELHO esclarece que "trata-se, aqui, de responsabilidade civil do empresário em razão da mesma conduta caracterizada como ilícito administrativo pela lei" (Direito Antitruste Brasileiro Comentários à Lei $n^{\circ} 8.884 / 94$, cit., p. 97).

${ }^{220}$ Também se poderia cogitar da existência de responsabilidade objetiva em decorrência da teoria do risco, expressa na parte final do parágrafo único do art. 927 ("quando a atividade normalmente desenvolvida pelo autor do dano implicar, por sua natureza, risco para os direitos de outrem"). Nesse ponto, embora haja certa divergência na doutrina sobre a interpretação do dispositivo, a responsabilidade objetiva nesses casos decorre de um risco que seja inerente à natureza da atividade desenvolvida (SILVIo DE SALVo VENOSA, Direito Civil - Responsabilidade Civil, cit., pp. 10-11). Tal descrição não se amolda à responsabilidade civil pela prática de cartel, que decorre de um ilícito cometido pelos infratores com o objetivo de aumentar os lucros, não guardando qualquer relação com a natureza da atividade normalmente desenvolvida pelas empresas cartelizadas. Por esse motivo, entende-se que a teoria do risco não constitui fundamento adequado para justificar o caráter objetivo da responsabilidade civil por cartel.

221 "Direito da Concorrência e Enforcement Privado na Legislação Brasileira”, cit., pp. 19-21.
} 
No mesmo sentido, Roberto Augusto CASTEllanos PFeIfFer, escrevendo sobre o dispositivo da lei concorrencial anterior, também defende a natureza objetiva da responsabilidade civil por infrações à ordem econômica ${ }^{222-223}$.

Essa conclusão, contudo, não se aplica no caso da responsabilidade dos administradores das empresas pela prática de infração à ordem econômica, hipótese em que, conforme analisado no capítulo 2, a lei concorrencial expressamente dispõe que somente haverá responsabilização "quando comprovada a sua culpa ou dolo" (Lei 12.529/2011, art. 37, inc. III). Como destacado no capítulo 2, a exigência de demonstração de culpa ou dolo também pode ser aplicada por analogia no caso das "demais pessoas físicas” (Lei 12.529/2011, art. 37, inc. II) envolvidas na prática de cartel.

Especificamente com relação às demandas movidas por consumidores diretamente ou mediante substituição processual na tutela coletiva - a responsabilidade objetiva também pode ser sustentada com base nos artigos 12 e 14 do Código de Defesa do Consumidor, que preveem a responsabilidade objetiva do fornecedor por danos causados aos consumidores em decorrência da relação de consumo ${ }^{224}$.

Por fim, deve-se comentar que a relevância prática da discussão tende a ser atenuada em muitas das ações de indenização por danos decorrentes da prática de cartel, especialmente naqueles casos que envolvam um acordo expresso entre concorrentes. Nessas hipóteses, tratar-se-á em geral de conduta voluntária praticada com o objetivo de aumentar o lucro dos infratores, os quais têm consciência da ilicitude e em muitos casos chegam inclusive a tomar medidas para evitar que a prática chegue ao conhecimento das autoridades. Desse modo, embora a responsabilidade prescinda da demonstração de dolo

\footnotetext{
${ }^{222}$ Defesa da Concorrência e Bem-Estar do Consumidor, cit., p. 250.

223 No mesmo sentido, vide: BRUNO OLIVEIRA MAGGI, O Cartel e seus Efeitos no Âmbito da Responsabilidade Civil, cit., p. 175; LUIZ CARLOS BUCHAIN, O Poder Econômico e a Responsabilidade Civil Concorrencial, cit., p 137; e PAUlO FELIPE CARNEIRO DE FREITAS, Tutela Coletiva da Responsabilidade Civil por Infração da Ordem Econômica, cit., p. 68.

224 NELSON NERY JÚNIOR e ROSA MARIA DE ANDRADE NERY defendem que "não havendo, na norma comentada, exigência da demonstração da conduta (dolo ou culpa) do agente para que ocorra o dever de indenizar, a conclusão é de que foi adotada a responsabilidade objetiva como sendo o sistema geral da responsabilidade do CDC. Assim, toda indenização derivada da relação de consumo sujeita-se ao regime de responsabilidade objetiva, salvo quando o Código expressamente disponha em contrário, como fez, v.g., no CDC, $14 \S 4^{\circ}$ " (Leis Civis Comentadas, São Paulo, Revista dos Tribunais, 2012, p. 269). A respeito da responsabilidade objetiva no âmbito das relações de consumo, ver também: RoBERTO SENISE LISBOA, Responsabilidade Civil nas Relações de Consumo, São Paulo, Revista dos Tribunais, 2001, pp. 15-43.
} 
ou culpa, nos casos envolvendo acordo expresso, uma vez provado o cartel, o dolo dos infratores tende a estar evidente a partir dos elementos do caso. Com relação às hipóteses acima discutidas de acordo tácito, contudo, a discussão sobre a exigência de dolo ou culpa tem bastante relevância prática ${ }^{225}$.

\subsubsection{Nexo causal}

Para que fique configurada a responsabilidade civil, não é suficiente a prática de um ato ilícito causador de um dano. É necessário, ainda, que haja relação de causa e efeito entre o ato e o resultado danoso. Trata-se de exigência expressa do artigo 927 do Código Civil, que impõe o dever de indenizar a todo aquele que, por ato ilícito, causar dano a outrem.

O nexo causal constitui elemento indispensável da responsabilidade civil ${ }^{226}$, tendo assumido grande relevância no direito contemporâneo por conta da ampliação das hipóteses de responsabilidade sem culpa ${ }^{227}$. As principais teorias construídas para explicar o nexo de causalidade são as seguintes:

i) teoria da equivalência das condições (também chamada de "conditio sine qua non”), segundo a qual todas as condições antecedentes que contribuíram para o

225 CALIXTO SAlOMÃo FILHO escreve que, nas hipóteses de acordo tácito, não é necessário que os administradores da empresa tenham ciência e/ou intenção de coludir para que a conduta seja considerada como infração à ordem econômica. Nas palavras do autor: "Note-se que, nesse caso [comportamento paralelo intencional], não é necessário que os administradores saibam e/ou tenham a intenção de coludir. Importa isso, sim - que a empresa tenha aprendido e incluído no seu plano empresarial a noção de colusão" (Direito Concorrencial-As Condutas, cit., p. 278).

${ }^{226}$ Como ensina SÉRGIO CAVALIERI FILHO, "não basta, portanto, que o agente tenha praticado uma conduta ilícita; tampouco que a vítima tenha sofrido um dano. É preciso que esse dano tenha sido causado pela conduta ilícita do agente, que exista entre ambos uma necessária relação de causa e efeito. Em síntese, é necessário que o ato ilícito seja a causa do dano, que o prejuízo sofrido pela vítima seja resultado desse ato, sem o que a responsabilidade não correrá a cargo do autor material do ato. Daí a relevância do chamado nexo causal." (Programa de Responsabilidade Civil, cit., p. 47). Sobre o requisito do nexo de causalidade para configuração da responsabilidade civil, vide: GISELA SAMPAIO DA CRUZ, O Problema do Nexo Causal na Responsabilidade Civil, Rio de Janeiro, Renovar, 2005.

${ }^{227}$ GuSTAVo TEPEDINO escreve que "diante do desprestígio do papel da culpa, inapta a servir de critério seguro ao julgador na determinação do dever de reparar, o conceito de nexo de causalidade assume extraordinária importância no estudo da responsabilidade civil. Na medida em que a demonstração da ocorrência da atividade danosa, do dano e do nexo de causalidade parecem suficientes para a deflagração do dever de reparar - fenômeno que resulta em notória expansão dos danos ressarcíveis -, a identificação da causalidade torna-se o cerne da reflexão" ("Nexo de Causalidade - Conceito, Teorias e Aplicação na Jurisprudência Brasileira", in OCTÁVIO LuIZ RodRIGUES JÚNIOR, GLADSTON MAMEdE e MARIA VITAL RocHA (coord.), Reponsabilidade Civil Contemporânea..., cit., p. 107). 
resultado devem ser consideradas como causa do dano; essa teoria, embora tenha por vantagem a simplicidade (favorecendo assim a reparação da vítima), tem o inconveniente de ampliar de modo ilimitado a responsabilização do dano, que pode ser imputado a todos agentes que, mesmo que remotamente, tenham relação com o resultado danoso: no exemplo de FÁBIo MARCo Morsello, “já se antevê, por outro lado, a problemática gerada por referido entendimento, na medida em que propiciaria regressão ilimitada do nexo causal, de modo que, e.g., nas hipóteses de acidente aéreo, chegaríamos ao ponto das origens dos inventores do avião" ${ }^{\text {,228; }}$ em razão desses inconvenientes, a teoria, embora útil no campo das ciências naturais, não é adotada no âmbito da responsabilidade civil;

ii) teoria da causalidade adequada, segundo a qual, na presença de mais de uma possível causa, procura-se identificar qual delas é a mais apta, em abstrato, segundo um parâmetro de "normalidade", a produzir o resultado danoso; essa teoria também foi objeto de críticas por resultar em indefinição com relação à causa do dano, que poderia ser imputada a qualquer causa que abstratamente pudesse ser entendida como apta a gerar o resultado danoso ${ }^{229}$;

iii) teoria da causalidade eficiente, segundo a qual, na presença de mais de uma possível causa, procura-se identificar, no caso concreto (e não em abstrato), qual delas foi mais eficiente para a produção do resultado danoso; essa teoria também foi criticada, uma vez que seus defensores, como esclarece ANDERSON SCHREIBER, “jamais lograram alcançar um acordo acerca dos critérios mais ou menos objetivos que permitissem selecionar, entre as diversas causas de um dano, aquela que teve o poder intrínseco de produzi-lo no caso concreto" ${ }^{230}$; e

iv) por fim, a teoria da causalidade direta e imediata (também chamada de teoria de interrupção do nexo causal), que leva em consideração apenas a causa diretamente relacionada ao dano, tendo sido positivada no art. 403 do Código Civil brasileiro: “Ainda que a inexecução resulte de dolo do devedor, as perdas e danos só incluem

\footnotetext{
228 “O Nexo Causal e Suas Distintas Teorias: Apreciações Críticas”, in Revista do Instituto dos Advogados de São Paulo, vol. 19, 2007, p. 211.

${ }^{229}$ ANDERSON SCHREIBER, Novos Paradigmas da Responsabilidade Civil..., cit., pp. 58-59.

${ }^{230}$ Novos Paradigmas da Responsabilidade Civil..., cit., p. 60.
} 
os prejuízos efetivos e os lucros cessantes por efeito dela direto e imediato, sem prejuízo do disposto na lei processual” ${ }^{, 231}$.

A teoria da causalidade direta e imediata deu origem à subteoria da necessariedade da causa, segundo a qual há dever de reparar quando o dano é efeito necessário de determinada causa, ainda que remota. Essa subteoria costuma prevalecer na jurisprudência brasileira ${ }^{232}$, embora, na prática, a análise dos julgados revele a aplicação de uma multiplicidade de teorias pelos tribunais, de acordo com as particularidades de cada caso concreto, num fenômeno descrito por ANDERSON SCHREIBER como "flexibilização do nexo causal"233-234.

No âmbito da responsabilidade civil por cartel, o nexo causal pressupõe a verificação de que o dano experimentado pela vítima foi decorrência do acordo ilícito celebrado entre os concorrentes com o objetivo de eliminar a competição entre si e aumentar artificialmente os lucros.

Uma questão interessante a ser examinada é a existência de nexo de causalidade entre a infração e o dano nas hipóteses em que não tenha existido relação contratual entre o demandante e o demandado. Com efeito, embora em muitos casos a relação entre aquele que pratica o cartel e a vítima do cartel seja disciplinada contratualmente (por exemplo, por meio de um contrato de compra e venda ou de prestação de serviços), em muitos casos o autor e a vítima do cartel não mantêm qualquer relação direta.

\footnotetext{
${ }^{231}$ Embora o dispositivo fale em "inexecução" das obrigações, o que poderia levar à conclusão de que sua aplicação é restrita ao campo da responsabilidade contratual, consolidou-se na jurisprudência entendimento de que a teoria da causalidade direta e imediata também é aplicável no âmbito da responsabilidade extracontratual. Nesse sentido, vide: STF, RE 130764, Rel. Min. Moreira Alves, Primeira Turma, julgado em 12.05.1992.

${ }^{232}$ De acordo com Gustavo TEPEDINO, "a despeito das teorias nominalmente adotadas pelos tribunais brasileiros, as decisões revelam-se substancialmente fundamentadas na teoria da necessariedade da causa, demonstrando que o dever de reparar advém da necessariedade existente entre o dano e a atividade" ("Nexo de Causalidade...", cit., p. 111).

${ }^{233}$ Novos Paradigmas da Responsabilidade Civil..., cit., pp. 53-79.

${ }^{234}$ No mesmo sentido, SILVIO DE SALVo VENOSA esclarece que, a respeito do nexo causal "nossos tribunais têm posição eclética, não havendo uma corrente definida preponderante a respeito da teoria mais adotada a respeito do nexo causal" (Direito Civil - Responsabilidade Civil, cit., p. 58).
} 
Nesse contexto, a primeira pergunta que se coloca é a seguinte: a vítima do cartel pode cobrar o prejuízo apenas do membro do cartel com quem manteve relação contratual (ou seja, apenas daquele de quem adquiriu os produtos ou serviços a preços cartelizados) ou também pode cobrar o prejuízo dos demais membros do cartel, mesmo daqueles com quem não manteve qualquer relação contratual? Em outras palavras, há nexo causal entre o prejuízo sofrido pela vítima do cartel e a conduta do membro do cartel que não vendeu qualquer produto ou serviço para aquela vítima específica (que, no exemplo em discussão, adquiriu-os de outro membro do cartel)?

Como visto anteriormente, tanto no direito norte-americano como no direito europeu, prevê-se a responsabilidade solidária de todos os membros do cartel, de modo que a vítima pode cobrar a indenização de qualquer um dos infratores, ainda que eventualmente não tenha adquirido produtos ou serviços de todos eles.

Para análise da questão no direito brasileiro, é importante ter presente que a responsabilidade civil por cartel possui natureza extracontratual (aquiliana) e não contratual $^{235}$. Embora, como visto, as relações entre o cartel e suas vítimas sejam em muitos casos reguladas contratualmente, o prejuízo gerado pelo cartel não resulta de qualquer violação contratual. Mesmo que o contrato seja cumprido e os preços e condições nele previstos sejam estritamente observados, ainda assim haverá prejuízo a ser indenizado, o qual decorre de um elemento externo aos contratos, qual seja, a infração à ordem econômica consubstanciada na combinação ilícita entre concorrentes resultando em aumento artificial dos preços ${ }^{236}$.

\footnotetext{
${ }^{235}$ Sobre a distinção entre responsabilidade civil contratual e extracontratual, SILVIO RODRIGUES esclarece que "muitos entendem que as duas responsabilidades são de igual natureza, não havendo por que disciplinálas separadamente. E, de fato, tanto na configuração da responsabilidade contratual como na da aquiliana vários dos pressupostos são comuns. Numa e noutra mister se faz a existência do dano, a culpa do agente e a relação de causalidade entre o comportamento do agente e o dano experimentado pela vítima ou pelo outro contratante." (Direito Civil - Responsabilidade Civil, cit., p. 9).

${ }^{236}$ Nesse sentido, BRUNo OliveIRA MAGGI escreve o seguinte: "No caso dos cartéis, a responsabilidade é extracontratual, pois o prejuízo gerado aos compradores não decorre da violação ao contrato de compra e venda celebrado com o fornecedor, sendo ele um dos cartelistas ou não. A origem do prejuízo está no acordo de cartel, fator externo aos negócios jurídicos individuais de compra e venda dos produtos." (O Cartel e seus Efeitos no Âmbito da Responsabilidade Civil, cit., p. 114). No mesmo sentido, veja-se a posição de PAULO FELIPE CARNEIRO DE FREITAS: "A responsabilidade civil concorrencial, objeto do presente trabalho, evidentemente, é aquiliana (ou extracontratual), pois se funda na prática de um ilícito antitruste como delineado na Lei da Concorrência, desrespeitando-se o padrão de comportamento esperado dos agentes no mercado" (Tutela Coletiva da Responsabilidade Civil por Infração da Ordem Econômica, cit., pp. 47-48).
} 
Assim, entende-se que há nexo causal - e, portanto, há dever de indenizar mesmo nos casos em que o prejudicado adquire os produtos ou serviços de um determinado membro do cartel e, não obstante, promova ação indenizatória contra os outros membros do cartel, com quem não manteve qualquer relação contratual. Isto porque o nexo causal a ser examinado é entre a celebração do cartel e o dano sofrido, independentemente das relações contratuais porventura existentes entre as partes ${ }^{237}$.

Nesse sentido, Bruno Oliveira MagGi defende que o pedido de indenização deve ser feito a qualquer dos membros do cartel, independentemente dos vínculos jurídicos eventualmente existentes entre os agentes do mercado ${ }^{238-239}$ :

\begin{abstract}
"Importante notar que o nexo causal não se confunde com o vínculo jurídico que eventualmente possa existir entre os agentes de mercado. Os contratos celebrados ao longo da cadeia produtiva pouco importam para a responsabilização pela prática de cartel, porque, além de a responsabilidade ser extracontratual, esses vínculos jurídicos não correspondem necessariamente ao nexo causal. (...) Independentemente dos vínculos jurídicos existentes, o nexo causal é a relação de causa e efeito entre as práticas de cartel e as alterações sofridas pelo mercado e liga o comprador ao cartelista, que praticou o ato ilícito. Portanto, os pedidos de indenização devem ser feitos diretamente pelo lesado aos membros do cartel".
\end{abstract}

Nesse contexto, no exemplo acima descrito, mesmo que o prejudicado tenha adquirido os produtos ou serviços de apenas um único participante do cartel, a conduta dos demais membros também guarda relação de causalidade com o dano experimentado, uma

\footnotetext{
${ }^{237}$ Não obstante se conclua pelo caráter extracontratual da responsabilidade civil por danos decorrentes da prática de cartel, na hipótese de o prejudicado ajuizar indenização em face do membro do cartel com quem contratou diretamente, o prejudicado poderá alegar também violação ao dever de boa-fé objetiva no âmbito contratual, previsto no artigo 422 do Código Civil, o qual dispõe que "os contratantes são obrigados a guardar, assim na conclusão do contrato, como em sua execução, os princípios de probidade e boa-fé". Sobre a boa-fé no direito civil, ANTONio MANUEl DA Rocha E MENEZES CORDEIRO menciona os "deveres acessórios de protecção" e sustenta que "por eles, considera-se que as partes, enquanto perdure um fenómeno contratual, estão ligadas a evitar que, no âmbito desse fenómeno, sejam infligidos danos mútuos, nas suas pessoas ou nos seus patrimônios" (Da Boa Fé no Direito Civil, $5^{\mathrm{a}}$ reimpressão, Coimbra, Almedina, 2013, p. 604).

${ }^{238}$ O Cartel e seus Efeitos no Âmbito da Responsabilidade Civil, cit., p. 165.

${ }^{239}$ No mesmo sentido, veja-se a posição de LUIZ CARLOS BUCHAIN: "Nas ações de indenização fundadas na violação da concorrência, o autor deverá provar que o dano sofrido resulta de atos praticados pelo agente econômico dominante no mercado e violador da concorrência. Esse dano não será necessária ou exclusivamente derivado da conduta do demandado, mas sim por ele causado, ainda que haja outros agentes no mercado ou outras situações que tenham contribuído para o dano. O exemplo típico é a existência de vários agentes econômicos partilhando o mesmo mercado, os quais representam as forças múltiplas e complexas que causam o dano ao prejudicado, sem que possam ser convenientemente isoladas" ( $O$ Poder Econômico e a Responsabilidade Civil Concorrencial, cit., pp. 140-141).
} 
vez que, na ausência do cartel, nenhuma das empresas teria condições de impor preços mais elevados aos adquirentes.

Desse modo, os diversos membros do cartel respondem solidariamente pelos prejuízos causados, nos termos do parágrafo único do art. 942 do Código Civil ${ }^{240}$, independentemente de terem ou não mantido relações diretas com o demandante. Caso um dos membros do cartel seja obrigado a pagar a integralidade da indenização, terá direito de regresso contra os demais infratores, nos termos do artigo 283 do Código Civil ${ }^{241}$.

Pela mesma razão, também estará preenchido o requisito do nexo causal na hipótese de os prejudicados não terem adquirido os produtos ou serviços diretamente de nenhum dos membros do cartel, tendo sofrido o repasse do sobrepreço (o chamado "passon") por parte de outro adquirente localizado em etapa anterior da cadeia produtiva. Neste segundo exemplo, embora os prejudicados não tenham mantido relações diretas com nenhum dos membros do cartel, caso fique provado que houve repasse do sobrepreço ( “pass-on”, já discutido no capítulo 4), haverá nexo de causalidade entre a conduta dos membros do cartel e o dano experimentado pelos compradores indiretos ${ }^{242}$. A questão do “pass-on” será examinada novamente adiante, no tópico que discute o dano.

\subsubsection{Excludentes de responsabilidade}

Com relação ao nexo causal, também cabe avaliar a eventual aplicação, no âmbito da responsabilidade civil por cartel, das excludentes de responsabilidade, as quais constituem eventos que afastam a relação de causalidade entre a ação do agente e o dano

\footnotetext{
240 “Art. 942. (...) Parágrafo único. São solidariamente responsáveis com os autores os co-autores e as pessoas designadas no art. 932.”. Nesse sentido: "In the event of a competition violation, Brazilian law provides that all the individuals involved in the conduct - for example, all the members of the cartel - shall answer jointly for the damages they caused" (CARlos Francisco DE MAGAlHÃES, GABriEl NogueIRA Dias e CRISTIANO Rodrigo Del Debbio, "Brazil", in Ilene Knable GotTs (org.), The Private Competition Enforcement Review, 4th ed., London, Law Business Research Ltd., 2011, p. 32).

241 “Art. 283. O devedor que satisfez a dívida por inteiro tem direito a exigir de cada um dos co-devedores a sua quota, dividindo-se igualmente por todos a do insolvente, se o houver, presumindo-se iguais, no débito, as partes de todos os co-devedores".

${ }^{242}$ Nesse sentido, confira-se o entendimento de PAUlo FELIPE CARNEIRO DE FreITAS: “(...) mesmo que um dano seja perpetrado no interior da cadeia produtiva, e houver prova do nexo causal adequado e de que ele foi repassado adiante, de rigor o reconhecimento da indenização" (Tutela Coletiva da Responsabilidade Civil por Infração da Ordem Econômica, cit., p. 65).
} 
experimentado pela vítima ${ }^{243}$. As principais excludentes de responsabilidade são o estado de necessidade, a legítima defesa, a culpa exclusiva da vítima, o fato de terceiro, o caso fortuito ou força maior ${ }^{244}$.

Sobre o assunto, BRuno OliveIRA MAGGi defende que as excludentes de responsabilidade não são aplicáveis às demandas envolvendo a prática de $\operatorname{cartel}^{245}$ :

\begin{abstract}
"A natureza da atividade do cartel impossibilita a aplicação dessas hipóteses, pois se trata de um ato que é praticado voluntariamente pelos agentes e depende de sua participação ativa. Tais práticas não ocorrem ao acaso e não se pode alegar que estariam fora do controle dos participantes do acordo, de modo que não podem ser decorrentes de eventos de caso fortuito ou força maior. Da mesma forma, não é possível haver culpa exclusiva da vítima, posto que os compradores em geral desconhecem a existência do cartel e ignoram o fato de pagarem mais caro pelos produtos ou serviços adquiridos. (...) Portanto, as excludentes de responsabilidade são incompatíveis com a própria essência do acordo de cartel e não há como qualquer uma dessas hipóteses eximir o participante do cartel da obrigação de reparar os danos gerados."
\end{abstract}

De fato, avaliando-se as hipóteses de excludente de responsabilidade, é possível concluir que tais hipóteses são de difícil aplicação à situação de cartel, sendo difícil imaginar como o dano decorrente do sobrepreço possa ser causado, por exemplo, por culpa exclusiva da vítima ou por caso fortuito e força maior. De qualquer modo, dada a multiplicidade de situações que possam vir a surgir, a avaliação definitiva acerca da aplicação das excludentes de responsabilidade sempre dependerá das circunstâncias de cada caso concreto ${ }^{246}$.

Nesse ponto, uma hipótese específica que merece ser avaliada é o chamado cartel de crise, formado em períodos de crise econômica com o suposto objetivo de evitar o excesso de capacidade, estabilizar preços e evitar o fechamento de empresas do mercado. Como apontado por ENRICO SPINI ROMANIELO em trabalho específico sobre o tema, a jurisprudência internacional e do CADE entendem, de modo geral, que eventual crise

\footnotetext{
243 "Conforme já foi dito acima, na maioria das hipóteses a presença de uma excludente de responsabilidade atenua ou extingue o dever de ressarcir, justamente por atenuar ou extinguir a relação de causalidade" (Silvio Rodrigues, Direito Civil - Responsabilidade Civil, cit., p. 164).

${ }^{244}$ Carlos Roberto GonÇALVES, Responsabilidade Civil, cit., pp. 624-625.

${ }^{245}$ O Cartel e seus Efeitos no Âmbito da Responsabilidade Civil, cit., p. 177.

${ }^{246}$ CARLOS ALBERTO BITTAR observa que "a prova da excludente, que compete ao imputado, deve ser efetivada com critério de segurança que permita a sua aceitação, eis que, diante de sua extensão, recomendase cautela ao julgador, lembrando que o reconhecimento pode significar a não atribuição de indenização à vítima" (Responsabilidade Civil: Teoria e Prática, 2ª ed., Rio de Janeiro, Forense Universitária, 1990).
} 
econômica não pode ser invocada como defesa para afastar a responsabilização pela prática de cartel, que, como adiantado, constitui a mais grave infração à ordem econômica ${ }^{247}$.

De modo análogo, entende-se que, em princípio, eventual crise econômica também não poderá ser invocada como excludente de responsabilidade em ações de indenização por danos decorrentes da prática de cartel, embora, conforme adiantado acima, a avaliação definitiva dependa das circunstâncias de cada caso concreto.

\subsubsection{Dano}

O dano ${ }^{248}$ é considerado pela doutrina como o elemento central da responsabilidade civil. Trata-se de requisito imprescindível sem o qual não se perfaz o dever de indenizar. Com efeito, embora seja possível que haja responsabilidade sem culpa, conforme visto acima, não se pode cogitar de responsabilidade civil sem que fique caracterizado o dano ${ }^{249}$.

$\mathrm{Na}$ concepção clássica, o dano era definido como toda e qualquer diminuição patrimonial, devendo ser apurado mediante a comparação entre o patrimônio

\footnotetext{
${ }^{247}$ O autor conclui que "os argumentos de cartel de crise não convencem", sustentando que "o CADE deveria manter seu posicionamento firme contra cartéis mesmo em tempos de crise, evitando, contudo, uma análise per se da conduta e, dessa forma, respeitando as particularidades de cada caso" (Direito Antitruste e Crise Perspectivas para a Realidade Brasileira, Dissertação de Mestrado, Faculdade de Direito da Universidade de São Paulo, 2013, p. 291).

${ }^{248}$ RUI STOCO esclarece que o termo "dano" vem do latim "damnun" e significa a ofensa causada a outrem que possa resultar redução ou deterioração à sua coisa ou prejuízo ao patrimônio (Tratado de Responsabilidade Civil..., cit., p. 1231).

${ }^{249}$ Como esclarece PHILIPPE LE TORNEAU, "Toutes les actions en responsabilité supposent un préjudice, un dommage. Pas de préjudice, pas de responsabilité civile. C'est l'application de l'adage: 'pas d'intéret, pas d'action"' (La Responsabilité Civile, $2^{\mathrm{a}}$ ed., Paris, Dalloz, 1976, p. 141). Na doutrina brasileira, vejam-se os ensinamentos de JOSÉ DE AGUIAR DIAS: "o dano é, dos elementos necessários à configuração da responsabilidade civil, o que suscita menos controvérsia. Com efeito, a unanimidade dos autores convém em que não pode haver responsabilidade sem a existência de um dano, e é verdadeiro truísmo sustentar esse princípio, porque, resultando a responsabilidade civil em obrigação de ressarcir, logicamente não pode concretizar-se onde nada há que reparar" (Da Responsabilidade Civil, vol. II, $7^{\mathrm{a}}$ ed., Forense, Rio de Janeiro, 1983, p. 792); RUI STOCO: "a direção a seguir é no sentido de priorizar o dano e considerá-lo como elemento fundamental, na medida em que a distinção entre responsabilidade objetiva e subjetiva e entre ato lícito e ilícito começa a ser relativizada (...)" (Tratado de Responsabilidade Civil..., cit., p. 1232); SÉRGIO CAVALIERI FILHO esclarece que "o dano é, sem dúvida, o grande vilão da responsabilidade civil. Não haveria que se falar em indenização, nem em ressarcimento, se não houvesse o dano. Pode haver responsabilidade sem culpa, mas não pode haver responsabilidade sem dano" (Programa de Responsabilidade Civil, cit., pp. 72-73); e TERESA ANCONA LOPEZ: “(...) para o direito civil, não havendo dano, não há indenização. Aliás, nem se pode falar em ilícito civil sem a existência de um prejuízo; é este elemento que dá conteúdo ao ato ilícito" ( $O$ Dano Estético: Responsabilidade Civil, $3^{\text {a }}$ ed., São Paulo, Revista dos Tribunais, 2004, p. 22).
} 
inicial e o patrimônio final do lesado ${ }^{250-251}$. Essa definição, contudo, passou a ser criticada por não incluir os chamados danos não patrimoniais, razão pela qual deu lugar à concepção de dano como lesão a um bem jurídico ${ }^{252}$, ou lesão a um interesse jurídico ${ }^{253}$, o que abrange tanto os danos patrimoniais como os danos não patrimoniais (ou morais).

Essa concepção ganhou força com a Constituição Federal de 1988 que assegura expressamente a indenização por dano moral (art. $5^{\circ}$, inciso $\mathrm{V}$ e X). No mesmo sentido, o Código Civil de 2002 faz expressa referência aos danos morais (artigo 186).

${ }^{250}$ CARLos Roberto GONÇAlves, Responsabilidade Civil, cit., p. 628.

${ }^{251}$ Escrevendo sobre a aplicação da concepção clássica de dano na jurisprudência brasileira, ANDERSON SCHREIBER esclarece que "essa identificação do dano jurídico com o dano natural (prejuízo) não se revelou tão problemática na fase inicial da responsabilidade civil brasileira, marcadamente patrimonialista, em que a quantificação do dano vinculava-se exclusivamente à teoria da diferença. De fato, sendo aferido por uma simples equação matemática entre o patrimônio da vítima anteriormente à lesão e o mesmo patrimônio no momento que lhe é posterior, o dano patrimonial equivale, substancialmente, ao sentido material ou vulgar de dano (dano como prejuízo). Em outras palavras, havendo decréscimo econômico, há dano em sentido patrimonial e sua ressarcibilidade somente fica excluída pela ausência dos demais pressupostos do ato ilícito, isto é, pela ausência de ilicitude da conduta ou de nexo causal entre a conduta e o dano" (Novos Paradigmas da Responsabilidade Civil..., cit., pp. 104-105).

${ }^{252}$ De acordo com AGostinHo AlviM, "o dano, em sentido amplo, vem a ser a lesão a qualquer bem jurídico, e aí se inclui o dano moral" (Da Inexecução das Obrigações e Suas Consequências, $3^{\mathrm{a}}$ ed., São Paulo, Editora Jurídica e Universitária, 1965, p. 187). No mesmo sentido, o entendimento de HANS ALBRECHT FISCHER: "É dano todo o prejuízo que o sujeito de direitos sofra através da violação dos seus bens jurídicos" (A Reparação dos Danos, tradução de António de Arruda Ferrer Correa, São Paulo, Saraiva, 1938, p. 7). Veja-se ainda a lição de CAIO MÁRIO DA SILVA PEREIRA: "Para a determinação da existência do dano, como elemento objetivo da responsabilidade civil, é indispensável assentar que houve ofensa a um 'bem jurídico' (...). Quando opto pela definição de dano como toda ofensa a um bem jurídico, tenho precisamente em vista fugir da restrição à patrimonialidade do prejuízo" (Responsabilidade Civil, $9^{\mathrm{a}}$ ed., Rio de Janeiro, Forense, 1999, p. 53). Sobre as diversas concepções de dano, vide: KARINE ANSILIERo ANGELIN, Dano Injusto como Pressuposto do Dever de Indenizar, Dissertação de Mestrado, Faculdade de Direito da Universidade de São Paulo, 2012.

${ }^{253}$ EDUARDO A. ZANNONI define o dano como a diminuição patrimonial ou não patrimonial que tenha por efeito a lesão a um interesse jurídico: "De lo expuesto, se infiere que, jurídicamente, el término 'daño' es apto para designar todo menoscabo patrimonial e, incluso, no patrimonial -como en el supuesto del daño moral" (...) "Pero, para que pueda decirse que existe un interés lesionado o agraviado, es menester que quien se disse damnificado demuestre que el menoscabo afecta, en su esfera propia, la satisfacción o goce de bienes jurídicos (en sentido lato) sobre los cuales él ejercía una facultad de actuar. Esta facultad de actuación en la esfera propia del damnificado constituye su interés; el daño ha lesionado ese interés" (El Daño en la Responsabilidad Civil, $3^{\mathrm{a}}$ ed., Buenos Aires, Astrea, 2005, pp. 49-51). Partindo da concepção de dano como violação a um interesse tutelado pelo ordenamento jurídico, ANDERSON SCHREIBER propõe a seguinte metodologia para aferição do dano ressarcível: “(...) a verificação do dano ressarcível resulta da constatação de violação à área de atuação legítima de um interesse merecedor de tutela. Tal área de atuação não pode ser delimitada em abstrato, mas exige sua concreta definição frente à conduta lesiva. Quando a conduta lesiva mostra-se, de pronto, antijurídica, a área de atuação do interesse lesado corresponde à sua área integral, cumprindo à vítima apenas demonstrar a efetiva afetação do interesse de que é titular, para que reste configurado o dano ressarcível. Quando a conduta lesiva não é, a princípio, antijurídica, mas autorizada pelo ordenamento em questão, cumpre ao magistrado estabelecer a relação de prevalência entre os dois interesses em conflito, definindo, à luz do dado normativo, as fronteiras entre a atuação legítima de cada qual nas circunstâncias do caso concreto. Violada esta relação de prevalência, há dano ressarcível" (Novos Paradigmas da Responsabilidade Civil..., cit., p. 189). 
Partindo da concepção de dano como lesão a um bem jurídico, ANTONIO JUNQUEIRA DE AZEVEDO propõe classificação que distingue entre, de um lado, o chamado dano-evento (violação a determinado bem jurídico) e, de outro lado, o chamado danoprejuízo (prejuízo patrimonial ou extrapatrimonial resultante da violação). Nas palavras do autor $^{254}$ :

\begin{abstract}
“(...) é preciso distinguir entre o dano-evento e o dano-prejuízo; o primeiro é a lesão a algum bem; o segundo, a consequência dessa lesão. Pode haver lesão à integridade física de uma pessoa e as principais consequências não serem de ordem pessoal, e sim patrimonial - por exemplo, se a vítima perdeu, total ou parcialmente, sua capacidade laborativa; ou, inversamente, a lesão pode ser a uma coisa, que está no patrimônio de alguém, e a consequência ser principalmente um prejuízo não patrimonial (dano moral) por exemplo, se o dono tinha, pela coisa, valor de afeição. O dano-evento é, pois, o dano imediato, enquanto o dano-prejuízo é o dano mediato."
\end{abstract}

Essa distinção é útil no estudo da responsabilidade civil por danos decorrentes da prática de cartel, pois nesses casos é comum que a lesão ao bem jurídico (dano-evento) e as consequências patrimoniais ou não-patrimoniais da lesão (dano prejuízo) ocorram em momentos distintos ${ }^{255}$.

Por exemplo, no caso de um contrato celebrado pelo Poder Público após licitação em que os participantes combinaram previamente os lances e os vencedores, o dano-evento ocorrerá por oportunidade da lesão à concorrência no certame licitatório. $\mathrm{O}$ dano-prejuízo, nesse caso, perdura por toda a vigência do contrato, na medida em que o Poder Público efetue o pagamento das parcelas com sobrepreço em razão do cartel.

As demandas envolvendo a prática de cartel constituem um excelente exemplo da importância fundamental do dano na disciplina da responsabilidade civil. Com efeito, a necessidade de demonstrar os danos concretos causados pela conduta é o principal traço distintivo entre, de um lado, a disciplina jurídica dos cartéis nas esferas administrativa e penal e, de outro lado, a responsabilidade na esfera civil.

\footnotetext{
${ }^{254}$ Estudos e Pareceres de Direito Privado, São Paulo, Saraiva, 2004, p. 291.

${ }^{255}$ Sobre a aplicação da classificação entre dano-evento e dano-prejuízo aos danos decorrentes da prática de cartel, ver também: Bruno OliveIRA MAGGi, O Cartel e Seus Efeitos no Âmbito da Responsabilidade Civil, cit., pp. 134-157.
} 
Nas esferas administrativa e penal, conforme analisado anteriormente, permite-se a punição dos infratores ainda que não haja prova de que a conduta tenha produzido efeitos anticompetitivos concretos, sendo suficiente a demonstração da mera potencialidade de produção de tais efeitos ${ }^{256}$. Diferentemente, a responsabilidade no âmbito civil exige a demonstração de que a prática produziu efeitos, causando dano aos prejudicados.

Essa importante diferenciação entre a tutela administrativa e civil da defesa da concorrência é esclarecida por ROBERTO AUGUSTO CASTELLANOS PFEIFFER ${ }^{257-258}$ :

"Há um aspecto importante que diferencia a tutela administrativa da tutela judicial da defesa da concorrência. Como ressaltado, para que ocorra uma infração contra a ordem econômica é imprescindível que a conduta tenha o potencial de produzir os efeitos mencionados nos quatro incisos do art. $20 \mathrm{da}$ Lei $\mathrm{n}^{\circ} 8.884$, de 1994, não sendo, porém, necessário demonstrar que ela produziu efeitos concretos. No entanto, ao contrário do que se dá na esfera administrativa, na ação de indenização é essencial demonstrar que a conduta produziu efeitos que causaram prejuízos aos consumidores, já que somente pode ser reparado um dano efetivamente sofrido. Assim, o pressuposto da indenização é a efetiva ocorrência do dano, o qual pode ser conceituado como uma diminuição ou subtração de um bem jurídico, tanto na esfera patrimonial como na moral".

A responsabilidade civil por danos decorrentes de infrações à ordem econômica se insere no fenômeno classificado por ANDERSON SCHREIBER como "expansão dos danos ressarcíveis", resultado do reconhecimento no direito contemporâneo de novos interesses objeto de tutela pelo ordenamento jurídico, cuja violação dá origem a novos danos objeto de reparação ${ }^{259-260}$. Nesse sentido, a consagração constitucional da proteção à

\footnotetext{
${ }^{256} \mathrm{Na}$ esfera administrativa, a redação do art. 36 da Lei 12.529/2011 dispõe expressamente que, para que se configure infração à ordem econômica, basta que as práticas "tenham por objeto ou possam produzir" determinados efeitos anticompetitivos, "independentemente de serem alçados". De igual modo, como visto o artigo $4^{\circ}$, inciso II da Lei 8.137/1990 não exige a produção concreta de efeitos para a caracterização do crime de cartel.

${ }^{257}$ Defesa da Concorrência e Bem-Estar do Consumidor, cit., p. 251.

${ }^{258}$ No mesmo sentido, LUIZ CARLOS BUCHAIN: "Sem a prova do dano sofrido pela vítima, o ato ilícito concorrencial permanece na esfera exclusiva do interesse da Administração Pública, competindo ao CADE enquanto órgão autárquico e judicante, investigar o ilícito e aplicar as penalidades administrativas previstas em lei, em defesa da ordem concorrencial pública. É a partir da prova do ato ilícito concorrencial e do efetivo prejuízo sofrido pela vítima, como consequência da conduta anticoncorrencial do agente, que o prejudicado poderá requerer judicialmente a cessação de prática anticoncorrenciais cumulativamente com as perdas e danos, independentemente da existência de processo administrativo no CADE" ( $O$ Poder Econômico e a Responsabilidade Civil Concorrencial, cit., p. 140).

259 "O primeiro prisma sob o qual a expansão do dano ressarcível costuma ser identificada é o quantitativo. (...) À parte essa expansão quantitativa, verifica-se, em todo mundo, e de modo ainda mais marcante, uma
} 
concorrência, aliada à maior efetividade da aplicação da legislação concorrencial, fez despertar nos últimos anos a consciência para a possibilidade e necessidade de ressarcimento dos danos decorrentes de cartéis e outras práticas anticompetitivas, os quais não eram objeto de reparação no passado.

Nos itens abaixo, a disciplina jurídica do dano será examinada à luz das especificidades da responsabilidade civil por danos decorrentes da prática de cartel, partindo-se da classificação entre danos patrimoniais (ou materiais) e danos não patrimoniais (ou morais) ${ }^{261}$.

\subsubsection{Danos patrimoniais (ou materiais)}

Na disciplina do Código Civil, os danos patrimoniais (ou materiais) objeto de reparação são o chamado dano emergente (efetiva diminuição patrimonial sofrida pela vítima) e o lucro cessante (aquilo que a vítima deixou de ganhar em virtude do ato ilícito) $)^{262-263}$.

expansão qualitativa, na medida em que novos interesses, sobretudo de natureza existencial e coletiva, passam a ser considerados pelos tribunais como merecedores de tutela, consubstanciando-se a sua violação em novos danos ressarcíveis" (Novos Paradigmas da Responsabilidade Civil..., cit., pp. 84-85).

${ }^{260} \mathrm{Na}$ doutrina estrangeira, GUIDO ALPA e MARIO BESSONI sustentam que "la funzione risarcitoria viene per così dire esaltata dall'incremento dei danni che è un connotato tipico della società moderna" (Atipicità dell'Illecito - Parte Prima: I Profili Dottrinali, $2^{\circ}$ ed., Milano, Dott. A. Giuffrè Editore, 1980, p. 4). Em sentido semelhante, GENEVIEVE VINEY e PATRICE JOURDAIN escrevem que "L'evolution a donc progressivement élargi la vocation indemnitaire de la responsabilité qui tend désormais à appréhender tout atteinte à un intérêt quelconque (Section 1), à condition qu'elle soit certaine. (...) La tendance extensive qui vient d'être signalée s'est manifestée non seulement à propos de la notion même de lésion d'un intérêt $(\S 1)$, mais aussi quant à la nature des intérêts lésés $(\S 2)$ et pour l'appréciation de leur légitimité $(\S 3)$ " (Traité de Droit Civil: Les Conditions de La Responsabilité, 3a ed., Paris, Librarie Generale de Droit e de Jurisprudence, 2006, p. 15).

${ }^{261}$ Sobre a classificação, RUI STOCO esclarece que "não se pode deixar de atentar para a grande divisão entre danos patrimoniais ou materiais e danos morais, imateriais ou não patrimoniais, cabendo lembrar (...) que a distinção entre dano patrimonial e dano moral só diz respeito aos efeitos, não à origem do dano, pois, neste aspecto, o dano é uno e indivisível" (Tratado de Responsabilidade Civil..., cit., p. 1232). HANS AlBRECHT FISCHER escreve: (...) o dano 'patrimonial' não é senão uma modalidade, um caso particular do conceito geral de 'dano', que em si abrange também as lesões causadas a outros bens jurídicos. A distinção entre danos patrimoniais e não patrimoniais - danos imateriais, dommage moral - reveste importância fundamental nas legislações modernas, pois - como se depreende da citada norma - a espécie e alcance da reparação variam segundo a natureza do dano causado" (A Reparação dos Danos, cit., p. 9). CARlos AlBerto BitTAR, por sua vez, sustenta que "permite essa classificação alcançar-se o âmago da composição da teoria do dano, dividindo-se este em material ou moral, consoante se manifeste no aspecto patrimonial (ou pecuniário) da esfera jurídica lesada" (Reparação Civil por Danos Morais, 3ª ed., São Paulo, Revista dos Tribunais, 1999, p. $35)$.

${ }^{262} \mathrm{O}$ art. 402 do Código Civil dispõe que "salvo as exceções expressamente previstas em lei, as perdas e danos devidas ao credor abrangem, além do que ele efetivamente perdeu, o que razoavelmente deixou de lucrar". 
No caso do cartel, o dano patrimonial (ou material) decorre do chamado sobrepreço, o qual foi examinado no capítulo 1 e consiste no preço mais elevado pago pelo adquirente dos produtos ou serviços em decorrência do aumento artificial dos preços causado pelo cartel $^{264}$. De acordo com TérCiO SAMPAIO FERRAZ JúNIOR, “o chamado sobrepreço, na ocorrência de conduta colusiva (cartel), é um referencial quantitativo para apurar o dano por abuso de poder econômico" ${ }^{\text {265-266. }}$.

\subsection{Prova e quantificação do sobrepreço}

No tocante à prova e quantificação do sobrepreço causado pelos cartéis, deve-se distinguir entre, de um lado, a prova da existência do dano e, de outro lado, a quantificação do dano ( "quantum debeatur"). No direito brasileiro, embora a quantificação do dano possa ser reservada para a fase de liquidação de sentença (CPC, art. $286^{267}$ e 475-

\footnotetext{
${ }^{263}$ Como ensina Clóvis Bevilaqua, "chamam-se perdas e danos ou perdas e interesses, os prejuízos ocorridos ao credor, tanto os que efetivamente lhe diminuem o patrimônio (damnum emergens), quanto os simplesmente previstos no momento de celebrar-se o contrato (lucrum cessans)" (Direito das Obrigações, $5^{\text {a }}$ ed., Rio de Janeiro, Freitas Bastos, 1940, p. 125). No caso específico dos danos em matéria concorrencial, ANDRÉ MARQUES FRANCISCO escreve que "a infração antitruste poderá dar ensejo a duas modalidades distintas de dano: o dano emergente (suportado de imediato pelo patrimônio da vítima) e o lucro cessante (redução da perspectiva razoável de lucros da vítima)" (Responsabilidade Civil por Infração da Ordem Econômica, cit., p. 81).

${ }^{264}$ Como discutido anteriormente, no caso do cartel de compra, diferentemente do cartel de venda, o prejuízo não decorre do sobrepreço, mas do preço artificialmente reduzido decorrente do acordo entre os membros do cartel. Considerando que a hipótese mais comum é o cartel de venda, as considerações sobre o dano feitas neste tópico terão por base o sobrepreço causado pelos cartéis. ANDRÉ MARQUES FRANCISCO fornece exemplo de dano sofrido nessa situação: "Basta observar, a título de exemplo, o caso do Cartel dos Frigoríficos, que não produziu diretamente efeitos à jusante, mas sim à montante; os frigoríficos impuseram a restrição aos produtores de gado, que sem ter como escoar sua produção por outras vias, tiveram de aceitar negociar seus produtos por um subpreço" (Responsabilidade Civil por Infração da Ordem Econômica, cit., p. $81)$.
}

265 "Direito da Concorrência e Enforcement Privado na Legislação Brasileira", cit., p. 23.

${ }^{266}$ Roberto Augusto CASTEllanos PfeifFer, por sua vez, escreve: "Pensemos no exemplo de um cartel. Além do prejuízo a toda a sociedade, decorrente do uso ineficiente dos recursos econômicos escassos, há a lesão a cada consumidor que pagou um sobrepreço pelo produto ou serviço objeto do cartel" (Defesa da Concorrência e Bem-Estar do Consumidor, cit., p. 253). No mesmo sentido, LUIZ CARLOS BuCHaIN: "A vítima paga o preço ilicitamente majorado por determinado bem (ou recebeu preço inferiorizado), devido à manipulação do mercado por determinados agentes como, por exemplo, preços excessivos cobrados por monopolistas ou por cartéis (...). Nesses casos, é a diferença entre o preço cobrado (ou o preço devido) e o efetivamente pago (ou recebido) que quantificará o dano sofrido" (O Poder Econômico e a Responsabilidade Civil Concorrencial, cit., pp. 171-172).

267 “Art. 286. O pedido deve ser certo ou determinado. É lícito, porém, formular pedido genérico: I - nas ações universais, se não puder o autor individuar na petição os bens demandados; II - quando não for possível determinar, de modo definitivo, as conseqüências do ato ou do fato ilícito; III - quando a determinação do valor da condenação depender de ato que deva ser praticado pelo réu". 
$\mathrm{A}^{268}$ ), o que pode ocorrer inclusive em demandas envolvendo responsabilidade civil por danos oriundos de práticas anticompetitivas ${ }^{269}$, é necessário que a existência do dano seja provada no curso do processo de conhecimento, sob pena de improcedência da ação ${ }^{270}$.

No caso dos cartéis, a prova da existência dos danos envolve: (i) em primeiro lugar, prova de que houve sobrepreço no mercado em decorrência do cartel (o que pode ser feito por diversos meios, como estudos econômicos contendo análise dos preços praticados ou mediante a prova de contatos entre os concorrentes nos quais eles diretamente ajustam os aumentos de preços, aliada à prova de que os preços ajustados foram praticados); e (ii) demonstração de que o autor adquiriu os produtos ou serviços das empresas cartelizadas no período e no mercado em que se verificou o sobrepreço.

Com relação à quantificação dos danos (“quantum debeatur”), trata-se de tarefa complexa, que envolve a comparação entre o preço pago pelo prejudicado e o preço que deveria ter sido pago em um cenário hipotético em que o cartel não existisse. Exatamente por conta dessas dificuldades, a quantificação dos danos costuma ser apontada como um dos maiores obstáculos à reparação dos prejuízos causados por cartéis ${ }^{271}$.

\footnotetext{
268 “Art. 475-A. Quando a sentença não determinar o valor devido, procede-se à sua liquidação”.

269 Roberto Augusto CASTEllanos PFEIFFER, escrevendo especificamente a respeito das ações civis públicas para reparação de danos, esclarece: “A sentença que julga procedente a ação coletiva apenas fixa a responsabilidade do réu pela reparação dos danos causados, sem indicar o montante a ser pago. Deste modo, é uma sentença ilíquida, porém certa, uma vez que estabelece o dever de indenizar. Nesse contexto, no curso da instrução probatória da ação coletiva o juiz irá inicialmente verificar se o réu efetivamente cometeu um ato ilícito, o que, na hipótese analisada, pressupõe a demonstração de que houve a prática de uma infração contra a ordem econômica, sendo, assim, a conduta dos réus passível de enquadramento no tipo do art. 20 da Lei ${ }^{\circ} 8.884$, de 1994. Posteriormente, o Juiz deverá averiguar se tal conduta gerou um dano e que há nexo de causalidade entre o dano apontado e a conduta ilícita (que, para as finalidades da presente tese é a prática de uma infração contra a ordem econômica). Entendendo que sim, prolatará uma sentença condenatória genérica, fixando a responsabilidade do réu pelos danos causados" (Defesa da Concorrência e Bem-Estar do Consumidor, cit., p. 261).

${ }^{270}$ A título de exemplo, os seguintes julgados do TJ/SP: "Se não se comprovam as perdas e danos durante a ação, não pode esta vingar. Só se apuram em execução quando evidenciados na ação" (TJSP, $5^{\text {a }}$ Câmara, Rel. Silva Costa, j. 30.05.1985, RJTJSP 97/225) e "Os danos hão de ficar provados na fase de conhecimento, sob pena de ser julgada improcedente a ação; somente a apuração do seu quantum é que pode ser relegada para a execução quando os elementos constantes dos autos não autorizam decisão a respeito de sua liquidez" (TJSP, $1^{\text {a }}$ Câmara, Rel. Andrade Junqueira, j. 13.12.1977, RT 512/113). Julgados mencionados em: RUI STOCO, Tratado de Responsabilidade Civil..., cit., pp. 1238-1239.

${ }^{271}$ Em estudo encomendado pela Comissão Europeia sobre a quantificação de danos decorrentes de práticas anticompetitivas, registra-se que "one of the obstacles to damages actions is the quantification of damages" (Oxera Consulting, Quantifying Antitrust Damages..., cit., p. 1).
} 
Nesse contexto, conforme analisado anteriormente, a conclusão a que se chegou no direito norte-americano e europeu é de que não se pode exigir grau de precisão excessivo no cálculo do sobrepreço decorrente do cartel, sob pena de inviabilizar a reparação dos danos. Admite-se, portanto, que, desde que haja prova da existência do cartel e de seus efeitos, a quantificação dos prejuízos seja feita por meio de estimativas.

No Brasil, ainda não há jurisprudência sobre a metodologia mais adequada para a quantificação dos prejuízos decorrentes de cartel. Os poucos precedentes em que houve decisão determinando o ressarcimento de danos materiais causados pelos cartéis não fornecem, até o momento, qualquer parâmetro com relação à quantificação dos danos. Vejam-se os critérios adotados nos seguintes casos:

i) na decisão proferida em processo envolvendo cartel entre revendedores de combustíveis no Município de Guaporé-RS, o cálculo dos prejuízos foi reservado para a fase de liquidação de sentença, não tendo sido explicitado o critério de cálculo a ser empregado ${ }^{272}$;

ii) no julgamento da ação civil pública envolvendo cartel na revenda de combustíveis do Município de Santa Maria-RS, novamente o cálculo dos danos foi reservado para liquidação de sentença, sem que a decisão tenha detalhado os critérios para quantificação do sobrepreço ${ }^{273}$;

iii) em outro caso, também do Rio Grande do Sul, dessa vez envolvendo revendedores de gás liquefeito de petróleo (“GLP”), a sentença condenatória, diante das dificuldades em calcular os prejuízos causados pelo alegado cartel, optou por

272 "Dano material (liquidação por arbitramento): A prova do dano material não decorre da aquisição do combustível pelo consumidor, mas do concerto do preço da gasolina, que implicou em prática abusiva para os consumidores locais. A aferição dos danos deve ocorrer em liquidação de sentença (...)" (TJ/RS, Apelação Cível no 70018714857, $3^{\text {a }}$ Câmara Cível, Rel. Paulo de Tarso Vieira Sanseverino, j. 12.07.2007).

273 “Diante do exposto, julgo parcialmente procedente a presente Ação Civil Pública para os efeitos de: (...) condenar os requeridos a reparar os consumidores pelo dano material decorrente do alinhamento de preços dos combustíveis no comércio local; O quantum indenizatório deverá ser apurado mediante liquidação de sentença, tendo como marco inicial a data da instauração do inquérito civil (02/08/2002 - fl. 31), prolongando-se até a data em que foi concedida a medida antecipatória, qual seja, 23/08/2004 (fl. 583-590). O valor a ser indenizado deverá ser dividido entre os estabelecimentos demandados, na proporção do faturamento bruto auferido pelos mesmos nos anos respectivos à apuração do prejuízo, sendo reconhecida a responsabilidade pessoal dos respectivos representantes legais que figuram no polo passivo, consoante fundamentação supra” (Ação Civil Pública no 027/1.05.0004158-2, Juíza de Direito Stefânia Frighetto Schneider, $14^{a}$ Vara Cível de Santa Maria-RS, Arlindo dos Santos Dutra e outros, j. 28.12.2010). 
arbitrar os prejuízos tomando como parâmetro o valor da causa, tomando como parâmetro o valor total de $\mathrm{R} \$ 1.000 .000,00$ (um milhão de reais), atualizado desde a propositura da ação e dividido entre as rés de acordo com sua participação de mercado $^{274}$; e

iv) em caso envolvendo a revenda de combustíveis em Pernambuco, o juiz da causa também arbitrou a indenização por perdas e danos em R \$ 1.000.000,00 (um milhão de reais $)^{275}$, sem detalhar os critérios para o cálculo; a indenização foi posteriormente reduzida em sede de apelação para $\mathrm{R} \$$ 500.000,00 (quinhentos mil reais), com fundamento nos princípios "da proporcionalidade e da razoabilidade, 276 .

\subsection{Principais métodos de quantificação do sobrepreço}

Considerando que a jurisprudência atual não fornece parâmetros seguros para a definição dos critérios para quantificação dos danos, a literatura econômica pode ser de grande auxílio, ao estabelecer determinados métodos por meio dos quais se pode razoavelmente calcular os prejuízos causados pelo cartel.

274 “Com relação ao quantum indenizatório, a sugestão dos autores, embora razoável - 'R $\$ 0,10$ (dez centavos de real) para cada botijão de gás (P2 + P13 + P45) comercializado no período (ano de 1991 a 1997) segundo dados do DNC, sendo cada ré condenada de acordo com sua participação no mercado na época, maiores lucros, maiores sanções' (fl. 37) - traria imensos percalços para execução, porque requer a coleta de dados documentais apurados na época por órgão governamental já extinto. São conhecidas as dificuldades enfrentadas para a guarda de documentos em casos de transição entre entes da Administração. Por outro lado, não é certo que as empresas tenham guardado tais informações. É previsível que a consulta não seria fácil, que haveria discussões longas, o que retardaria ainda mais a solução efetiva do processo. Destarte, tomo como parâmetro para a indenização o valor atribuído à causa, R\$ 1.000.000,00 (um milhão de reais), atualizado desde a propositura da ação (2 de outubro de 1997) pelos índices normalmente admitidos na Justiça Federal (UFIR e, a partir de $1^{\circ}$ de janeiro de 2001, IPCA-E). (...). Cada ré arcará com percentual da condenação equivalente à sua participação no mercado na época, conforme documentos dos autos (...). Incidirão ainda juros moratórios de $1 \%$ ao mês, a contar da publicação desta sentença, afastando-se a aplicação do enunciado da súmula 54 do STJ, em vista da particularidade do caso, em que os danos, pela sua fluidez e disseminação, houveram de ser arbitrados pelo juízo" (Ação Civil Pública no 97.00.21424-9-RS, Juíza Federal Paula Beck Bohn, Subseção de Porto Alegre - RS, j. 13.01.2010).

275 "Condeno ainda, o Sindicombustíveis e as sociedades comerciais relacionadas na inicial, solidariamente, ao pagamento de indenização por perdas e danos em favor do fundo de que trata o art. 13 da Lei n. $^{\text {o }}$ 7.347/1985 no montante de R\$ 1.000.000,00 (um milhão de reais)" (Ação Civil Pública n ${ }^{\circ}$ 001233456.1999.4.05.8300, 12ª Vara Federal de Pernambuco, Juíza Federal Ivana Mafra Marinho, j. 04.11.2009).

276 "Verifico que a importância de R\$ 1.000.000,00 (hum milhão de reais) arbitrada na origem atenta contra os primados da razoabilidade e da proporcionalidade, ainda que se leve em conta o alentado número de demandados, pelo que se torna prudente a sua redução para R \$ 500.000,00 (quinhentos mil reais)" (Tribunal Regional Federal da 5a Região, Apelação no 498545 - origem no 0012334-56.1999.4.05.8300, $3^{\mathrm{a}}$ Turma, Relator Des. Federal Luiz Alberto Gurgel de Faria, j. 22.11.2012). 
Nos parágrafos abaixo serão examinados os principais métodos apontados pela literatura econômica para a quantificação do sobrepreço causado pelos cartéis. O objetivo da análise não é esgotar o tema, mas apenas traçar um panorama dos principais métodos existentes, apontando suas principais vantagens e desvantagens, para que se possa, ao final, avaliar se a utilização desses métodos é compatível com o direito brasileiro.

Como visto acima, a quantificação do sobrepreço causado pelo cartel pressupõe necessariamente a comparação entre, de um lado, os preços praticados pelas firmas cartelizadas e, de outro lado, os preços que seriam vigentes em um cenário hipotético em que o cartel não tivesse ocorrido, o chamado cenário contrafactual ( "but-for scenario”). Assim, qualquer metodologia para quantificação de danos decorrentes do cartel pressupõe inicialmente a estimação, com base nas melhores informações disponíveis, do cenário contrafactual ${ }^{277}$, o qual servirá de base de comparação com o cenário cartelizado verificado na prática, para que então seja possível calcular o sobrepreço causado pelo cartel $^{278}$.

Em estudo específico sobre quantificação de danos causados por práticas anticompetitivas, a Comissão Europeia classifica as diferentes metodologias para quantificação de danos em três grupos, com base nos diferentes critérios empregados para a estimação do cenário contrafactual: (i) bases comparativas ("comparator-based approach"); (ii) análise financeira das firmas ("financial-analysis-based approach"); e (iii) adoção de hipóteses sobre estruturas de mercado ("market-structure-based approaches") ${ }^{279}$.

\footnotetext{
277 "The essential starting point for any damages quantification is the but-for premise that the defendant's violation did not occur. That premise is the foundation for constructing a hypothetical "but-for world", which, when compared to the plaintiff's actual experience, should isolate the effect of the violation on the plaintiff from the effects of all other events. A quantification of the difference between the plaintiff's experience in the but-for worlds determines the amount of damages" (American Bar Association, Proving Antitrust Damages..., cit., p. 53).

278 "The second stage [in damages calculation] is moving form the factual-counterfactual comparison to a final damages value" (GunNAR Niels, Helen Jenkins e James KAVANAGH, Economics for Competition Lawyers, cit., p. 500).

${ }^{279}$ Oxera Consulting, Quantifying Antitrust Damages..., cit., pp. 44-45. No presente trabalho, utiliza-se a denominação em português das metodologias tal como traduzida em GuSTAVO MADI REZENDE, SOLANGE Kielber e MARIa FernANDa CAPORALE MADI, "Métodos de Mensuração das Indenizações Privadas em casos de Cartel", in Revista do IBRAC, ano 18, vol. 20, 2011, pp. 411-425.
} 
Os métodos incluídos no primeiro grupo ("bases comparativas”) procuram utilizar dados de fontes que não foram afetadas pelo cartel para estimar o cenário contrafactual e compará-lo com o cenário de cartel verificado no caso concreto. As fontes de comparação são as seguintes:

i) Comparação entre os preços vigentes no mercado antes e depois do cartel. Embora o método seja mais conhecido como "antes e depois" ("before and after method"), na realidade são possíveis três tipos de comparação, a depender dos dados disponíveis: preços vigentes antes da prática cartelizada com aqueles vigentes durante o cartel ("before and during"), preços vigentes durante o cartel com aqueles praticados após o término da infração ( "during and after”) e, finalmente, a comparação entre os preços praticados antes, durante e depois do cartel ("before during and after" ${ }^{280}$. Trata-se de metodologia empregada há vários anos no direito norte-americano, conforme visto acima, que tem como principal vantagem permitir a comparação de informações relacionadas ao mesmo mercado em que a infração ocorreu, sem precisar recorrer a dados referentes a outros mercados. As principais desvantagens decorrem do fato de nem sempre ser possível definir com precisão o período em que o cartel ocorreu ou encontrar informações confiáveis sobre o comportamento do mercado antes do cartel $^{281}$; além disso, é necessário levar em conta possíveis mudanças no comportamento do mercado ao longo do tempo (e.g., crises econômicas, aumento da demanda, dentre outros) que não têm relação com o cartel e podem influenciar no comportamento dos preços, afetando o resultado da análise $\mathrm{e}^{282}$;

ii) Comparação entre os preços praticados no mercado cartelizado e aqueles vigentes em outros mercados, firmas ou países que não tenham sido afetados pelo cartel (o chamado método de comparação por "cross-section”, também conhecido como

\footnotetext{
${ }^{280}$ Oxera Consulting, Quantifying Antitrust Damages..., cit., p. 52.

281 “O período de atuação do cartel, por exemplo, nem sempre é uma informação precisa: ainda que seja um item sempre presente nas condenações administrativas, nem sempre há como ter certeza de que, na prática, o período indicado coincide com o real efeito do cartel. Essa imprecisão dificulta (no limite, inviabiliza) a aplicação dos métodos 'antes e depois"' (GuSTAVo MADI REZENDE, SOLANGE KIELBER e MARIA FERNANDA CAPORAlE MADI, "Métodos de Mensuração das Indenizações Privadas em casos de Cartel”, cit., p. 422).

282 "Because the before-during-after approach looks outside the damages period, changes over time in economic conditions, the plaintiff's circumstances, and a host of other variables must be examined" (American Bar Association, Proving Antitrust Damages..., cit., p. 58).
} 
"yardstick method" ou "benchmark method"). Essa metodologia também é bastante empregada no direito norte-americano e tem por principal vantagem prescindir de informações sobre o período de início e término do cartel, as quais nem sempre estão disponíveis. A principal desvantagem é o fato de o método se basear em informações relacionadas a mercados distintos daquele em que o cartel ocorreu, sendo necessário levar em conta as características específicas de cada mercado para que a comparação possa ser feita de maneira adequada ${ }^{283}$; e

iii) Cruzamento das comparações anteriores (por período e "cross-section”) de modo a examinar a evolução dos preços em mercados afetados e não afetados pelo cartel, antes, durante e depois da infração (o chamado “diference-in-diferences method”). A vantagem desse método é viabilizar o exame tanto das variações de preço no tempo como entre mercados distintos, o que reduz as possíveis imprecisões decorrentes da utilização isolada de apenas um dos métodos anteriores; no entanto, a utilização desse método depende da disponibilidade de um amplo conjunto de informações, o que frequentemente inviabiliza sua utilização na prática ${ }^{284}$.

Os métodos incluídos no segundo grupo (“análise financeira das firmas") procuram utilizar as informações financeiras das empresas com o objetivo de estimar o sobrepreço. Um dos métodos empregados é a comparação entre as margens de lucro auferidas pelas empresas cartelizadas com as margens auferidas por empresas em um cenário contrafactual em que o cartel não tivesse ocorrido. Considerando que o cartel é uma infração praticada com o objetivo de aumentar os lucros dos membros do cartel, tratase de comparação que permite estimar os ganhos obtidos pelos cartelistas e, desse modo, estimar o prejuízo causado pela infração.

Uma das vantagens dessa metodologia é a possibilidade de utilização de dados das próprias empresas, sem que seja necessário recorrer a modelos teóricos. No entanto, é imprescindível que as informações sobre margens, lucro, etc., das empresas estejam disponíveis para que seja possível fazer a comparação, o que nem sempre ocorrerá,

\footnotetext{
283 "Because the yardstick approach looks outside the affected market, and often even to firms other that the plaintiff, similar issues of comparability arise. Perfection is not required, and adjustments may be used to account for differences" (American Bar Association, Proving Antitrust Damages..., cit., p. 58).

${ }^{284}$ Oxera Consulting, Quantifying Antitrust Damages ..., cit., p. 61.
} 
em especial caso as empresas envolvidas não publiquem suas demonstrações financeiras ${ }^{285}$. Além disso, ao se utilizar o método de análise financeira das firmas, deve-se tomar o cuidado de levar em consideração outras variáveis que podem afetar os resultados da empresa (e.g., eventuais aumentos nos custos) e que não tenham relação com o cartel.

Finalmente, os métodos incluídos no terceiro grupo ("adoção de hipóteses sobre estruturas de mercado") procuram estimar o sobrepreço a partir de modelos teóricos das diferentes estruturas de mercado (concorrência perfeita, monopólio e oligopólio, dentre outras). Uma forma de se estimar o sobrepreço é adotar determinado modelo para o cenário contrafactual (e.g., concorrência perfeita) e estimar o sobrepreço a partir da comparação com o modelo adotado para o cenário de cartel $^{286}$.

Essa metodologia tem a vantagem de permitir estimar o sobrepreço nas situações em que as informações necessárias para utilização dos demais métodos discutidos acima (bases comparativas ou análise financeira) não estejam disponíveis. A desvantagem, contudo, é o fato de os modelos teóricos exigirem a adoção de determinadas premissas sobre os mercados envolvidos, as quais não necessariamente refletirão com precisão as verdadeiras características do mercado analisado, o que pode tornar a estimativa sujeita a críticas ${ }^{287}$.

\subsection{Compatibilidade dos métodos de quantificação do sobrepreço com o direito brasileiro}

O breve exame empreendido acima permite confirmar que não é possível medir com precisão absoluta o prejuízo decorrente do sobrepreço, uma vez que todos os métodos de cálculo, em maior ou menor extensão, dependem da adoção de determinadas

\footnotetext{
285 “As análises financeiras, por exemplo, dependem de informações contábeis da empresa, cuja disponibilidade depende da estrutura de governança da empresa e de seus interesses estratégicos, de modo que a viabilidade da análise fica condicionada à possibilidade de se utilizar esses dados. A vantagem desse método é que ele traz informações mais objetivas do que os modelos teóricos baseados em estruturas de mercado" (Gustavo Madi Rezende, Solange Kielber e Maria Fernanda CAPORALE Madi, "Métodos de Mensuração das Indenizações Privadas em casos de Cartel”, cit., p. 417).

${ }^{286}$ Oxera Consulting, Quantifying Antitrust Damages..., cit., pp. 76-86.

287 “Essa mensuração está sujeita a diversas críticas relativas à dificuldade de aproximação entre as características reais dos mercado e as estruturas de mercado concebidas teoricamente" (GUSTAVO MADI Rezende, Solange Kielber e MARia FERnAnda CAPORAle MAdi, "Métodos de Mensuração das Indenizações Privadas em casos de Cartel”, cit., p. 422).
} 
premissas para que seja possível estimar um cenário contrafactual hipotético e compará-lo com o cenário de cartel.

Essa característica dos métodos de quantificação do sobrepreço, contudo, não constitui óbice à sua adoção no direito brasileiro. A interpretação mais coerente com os objetivos da lei concorrencial é aquela que, a exemplo das soluções adotadas em outros países, permite a quantificação dos prejuízos de acordo com critérios razoáveis e acessíveis às partes. Desse modo, entende-se que os métodos discutidos acima poderão ser aplicados ao tratamento da matéria no Brasil.

Confirmando a compatibilidade dos métodos acima com o direito brasileiro, deve-se observar que a jurisprudência nacional em matéria de responsabilidade civil já admite que, em determinadas circunstâncias, o cálculo dos prejuízos seja feito mediante critérios de razoabilidade a serem apurados no caso concreto, sem necessidade de precisão absoluta, como ocorre, por exemplo, no caso da indenização por lucros cessantes. Como ensina CARLOS RoBerto GONÇALVES ${ }^{288}$ :

\footnotetext{
"em se tratando (...) de lucros cessantes, a razão e o bom senso - assinala Giorgi - 'nos dizem que os fatos, ordinariamente, são insuscetíveis de prova direta e rigorosa, sendo, igualmente, de ponderar-se que não é possível traçar regras claras, a não ser regras muito gerais, a este respeito, o que dá lugar ao arbítrio do juiz na apreciação dos casos"”
}

Além disso, em outras áreas do direito brasileiro também se admite o cálculo de valores com base em estimativas pautadas por um critério de razoabilidade caso, por exemplo, haja mais de um método de cálculo e/ou não haja possibilidade de apuração do valor exato - em situações que, embora não envolvam responsabilidade civil, igualmente acarretam consequências patrimoniais significativas aos envolvidos. Essa situação ocorre nas mais diferentes hipóteses, como por exemplo:

i) na apuração da prática de dumping (preço de exportação inferior ao preço no mercado interno) por produtores/exportadores de país em que não vigora economia de mercado (e.g., China), caso em que o valor deverá ser calculado com base (a) no preço de venda do produto similar em terceiro país, substituto, em que vigore

\footnotetext{
${ }^{288}$ Responsabilidade Civil, cit., p. 758.
} 
economia de mercado; (b) no valor construído do produto similar em um país substituto; (c) no preço de exportação do produto similar de um país substituto para outros países, exceto o Brasil; ou (d) em qualquer outro preço razoável, sempre que nenhuma das hipóteses anteriores seja viável e desde que devidamente justificado $^{289}$;

ii) na avaliação do valor de sociedades empresárias para fins de dissolução parcial ou exercício de direito de retirada; embora a lei e/ou os atos constitutivos das sociedades comumente prevejam critérios que devam nortear tais avaliações, os métodos de avaliação são variados e todos eles conferem certa margem de discricionariedade e subjetividade ao avaliador $^{290}$; e

iii) na fixação do preço de venda por terceiro nos termos do artigo 485 do Código Civil, a qual é vinculante para as partes contratantes e cujo preço, de acordo com a

${ }^{289}$ Artigo 15 do Decreto ${ }^{\circ}$ 8.058, de 26 de julho de 2013. O exemplo consta de: TÉrCiO SAMPAIO FERRAZ JÚNIOR, "Direito da Concorrência e Enforcement Privado na Legislação Brasileira", cit., p. 26.

${ }^{290}$ Ao discorrer sobre os métodos de avaliação de sociedades para fins de apuração dos haveres devidos ao sócio retirante, excluído ou falecido, PRISCILA M. P. CORRÊA DA FONSECA chama a atenção para a diversidade de metodologias e para a subjetividade conferida ao avaliador: "Reina muita controvérsia a respeito da forma de apuração do goodwill entre os valores que devam integrar a avaliação dos haveres devidos ao sócio retirante, excluído ou falecido. A dissenção reside não apenas na diversidade de critérios existentes para a elaboração de cálculos, como também na complexidade da mensuração, em determinados casos, do referido sobrevalor. (...) Há vários e diversificados métodos para a avaliação da sociedade. Com amparo no lucro verificado, são inúmeras as fórmulas sistematizadas pelos experts para o cálculo do goodwill. Aquela mais comumente empregada é a que se denomina Fluxo de Caixa Descontado e que se baseia nos fluxos de caixa gerados em um determinado número de anos anteriores à avaliação, os quais são projetados para o futuro, também ao longo de um certo período de tempo. (...) Ao valor acima apurado é aplicada uma taxa de desconto, denominada de custo de capital - 'constituída do custo de oportunidade de cada fonte de financiamento' - calculada segundo critérios estabelecidos consoante as peculiaridades de cada caso, inclusive e principalmente com o denominado risco do fluxo, ou seja, um índice relativo às variáveis mercadológicas e macroeconômicas. Ao valor final encontrado é aplicada uma taxa de juros, geralmente aquela refletida pelos índices oficiais. Uma vez aplicada essa taxa de desconto, obtém-se o valor presente dos fluxos futuros, isto é, um importe contemporâneo à avaliação e que se viesse a ser investido em títulos daquela natureza deveria gerar, naquele mesmo prazo em que os fluxos de caixa foram projetados, os lucros que, em princípio, deveria auferir a sociedade, naquele mesmo período. (...) É este o método mais frequentemente utilizado para avaliação do valor econômico de uma pessoa jurídica e, por conseguinte, para mensuração do valor correspondente ao fundo de comércio. No entanto, as perícias voltadas à apuração dos haveres decorrentes da extinção parcial do vínculo societário, dizem respeito evidentemente a sociedades de capital fechado, nas quais a medição da taxa de risco e do custo de capital é tarefa de grande complexidade e subjetividade porquanto o perito deve se valer de elementos concernentes ao grau de risco de sociedades que atuam no mesmo segmento ou ainda fazer relacionar o risco a variáveis contábeis da própria sociedade. (...) Por outro lado, como a mensuração do goodwill implica a projeção, para o futuro, de resultados pretéritos, a incerteza que a cerca é intuitiva e não seria exagero afirmar que, muitas vezes, tal fixação ficará na dependência de apreciação subjetiva do magistrado acerca das perspectivas inerentes à atividade empresária desenvolvida, isto é, o futuro da economia do país, concorrência, novas tecnologias, o nível de modernização e adequação tecnológica da empresa, taxas de juros vigente, recessão, retração do mercado, facilidades na obtenção de crédito, etc.” (Dissolução Parcial, Retirada e Exclusão de Sócio, $5^{\mathrm{a}}$ ed., São Paulo, Atlas, 2012, pp. 202-207). 
doutrina, somente pode ser repudiado em caso de má-fé ou erro manifesto que afete a razoabilidade do preço $^{291}$.

Nesse sentido, a exemplo do entendimento vigente quanto à apuração dos lucros cessantes e dos demais casos de apuração por critérios de razoabilidade previstos no ordenamento jurídico brasileiro, a jurisprudência nacional em matéria de cartel deve caminhar no sentido de admitir que a quantificação dos prejuízos seja feita com base em estimativas baseadas em estudos econômicos. Essa é a posição da doutrina concorrencial brasileira, que reconhece que, caso não se permita que o sobrepreço seja calculado com base em tais critérios, restará inviabilizada a reparação dos danos oriundos de $\operatorname{cartel}^{292}$.

${ }^{291}$ Veja-se a lição de CARLOS ROBERTO GONÇALVES, em comentário ao art. 485 do Código Civil de 2002: "Se as partes expressamente convencionarem submeter-se ao preço fixado por um terceiro que escolherem, implicitamente renunciam ao direito de impugnar o laudo que este apresentar. Não têm o direito de repudiar a sua estimativa, que se torna obrigatória. Todavia, o preço não poderá ser desarrazoado, contrário às legítimas expectativas dos contratantes ou em desacordo com as circunstâncias que devem ser levadas em conta. Embora a estimação feita pelo terceiro não possa ser reduzida, é ressalvado a qualquer dos contratantes o direito de demandar a nulidade do contrato por dolo. O terceiro escolhido de comum acordo pelas partes levará em conta, ao fixar o preço, o valor atual da coisa, que é contemporâneo da estimativa e não o da data da celebração da avença, salvo estipulação em contrário" (Direito Civil Brasileiro, vol. 3, $9^{\mathrm{a}}$ ed., São Paulo, Saraiva, 2012, pp. 222-223).

292 TÉRCIO SAMPAIO FERRAZ JÚNIOR cita como exemplo o tratamento da matéria no direito alemão: "Conforme a jurisprudência internacional, a matéria da efetivação de pretensões privadas ao ressarcimento de danos causados por exercício de cartel é regida pelo princípio da reparação integral [no Brasil, por exemplo, CCiv. 2002, art. 944], que assenta: por princípio, o dano deve ser integralmente indenizado. Ora, a prova do dano material (dano emergente, lucros cessantes, juros), por força da natureza dos casos de cartel (e de abuso de poder econômico em geral) exige, na prática, uma apuração com base em uma "análise hipotética". (p. 26). Em regra, essa hipótese é construída e demonstrada sobre pesquisas econômicas de dados de mercado e das transações realizadas. É com base nessas pesquisas, apuradas no enforcement público, que são quantificados os danos no enforcement privado. O que se pede então ao prejudicado individual é a demonstração da relação de dependência (insumo necessário) em face do fornecedor cartelizado (fornecedor necessário) e a quantificação das aquisições efetuadas no período (faturas). Assim, a Corte Suprema alemã (BGH) aceita e fala, com esse objetivo, de Vergleichsmarktkonzept (conceito de mercado comparativo), ou seja, para avaliar o dano ocorrido em um mercado relevante concorrencialmente falseado é preciso recorrer, se possível, à comparação com mercados relevantes sob regime de livre concorrência. O que parece, então, à Corte alemã um procedimento correto, pois se baseia em dados concretos de mercados existentes. Com isso não se exige uma certeza rigorosa na quantificação do dano, mas antes uma consideração aproximada e em média (Durchschnittsbetrachtung), pois, do contrário - e aí a base da presunção -, o atendimento a uma pretensão de indenização ficaria impossível" ("Direito da Concorrência e Enforcement Privado na Legislação Brasileira", cit., pp. 26-27). Sobre a questão do cálculo do valor dos prejuízos, BRUNO OLIVEIRA MAGGI pondera: "Além da dificuldade ínsita à definição do valor da indenização, presume-se que haverá alguma resistência dos magistrados à forma de sua apuração. Ao contrário dos processos convencionais, nos quais a liquidação da sentença parte de valores reais que servem como base para o cálculo do valor da condenação, a quantificação dos prejuízos gerados por infrações à ordem econômica, em especial os cartéis, partem de um valor obtido através de estimativas baseadas em teorias econômicas. Nesse sentido, acredita-se que, antes mesmo da fase de apuração dos valores, as partes terão que convencer o juiz de que os estudos econômicos são formas legítimas e as mais adequadas para quantificar os prejuízos nesses casos" ( $O$ Cartel e seus Efeitos no Âmbito da Responsabilidade Civil, cit., p. 186). LUIZ CARLOS BUCHAIN também defende a aplicação de diferentes métodos para o cálculo dos prejuízos, tais como a comparação de preços em períodos anteriores e posteriores, a comparação com preços vigentes em outros mercados, a comparação das taxas de lucratividade, dentre outros ( $O$ Poder Econômico e a Responsabilidade Civil Concorrencial, cit., pp. 180181). 
Qualquer que seja o método adotado, contudo, o cálculo do sobrepreço deve ser baseado em critérios objetivos, sendo imprescindível que haja sólida demonstração da razoabilidade das premissas adotadas, assegurando-se o contraditório.

\subsection{Considerações sobre a admissão da chamada "pass-on defense" no direito brasileiro}

Com relação ao dano, deve-se ainda examinar a admissibilidade no direito brasileiro da chamada "pass-on defense", ou seja, a alegação de que o adquirente direto dos produtos não teria direito à indenização por não ter arcado com os prejuízos decorrentes do cartel, tendo sido capaz de repassar o montante do sobrepreço aos seus próprios clientes.

Como estudado no capítulo 4, no direito federal norte-americano não se admite a "pass-on defense", de modo que o comprador direto em regra tem direito a ser ressarcido pela totalidade do sobrepreço (multiplicado por três), ainda que o tenha transferido ao consumidor. Trata-se de regra de inspiração pragmática, que visa a simplificar a instrução probatória das demandas indenizatórias e, desse modo, contribuir para a efetividade da política de repressão de cartéis.

No direito comunitário europeu, por outro lado, a Diretiva da União Europeia sobre o tema reconhece a admissibilidade da "pass-on defense", que, de resto, tem sido amplamente aceita pelos tribunais dos Estados Membros ${ }^{293}$, razão pela qual, caso fique demonstrado que houve transferência do sobrepreço ao consumidor final, o comprador direto não terá direito a ser ressarcido pela parcela da indenização que foi transferida.

No Brasil, há precedentes que, embora não tratem da hipótese de cartel, envolvem situações semelhantes: (i) em decisão envolvendo reajuste contratual abusivo, a “pass-on defense” foi rejeitada, em decisão confirmada pelo Tribunal de Justiça de São

293 "There is no consistent regulation of passing-on in the different Member States. However, the passing-on defense has been recognized widely in national courts" (BOJANA VRCEK, "Overview of Europe", in ALBERT A. FOER e JONATHAN W. CUNEO (org.), The International Handbook of Private Enforcement..., cit., p. 284). 
Paulo $^{294}$; e (ii) por outro lado, em matéria tributária, o Superior Tribunal de Justiça, com fundamento em regra específica do Código Tributário Nacional (art. $166^{295}$ ) já decidiu que o contribuinte somente tem direito a repetição de indébito de tributos indiretos caso comprove que o valor do tributo a ser restituído não foi transferido ao comprador ${ }^{296}$.

Especificamente em caso de cartel, há precedente do Tribunal de Justiça de São Paulo que abordou a "pass-on defense". O acórdão confirmou sentença de primeira instância que havia negado o pedido de indenização formulado por concessionária de veículos por alegados prejuízos sofridos em decorrência de suposto cartel de frete de veículos. Dentre outras razões, o acórdão mencionou a existência de evidências de que o sobrepreço teria sido repassado aos consumidores ${ }^{297}$.

Considerando o sistema de responsabilidade civil do direito brasileiro, que somente autoriza a concessão de indenização na medida e extensão em que houver dano (Código Civil, art. 944 ${ }^{298}$ ), sendo vedado, ademais, o enriquecimento sem causa (Código

\footnotetext{
294 "Tampouco se pode perdoar a abstração do contrato e da lei a pretexto de que a autora teria repassado o aumento de seus custos aos seus preços, ou de que teria se apropriado do crédito de ICMS correspondente ao sobrepreço ilícito. A prevalecer tal argumento, não caberia mais a invocação do Direito na regulação das relações econômicas, remetendo-se o agente econômico atingido pela violação da lei e do contrato à autodefesa na arena do mercado, como se as empresas consumidoras dos gases industriais, ou quaisquer outras empresas, tivessem plena condição de repassar a integralidade do aumento de seus custos aos preços de seus produtos" (Ação Ordinária $n^{\circ}$ 583.00.2004.039483-2, Juiz de Direito Luiz Fernando Cirilo, j. 07.08.2009; a decisão mantida pelo Tribunal de Justiça de São Paulo no âmbito Apelação Cível no 0039483 92.2004.8.26.0100, $31^{\text {a }}$ Câmara de Direito Privado, Rel. Adilson de Araújo, j. 02.08.2011).
}

295 “Art. 166. A restituição de tributos que comportem, por sua natureza, transferência do respectivo encargo financeiro somente será feita a quem prove haver assumido o referido encargo, ou, no caso de tê-lo transferido a terceiro, estar por este expressamente autorizado a recebê-la".

296 “Tributário. ICM. Fornecimento de alimentação em bares e restaurantes. Ação de repetição do indébito. Artigo 166 do Código Tributário Nacional. Súmula n. 7 do STJ. Tratando-se de imposto indireto, a sua restituição somente pode se dar quando comprovado, pelo contribuinte, que não transferiu o respectivo ônus ao comprador. Aplicação da Súmula n. 7, deste superior tribunal, que inadmite o reexame de prova em recurso especial. Não conhecimento do recurso" (REsp 26085/SP, Rel. Ministro Hélio Mosimann, Segunda Turma, julgado em 04.11.1992, DJ 23.11.1992, p. 21878).

297 “Não se pode deixar de considerar ainda que os prejuízos sustentados pela apelante em razão do elevado valor dos fretes não se apresentaram evidentes, não se configurando desarrazoada a hipótese de tê-los repassado ao consumidor, consoante bem exposto na respeitável sentença impugnada (fls. 718). Com efeito, porque reduzida a margem de lucro, em razão da elevação do custo final do produto, tudo indica que foram os consumidores que arcaram com o aumento do preço" (TJSP, Apelação no 0149141-75.2009.8.26.0100, $4^{\text {a }}$ Câmara de Direito Privado, Relator Des. Milton Carvalho, julgado em 25.10.2012).

298 “Art. 944. A indenização mede-se pela extensão do dano”. 
Civil, art. $884^{299}$ ), conclui-se pela admissibilidade da chamada "pass-on defense" no direito brasileiro ${ }^{300}$.

Desse modo, caso seja comprovado que o comprador não arcou com a totalidade dos prejuízos decorrentes do cartel, por ter sido capaz de repassar parcela do sobrepreço aos consumidores dos seus próprios produtos, o valor de indenização deverá ser reduzido na medida do repasse do sobrepreço. Caso a totalidade do sobrepreço tenha sido repassada, o comprador direto não fará jus a qualquer indenização por danos materiais ${ }^{301}$, a menos que comprove haver sofrido lucros cessantes, conforme será discutido abaixo.

Em princípio, o ônus de provar que houve repasse é do réu, com base no art. 333, inciso III do CPC, que impõe ao réu o ônus de provar a "existência de fato impeditivo, modificativo ou extintivo do direito do autor" ${ }^{\prime 302}$. Não se justifica eventual posição de que caberia ao autor provar desde logo que não houve repasse, pois tal entendimento equivaleria a impor ao autor o ônus de provar fato negativo, o que inviabilizaria o ressarcimento na maioria dos casos. Nesse sentido, TÉRCIO SAMPAIO FERRAZ JúNIOR sustenta o seguinte ${ }^{303}$ :

"diante da prova de violação da lei concorrencial, o efeito prejudicial aos concorrentes (linha horizontal) e adquirentes diretos (linha vertical) é presunção implícita no mandamento legal. Por conta disso, em face da alegação pelo réu de repasse pelo autor, cabe ao réu o ônus da prova do repasse, jamais cabendo ao autor a prova negativa de que não repassou".

\footnotetext{
299 "Art. 884. Aquele que, sem justa causa, se enriquecer à custa de outrem, será obrigado a restituir o indevidamente auferido, feita a atualização dos valores monetários".

${ }^{300}$ ANDRÉ MARQUES FRANCISCO sustenta que "permitir que o comprador direto, que repassou o sobrepreço pago aos compradores indiretos, receba indenização no valor integral do sobrepreço caracterizaria manifesto enriquecimento sem causa" (Responsabilidade Civil por Infração da Ordem Econômica, cit., p. 96). No mesmo sentido: "Brazilian law allows pass-on defences by the offender (i.e., the allegation that the plaintiff passed on its losses to third parties or end-consumers)" (CARLOS FRANCISCO DE MAGALHÃES, GABRIEL NOGUEIRA DiAs e CRISTIANo RodRIGo DEL DEBBIO, "Brazil”, cit., p. 29).

${ }^{301}$ Nesse sentido, LuIZ CARLOS BUCHAIN escreve o seguinte: "Poderá ocorrer, entretanto, que o abuso de preços não tenha provocado a diminuição da venda da mercadoria ao longo da cadeia produtiva até o consumidor final, sendo o "abuso" de preço suportado e absorvido pelo consumidor final. Nesta hipótese, não haverá danos a serem indenizados, pois não houve prejuízo" (O Poder Econômico e a Responsabilidade Civil Concorrencial, cit., p. 174).

302 No mesmo sentido, ANDRÉ MARQUES FRANCISCO sustenta que cabe "ao infrator, evidentemente, comprovar a ocorrência do repasse" (Responsabilidade Civil por Infração da Ordem Econômica, cit., p. 96).

303 "Direito da Concorrência e Enforcement Privado na Legislação Brasileira", cit., p. 29.
} 
No entanto, caso o réu consiga demonstrar que os documentos necessários para a demonstração do "pass-on" estão exclusivamente na posse do autor, é razoável que o réu possa exigir que o autor exiba tais documentos nos autos, sob pena de serem havidos por verdadeiros os fatos que, por meio do documento, o réu pretendia provar, nos termos dos artigos 355 a 363 do $\mathrm{CPC}^{304}$.

Como visto acima, é exatamente esse o tratamento da matéria no direito europeu: o artigo 13 da Diretiva da União Europeia sobre o assunto prevê que o ônus de provar o repasse é do réu, o qual, contudo, tem direito de solicitar a apresentação de informações necessárias para demonstração do "pass-on" que estejam em posse do autor ou de terceiros.

\subsection{Possibilidade de cumulação de indenização por danos emergentes e lucros cessantes decorrentes do cartel}

O prejuízo decorrente do sobrepreço, na maioria dos casos, é caracterizado como dano emergente, uma vez que a vítima do cartel sofre diminuição patrimonial causada pelo preço pago, o qual foi artificialmente elevado em razão do cartel.

Em determinadas situações, contudo, o sobrepreço poderá dar origem a lucros cessantes. Com efeito, mesmo que consiga repassar parte ou todo o sobrepreço aos consumidores dos seus próprios produtos (a questão do "pass-on", discutida acima), o adquirente dos produtos ou serviços a preços cartelizados ainda assim poderá fazer jus à indenização caso fique comprovado que sofreu lucros cessantes como resultado do cartel.

Isso ocorrerá caso se verifique a seguinte hipótese: (i) por ser obrigado a adquirir insumos mais caros em virtude do cartel, o comprador direto promove aumento nos preços dos seus próprios produtos ou serviços, de modo a repassar parcela do sobrepreço aos seus próprios clientes (o "pass-on”); e (ii) como consequência do aumento de preços, as vendas dos produtos ou serviços ofertados pelo comprador direto sofrem

\footnotetext{
${ }^{304}$ Os artigos 355 a 364 do CPC dispõem sobre a exibição de documento ou coisa no curso do processo, havendo previsão de que, caso o requerido não exiba o documento ou caso sua recusa seja tida por ilegítima, “o juiz admitirá como verdadeiros os fatos que, por meio do documento ou da coisa, a parte pretendia provar" (art. 359).
} 
redução, ocasionando-lhe prejuízos na forma de lucros cessantes (naturalmente a redução dos lucros deverá ser demonstrada) ${ }^{305}$. Nessa hipótese, o comprador direto estará autorizado a ajuizar demanda pleiteando o ressarcimento pelos lucros cessantes ocasionados pelo cartel ${ }^{306}$.

Em determinados casos, ambas as formas de prejuízo podem se verificar: o comprador absorve parcela do sobrepreço (fazendo jus à indenização pelos danos emergentes incorridos) e, ao transferir a outra parcela do sobrepreço ao preço dos seus próprios produtos, sofre redução nas vendas, fazendo jus a indenização caso se demonstre a existência de lucros cessantes. Nesse sentido, TÉRCIO SAMPAIO FERRAZ JÚNIOR esclarece que "o dano é configurado pela soma do sobrepreço, menos o preço que seria pago sem a colusão e mais o efeito de eventuais perdas de vendas"307-308.

Não há "bis in idem" na cumulação de indenização por danos emergentes e lucros cessantes oriundos do sobrepreço, desde que fique demonstrado que: (i) o comprador absorveu parcela do sobrepreço decorrente do cartel (a parcela do sobrepreço que foi passada adiante deverá naturalmente ser excluída do cálculo do dano emergente); e (ii) o aumento no preço dos produtos em decorrência no aumento dos insumos adquiridos a preços cartelizados gerou redução nas vendas e resultou em lucros cessantes.

\footnotetext{
${ }^{305}$ HERBERT HOVEMKAMP, examinando a hipótese acima, ensina que "the reduction in output produces lost profits to firms, while the increase in price represents that part of the overcharge that is passed on to consumers" (Federal Antitrust Policy..., cit., p. 617).

306 LUIZ CARLOS BUCHAIN dá o seguinte exemplo: "Se, por exemplo, a empresa autora do pedido indenizatório se dedica ao varejo de produtos e eleva seus preços como resposta a uma ilegal e anterior elevação de preços praticada pelo atacadista ou pela indústria, poderá ter legitimidade e direito a requerer perdas e danos pela diminuição de vendas" (O Poder Econômico e a Responsabilidade Civil Concorrencial, cit., p. 173).

307 "Direito da Concorrência e Enforcement Privado na Legislação Brasileira", cit., pp. 23-24.

${ }^{308}$ Sobre o assunto, ANDRÉ MARQUES FRANCISCO esclarece: “Tem-se, portanto, que a vítima direta, ao pagar pelo sobrepreço, e dar continuidade à cadeia produtiva repassando seus produtos ao agente à jusante, terá três possibilidades distintas: (i) repassar integralmente o sobrepreço, comprometendo com isso sua demanda; (ii) absorver o sobrepreço sacrificando sua própria margem de lucro; ou ainda (iii) repassar apenas parcialmente o sobrepreço, reduzindo em menor escala sua margem de lucro e também sua demanda. (...) Assim que: (i) no primeiro caso, de repasse integral do sobrepreço, a vítima direta não terá como postular danos emergentes, na medida em que estes foram integralmente repassados, cabendo-lhe apenas, se o caso (será preciso, por evidente, demonstrar a redução da demanda, postular a indenização pelos lucros cessantes em razão da redução de sua demanda; (ii) no segundo caso, com a absorção integral, a tendência natural é que não haja alteração na demanda pelo produto/serviço (em razão da manutenção do preço), pelo que não seria cabível o pedido de lucros cessantes, mas apenas a reparação dos danos emergentes causados; e (iii) no terceiro caso, de repasse parcial, ambas as modalidades de danos poderiam se fazer presentes, eis que a alteração dos preços poderá resultar em redução de demanda, e que houve ainda aumento injustificado do custo não repassado" (Responsabilidade Civil por Infração da Ordem Econômica, cit., pp. 101-102).
} 
Para encerrar o tópico sobre os danos materiais decorrentes da prática de cartel, deve-se registrar que, no quadro atual do direito brasileiro, não há possibilidade de aplicação de um fator multiplicador da indenização por danos materiais como medida de desestímulo, a exemplo da condenação pelo triplo dos prejuízos ("treble damages") do direito norte-americano ${ }^{309}$.

Essa conclusão decorre do artigo 944 o Código Civil, que prevê que "a indenização mede-se pela extensão do dano". A regra específica prevista no art. 47 da Lei 12.529/2011 tampouco autoriza conclusão em sentido diverso, na medida em que somente há menção ao "recebimento de perdas e danos sofridos", sem qualquer referência à possibilidade de elevação da verba indenizatória como medida punitiva ou preventiva.

Nesse aspecto, note-se que, mesmo os autores que são favoráveis à introdução no direito brasileiro de indenizações com caráter punitivo e dissuasório (os chamados "punitive damages”, mencionados no capítulo 4), reconhecem que sua aplicação dependeria de lei expressa regulando a matéria ${ }^{310}$.

\footnotetext{
${ }^{309}$ ANDRÉ MARQUES FRANCISCO sustenta que "ao contrário do que ocorre nos Estados Unidos - e discutiu-se no âmbito da União Europeia -, aqui a indenização levará em consideração apenas o valor do efetivo prejuízo suportado pela vítima da infração, sem a adição de qualquer multiplicador; a indenização é tratada primordialmente como meio de reparar o dano sofrido pela vítima, e não como instrumento de punição do infrator (esse efeito, aqui, será meramente acidental - uma externalidade positiva da ação antitruste privada, como já se disse nos capítulos iniciais)" (Responsabilidade Civil por Infração da Ordem Econômica, cit., p. $83)$.

${ }^{310}$ Nesse sentido, defendendo a adoção de "punitives damages" no direito brasileiro e, ao mesmo tempo, reconhecendo a necessidade de lei específica, vejam-se as posições de DANIEL DE ANDRADE LEVY: "Compartilhamos da inquietação tantas vezes externada por doutrinadores como Maria Celina Bodin de Moraes, para quem somente se poderá atribuir caráter punitivo a hipóteses taxativamente previstas em lei, sendo indispensável que o legislador possa guiar o magistrado nessa missão, sob pena de se entregar ao julgador, nos dizeres de Carval, um verdadeiro "cheque em branco"” (Responsabilidade Civil: De um Direito dos Danos a um Direito das Condutas Lesivas, São Paulo, Atlas, 2012); PEDro RiCARdo e SerPa: "De tudo o quanto já se expôs, vê-se que, quer em razão do princípio constitucional da reserva legal (princípio da legalidade), quer em razão da função indenitária do princípio da reparação integral, quer, ainda, em razão da vedação ao enriquecimento sem causa, é inadmissível a utilização da indenização punitiva sem a prévia cominação legal. Este é, portanto, o pressuposto essencial para a introdução de tal sanção punitiva em nosso ordenamento, sem o qual o recurso à pena privada (quer por meio da imposição de uma quantia adicional à indenização compensatória, com fins punitivos e dissuasórios, quer, ainda, pela quantificação da indenização compensatória com fundamento em critérios alheios à quantificação do prejuízo) será ilegal e, em última instância, inconstitucional" (Indenização Punitiva, Dissertação de Mestrado, Faculdade de Direito da Universidade de São Paulo, 2011, p. 236); e NELSON RosenVALD: “Como consectário lógico de todo o exposto, somos peremptórios no sentido de que só haverá pena civil aquiliana no Brasil com reconhecimento
} 
Como se verá no tópico seguinte, contudo, com relação aos danos morais, diferentemente do que ocorre com relação aos danos materiais, a doutrina e a jurisprudência têm admitido que a fixação da indenização possa levar em conta critérios como a punição do ofensor e o desestímulo ao cometimento do novas infrações.

De resto, esse tema também será novamente abordado no capítulo 6, em que serão discutidas propostas de reforma do ordenamento jurídico brasileiro com relação à responsabilidade civil por danos decorrentes de cartel, avaliando-se a conveniência de introdução de um fator multiplicador inspirado nos "treble damages" norte-americanos.

\subsubsection{Danos morais}

\subsection{Reparação dos danos morais no direito brasileiro}

A reparação dos danos morais é garantida pelo artigo $5^{\circ}$, incisos $\mathrm{V}^{311}$ e $\mathrm{X}^{312}$ da Constituição Federal de 1988. Embora a indenização por dano moral já fosse admitida anteriormente pelos tribunais brasileiros - que paulatinamente afastaram as objeções que anteriormente se colocavam quanto ao tema ${ }^{313}$ - a reparação do dano moral somente ganhou projeção após sua positivação no texto constitucional ${ }^{314}$.

pelo legislador em norma específica" (As Funções da Responsabilidade Civil: A Reparação e a Pena Civil, São Paulo, Atlas, 2013, p. 204).

311 “Art. $5^{\circ}$. (...) V - é assegurado o direito de resposta, proporcional ao agravo, além da indenização por dano material, moral ou à imagem;”.

312 “Art. $5^{\circ}$. (...) X - são invioláveis a intimidade, a vida privada, a honra e a imagem das pessoas, assegurado o direito a indenização pelo dano material ou moral decorrente de sua violação;”.

313 SILVIO RODRIGUES elenca as diversas objeções que já se colocaram no campo doutrinário e jurisprudencial: "Muitas são as objeções levantadas contra a reparação do dano moral, a partir daquela que reputa imoral, se não escandaloso, discutir-se em juízo os sentimentos mais íntimos, bem como a dor experimentada por uma pessoa e derivada de ato ilícito praticado por outra. Dentre essas objeções é mister destacar as mais importantes, a saber: a) a falta do efeito durável do dano meramente moral; b) a dificuldade em descobrir-se a existência do dano; c) a indeterminação do número de pessoas lesadas; d) a impossibilidade de uma rigorosa avaliação em dinheiro da extensão do dano moral; e) o ilimitado poder que se tem de conceder ao juiz para avaliar o montante compensador do dano meramente moral. As objeções acima formuladas têm sido reiteradamente respondidas no campo doutrinário" (Direito Civil Responsabilidade Civil, cit., p. 190).

${ }^{314}$ Silvio de Salvo Venosa, Direito Civil-Responsabilidade Civil, cit., p. 49. 
O artigo 186 do Código Civil de 2002 veio a confirmar a possibilidade de reparação do dano moral no ordenamento jurídico brasileiro, dispondo que "aquele que, por ação ou omissão voluntária, negligência ou imprudência, violar direito e causar dano a outrem, ainda que exclusivamente moral, comete ato ilícito"315.

Não há unanimidade na doutrina e jurisprudência com relação ao conceito de dano moral. Na jurisprudência brasileira, o dano moral é comumente definido sob o aspecto subjetivo, sendo associado à dor, humilhação, angústia e sofrimento experimentados pela vítima. Essa concepção é criticada por enfocar apenas as eventuais consequências do dano, e não o dano em si, que, como visto acima, é modernamente definido como a lesão a um bem ou interesse juridicamente protegido ${ }^{316}$.

Nesse sentido, parcela da doutrina, ao conceituar o dano moral, enfatiza justamente a natureza do bem ou interesse jurídico lesado, definindo o dano moral como o dano que resulta de uma violação aos direitos da personalidade e afeta a esfera de valores da pessoa $^{317-318}$.

\footnotetext{
${ }^{315}$ RUI STOCO critica "o anacronismo do Código Civil perante a Constituição Federal": "O fato de o Código Civil de 2002 ter-se originado de um anteprojeto antigo (...) criou um descompasso entre ele, na parte em evidência, com a Constituição Federal de 1988, muito mais recente e que mudou o panorama jurídico em nosso País. Tanto isso é certo que o art. 186, viga mestra e ponto fulcral da responsabilidade civil, limitou-se a fazer menção ao dano moral, apenas en passant, fruto de inclusão posterior pela própria Comissão, na redação final do preceito. (...) Deixou, contudo, de disciplinar o dano moral, seus princípios e consequências da violação dos chamados direitos da personalidade" (Tratado de Responsabilidade Civil..., cit., p. 1685).
}

316 ANDERSON SCHREIBER critica essa concepção do dano moral: “Quando se propõem a selecionar os danos morais ressarcíveis, as cortes empregam critérios equivocados como a prova da 'dor, vexame, sofrimento ou humilhação - consequências eventuais e subjetivas do dano, que nada dizem com a sua ontologia; ou ainda a gravidade da ofensa - critério que, consagrado sob a fórmula de que 'o mero dissabor não pode ser alçado ao patamar do dano moral', implica verdadeira inversão na axiologia constitucional, já que semelhante condição não se impõe em âmbito patrimonial, onde qualquer prejuízo, por menor que seja, suscita reparação" (Novos Paradigmas da Responsabilidade Civil..., cit., p. 6). No mesmo sentido, veja-se a crítica de CARLOS ROBERTO GONÇALVES: "O dano moral não é a dor, a angústia, o desgosto, a aflição espiritual, a humilhação, o complexo que sofre a vítima do evento danoso, pois esses estados de espírito constituem o conteúdo, ou melhor, a consequência do dano. (...) O direito não repara qualquer padecimento, dor ou aflição, mas aqueles que forem decorrentes da privação de um bem jurídico sobre o qual a vítima teria interesse reconhecido juridicamente" (Responsabilidade Civil, cit., p. 650).

${ }^{317}$ Vejam-se a respeito, as definições de YUSSEF SAID CAHALI: "Parece mais razoável, assim, caracterizar o dano moral pelos seus próprios elementos; portanto 'como a privação ou diminuição daqueles bens que têm um valor precípuo na vida do homem e que são a paz, a tranquilidade de espírito, a liberdade individual, a integridade individual, a integridade física, a honra e os demais sagrados afetos'; classificando-se, desse modo, em dano que afeta a 'parte social do patrimônio moral' (honra, reputação, etc.) e dano que molesta a 'parte afetiva do patrimônio moral' (dor, tristeza, saudade etc.); (...). Na realidade, multifacetário o ser anímico, tudo aquilo que molesta gravemente a alma humana, ferindo-lhe gravemente os valores fundamentais inerentes à sua personalidade ou reconhecidos pela sociedade em que está integrado, qualificase, em linha de princípio, como dano moral" (Dano Moral, $2^{\mathrm{a}}$ ed., São Paulo, Revista dos Tribunais, 2000 , p. 20); CARlos AlBerto BitTAR: “(...) como categoria jurídica específica, danos morais são aqueles 
No entanto, o conceito de dano moral que prevalece na doutrina atualmente é aquele que enfatiza o seu aspecto extrapatrimonial, definindo-se o dano moral por exclusão $^{319}$, como sendo a lesão a um interesse jurídico tutelado que não acarreta consequências patrimoniais ${ }^{320}$.

suportados na esfera de valores da moralidade pessoal ou social, e, como tais, reparáveis em sua integralidade, no âmbito jurídico (Reparação Civil por Danos Morais, cit., pp. 43-44); RUI STOCO: “(...) em sede de necessária simplificação, o que se convencionou chamar de 'dano moral' é a violação da personalidade da pessoa, como direito fundamental protegido, em seus vários aspectos ou categorias, como a intimidade e a privacidade, a honra, a imagem, o nome e outros, causando dor, tristeza, aflição, angústia, sofrimento, humilhação e outros sentimentos internos ou anímicos" (Tratado de Responsabilidade Civil..., cit., p. 1683); e Silvio SALvo VenOSA: "Dano moral é o prejuízo que afeta o ânimo psíquico, moral e intelectual da vítima. Sua atuação é dentro dos direitos da personalidade" (Direito Civil - Responsabilidade Civil, cit., p. 49).

${ }^{318}$ Criticando a concepção de dano moral como lesão a um direito da personalidade, MARIA CELINA BODIN DE MORAES, propõe classificação sob a ótica civil-constitucional, definindo o dano moral como ofensa à dignidade humana: "Quanto à conceituação do dano moral: 1. Constitui dano moral a lesão a qualquer dos aspectos componentes da dignidade humana - dignidade esta que se encontra fundada em quatro substratos e, portanto, corporificada no conjunto dos princípios da igualdade, da integridade psicofísica, da liberdade e da solidariedade. 2. Circunstâncias que atinjam a pessoa em sua condição humana, que neguem esta sua qualidade, serão automaticamente consideradas violadoras de sua personalidade e, se concretizadas, causadoras de dano moral a ser reparado. 3. Não será, portanto, o sofrimento humano ou a situação de tristeza, constrangimento, perturbação, angústia ou transtorno, que ensejará a reparação, mas apenas aquelas situações graves o suficiente para afetarem a dignidade humana pela violação de um ou mais dentre os substratos referidos". 4. Para que se configure dano moral, não é preciso que se configure lesão a algum direito subjetivo da pessoa da vítima, ou a verificação de um prejuízo por ela sofrido. A violação de qualquer situação jurídica subjetiva extrapatrimonial em que esteja envolvida a vítima, desde que merecedora de tutela jurídica, será suficiente para gerar a reparação" (Danos à Pessoa Humana: Uma Leitura Civil-Constitucional dos Danos Morais, Rio de Janeiro, Renovar, 2003, p. 237).

${ }^{319}$ A definição do dano moral por exclusão também é objeto de críticas na doutrina. ANDERSON SCHREIBER considera tal definição demasiadamente ampla, sustentando que "defini-lo [o dano moral] por via negativa, como todo prejuízo economicamente incalculável, acaba por converter o dano moral em figura receptora de todos os anseios, dotada de uma vastidão tecnicamente insustentável. A definição do dano como um interesse tutelado, muito ao contrário, estimula a investigação sobre o objeto da lesão - o interesse da vítima efetivamente violado pelo ofensor -, a fim de se aferir o seu merecimento de tutela ou não, possibilitando a seleção dos danos ressarcíveis. A melhor doutrina brasileira tem defendido abertamente esse caminho" (Novos Paradigmas da Responsabilidade Civil..., cit., p. 109). ANTONIO JeOVÁ SANTOS, por sua vez, sustenta que "afirmar que dano moral é lesão não patrimonial é nada definir. Princípio decorrente da boa lógica, indica que não se define, introduzindo um conceito negativo no objeto definido" (Dano Moral Indenizável, $4^{\mathrm{a}}$ ed., São Paulo, Revista dos Tribunais, 2003, p. 92).

${ }^{320}$ Vejam-se as definições de EDUARDO A. ZANNONI: "denomínase 'daño moral' -o agravio moral- al menoscabo o lesión a intereses no patrimoniales provocado por el evento dañoso, es decir, por el hecho o acto antijurídico. De acuerdo con lo explicado al ocuparnos del concepto de daño (§ 21), la noción se desarrolla sobre la base de los siguientes presupuestos: la naturaleza del interés lesionado y la extrapatrimonialidad del bien jurídico afectado" (El Daño en la Responsabilidad Civil, cit., p. 149); PATRICE JOURDAIN: "C'est celui qui, ne portant pas atteinte au patrimoine, n'a pas d'incidence économique directe e n'est donc pas immediatement susceptible d'évaluation pecuniaíare" (Les Principes de La Responsabilité Civile, $5^{\mathrm{e}}$ ed., Paris, Dalloz, 2000, p. 138); RENÉ SAVATIER: "Nous entendons par dommage moral toute souffrance humaine ne résultant pas d'une perte pécuniaiere" (Traité de La Responsabilité Civil: En Droit Français, Tome II, $10^{\mathrm{e}}$ ed., Paris, Librarie Génerale de Droit et de Jurisprudence, 1951, p. 92); ANTONIO JUNQUEIRA DE AZEVEDO: "o dano moral, por sua vez, é, na verdade, o não-patrimonial; deve ser conceituado por exclusão e é todo aquele dano que ou não tem valor econômico ou não pode ser quantificado com precisão. Em geral, esse dano moral será um dano moral de sofrimento, daí se falar em 'pretium doloris', mas algumas vezes haverá também dano moral que foge a essa caracterização, porque se trata de dano - e basta 


\section{Exatamente por representarem violações de natureza extrapatrimonial,}

entende-se que os danos morais não são objeto propriamente de uma indenização - na acepção tradicional do termo, que provém do latim e significa "tornar indene", isto é, eliminar o dano e suas consequências ${ }^{321}$ - mas sim de uma compensação: o objetivo é atribuir um valor em dinheiro ao lesado como forma de minorar os efeitos do dano moral sofrido $^{322}$.

pensar nas pessoas jurídicas, ou nas pessoas físicas que não têm condições de discernimento, ou ainda nos nascituros - que representa algum prejuízo não avaliável pecuniariamente de modo exato" ("Por uma Nova Categoria de Dano na Responsabilidade Civil: O Dano Social", in Novos Estudos e Pareceres de Direito Privado, São Paulo, Saraiva, 2009, p. 378); TERESA ANCONA LOPEZ: “(...) a definição de dano moral deveria ser dada em contraposição a dano material, sendo este o que lesa bens apreciáveis pecuniariamente e aquele, ao contrário, o prejuízo a bens ou valores que não têm conteúdo econômico . (...) Ora, o dano é sempre consequência de uma lesão a um direito, qualquer que seja sua origem, patrimonial ou não. Além disso, o que deve servir de medida ao dano não é o patrimônio, é a pessoa que tanto pode ser lesado no que é quanto pode ser lesada no que tem. Portanto, a distinção do dano em patrimonial e em não-patrimonial não se refere ao dano na sua origem, mas nos seus efeitos." ( $O$ Dano Estético: Responsabilidade Civil, cit., pp. 24-25); WILSON MELO DA SILVA: "Danos morais são lesões sofridas pelo sujeito físico ou pessoa natural de direito em seu patrimônio ideal, entendendo-se por patrimônio ideal, em contraposição a patrimônio imaterial, o conjunto de tudo aquilo que não seja suscetível de valor econômico" (O Dano Moral e Sua Reparação, $2^{\mathrm{a}}$ ed., São Paulo, Forense, 1969, p. 13); SILVIO RodRIGUES: “Trata-se assim de dano sem qualquer repercussão patrimonial" (Direito Civil - Responsabilidade Civil, cit., p. 189); MARIA Helena DinIZ: "Dano moral vem a ser a lesão de interesses não patrimoniais de pessoa natural ou jurídica (CC, art. 52; Súmula 227 do STJ), provocada pelo fato lesivo" (Curso de Direito Civil Brasileiro: Responsabilidade Civil, 24ª ed., São Paulo, Saraiva, 2010, p. 90); PONTES DE MIRANDA: “A expressão 'dano imaterial', como a expressão 'dano nãopatrimonial', substitui a outra, que tanto se emprega, 'dano moral' (Tratado de Direito Privado: Parte Especial - Direito das Obrigações, Tomo LIII, $3^{\mathrm{a}}$ ed., Rio de Janeiro, Editor Borsoi, 1972, p. 220); e ORLANDO GOMES: "Para defini-lo [o dano moral] com precisão, cumpre distinguir a lesão ao direito personalíssimo que repercute no patrimônio da que não repercute. Ocorrem as duas hipóteses. Assim, o atentado ao direito à honra e à boa fama de alguém pode determinar prejuízos na órbita patrimonial do ofendido ou causar apenas sofrimento moral. A expressão dano moral deve ser reservada exclusivamente para designar o agravo que não produz qualquer efeito patrimonial" (Responsabilidade Civil, Rio de Janeiro, Forense, 2011, p. 75).

${ }^{321}$ Conforme lição de MARIA CelinA Bodin DE MORAES: "Aquele que sofre o dano moral deve ter direito a uma satisfação de cunho compensatório. Diz-se compensação, pois o dano moral não é propriamente indenizável; 'indenizar' é palavra que provém do latim, 'in dene', que significa devolver (o patrimônio) ao estado anterior, ou seja, eliminar o prejuízo e suas consequências - o que, evidentemente, não é possível no caso de uma lesão de ordem extrapatrimonial. Prefere-se, assim, dizer que o dano moral é compensável, embora o próprio texto constitucional, em seu artigo $5^{\circ}, \mathrm{X}$, se refira à indenização do dano moral" (Danos à Pessoa Humana..., cit., p. 145).

${ }^{322}$ Sobre o tema, HANS ALBRECHT FISCHER já escrevia: "Daqui a pouco a pouco veremos como as legislações modernas foram ainda mais além no reconhecimento da indemnização em dinheiro destes danos imateriais. E, na realidade, a indemnização pecuniária não deveria ser repelida por ser meio insuficiente de reparar esta espécie de prejuízos, enquanto não fôsse encontrado um mais idóneo de o conseguir, um seu equivalente mais adequado. Pois, com efeito, a consciência de ter sido o autor do dano submetido a uma sanção penal não basta, evidentemente, para que seja compensado o prejuízo que se nos causou; além de que - e por cima disto - o direito penal moderno não estende a sua protecção a tôda a espécie de lesões não patrimoniais, nem, em boa verdade, tem de estendê-la, olhadas as coisas no plano dos fins que dominam a política criminal. Se a indemnização em dinheiro não pode desfazer por si a perturbação causada no nosso bem estar - no nosso equilíbrio moral -, pode, pelo menos, proporcionar a aquisição doutros bens que contribuam para a diminuição do dano" (A Reparação dos Danos, cit., pp. 236-237). 
A doutrina e a jurisprudência consolidaram entendimento no sentido de que um mesmo fato pode dar ensejo tanto à reparação tanto por danos patrimoniais como por danos morais, podendo haver cumulação de pedidos na mesma ação ${ }^{323}$.

Com relação à prova do dano moral, o entendimento doutrinário e jurisprudencial evoluiu no sentido de reconhecer o dever de reparar o dano mediante a simples prova da violação a um interesse extrapatrimonial, sendo desnecessária, em princípio, a prova da extensão do dano no âmbito subjetivo do lesado. No exemplo mais comum, uma vez provada a morte de um ente querido por homicídio, é desnecessária a prova de que tal fato resultou em sofrimento aos familiares da vítima, impondo-se o dever de indenizar, que exsurge in re ipsa, ou seja, do próprio fato da violação ${ }^{324}$. No entanto, em situações em que a extensão subjetiva do dano não possa ser presumida da natureza dos fatos, exige-se a demonstração, ainda que por via indireta, de que a ofensa repercutiu na vida do ofendido ${ }^{325}$.

Durante muito tempo, refutava-se a possibilidade de reparação de danos morais à pessoa jurídica, sob o fundamento de que estas não poderiam sofrer dor, humilhação e angústia como as pessoas físicas ${ }^{326}$. A partir da evolução da disciplina e da

${ }^{323}$ Sobre a possibilidade de cumulação da reparação por danos patrimoniais e morais, CARLOS ALBERTO BITTAR esclarece que "tem-se, assim, a cumulação de pedidos por danos morais e por danos materiais, perfeitamente admissível em uma só ação, dada a compatibilidade entre eles existente" (Reparação Civil por Danos Morais, cit., p. 242). TERESA ANCONA LOPEZ, por sua vez, sustenta que "os danos à pessoa têm tratamento autônomo e o dano moral é sempre puro. Os prejuízos materiais e morais se somam" ( $O$ Dano Estético: Responsabilidade Civil, cit., p. 25). Nesse sentido, a Súmula $n^{\circ} 37$ do Superior Tribunal de Justiça estabelece que "são cumuláveis as indenizações por dano material e dano moral oriundos do mesmo fato".

${ }^{324}$ Como esclarece CARLOS ALBERTO BITTAR: "Na concepção moderna da teoria da reparação dos danos morais prevalece, de início, a orientação de que a responsabilização do agente se opera por força do simples fato da violação. Com isso, verificado o evento danoso, surge, ipso facto, a necessidade de reparação, uma vez presentes os pressupostos de direito. Dessa ponderação, emergem duas consequências práticas de extraordinária repercussão em favor do lesado: uma, é a dispensa da análise da subjetividade do agente; outra, a desnecessidade de prova de prejuízo em concreto" (Reparação Civil por Danos Morais, cit., p. 214).

${ }^{325}$ Como esclarece Rui STOCO: "Mas uma coisa é certa. A doutrina evoluiu no sentido de exigir a prova do dano moral quando esteja in re ipsa, ainda que essa prova seja presuntiva e possa ser buscada por outros meios mais dúcteis e não se exija direta, tal como ocorre com o dano material. Significa dizer, em resumo, que o dano em si, porque imaterial, não depende de prova ou de aferição de seu quantum. Mas o fato e os reflexos que irradia, ou seja, a sua potencialidade ofensiva, dependem de comprovação ou pelo menos que esses reflexos decorram da natureza das coisas e levem à presunção segura de que a vítima, em face das circunstâncias, foi atingida em seu patrimônio subjetivo, seja com relação ao seu vultus, seja, ainda, com relação aos seus sentimentos, enfim, naquilo que lhe seja mais caro e importante" (Tratado de Responsabilidade Civil..., cit., p. 1716).

${ }^{326}$ No entendimento de WILSON MELO DA SILVA: "Seriam, pois, assim, para os efeitos dos danos morais, as pessoas jurídicas, meras abstrações, não tendo mais vida que a que lhes é emprestada pela inteligência ou pelo direito. Seriam vivas apenas para os juristas que lhes não podem comunicar, ao corpo, o quente calor 
própria mudança de concepção do dano moral - que, como visto acima, deixou de ser associado apenas às suas consequências no âmbito subjetivo do lesado - essa resistência foi sendo paulatinamente afastada. Desse modo, prevalece na doutrina atualmente o entendimento no sentido de admitir a possibilidade de dano moral à pessoa jurídica, independente do dano patrimonial, em caso de abalo à sua "honra objetiva"327, ou seja, o bom nome, imagem, reputação e credibilidade da pessoa jurídica ${ }^{328}$. Na jurisprudência, a Súmula 237 do Superior Tribunal de Justiça consolidou o entendimento de que "a pessoa jurídica pode sofrer dano moral".

Para concluir o panorama geral da reparação dos danos morais no direito brasileiro, deve-se mencionar que, também como resultado da superação da concepção exclusivamente subjetiva do dano moral, passou-se a admitir que a lesão ao patrimônio valorativo de determinada coletividade possa dar ensejo aos chamados danos morais coletivos $^{329}$. Como exemplos de danos morais coletivos, pode-se mencionar o dano ambiental, a ofensa à honra de determinada comunidade étnica ou religiosa e, como se verá no tópico seguinte, determinados danos oriundos de infrações à ordem econômica ${ }^{330}$. O

animal e a divina chama da alma, não tendo, pois, capacidade afetiva ou receptividade sensorial. Não se angustiam, não sofrem. Não seriam, jamais, suscetíveis dos danos anímicos que lhes não poderia insuflar a mais sutil casuística" (O Dano Moral e Sua Reparação, cit., p. 503).

${ }^{327}$ Como esclarece RUI STOCO, “a honra possui dois diferentes aspectos e busca duas vertentes: o subjetivo, que é interno e anímico, correspondendo aos sentimentos que não são inerentes à pessoa física, ou seja, ao ser humano, enquanto ser dotado de personalidade e sentimentos; assim como sua dignidade, decoro, dor e os sofrimentos d'alma, aspecto esse exclusivo do homem e o aspecto objetivo e externo, que se traduz na imagem e reputação perante terceiros, estes últimos comuns à pessoa física e a pessoa jurídica" (Tratado de Responsabilidade Civil..., p. 1766).

${ }^{328}$ Em sentido favorável à reparação do dano moral sofrido pela pessoa jurídica, vejam-se os entendimentos de Yussef Said Cahali (Dano Moral, cit., pp. 349-350); CARlos Alberto BitTAR (Reparação Civil por Danos Morais, cit., pp. 153-154); e AnTONIO JeOVÁ SAnTos, Dano Moral Indenizável, cit., pp. 140-144).

${ }^{329}$ Confira-se o seguinte julgado do Superior Tribunal de Justiça: “1. O dano moral coletivo, assim entendido o que é transindividual e atinge uma classe específica ou não de pessoas, é passível de comprovação pela presença de prejuízo à imagem e à moral coletiva dos indivíduos enquanto síntese das individualidades percebidas como segmento, derivado de uma mesma relação jurídica-base. 2. O dano extrapatrimonial coletivo prescinde da comprovação de dor, de sofrimento e de abalo psicológico, suscetíveis de apreciação na esfera do indivíduo, mas inaplicável aos interesses difusos e coletivos. 3. Na espécie, o dano coletivo apontado foi a submissão dos idosos a procedimento de cadastramento para o gozo do benefício do passe livre, cujo deslocamento foi custeado pelos interessados, quando o Estatuto do Idoso, art. 39, § $1^{\circ}$ exige apenas a apresentação de documento de identidade. 4. Conduta da empresa de viação injurídica se considerado o sistema normativo" (REsp 1057274/RS, Rel. Ministra Eliana Calmon, Segunda Turma, julgado em 01/12/2009, DJe 26/02/2010).

330 Sobre o tema, vide: CARlos Alberto BitTAR Filho, "Do Dano Moral Coletivo no Atual Contexto Jurídico Brasileiro", in Revista de Direito do Consumidor, vol. 12, São Paulo, Revista dos Tribunais, 1995; e LeONARDo Roscoe BesSA, "Dano Moral Coletivo", in Revista da Direito e Liberdade, v. 7, 2007. 
valor correspondente à reparação dos danos morais coletivos deve ser recolhido aos cofres públicos, nos termos do artigo 13 da Lei de Ação Civil Pública ${ }^{331}$.

\title{
5.2.4.2.2 Danos morais decorrentes da prática de cartel
}

Como visto acima, a reparação dos danos morais no ordenamento jurídico brasileiro é assegurada pela Constituição Federal e pelo Código Civil. Nesse contexto, não há qualquer razão para afastar a possiblidade de reparação por danos morais oriundos de infrações à ordem econômica ${ }^{332}$. Veja-se, a respeito, o posicionamento de LUIZ CARLOS BUCHAIN $^{333}$ :

\begin{abstract}
"Haveria dúvida sobre o direito a obter indenização por danos morais provados ao lesado a partir de determinados efeitos anticoncorrenciais? A resposta deverá ser negativa, pois onde o legislador não restringiu, não caberá ao intérprete fazê-lo. Ademais, a matéria está lavrada em nível constitucional, de onde deflui que a autorização à indenização por dano moral está inserida em todo o sistema jurídico, inclusive por pessoas jurídicas como reiteradamente e sumuladamente decidido pelo Superior Tribunal de Justiça".
\end{abstract}

Uma vez assentada a possibilidade de reparação por danos morais oriundos de infrações à ordem econômica, cabe avaliar as especificidades e hipóteses de cabimento da reparação por danos morais em casos de cartel. Devem ser analisadas três hipóteses distintas, conforme o dano seja sofrido por uma pessoa jurídica, por uma pessoa física ou por uma coletividade (danos morais coletivos).

\footnotetext{
331 “Art. 13. Havendo condenação em dinheiro, a indenização pelo dano causado reverterá a um fundo gerido por um Conselho Federal ou por Conselhos Estaduais de que participarão necessariamente o Ministério Público e representantes da comunidade, sendo seus recursos destinados à reconstituição dos bens lesados".

${ }^{332}$ Registre-se que o dano moral também é admissível mesmo em hipóteses de responsabilidade objetiva. Como esclarece RuI STOCO: “(...) em todos esses casos de responsabilidade objetiva, poder-se-á pleitear a reparação do dano moral independentemente da perquirição de culpa, desde que fique demonstrada a existência de nexo de causa e efeito entre o comportamento do agente e o resultado danoso. (...) Ainda que se cuide de responsabilidade objetiva, seja ela prevista no Código Civil (como ocorre em inúmeras passagens), seja a responsabilidade sem culpa do Estado (...), ou ainda em decorrência da prática de atos lícitos por parte da Administração Pública, há que se proteger a vítima” (Tratado de Responsabilidade Civil..., cit., p. 1696).

${ }^{333}$ O autor complementa: “A questão que se impõe é sabermos se a imposição de penas pela autoridade administrativa (autárquica) competente elide o direito da vítima ao pedido indenizatório de natureza moral. (...) a imposição de tais penas não elide o direito individual ao pedido indenizatório, seja ele patrimonial, moral ou misto" (O Poder Econômico e a Responsabilidade Civil Concorrencial, cit., pp. 165-166).
} 
No caso de pessoa jurídica, como analisado acima, admite-se a reparação por danos morais em caso de ofensa à sua "honra objetiva" (bom nome, imagem, reputação, credibilidade, etc.). Nesse sentido, como observa LUIZ CARLOS BUCHAIN, em determinados casos, como nos casos de concorrência desleal ${ }^{334}$, "o ato ilícito concorrencial praticado pelo agente detentor de poder de mercado pode ter por objeto a ofensa e a reputação da empresa prejudicada, exatamente como meio de obter seu afastamento do mercado" 335 .

Em se tratando de um cartel, poderá surgir o dever de indenizar caso o cartel gere prejuízos à reputação da pessoa jurídica. Isso pode ocorrer, por exemplo, no caso de a empresa não ter acesso a determinado insumo para fabricação de seus produtos - em razão das quantidades reduzidas e preços elevados fixados pelo cartel - e, por consequência, não conseguir honrar compromissos previamente assumidos com seus clientes, sofrendo, além de danos patrimoniais, abalo em sua reputação ${ }^{336}$. Nessas situações, a ofensa à reputação da pessoa jurídica deverá ser demonstrada, ainda que mediante prova indireta, não se aplicando em sua plenitude a teoria in re ipsa acima discutida ${ }^{337}$.

No caso de uma pessoa física, pode-se pensar no exemplo de um consumidor que, em virtude dos preços elevados decorrentes de um cartel, é obrigado a deixar de adquirir um bem, substituindo-o por outro que lhe proporciona menor utilidade. Como aponta LÍVIA GÂNDARA, "essa restrição, na medida em que afeta a liberdade, um dos

\footnotetext{
${ }^{334}$ Veja-se, nesse sentido, exemplo fornecido por Calixto Salomão Filho: "Imagine-se, por exemplo, a publicidade enganosa baseada na divulgação de informações falsas sobre o concorrente" (Direito Concorrencial-As Condutas, cit., p. 84).

${ }^{335}$ O Poder Econômico e a Responsabilidade Civil Concorrencial, cit., p. 168.

${ }^{336}$ Exemplo semelhante, embora não se trate de hipótese de cartel, é apontado por LUIZ CARLOS BUCHAIN: "Um exemplo que se pode construir como hipotética situação geradora de indenização moral e patrimonial de empresa, no âmbito da LDC, é a interrupção ou redução injustificada, pela empresa A de matéria-prima essencial à produção de bens de consumo pela empresa $\mathrm{B}$, e que vinha sendo regularmente fornecida, de tal forma que a esta última torna-se impossível cumprir as entregas já contratadas com seus distribuidores. A conduta ilícita de A considerada de forma una e indivisível, provocará em B danos patrimoniais (dano emergente representado pela perda da venda contratada e lucro cessante representado pela diminuição ou paralisação das atividades produtivas) quanto danos não-patrimoniais, dano esse vinculado à credibilidade da empresa no mercado, a manutenção da imagem e a confiabilidade no cumprimento dos contratos, os quais restam maculados tanto pela interrupção quanto pela descontinuidade nas entregas, ilicitamente provocadas pela empresa A" (O Poder Econômico e a Responsabilidade Civil Concorrencial, cit., p. 168).

337 Deve-se mencionar a posição de MARIA CELINA BODIN DE MORAES, que, embora admita que pessoas jurídicas possam sofrer danos não-patrimoniais, prefere chamar tais danos de "danos institucionais", os quais, segundo a autora, diferenciam-se do dano moral pela necessidade de comprovação potencial do prejuízo, não se aplicando a tese in re ipsa (Danos à Pessoa Humana..., cit., pp. 191-192).
} 
pilares da dignidade da pessoa humana - e, portanto, aspecto personalíssimo do indivíduo - provoca uma lesão de caráter moral e não patrimonial”,338.

Com relação aos danos morais coletivos, sua admissibilidade em matéria de responsabilidade civil concorrencial decorre de expressa previsão legal, uma vez que o artigo $1^{\circ}$ da Lei de Ação Civil Pública prevê a possibilidade de ajuizamento de "ações de responsabilidade por danos morais e patrimoniais causados" (...) "por infração da ordem econômica" (inciso V) ou "a qualquer outro interesse difuso ou coletivo" (inciso IV).

Nesse sentido, Bruno OliveIRA MAGGI, partindo da concepção de danos morais como aqueles danos que não podem ser reparados, mas apenas compensados, observa que o cartel reduz os incentivos das empresas para investirem na melhoria do atendimento e qualidade dos produtos, o que constitui um dano moral que atinge o mercado como um todo, gerando perdas coletivas. Além disso, o autor sustenta que o funcionamento do cartel resulta em "diminuição geral de bem-estar social”, observando que "o rebaixamento da qualidade de vida, a diminuição da produção e a impossibilidade de compra dos bens por potenciais compradores que pagariam o preço normal de mercado são situações que não podem ser revertidas", de modo que "a indenização poderá apenas compensar os valores perdidos"339.

De modo semelhante, PAulo Felipe Carneiro de Freitas sustenta que "quanto ao dano moral em matéria antitruste tem-se, como exemplo, um dano causado à coletividade pela mácula à instituição concorrência por meio de um cartel, trazendo danos pulverizados no mercado como desincentivo a investimentos, desaceleração de crescimento, etc."340-341.

\footnotetext{
338 "Responsabilidade Civil Concorrencial: Elementos de Responsabilidade Civil e Análise Crítica dos Problemas Enfrentados pelos Tribunais Brasileiros", in Revista do IBRAC, ano 19, vol. 21, 2012, p. 338.

339 O Cartel e seus Efeitos no Âmbito da Responsabilidade Civil, cit., pp. 144-157.

${ }^{340}$ Tutela Coletiva da Responsabilidade Civil por Infração da Ordem Econômica, cit., p. 54.

${ }^{341}$ LÍvIA GÂNDARA sustenta que os danos morais coletivos devem ter por parâmetro o "peso morto" gerado pelo cartel: “(...) é válido lembrar que uma determinada conduta anticompetitivas gera, não só prejuízos àqueles que de fato compraram os produtos ou contrataram os serviços, mas também àqueles que deixaram de comprar o produto ou serviço em razão, por exemplo, de um sobrepreço, compondo o chamado peso morto. Dessa forma, é possível relacionar o cálculo dos danos morais coletivos com a reparação do mais próximo que se possa chegar do peso morto gerado pela prática da conduta em razão deste representar com eficiência os danos provocados na sociedade" ("Responsabilidade Civil Concorrencial...", cit., p. 348).
} 
$\mathrm{Na}$ jurisprudência, em ações civis públicas pleiteando ressarcimento de prejuízos à coletividade causados pela prática de cartel, tem-se admitido, além do ressarcimento do sobrepreço (dano patrimonial), o cabimento de indenização por danos morais coletivos com o objetivo de reparar danos extrapatrimoniais decorrentes, nas palavras dos respectivos julgados, da "ofensa ao sentido de coletividade caracterizado pela espoliação sofrida pelos consumidores locais, gravemente maculados em sua vulnerabilidade",342 e da "diminuição do bem-estar dos consumidores traduzida na sensação de impotência e de descrédito nas instituições públicas"343.

Em síntese, a doutrina e a incipiente jurisprudência sobre o tema admitem a reparação de danos morais (individuais e coletivos) ocasionados pelos cartéis, os quais são associados às consequências do cartel cujo conteúdo econômico não é mensurável, tais como a redução dos incentivos à inovação e qualidade, a redução geral de bem-estar dos consumidores e os prejuízos decorrentes da exclusão de potenciais consumidores do mercado em razão de preços elevados. Esses efeitos decorrentes do cartel, que atingem o mercado e a economia como um todo, foram examinados no capítulo 1, que examinou a prática de cartel sob a perspectiva econômica.

\subsection{Fixação da indenização por danos morais}

Depois de traçado o panorama geral da disciplina dos danos morais no direito brasileiro, e após examinadas as hipóteses de danos morais e danos morais coletivos oriundas da prática de cartel, cabe analisar um tema que suscita importantes discussões: a quantificação dos danos morais.

\footnotetext{
342 "Dano moral coletivo: os danos morais coletivos decorrem do reconhecimento da dimensão extrapatrimonial dos interesses coletivos, sejam eles de categoria difusa, coletiva 'strictu sensu' ou individual homogênea, não se confundindo com o interesse público (primário) ou com os direitos individuais. Necessidade de ampla reparação dos danos ensejados pela ofensa a esses direitos, inclusive de natureza extrapatrimonial. Caracterização no caso concreto, de dano moral coletivo consistente na ofensa ao sentimento de coletividade, caracterizado pela espoliação sofrida pelos consumidores locais, gravemente maculados em sua vulnerabilidade" (TJ/RS, Apelação Cível no 70018714857, 3ª Câmara Cível, Rel. Paulo de Tarso Vieira Sanseverino, j. 12.07.2007).

343 “A conduta das rés deu causa a uma diminuição de bem estar nos consumidores, traduzida na sensação de impotência e de descrédito nas instituições públicas. O interesse lesado, no caso, é difuso, de modo que deveras não há como identificar os lesados, tampouco mensurar o dano. Porém, isso não impede a condenação, que no caso tem finalidade mais educativa do que compensatória do dano" (Ação Civil Pública n 291.01.2006.000904-1, Auto Posto S. Gomes Ltda. e outros, Juíza de Direito Carmen Silva Alves, Comarca de Jaboticabal - SP).
} 
Conforme analisado nos tópicos acima, o valor atribuído ao lesado a título de danos morais não corresponde propriamente a uma indenização, mas a uma compensação pecuniária como forma de minorar os efeitos causados pela lesão sofrida. Desse modo, a fixação do quantum indenizatório a título de danos morais não segue os mesmos critérios empregados para a quantificação dos danos patrimoniais. Nesse sentido, entende-se que os danos morais devem ser arbitrados segundo o prudente critério do julgador $^{344}$.

Ao se desincumbir da tarefa de arbitrar o valor da indenização por danos morais, a jurisprudência brasileira tem reconhecido a existência de uma dupla função dos danos morais, a saber: de um lado, compensar a vítima pela lesão sofrida e, de outro, punir $\mathrm{o}$ infrator como forma de desestímulo à prática de novas infrações ${ }^{345}$. Trata-se da chamada teoria do valor do desestímulo, a qual tem sido aceita pelo Superior Tribunal de Justiça ${ }^{346}$.

$\mathrm{Na}$ doutrina, as posições se dividem com relação à função punitiva dos danos morais reconhecida pela jurisprudência. As diferentes posições sobre o tema podem ser agrupadas nas seguintes categorias:

\footnotetext{
${ }^{344}$ Segundo CARlos Alberto BitTAR, "tem-se, pois, como regra geral, em matéria de determinação da reparação, a outorga ao juiz de poderes amplos, contando ele, no respectivo exercício, com certas fórmulas, engendradas na vivência prática, que lhe servem de apoio para a ministração da justiça. Com isso, na definição da indenização devida, compete ao juiz perseguir, em vista das condições do litígio, o real sentido dos fatos, para aquilatar das fórmulas que melhor se ajustam à hipótese vertente, atento sempre ao princípio basilar da reparação integral ao lesado" (Reparação Civil por Danos Morais, cit., p. 220). Sobre o tema, CARLOS ROBERTO GONÇALVES esclarece que "as leis em geral não costumam formular critérios ou mecanismos para a fixação do quantum da reparação, a não ser em algumas hipóteses, preferindo deixar ao prudente arbítrio do juiz a decisão, em cada caso. Por essas razões, a jurisprudência tem procurado encontrar soluções e traçar alguns parâmetros, desempenhando importante papel nesse particular" (Responsabilidade Civil, cit., p. 674).

${ }^{345}$ Sobre o tema, JUDITH MARTINS-COSTA e MARIANA SOUZA PARGENDLER esclarecem que "coexistem três correntes, em sede tanto doutrinária como jurisprudencial, sobre a função da indenização do dano moral, quais sejam, a compensação/satisfação do ofendido, a punição do ofensor e tanto a satisfação do ofendido como a punição do ofensor. (...) Ao acolher-se a função punitiva ou a função mista (satisfação/punição) da indenização, a jurisprudência utiliza, para a fixação do quantum indenizatório, a combinação de dois e, por vezes, de três distintos critérios: o grau de culpa do ofensor; a condição econômica do responsável pela lesão; e o enriquecimento obtido com o fato ilícito" ("Usos e Abusos da Função Punitiva (Punitive Damages e o Direito Brasileiro)", in Revista CEJ, n. 29, Brasília, jan./mar., 2005, p. 23).

${ }^{346}$ Veja-se, a respeito, o seguinte julgado do Superior Tribunal de Justiça: “(...) valor fixado a título de indenização por dano moral, que não pode ser ínfimo ou abusivo, mas proporcional à dúplice função deste instituto indenizatório: reparação do dano, buscando minimizar a dor da vítima, e punição do ofensor, para que não volte a reincidir" (STJ, Recurso Especial no 604.801-RS, 2 ${ }^{\mathrm{a}}$ Turma, Rel. Eliana Calmon, j. 23.03.2004).
} 

reparação por danos morais, com caráter educativo e punitivo, com o objetivo de desestimular a prática de novas infrações ${ }^{347}$;

ii) de outro lado, há autores que criticam os critérios atualmente adotados pela jurisprudência para fixação dos danos morais, sendo que, nesse grupo: (a) há autores que simplesmente são contrários à aplicação da teoria do desestímulo na fixação do quantum indenizatório por danos morais ${ }^{348}$; e (b) há autores que, embora

\begin{abstract}
${ }^{347}$ Vejam-se as posições de CARLOS Alberto BitTAR: “Adotada a reparação pecuniária - que, aliás, é a regra na prática, diante dos antecedentes expostos -, vem-se cristalizando orientação na jurisprudência nacional que, já de longo tempo, domina o cenário indenizatório nos direitos norte-americano e inglês. É a da fixação de valor que serve como desestímulo a novas agressões, coerente com o espírito dos referidos punitive ou exemplary damages da jurisprudência daqueles países. Em consonância com essa diretriz, a indenização por danos morais deve traduzir-se em montante que represente advertência ao lesante e à sociedade de que não se aceita o comportamento assumido, ou o evento lesivo advindo. Consubstancia-se, portanto, em importância compatível com o vulto dos interesses em conflito, refletindo-se, de modo expressivo, no patrimônio do lesante, a fim de que sinta, efetivamente, a resposta da ordem jurídica aos efeitos do resultado lesivo produzido" (Reparação Civil por Danos Morais, cit., pp. 232-233); RUI STOCO: "A tendência moderna, ademais, é a aplicação do binômio punição e compensação, ou seja, a incidência da teoria do valor do desestímulo (caráter punitivo da sanção pecuniária) juntamente com a teoria da compensação, visando destinar à vítima uma soma que compense o dano moral sofrido. (...) A nós parece que os fundamentos básicos que norteiam a fixação do quantum em hipóteses de ofensa moral encontram-se no seu caráter punitivo e compensatório, embora essa derivação para o entendimento de punição/prevenção não tenha grande significado, na consideração de que na punição está subentendida a própria prevenção. Isto é: a punição já tem o sentido e propósito de prevenir para que não se reincida" (Tratado de Responsabilidade Civil..., cit., p. 1732); YUSSEF SAID CAHALI: "A indenizabilidade do dano moral desempenha uma função tríplice: reparar, punir, admoestar ou prevenir” (Dano Moral, cit., p. 175); SÉRGIO CAVALIERI FILHO: “(...) a indenização punitiva do dano moral deve também ser adotada quando o comportamento do ofensor se revelar particularmente reprovável - dolo ou culpa grave - e, ainda, nos casos em que, independentemente de culpa, o agente obtiver lucro com o ato ilícito ou incorrer em reiteração da conduta ilícita" (Programa de Responsabilidade Civil, cit., p. 99); SILVIO DE SALVo VenOSA: "De qualquer modo, em sede de indenização por danos imateriais há que se apreciar sempre a conjugação dos três fatores ora mencionados: compensação, dissuasão e punição. Dependendo do caso concreto, ora ponderará um, ora ponderará outro, mas os três devem ser levados em consideração. Como se nota, os novos paradigmas da responsabilidade civil exigem que hoje os julgados se voltem para novos valores que muito pouco têm a ver com o sentido histórico da responsabilidade civil aquiliana" (Direito Civil - Responsabilidade Civil, cit., p. 346); e ANTONIO JeOvá SANTOS: "Muito embora vozes abalizadas se oponham à indenização que tenha caráter penal, não se pode afastar de todo que no montante indenizatório do dano moral, deve o juiz estipular certa quantia como fator dissuasivo da prática de novos danos" (Dano Moral Indenizável, cit., p. 157).
\end{abstract}

${ }^{348}$ Nesse sentido são os posicionamentos de CARLOS ROBERTO GONÇALVES: "Não se justifica, pois, como pretendem alguns, que o julgador, depois de arbitrar o montante suficiente para compensar o dano moral sofrido pela vítima (e que, indireta e automaticamente, atuará como fator de desestímulo ao ofensor), adicione-lhe um plus a título de pena civil, inspirando-se nas punitive damages do direito norte-americano. É preciso considerar as diferenças decorrentes das condições econômicas, raízes históricas e costumes, bem como o conteúdo e os limites dos poderes de que se acham investidos os juízes e ainda o sistema de seguros dos Estados Unidos da América do Norte. Diversamente do direito norte-americano, inspira-se o nosso sistema jurídico na supremacia do direito legislado, a qual está expressa no preceito constitucional de que ninguém será obrigado a fazer ou deixar de fazer alguma coisa senão em virtude de lei (...). Já se foi o tempo em que as sanções civis e penais se confundiam. A sanção penal tem por fim a repressão do ato ilícito e não 
defendam a adoção, via reforma legislativa, de indenização com caráter punitivo no direito brasileiro, criticam a forma como a função punitiva vem sendo aplicada pela jurisprudência no tocante à reparação do dano moral, denunciando a ausência de parâmetros claros para que se possa aferir o montante da punição ${ }^{349-350}$.

guarda relação com o valor do bem lesado. Por aí se vê que o caráter sancionatório autônomo, nas condições mencionadas, tem todas as características da sanção penal. Enquanto tal, está sujeita ao princípio da legalidade das penas, conforme se acha expresso na Constituição Federal: não há pena 'sem prévia cominação legal' (art. $5^{\circ}$, XXXIX). Não cabe ao juiz, mas ao legislador, estabelecer os seus limites máximos e mínimos. Do contrário, ficaria a critério de cada um fixar a pena que bem entendesse. Enquanto garantia constitucional, o princípio da legalidade das penas não se aplica exclusivamente ao direito penal" (Responsabilidade Civil, cit., pp. 677-678); HUMBERTO THEODORO JÚNIOR: "Não cabe ao juiz civil transmudar o julgamento da ação de responsabilidade civil num instrumento de aplicação de pena ao infrator, se nenhuma lei expressamente o autorizou a tanto. Em nosso sistema constitucional só a lei pode instituir pena aplicável ao agente do ato ilícito. Se nenhuma norma legal cogita de instituir ou cominar pena para determinado ato lesivo, ao juiz civil somente toca impor ao agente o dever de indenizar o prejuízo acarretado à vítima. Nada mais" (Dano Moral, 4a ed., São Paulo, Juarez de Oliveira, 2001, p. 65); ANDERSON SCHREIBER: “A orientação jurisprudencial, a rigor, contraria expressamente o Código Civil de 2002, que, em seu art. 944, declara: 'a indenização mede-se pela extensão do dano'. Pior: ao combinar critérios punitivos e critérios compensatórios, chegando-se a um resultado único, a prática brasileira distancia-se do modelo norteamericano, que distingue claramente compensatory damages e punitive damages. Com isso, cria-se, no Brasil, uma espécie bizarra de indenização, em que ao responsável não é dado conhecer em que medida está sendo apenado, e em que medida está simplesmente compensando o dano, atenuando, exatamente, o efeito dissuasivo que consiste na principal vantagem do instituto" (Novos Paradigmas da Responsabilidade Civil..., cit., pp. 212-213).

349 Nesse sentido, as posições de DANIEL DE ANDRADE LEVY: “A jurisprudência foi o principal fator responsável pela consolidação desses critérios 'normativos' entre nós, ao criar um dano moral 'exemplar', 'pedagógico', 'punitivo', com caráter de 'desestímulo'. Portanto, a função punitiva tem sido afirmada em vários acórdãos, seja explicitamente, nas expressões supra, ou implicitamente, adotando critérios como a gravidade da ofensa, a situação econômica do agente ou o seu grau de culpa. O que preocupa é constatar que o magistrado tem atuado sem qualquer respaldo legislativo. Em suma, convive-se, hoje, no Brasil, com uma 'espécie bizarra de indenização', que, embora não seja reconhecida formalmente como punitiva, reflete critérios que obram nessa direção, gerando absurda insegurança jurídica tanto para a vítima quanto para o ofensor. (...) A esquizofrenia do dano moral talvez seja, hoje, o mais grave problema da Responsabilidade Civil brasileira. Mostra que a função punitiva da disciplina continua constrangida sob figuras totalmente imprevisíveis, tanto em quantidade quanto em qualidade. Enquanto não se refletir acerca de uma categoria autônoma de indenização punitiva, ou ao menos de uma verba autônoma no âmbito dos danos morais, deverá o jurisdicionado contentar-se com um esforço de fundamentação das decisões que nem sempre se coaduna com a nossa carregada justiça” (Responsabilidade Civil..., cit., pp. 75-79); e DioGO NAVES MENDONÇA: "Os próprios critérios de que se vale o STJ, acima mencionados, guardam um alto grau de subjetividade, que tem seus efeitos trágicos potencializados quando se observa que aquele tribunal opta por não definir em que medida eles estão sendo usados para compensar e em que medida são invocados para punir. Ao final, é simplesmente impossível saber (i) qual o montante compensatório, (ii) qual o montante punitivo e (iii) como se chegou a cada um deles. Se deliberada ou não, a postura acaba por criar um indesejável grau de incerteza no que se refere à indenização por danos extrapatrimoniais. Diante disso, o debate acerca da admissibilidade da função punitiva na quantificação do dano moral acaba encontrando pouca repercussão prática. É que a corte responsável por dar a palavra final no assunto vale-se dos termos compensação e punição como recursos retóricos, em um topos que se reproduz de forma praticamente mecânica" (Análise Econômica da Responsabilidade Civil..., cit., pp. 90-91).

350 Registre-se a posição de MARIA CELINA BODIN DE MORAES que, embora critique com veemência a aplicação indiscriminada da tese do caráter punitivo dos danos morais, defende sua adoção em "hipóteses excepcionais e taxativamente previstas em lei”, quando se tratar "por exemplo, de conduta particularmente ultrajante, ou insultuosa, em relação à consciência coletiva, ou, ainda quando se der o caso, não incomum, de prática danosa reiterada" (Danos à Pessoa Humana..., cit., p. 263). 
Compartilhamos da crítica de parcela da doutrina no sentido de que a jurisprudência deveria explicitar com maior precisão os critérios adotados na fixação do quantum indenizatório por danos morais, discriminando o montante atribuído a título de compensação e aquele fixado como desestímulo.

Além disso, entendemos que, em matéria concorrencial, a função punitiva dos danos morais deve ser empregada com bastante cautela pelos tribunais, de modo a afastar o risco de indevida sobreposição com as atividades de repressão de condutas anticompetitivas exercidas pelo CADE, Ministério Público e órgãos policiais. Conforme analisado no capítulo 2, acima, além de ficarem obrigados a reparar os prejuízos causados, os envolvidos na prática de cartel também ficam sujeitos a penalidades nas esferas administrativa e penal.

Nesse sentido, vale transcrever a observação de MARIA CELINA Bodin DE MORAES, que, analisando o caráter punitivo atribuído ao dano moral pelos tribunais, aponta para o risco de "bis in idem" entre as esferas penal e civil ${ }^{351}$ :

\begin{abstract}
"A este respeito, é de se ressaltar ainda que grande parte dos danos morais, aos quais se pode impor o caráter punitivo, configura-se também como crime. Abre-se, com o caráter punitivo, não apenas uma brecha, mas uma verdadeira fenda num sistema que sempre buscou oferecer todas as garantias contra o injustificável bis in eadem. O ofensor, neste caso, estaria sendo punido duplamente, tanto em sede civil como em sede penal, considerandose, ainda, de relevo o fato de que as sanções pecuniárias cíveis têm potencial para exceder, em muito, as correspondentes do juízo criminal".
\end{abstract}

Especificamente em relação à responsabilidade civil por cartel, BRUNO OLIVEIRA MAGGI também manifesta preocupação com o risco de sobreposição entre o critério punitivo do dano moral e as esferas administrativa e penal de repressão a cartéis $^{352}$ :

"Dada a relevância do dano, o ato pode ser previsto como crime ou infração administrativa e o agente já seria sancionado. Portanto, o dano à sociedade deve ser analisado com cautela no momento de verificar os prejuízos resultantes para a quantificação da indenização, pois não pode haver sobreposição com o direito penal e direito administrativo. A indenização não poderá ser apoiada totalmente sobre o seu critério punitivo se inexistirem perdas a serem compensadas e se o ato praticado for tipificado penalmente

\footnotetext{
${ }^{351}$ Danos à Pessoa Humana..., cit., p. 260.

${ }^{352}$ O Cartel e seus Efeitos no Âmbito da Responsabilidade Civil, cit., pp. 143-144.
} 
ou previsto como infração administrativa. Nesses casos, o dano-evento à sociedade existe, mas o dano-prejuízo gerado é apenas moral, podendo ser apenas compensado. No caso de um cartel que tenha sido condenado pelo CADE, por exemplo, os agentes já foram sancionados e a multa paga, enquanto que no caso do descumprimento em massa de contratos por uma grande empresa a fixação de indenização em valor superior ao necessário para a reparação do prejuízo serviria como desestímulo à prática, visto que esse ato não é punido por qualquer lei e, tomado isoladamente, poderia no máximo configurar um abuso de direito".

O risco de sobreposição e multiplicidade de punições é ainda maior com relação aos danos morais coletivos, uma vez que é entendimento consolidado na doutrina que os danos morais coletivos constituem uma forma de punição ao infrator pelos danos causados à coletividade ${ }^{353-354}$. Tanto é assim que o valor da condenação a título de danos morais coletivos deve ser recolhido ao Fundo de Defesa dos Direitos Difusos - o mesmo para o qual são recolhidas as multas impostas pelo $\mathrm{CADE}^{355}$-, o que ressalta ainda mais as semelhanças entre a atividade de repressão a cartéis exercida pelo CADE e a condenação a título de danos morais coletivos pela prática de cartel.

\footnotetext{
${ }^{353}$ Sobre o tema, vejam-se as posições de DANIEL DE ANDRADE LEVY: "A última forma subliminar de instrumentalização da função punitiva na Responsabilidade Civil tem se dado pelas hipóteses, cada vez mais comuns, de 'dano moral coletivo' (...) Logo, o dano moral coletivo é mais uma forma de canalização do caráter normativo da Responsabilidade Civil nas sociedades que penam a aceitar uma categoria mais bem delineada de indenização punitiva" (Responsabilidade Civil..., pp. 88-90); NELSON ROSENVALD: "O modelo jurídico do dano moral coletivo (...) não passa de peculiar espécie de penal civil criativamente desenhada no ordenamento brasileiro, em nada se assemelhando com a natureza do dano extrapatrimonial" (As Funções da Responsabilidade Civil..., p. 200); e LEONARDO RosCOE BESSA: "A condenação por dano moral coletivo é sanção pecuniária por violação a direitos coletivos ou difusos. O valor imposto pelo juiz é destinado ao fundo criado pelo art. 13 da Lei 7.347/85 (Lei da Ação Civil Pública). O caráter da condenação é exclusivamente punitivo" ("Dano Moral Coletivo", cit., p. 271).

${ }^{354}$ Em tese de doutorado sobre o tema, FERNANDA ORSI BALTRUNAS DORETTO também destaca a natureza punitiva do dano moral coletivo e ressalta o eventual risco de sobreposição com a punição em outras esferas: "Esses valores devidos a título de danos morais terão caráter punitivo e deverão ser depositados no fundo criado pelo artigo 13 da Lei da Ação Civil Pública. O problema que se afigura é a necessidade de reparação individual, e a cumulação das indenizações, fazendo com que o lesando sofra um ônus excessivo pelo ilícito. Pode-se imaginar, por exemplo, que um ilícito ambiental ou um ilícito praticado contra os consumidores pode, além de causar prejuízos ao patrimônio moral coletivo, causar prejuízos individuais, que deverão ser devidamente reparados. Como, então, dar medida à indenização por danos morais de caráter punitivo, sem que isso crie um excesso de penas para o autor do ilícito? A experiência americana demonstra que esse é o grande perigo das indenizações punitivas, o chamado overkill. O desejo de reparar o dano causado a cada um dos lesados acaba por consumir todo o patrimônio do autor do ilícito. Não há como conferir uma solução para o problema. A situação que se afigura deverá contar com o discernimento não só do autor da ação para a defesa de interesses coletivos, bem como do julgador da demanda (...)" (Dano Moral Coletivo, Tese de Doutorado, Faculdade de Direito da Universidade de São Paulo, 2008, pp. 112-113).
}

${ }^{355}$ Nos termos do artigo $1^{\circ}$, § $2^{\circ}$ da Lei $n^{\circ} 9.008$, de 21 de março de 1995, "constituem recursos do FDD o produto da arrecadação: I - das condenações judiciais de que tratam os arts. 11 e 13 da Lei no 7.347, de 1985; (...) V - das multas referidas no art. 84 da Lei no 8.884, de 11 de junho de 1994". 
Nesse contexto, conclui-se que, na hipótese de o cartel já ter sido punido na esfera administrativa (ou penal), tal fato deverá ser levado em conta pelo julgador ao fixar o quantum indenizatório por dano moral, de modo a afastar eventual "bis in idem”, ou seja, a multiplicidade de punições por um mesmo fato.

Pode-se também sustentar que o próprio CADE, ao fixar as penalidades na esfera administrativa, deva levar em conta eventual verba indenizatória paga pelos representados a título de dano moral (individual ou coletivo) com caráter punitivo em virtude da mesma infração à ordem econômica. Nessa hipótese, o valor da condenação na esfera administrativa também deveria sofrer redução como forma de evitar o "bis in idem". Note-se que o artigo 45 da Lei $12.529 / 2011^{356}$, que estabelece os parâmetros a serem levados em conta pelo CADE na aplicação de penalidades, contém alguns critérios - tais como a vantagem auferida pelo infrator e sua situação econômica - que permitem interpretação no sentido de descontar do valor da multa eventual verba já paga pelo infrator a título de punição.

\subsection{Interação entre as ações indenizatórias e o programa de leniência no direito brasileiro}

Depois de concluída a análise dos pressupostos da responsabilidade civil no direito brasileiro, este tópico analisará a interação entre as ações indenizatórias e o programa de leniência no Brasil, tema que, como visto no capítulo 4, é objeto de importantes discussões nos direitos norte-americano e europeu.

\subsubsection{O acordo de leniência no direito brasileiro}

No direito brasileiro, o acordo de leniência é disciplinado pelo artigo 86 da Lei 12.529/2011, que prevê a possibilidade de o CADE, por intermédio da Superintendência-Geral, celebrar acordo de leniência com pessoas físicas e jurídicas, prevendo-se a extinção da ação punitiva da administração pública ou redução de 1/3 (um

\footnotetext{
356 “Art. 45. Na aplicação das penas estabelecidas nesta Lei, levar-se-á em consideração: I - a gravidade da infração; II - a boa-fé do infrator; III - a vantagem auferida ou pretendida pelo infrator; IV - a consumação ou não da infração; V - o grau de lesão, ou perigo de lesão, à livre concorrência, à economia nacional, aos consumidores, ou a terceiros; VI - os efeitos econômicos negativos produzidos no mercado; VII - a situação econômica do infrator; e VIII - a reincidência”.
} 
terço) a 2/3 (dois terços) da penalidade aplicável ${ }^{357}$, bem como a extinção da punibilidade com relação aos crimes contra a ordem econômica e demais crimes relacionados à prática de cartel (art. 87) ${ }^{358}$.

Para poder usufruir dos benefícios da leniência, o signatário do acordo de leniência deve colaborar efetivamente com as investigações e, dessa colaboração, deve

357 “Art. 86. O Cade, por intermédio da Superintendência-Geral, poderá celebrar acordo de leniência, com a extinção da ação punitiva da administração pública ou a redução de 1 (um) a $2 / 3$ (dois terços) da penalidade aplicável, nos termos deste artigo, com pessoas físicas e jurídicas que forem autoras de infração à ordem econômica, desde que colaborem efetivamente com as investigações e o processo administrativo e que dessa colaboração resulte: I - a identificação dos demais envolvidos na infração; e II - a obtenção de informações e documentos que comprovem a infração noticiada ou sob investigação. § $10 \mathrm{O}$ acordo de que trata o caput deste artigo somente poderá ser celebrado se preenchidos, cumulativamente, os seguintes requisitos: I - a empresa seja a primeira a se qualificar com respeito à infração noticiada ou sob investigação; II - a empresa cesse completamente seu envolvimento na infração noticiada ou sob investigação a partir da data de propositura do acordo; III - a Superintendência-Geral não disponha de provas suficientes para assegurar a condenação da empresa ou pessoa física por ocasião da propositura do acordo; e IV - a empresa confesse sua participação no ilícito e coopere plena e permanentemente com as investigações e o processo administrativo, comparecendo, sob suas expensas, sempre que solicitada, a todos os atos processuais, até seu encerramento. § 2o Com relação às pessoas físicas, elas poderão celebrar acordos de leniência desde que cumpridos os requisitos II, III e IV do § 1 o deste artigo. § $30 \mathrm{O}$ acordo de leniência firmado com o Cade, por intermédio da Superintendência-Geral, estipulará as condições necessárias para assegurar a efetividade da colaboração e o resultado útil do processo. $\S 40$ Compete ao Tribunal, por ocasião do julgamento do processo administrativo, verificado o cumprimento do acordo: I - decretar a extinção da ação punitiva da administração pública em favor do infrator, nas hipóteses em que a proposta de acordo tiver sido apresentada à Superintendência-Geral sem que essa tivesse conhecimento prévio da infração noticiada; ou II - nas demais hipóteses, reduzir de 1 (um) a $2 / 3$ (dois terços) as penas aplicáveis, observado o disposto no art. 45 desta Lei, devendo ainda considerar na gradação da pena a efetividade da colaboração prestada e a boa-fé do infrator no cumprimento do acordo de leniência. § 5o Na hipótese do inciso II do § 4o deste artigo, a pena sobre a qual incidirá o fator redutor não será superior à menor das penas aplicadas aos demais coautores da infração, relativamente aos percentuais fixados para a aplicação das multas de que trata o inciso I do art. 37 desta Lei. § 6o Serão estendidos às empresas do mesmo grupo, de fato ou de direito, e aos seus dirigentes, administradores e empregados envolvidos na infração os efeitos do acordo de leniência, desde que o firmem em conjunto, respeitadas as condições impostas. § 7o A empresa ou pessoa física que não obtiver, no curso de inquérito ou processo administrativo, habilitação para a celebração do acordo de que trata este artigo, poderá celebrar com a Superintendência-Geral, até a remessa do processo para julgamento, acordo de leniência relacionado a uma outra infração, da qual o Cade não tenha qualquer conhecimento prévio. § 8o Na hipótese do § 7o deste artigo, o infrator se beneficiará da redução de $1 / 3$ (um terço) da pena que lhe for aplicável naquele processo, sem prejuízo da obtenção dos benefícios de que trata o inciso I do § 4o deste artigo em relação à nova infração denunciada. § 9o Considera-se sigilosa a proposta de acordo de que trata este artigo, salvo no interesse das investigações e do processo administrativo. § 10. Não importará em confissão quanto à matéria de fato, nem reconhecimento de ilicitude da conduta analisada, a proposta de acordo de leniência rejeitada, da qual não se fará qualquer divulgação. § 11. A aplicação do disposto neste artigo observará as normas a serem editadas pelo Tribunal. § 12. Em caso de descumprimento do acordo de leniência, o beneficiário ficará impedido de celebrar novo acordo de leniência pelo prazo de 3 (três) anos, contado da data de seu julgamento".

358 “Art. 87. Nos crimes contra a ordem econômica, tipificados na Lei no 8.137, de 27 de dezembro de 1990, e nos demais crimes diretamente relacionados à prática de cartel, tais como os tipificados na Lei no 8.666, de 21 de junho de 1993, e os tipificados no art. 288 do Decreto-Lei ${ }^{\circ} 2.848$, de 7 de dezembro de 1940 Código Penal, a celebração de acordo de leniência, nos termos desta Lei, determina a suspensão do curso do prazo prescricional e impede o oferecimento da denúncia com relação ao agente beneficiário da leniência. Parágrafo único. Cumprido o acordo de leniência pelo agente, extingue-se automaticamente a punibilidade dos crimes a que se refere o caput deste artigo". 
resultar a identificação dos demais envolvidos na infração (art. 86, inc. I), bem como a obtenção de informações e documentos que comprovem a infração noticiada ou sob investigação (art. 86, inc. II). A empresa deve ser a primeira a se qualificar com respeito à infração noticiada ou sob investigação (art. $86, \S 1^{\circ}$, inc. I) e deve cessar totalmente o seu envolvimento na infração a partir da data da propositura do acordo (art. $86, \S 1^{\circ}$, inc. II). O acordo somente será celebrado na hipótese de a Superintendência-Geral não dispor de provas suficientes para a condenação da empresa ou pessoa física por ocasião da proposta de acordo (art. $86, \S 1^{\circ}$, inc. III).

O Regimento Interno do CADE contém normas complementares sobre a celebração de acordo de leniência (cf. art. 86, § $11^{\circ}$ da Lei 12.529/2011). De acordo com o artigo 206 e respectivos incisos do Regimento Interno do CADE, o acordo de leniência deve conter, dentre outros requisitos, a confissão expressa do signatário (inc. V), a exposição detalhada dos fatos relativos à infração, com identificação dos autores, produtos ou serviços afetados, área geográfica e duração da infração (inc. IV), bem como a lista dos documentos e informações fornecidas pelo signatário do acordo de leniência (inc. VII).

Nesse contexto, aqueles que pretendem usufruir dos benefícios do programa de leniência devem: (i) assinar o acordo de leniência, documento firmado pelo beneficiário e pelas autoridades de defesa da concorrência, o qual, além de contém a confissão expressa do beneficiário, disciplina as obrigações e condições segundo as quais o beneficiário poderá usufruir dos benefícios do programa de leniência; (ii) descrever pormenorizadamente os fatos relacionados à infração, o que costuma ser feito em documento denominado "Histórico da Conduta", o qual é parte integrante do acordo de leniência; e (iii) entregar às autoridades as evidências em seu poder que constituam prova da infração noticiada (e.g., e-mails trocados entre os membros do cartel, planilhas de preços, dentre outras).

\subsubsection{Acesso dos prejudicados às confissões e documentos disponibilizados pelos beneficiários da leniência}

Depois de expostas as principais características do programa de leniência brasileiro, a dúvida que surge é se os prejudicados pela prática de cartel e outras infrações à ordem econômica teriam direito de ter acesso aos documentos disponibilizados pelos 
signatários de acordo de leniência - tais como o próprio acordo de leniência, o Histórico da Conduta e as evidências disponibilizadas às autoridades (e-mails, planilhas, etc.).

Trata-se de situação na qual há conflito entre dois valores:

i) de um lado, o interesse dos prejudicados em viabilizar o ressarcimento dos prejuízos causados pelos infratores, eis que o acesso aos documentos e declarações apresentadas pelo signatário do acordo de leniência pode facilitar a prova da existência do cartel, dos prejuízos causados pela prática e do nexo de causalidade, facilitando a obtenção de indenização;

ii) de outro lado, o interesse institucional em preservar o programa de leniência, o qual constitui importante instrumento de detecção de cartéis; nesse sentido, considerando que o acordo de leniência não confere imunidade em âmbito civil, a divulgação dos documentos e das declarações fornecidas pelo beneficiário incluindo o teor da confissão e as informações constantes do Histórico da Conduta - pode aumentar as chances de o signatário ser condenado a indenizar os prejuízos, colocando-o, no tocante à ação indenizatória, em situação mais desvantajosa do que a dos demais membros do cartel; desse modo, a divulgação desses documentos e declarações pode reduzir os incentivos para que os infratores celebrem acordos de leniência $^{359}$.

No direito comunitário europeu, essa questão foi analisada no julgamento do chamado "Caso Pfleiderer", considerado paradigmático sobre o assunto, em que o Tribunal de Justiça da União Europeia, respondendo a uma consulta sobre a aplicação do direito europeu, decidiu que: (i) as regras do direito comunitário europeu sobre cartéis devem ser interpretadas de modo a não impedirem uma pessoa que tenha sofrido danos e que deseje obter indenização de ter acesso aos documentos relacionados a um acordo de leniência; e

\footnotetext{
${ }^{359}$ Sobre o assunto, GIANNI DE STEFANO escreve: “(...) public and private enforcement represent different sides of the same coin of antitrust enforcement: it is not 'either/or", but 'both'. However, the interplay between public and private enforcement becomes delicate when dealing with the issue of access to evidence by alleged cartel victims claiming damages. While damage claimants seek to obtain evidence of the cartel to prove their case (e.g. damage quantification) before a national judge, the position of public enforcers is that evidence should not be disclosed to claimants when this would undermine other interests such as the professional secrets of companies involved in a cartel or the incentives for companies to co-operate with the public antitrust enforcers" ("Access of Damage Claimants to Evidence Arising Out of EU Cartel Investigations: A Fast-Evolving Scenario", in Global Competition Litigation Review, vol. 3, 2012, p. 95).
} 
(ii) no entanto, cabem aos juízes e tribunais de cada Estado Membro, com base na legislação nacional, decidirem sobre a possibilidade de concessão de acesso aos documentos oriundos de acordos de leniência, sopesando no caso concreto os interesses protegidos pelo direito comunitário europeu ${ }^{360-361}$.

No intuito de eliminar as incertezas sobre o tema criadas (ou explicitadas) pelo "Caso Pfleiderer" ${ }^{362}$, a Diretiva aprovada na União Europeia, que estabelece regras a serem adotadas pelos Estados Membros com relação à reparação de danos oriundos de práticas anticompetitivas, procurou regular a matéria.

Conforme analisado no capítulo 4, a Diretiva determina que a legislação dos Estados Membros deverá assegurar a possibilidade de os prejudicados terem acesso a informações e documentos que estejam na posse dos réus e de terceiros (incluindo autoridades concorrenciais), desde que os prejudicados apresentem justificativa razoável quanto à plausibilidade do pleito indenizatório (artigo 5). Especificamente com relação aos pedidos de acesso aos documentos incluídos no âmbito de procedimentos em curso perante

\footnotetext{
${ }^{360}$ Veja-se o dispositivo da decisão: The provisions of European Union law on cartels, and in particular Council Regulation (EC) No 1/2003 of 16 December 2002 on the implementation of the rules on competition laid down in Articles 101 TFEU and 102 TFEU, must be interpreted as not precluding a person who has been adversely affected by an infringement of European Union competition law and is seeking to obtain damages from being granted access to documents relating to a leniency procedure involving the perpetrator of that infringement. It is, however, for the courts and tribunals of the Member States, on the basis of their national law, to determine the conditions under which such access must be permitted or refused by weighing the interests protected by European Union law" (Processo C-360/09, Pfleiderer AG v. Bundeskartellamt, julgado em 14.06.2011, disponível em: <http://eur-lex.europa.eu/legalcontent/EN/TXT/PDF/?uri=CELEX:62009CJ0360\&from=EN>. Acesso em: 22.out.2014).

${ }^{361}$ De acordo com LAURENCE IDOT e FABIEN ZIVY, a decisão é ilustrativa da necessidade de articulação entre o enforcement público e o enforcement privado diante da tensão entre a proteção da eficácia dos programas de leniência e a necessidade de efetivação do direito à reparação dos prejuízos consagrado nos precedentes Courage e Manfredi, acima mencionados ("L'accès au Dossier des Autorités de Concurrence dans le Cadre des Actions Privées: État des Lieux Deux Ans Après l'arrêt Pfleiderer", in Concurrences - Revue des Droits de la Concurrence, n. 3, 2013, disponível em: $<$ http://www.concurrences.com/spip.php?action=acceder_document\&arg=19467\&cle=01d79932dee7715180 e0719afaaa93547157a7b8\&file=pdf\%2F05a.concurrences_3-2013_doctrines_1._idot.pdf $>$. Acesso em: 31.out.2014, pp. 34-35).

362 "The Pfleiderer judgment created uncertainty over whether national courts could take a consistent approach as to the disclosure of leniency materials" (RICHARD PIKE e FRANCESCA RICHMOND, "Disclosure of Leniency Materials by EU Competition Authorities: Protection in the Face of Civil Damages Claims", in Global Competition Litigation Review, disponível em: <http://www.algoodbody.ie/media/GlobalCompLitigationReview1.pdf>. Acesso em: 31.out.2014, p. 137).
} 
autoridades concorrenciais, a Diretiva estabelece critérios específicos para a análise da proporcionalidade do pedido ${ }^{363}$.

De modo a não prejudicar o andamento das investigações pelas autoridades de defesa da concorrência, a Diretiva estabelece no artigo 6, item 5, que determinados documentos somente poderão ser disponibilizados após o encerramento das investigações, tais como informações que tenham sido preparadas pelas partes ou terceiros especificamente para o procedimento em curso perante a autoridade concorrencial (por exemplo, defesas e depoimentos escritos de testemunhas) e informações que a autoridade concorrencial tenha redigido e enviado às partes no curso do procedimento (por exemplo, notas técnicas confidenciais contendo resumo dos fatos investigados e das evidências). Essa regra deve ser lida em conjunto com o artigo 10, item 4, da Diretiva que, conforme analisado no capítulo 4, estabelece que o prazo prescricional do pleito indenizatório deverá ser interrompido ou suspenso na pendência de investigação por parte de autoridade concorrencial. Desse modo, a disponibilização de determinadas informações somente após o encerramento das investigações não acarreta o risco de a pretensão indenizatória prescrever antes que os prejudicados possam ter acesso aos documentos.

Por outro lado, como forma de preservar os incentivos ao programa de leniência, a Diretiva prevê que as confissões emitidas pelos réus no âmbito de acordos de leniência e de propostas de transação não poderão ser disponibilizadas como prova no âmbito de ações de indenização (artigo 60 $6^{\circ}$ item 6) ${ }^{364}$.

\footnotetext{
363 A Diretiva prevê que, na análise da proporcionalidade de eventual ordem de disponibilização dos documentos, os tribunais dos Estados Membros devem levar em conta determinados critérios, tais como: (a) se o pedido foi formulado especificamente com relação ao objeto, natureza e conteúdo dos documentos apresentados à autoridade concorrencial ou incluídos no processo administrativo instaurado por essa autoridade, ou se o pedido for genérico; (b) se a parte que solicitou o acesso aos documentos está formulando o pedido no âmbito de uma ação de indenização perante um tribunal nacional; e (c) a eventual necessidade de resguardar a efetividade da aplicação do direito da concorrência por autoridades públicas (artigo $6^{\circ}$ ).

364 “Article 6 (...) 6. Member States shall ensure that, for the purpose of actions for damages, national courts cannot at any time order a party or third party to disclose any of the following categories of evidence: (a) leniency statements; and (b) settlement submissions". A Diretiva define "leniency statement" da seguinte forma: "leniency statement' means an oral or written presentation voluntarily provided by, or on behalf of, an undertaking or a natural person to a competition authority or a record thereof, describing the knowledge of that undertaking or natural person of a cartel and describing its role therein, which presentation was drawn up specifically for submission to the competition authority with a view to obtaining immunity or a reduction of fines under a leniency programme, not including pre-existing information" (artigo $2^{\circ}$, item 16 da Diretiva).
} 
A exposição de motivos que acompanha a Diretiva apresenta as seguintes justificativas para as regras propostas sobre o assunto:

\begin{abstract}
"Leniency programmes and settlement procedures are important tools for the public enforcement of Union competition law as they contribute to the detection, the efficient prosecution and the imposition of penalties for the most serious competition law infringements. Furthermore, as many decisions of competition authorities in cartel cases are based on a leniency application and damages actions in cartel cases are generally follow-on actions, leniency programmes are equally important for effective actions for damages in cartel cases. Undertakings may be deterred from co-operating in this context if self-incriminating statements such as leniency statements and settlement submissions, which are solely produced for the purpose of such cooperation, were disclosed. Such disclosure poses a risk of exposing cooperating undertakings or their managing staff to civil or criminal liability under worse conditions than the co-infringers that do not co-operate with competition authorities. To ensure the undertakings' continued willingness to voluntarily approach competition authorities with leniency statements or settlement submissions, such documents should be excepted from disclosure of evidence. The exception from disclosure should also apply to literal quotations of a leniency statement or a settlement submission in other documents. The limitations on the disclosure of evidence should not prevent competition authorities from publishing their decisions in accordance with applicable Union or national rules. In order to ensure that this complete exception from disclosure does not unduly interfere with the injured parties' right to compensation, it should be limited to these voluntary and selfincriminating leniency statements and settlement submissions".
\end{abstract}

Nesse sentido, a Diretiva procurou atingir um equilíbrio entre os dois valores acima descritos - reparação dos prejuízos e preservação dos incentivos à leniência - eis que: (i) a Diretiva possibilita, sob certas condições, o acesso dos prejudicados aos documentos incluídos nos procedimentos em curso perante autoridades concorrenciais (incluindo as evidências entregues às autoridades por signatários de acordos de leniência); e (ii) ao mesmo tempo, veda o acesso às confissões e demais declarações auto incriminadoras prestadas voluntariamente pelos beneficiários do acordo de leniência, para evitar que estes se vejam em posição mais desvantajosa do que os demais membros do cartel com relação às ações indenizatórias.

No Brasil, esse tema também tem sido objeto de discussão na jurisprudência recente. Para compreensão da questão, deve-se em primeiro lugar esclarecer que, de modo geral, os documentos sigilosos constantes de processos administrativos em trâmite no CADE (por exemplo, documentos contendo sigilo fiscal ou bancário, segredos de empresa ou indústria, dentre outros), são juntados em autos de acesso restrito que, em regra, ficam 
disponíveis apenas à parte que apresentou os documentos, aos representados no processo administrativo e às pessoas autorizadas pelo $\mathrm{CADE}^{365}$.

Desse modo, caso os autores de ações indenizatórias desejem ter acesso aos documentos constantes dos autos restritos do processo administrativo em trâmite no CADE, devem solicitar ao juiz da ação indenizatória que envie ofício ao CADE determinando a disponibilização de tais documentos. Esses pedidos costumam ser objeto de análise caso a caso pelos respectivos juízes das ações indenizatórias, que avaliam a real necessidade de juntada dos documentos como prova emprestada e, em muitos casos, costumam deferir o pedido e determinar que o CADE seja oficiado para remeter as cópias do processo administrativo ${ }^{366}$.

No caso específico de declarações e documentos disponibilizados por beneficiários de acordos de leniência, a análise da questão é mais complexa, pois a Lei 12.529/2011 e o Regimento Interno do CADE conferem tratamento sigiloso a tais documentos e declarações.

Com efeito, o artigo 86, $\S 9^{\circ}$ da Lei 12.529/2011 assegura tratamento sigiloso à proposta de acordo de leniência, nos seguintes termos: "considera-se sigilosa a proposta de acordo de que trata este artigo, salvo no interesse das investigações e do processo administrativo". No mesmo sentido, o artigo 49 da Lei 12.529/2011 estabelece que "o Tribunal e a Superintendência-Geral assegurarão nos procedimentos previstos nos incisos II, III, IV e VI do caput do art. 48 desta Lei o tratamento sigiloso de documentos,

\footnotetext{
${ }^{365}$ Veja-se o teor do artigo 50 do Regimento Interno do CADE: “Art. 50. Aos autos, informações, dados, correspondências, objetos e documentos de interesse de qualquer das diversas espécies de procedimento administrativo, serão conferidos, no Cade, os seguintes tratamentos: I - público, quando puderem ser acessados por qualquer pessoa; II - acesso restrito, quando seu acesso for exclusivo à parte que os apresentou, aos Representados, conforme o caso, e às pessoas autorizadas pelo Cade; III - sigiloso, quando seu acesso for exclusivo às pessoas autorizadas pelo Cade e às autoridades públicas responsáveis por proferir parecer ou decisão; ou IV - segredo de justiça, com acesso limitado nos termos de decisão judicial".

${ }^{366}$ A título de exemplo, veja-se a decisão proferida no âmbito de ação civil pública ajuizada pelo Ministério Público em Campinas referente ao processo administrativo que investigou a existência de cartel no mercado de gases industriais, na qual foi proferida decisão em primeira instância determinando que "deverá o CADE juntar cópia integral do processo administrativo, cujos documentos deverão ser trazidos em volumes apartados" (Processo n ${ }^{\circ}$ 0002983-48.2012.4.03.6105, $6^{\mathrm{a}}$ Vara Federal de Campinas-SP). O próprio CADE, no julgamento de processo administrativo em questão, emitiu opinião segundo a qual "recomenda-se ao Poder Judiciário a publicação dos documentos e degravações obtidas no início da instrução penal. Passaram-se mais de seis anos da obtenção inicial desses elementos. Eles não possuem mais valor empresarial de relevo, não havendo prejuízo em sua divulgação" (Processo Administrativo no 08012.009888/2003-70, Conselheiro Relator Fernando de Magalhães Furlan, julgado em 01.09.2010).
} 
informações e atos processuais necessários à elucidação dos fatos ou exigidos pelo interesse da sociedade".

Por sua vez, o Regimento Interno do CADE estabelece que "a proposta de acordo de leniência receberá tratamento sigiloso" (artigo 200). Além disso, o Regimento Interno é expresso ao dispor que o acesso pelos demais investigados ao acordo de leniência, seus anexos e documentos disponibilizados pelo beneficiário se dá "estritamente para fins de exercício do direito ao contraditório e da ampla defesa" (art. 207, § $2^{\circ}$, inc. I), sendo "vedada a divulgação ou o compartilhamento, total ou parcial, com outras pessoas físicas, jurídicas ou entes de outras jurisdições, do acordo de leniência e de seus anexos, bem como de quaisquer documentos apresentados pelo signatário do acordo de leniência ou que recebam tratamento de acesso restrito por parte do Cade, sendo que a desobediência desse dever sujeitará os infratores à responsabilização administrativa, civil e penal" (art. $207, \S 2^{\circ}$, inc. II).

$\mathrm{Na}$ jurisprudência recente, a possibilidade de acesso aos documentos relacionados ao acordo de leniência foi abordada no âmbito do processo administrativo que tem por objeto suposto cartel em licitações para aquisições de trens e construções de linhas de metrô no Estado de São Paulo. Após a divulgação pela imprensa de que estava em curso investigação do suposto cartel, iniciada após acordo de leniência celebrado pela empresa Siemens, o Estado de São Paulo pleiteou acesso aos documentos com o objetivo de viabilizar a propositura de ação indenizatória para reparação dos prejuízos advindos do cartel.

O Estado de São Paulo inicialmente propôs mandado de segurança com o objetivo de ter acesso à documentação, no âmbito do qual foi negada a liminar pelo juízo da $2^{\text {a }}$ Vara Federal da Seção Judiciária do Distrito Federal. A decisão levou em conta o sigilo conferido aos documentos pela Lei 12.529/2011 e, embora tenha admitido a possibilidade de "certa mitigação do princípio, especialmente quando se tratar de transferência de dados dentro da Administração Pública", entendeu que o acesso não deveria ser deferido em sede de medida liminar ${ }^{367}$. Tal decisão foi confirmada pelo

367 "Por outro lado, noto que o sigilo, em princípio, tem amparo legal, conforme o art. 49 da Lei 12.529/2011. É certo que se pode até admitir certa mitigação do princípio quando se tratar de transferência de dados dentro da própria Administração Pública. Entretanto, isso não deve ser feito em mera medida liminar, uma vez que 
Tribunal Regional Federal da $1^{\text {a }}$ Região, por decisão monocrática proferida pelo relator do agravo de instrumento interposto pelo Estado de São Paulo ${ }^{368}$.

Posteriormente, o Estado de São Paulo apresentou requerimento de acesso aos documentos no âmbito da ação de busca e apreensão ajuizada pelo CADE para obtenção de evidências do cartel nas sedes das empresas investigadas. O juízo da $4^{\mathrm{a}}$ Vara Cível da Seção Judiciária de São Paulo proferiu decisão autorizando o acesso do Estado de São Paulo à documentação, inclusive aos documentos relacionados ao acordo de leniência, nos seguintes termos ${ }^{369}$ :

"Inicialmente, cumpre ressaltar que o $9^{\circ}$, do artigo 86 , da Lei $12.529 / 11$,
determina o sigilo da proposta de acordo referente ao programa de leniência,
salvo no interesse das investigações e do processo administrativo.
Entretanto, no caso concreto, considero que o próprio CADE relativizou o
sigilo do acordo tratado nestes autos, já que, em 16/08/2013, divulgou nota
de seguinte teor em seu sítio na internet: (...). Portanto, por meio das
notícias acima veiculadas, percebe-se a intenção do CADE de tornar
conhecida do público a atividade por ele desenvolvida.
Neste passo, entendo ser notável a atitude da Autarquia devido ao interesse
público que permeia a situação em concreto. Justifica-se o interesse público,
principalmente, no poder-dever tanto da entidade autárquica, quanto dos
demais entes estatais (Ministério Público Federal e do Estado, bem como da
própria Administração Direta - Estado de São Paulo) de fiscalizar e punir
condutas nocivas ao erário. Quanto ao Estado de São Paulo é legítimo seu
interesse em ver apurados os fatos, inclusive em seara administrativa, para
fins de punição dos responsáveis, ajuizamento de eventuais ações de
improbidade e ressarcimento dos prejuízos causados pelos envolvidos.
Assim, demonstra-se o interesse, até mesmo jurídico, do Estado de São
Paulo de ter acesso aos autos e aos documentos apreendidos. Portanto, defiro
o pedido do Estado de São Paulo para que lhe seja facultada vista dos autos
para extração de cópias e dos documentos apreendidos, com a ressalva de
que deverá guardar sigilo dos documentos e informações a que tiver acesso".

satisfativa, e nem quando se tem o quadro ora traçado: o CADE não negou propriamente o acesso do Estado aos documentos. Na verdade, o que o CADE está fazendo é analisando a documentação, para aí, sim, poder verificar o que deve ser mantido em sigilo, ou não. (...) Ante o exposto, indefiro o pedido liminar" (Processo no 41875-13-65.2013.4.01.3400, $2^{\mathrm{a}}$ Vara Federal da Seção Judiciária do Distrito Federal, Juiz Federal Gabriel José Queiroz Neto, decisão proferida em 05.08.2013).

368 TRF-1, Agravo De Instrumento no 0045454-81.2013.4.01.0000/DF (d), Relator Desembargador Federal Kassio Nunes Marques, decisão publicada no EDJF-1 em 16.08.2013. O Estado de São Paulo posteriormente desistiu do mandado de segurança: "Desta feita, homologo o pedido de desistência ora formulado, para os efeitos do artigo 158, parágrafo único, do Código de Processo Civil, e declaro extingo o processo sem resolução de mérito com fulcro no artigo 267, VIII, do mesmo diploma legal" (Processo $\mathrm{n}^{\circ}$ 41875-1365.2013.4.01.3400, $2^{\mathrm{a}}$ Vara Federal da Seção Judiciária do Distrito Federal, Juiz Federal Gabriel José Queiroz Neto, decisão proferida em 11.11.2013).

${ }^{369}$ Processo no 0010939-96.2013.4.03.6100, 4 ${ }^{\text {a }}$ Vara Federal Cível da Subseção Judiciária de São Paulo - SP, decisão publicada no Diário Eletrônico em 06.09.2013. 
Posteriormente, o Juízo Federal de São Bernardo do Campo, nos autos de ação de busca e apreensão movida pelo CADE contra outra empresa investigada pelo mesmo cartel, também concedeu acesso ao CADE aos documentos dos autos, inclusive aos documentos relacionados ao acordo de leniência, considerando que "o próprio artigo 86, $9^{\circ}$, da Lei ${ }^{\circ} 12.529 / 2011$ ressalva a possibilidade de que o acordo de leniência deixe de ser sigiloso 'no interesse das investigações', exceção que, embora destinada à autoridade administrativa, revela a possibilidade de publicizar a proposta, principalmente quando os fatos extravasam as infrações à ordem econômica e acabam por refletir noutras searas de interesse persecutório de toda a sociedade" ${ }^{370}$.

As informações e documentos obtidos serviram para instruir a ação indenizatória movida pelo Estado de São Paulo contra a Siemens pleiteando o

\footnotetext{
370 "O ente federado ESTADO DE SÃO PAULO interveio às fls. 1195/1199, para requerer que seja facultada vista dos presentes autos para extração de cópias, com a ressalva de que o Estado guardará o sigilo legal dos documentos que assim o exigirem. Alega, em suma, que, como legitimado ao ajuizamento de ação de ressarcimento de danos, improbidade administrativa e outras medidas acautelatórias, busca conferir maior celeridade às apurações devidas e obter documentos essenciais para a ágil identificação de eventuais servidores públicos e agentes políticos envolvidos em conluios lesivos ao patrimônio público. Sustenta que o CADE negou acesso a qualquer documento que integra o referido inquérito administrativo, ora invocando o sigilo decorrente do acordo de leniência, ora invocando o segredo de justiça decretado em medidas cautelares ajuizadas pela autarquia. Esclarece que impetrou mandado de segurança distribuído na $2^{\mathrm{a}}$ Vara Federal do Distrito Federal e que, após indeferida a liminar, o CADE juntou petição naqueles autos, manifestando-se no sentido de que inexiste pretensão resistida e que compete ao juízo das medidas cautelares deferir o compartilhamento das provas obtidas. (...) No caso dos autos, colho do site do CADE (www.cade.gov.br) a notícia divulgada em 04/07/2013, com o título "Cade investiga cartel em licitações para aquisição de trens e construção de linhas de metrôs": (...) Ora, é evidente que, a partir dessa informação repassada ao público no que entendo que o CADE prestou contas de suas relevantes atividades -, o interesse social passa a predominar, inclusive em face das obrigações legais do Estado de controlar o acesso e a divulgação de informações sigilosas produzidas por seus órgãos e entidades (Lei $\left.n^{\circ} 12.527 / 2011\right)$. Decerto que a sociedade e, mais especificamente, o Estado de São Paulo e o Ministério Público Estadual, por exemplo, têm justificado interesse de ter acesso aos termos do acordo de leniência e demais documentos que acompanharam a petição inicial da medida cautelar, para aprofundamento das investigações e apurações cabíveis por parte dos competentes órgãos estatais. Em caso de eventuais crimes e atos de improbidade, por exemplo, os prazos prescricionais estão em pleno curso e já adiantados senão ultrapassados, justificando a urgência no acesso ao que consta dos autos judiciais. Além disso, o noticiário jornalístico tem divulgado, a todo instante, o nome da empresa SIEMENS e possível envolvimento de funcionários públicos de diversos escalões e figuras de renome do cenário político, com detalhes que escapam ao processo judicial, de modo que o restabelecimento do sigilo não alcançaria mais o fim desejado pelo CADE de preservar a identidade do leniente. Ao contrário, caso as informações repassadas sejam incompletas ou enviesadas, o segredo de justiça pode contribuir para denegrir a imagem de terceiros que sequer tenham envolvimento ou eventualmente dificultar a identificação de todos os reais participantes do esquema que poderá provar-se criminoso. O próprio artigo $86,9^{\circ}$, da Lei ${ }^{\circ}$ 12.529/2011 ressalva a possibilidade de que o acordo de leniência deixe de ser sigiloso "no interesse das investigações", exceção que, embora destinada à autoridade administrativa, revela a possibilidade de publicizar a proposta, principalmente quando os fatos extravasam as infrações à ordem econômica e acabam por refletir noutras searas de interesse persecutório de toda a sociedade" (Processo $\mathrm{n}^{\circ}$ 000419628.2013.4.03.6114, $3^{\mathrm{a}}$ Vara Federal Cível de São Bernardo do Campo - SP, decisão publicada no Diário Eletrônico em 13.08.2013).
} 
ressarcimento dos prejuízos oriundos do alegado cartel, a qual tramita em segredo de justiça perante a $4^{\mathrm{a}}$ Vara da Fazenda Pública da comarca de São Paulo - $\mathrm{SP}^{371}$.

Em síntese, o quadro normativo brasileiro não contém regra expressa disciplinando a interação entre o programa de leniência e as ações de indenização no tocante ao acesso aos documentos relacionados ao acordo de leniência. Por um lado, há normas assegurando o tratamento sigiloso da proposta de leniência no âmbito do processo administrativo, bem como proibindo os demais investigados de compartilharem os documentos e informações disponibilizados pelo signatário de leniência. De outro lado, não há qualquer norma que impeça ou estabeleça limites para que o Poder Judiciário determine ao CADE que dê acesso a esses documentos para fins de instrução das respectivas ações indenizatórias.

Na jurisprudência, como visto, há precedentes recentes admitindo o acesso a tais documentos em prol do interesse do Estado em ser ressarcido pelos prejuízos causados pelos cartéis. Por se tratar de matéria que apenas recentemente passou a ser objeto de análise pelo Poder Judiciário, não há jurisprudência consolidada sobre o tema.

\subsubsection{Inexistência de limitação à responsabilidade civil dos beneficiários da leniência}

Por fim, ainda no tocante à interação entre as ações indenizatórias e o programa de leniência, deve-se registrar que não há no direito brasileiro qualquer norma que atenue a responsabilidade civil dos beneficiários do acordo de leniência.

Conforme analisado no capítulo 4, nos Estados Unidos e na União Europeia, como forma de assegurar os incentivos à celebração de acordos de leniência, há normas que atenuam a responsabilidade civil dos signatários do acordo de leniência, que respondem no âmbito civil apenas pelos danos decorrentes das vendas de seus próprios produtos ou serviços com sobrepreço, sem precisar arcar solidariamente com os danos causados pelas vendas de produtos ou serviços dos demais membros do cartel.

\footnotetext{
371 Cf. notícia disponibilizada no endereço eletrônico da Procuradoria Geral do Estado de São Paulo, disponível em: <http://www.pge.sp.gov.br/visualizanoticia.aspx?id=2980>. Acesso em: 25.out.2014.
} 
Não há regra semelhante no direito brasileiro, de modo que o beneficiário do acordo de leniência poderá ser condenado a responder solidariamente por todo o prejuízo decorrente do cartel, nos termos do artigo 942 do Código Civil.

No capítulo 6 serão examinadas propostas de reforma do ordenamento jurídico brasileiro com o objetivo de disciplinar a questão da interação entre a responsabilidade civil e o programa de leniência.

\subsection{Prescrição da pretensão reparatória}

Este item examinará a prescrição da pretensão de reparação civil, tema que desperta importantes discussões com relação às demandas indenizatórias por prejuízos decorrentes da prática de cartel.

\subsubsection{Prazo e termo inicial da prescrição}

Nos termos do art. 206, $\S 3^{\circ}$, inc. V do Código Civil, a pretensão de reparação civil prescreve em 3 (três) anos. Com relação ao termo inicial do prazo prescricional, o art. 189 do Código Civil dispõe que "violado o direito, nasce para o titular a pretensão, a qual se extingue, pela prescrição, nos prazos a que aludem os arts. 205 e 206". Referido dispositivo consagra o princípio da "actio nata”, pelo qual a pretensão nasce com a violação do direito.

Interpretando referido dispositivo do Código Civil, há julgados do Superior Tribunal de Justiça que entendem que, como regra geral, o prazo prescricional tem início a partir da simples violação ao direito, independentemente de a vítima ter ou não ciência da violação e dos prejuízos resultantes. De acordo com essa linha jurisprudencial, o Código Civil seria expresso em todas as hipóteses em que o prazo começa a fluir a partir da ciência do dano, como ocorre, por exemplo, com relação à pretensão do segurado contra a seguradora; nos demais casos, o início da fluência do prazo prescricional independeria da ciência do dano por parte da vítima ${ }^{372}$.

\footnotetext{
${ }^{372}$ Veja, por exemplo, o seguinte julgado: "Em nosso direito, quando a lei pretende que o termo a quo seja o da ciência do fato, di-lo expressamente. Assim, o artigo 178, do Código Civil, em seus parágrafos $4^{\circ}$, I e II e $7^{\circ}$, V. As hipóteses são excepcionais, pela insegurança quais disposições podem acarretar para a estabilidade das relações" (STJ, Recurso Especial no 36334/SP, Rel. Ministro Eduardo Ribeiro, $3^{\mathrm{a}}$ Turma, julgado em
} 
Há outra corrente que defende que o prazo prescricional somente se inicia após a ciência do dano por parte do titular da pretensão. Na doutrina, JOSÉ FERNANDO SIMÃO defende que, em matéria de responsabilidade civil extracontratual, deve ser afastada a noção de "actio nata", iniciando-se o prazo prescricional a partir do efetivo conhecimento do dano. $\mathrm{O}$ autor se vale da distinção acima descrita entre dano-evento (violação do bem jurídico protegido) e dano-prejuízo (prejuízo patrimonial ou extrapatrimonial resultante da violação), esclarecendo que, em muitas situações, a ocorrência de dano-prejuízo nem sempre será conhecida pela vítima imediatamente após a ocorrência do dano-evento. Nas palavras do autor ${ }^{373}$ :

"Para fins de responsabilidade extracontratual, a noção de Savigny de actio nata deve ser afastada. Em se tratando de direito disponível no qual não houve negligência ou inércia do titular do direito que desconhecia a existência do próprio crédito e, portanto, a possibilidade do exercício da pretensão, o prazo prescricional só se inicia com o efetivo conhecimento. (...) A negligência supõe uma vontade que se omite, e a prescrição pode apagar relação jurídica de todo em todo ignorada pelo seu titular. Como falar-se de omissão de vontade por parte de quem sequer sabia que podia querer e agir?".

$\mathrm{Na}$ jurisprudência, em situações em que o lesado não teria condições de saber da existência da violação no momento de sua ocorrência, outros precedentes do Superior Tribunal de Justiça, manifestando entendimento diferente dos julgados mencionados acima, entenderam que o prazo prescricional somente se inicia após o titular do direito ter ciência de sua violação ${ }^{374}$.

No âmbito da responsabilidade civil por cartel, caso prevaleça o entendimento de que o prazo prescricional se inicia independentemente do conhecimento

14.09.1993, DJ 04.10.1993). Confira-se também um dos julgados mais recentes a defender esse posicionamento: "O art. 189 do CC/02 consagrou o princípio da actio nata, fixando como dies a quo para contagem do prazo prescricional a data em que nasce o direito subjetivo de ação por violação de direito, independentemente da efetiva ciência da vítima" (STJ, Recurso Especial n 1168336/RJ, Rel. Ministra Nancy Andrighi, $3^{\mathrm{a}}$ Turma, julgado em 22.03.2011).

${ }^{373}$ Prescrição e Decadência: Início dos Prazos, São Paulo, Atlas, 2013, pp. 213-214.

${ }^{374}$ Veja-se o seguinte julgado: "O termo a quo para auferir o lapso prescricional para ajuizamento de ação de indenização contra o Estado não é a data do acidente, mas aquela em que a vítima teve ciência inequívoca de sua invalidez e da extensão da incapacidade de que restou acometida." (STJ, Recurso Especial n 673576/RJ, Rel. Ministro José Delgado, 1ª Turma, julgado em 02.12.2004). 
do dano por parte da vítima, poderá restar prejudicada ou até mesmo inviabilizada a reparação dos prejuízos decorrentes do cartel.

Isso porque o cartel é uma infração cometida sob sigilo, de modo que, em geral, os adquirentes dos produtos ou serviços somente descobrem que foram lesados após a divulgação das investigações pelas autoridades de defesa da concorrência, o que, em muitos casos, ocorre anos depois do início do $\operatorname{cartel}^{375}$. Tendo em vista que o prazo de prescrição da pretensão de reparação civil é de apenas três anos, caso prevaleça a intepretação ora em discussão, é de se presumir que os prejudicados na maioria dos casos somente teriam ciência do cartel depois de transcorrido o prazo prescricional ${ }^{376}$.

Diante disso - e em linha com a segunda corrente doutrinária e jurisprudencial mencionada acima - entende-se que, para evitar que os infratores sejam beneficiados pela natureza sigilosa dos cartéis, a interpretação mais adequada em casos de cartel é aquela segundo a qual o prazo de prescrição somente se inicia após os prejudicados terem condições de ter ciência da prática ilícita ${ }^{377}$, o que geralmente ocorrerá após a divulgação das investigações iniciadas pelas autoridades concorrenciais.

Deve-se levar em conta que, além de atender ao interesse social da estabilidade das relações jurídicas, a prescrição representa um verdadeiro castigo à inércia do titular da pretensão ${ }^{378}$. Em assim sendo, não é razoável punir com a prescrição aquele

\footnotetext{
${ }^{375}$ Sobre o assunto, o Cade esclarece que "ainda é muito pouco difundida a compreensão de que o cartel é uma prática caracterizada por sigilo absoluto." (voto do Conselheiro Relator Fernando de Magalhães Furlan no processo administrativo $\mathrm{n}^{\circ}$ 08012.009888/2003-70, julgado em 01.09.2010).

${ }^{376} \mathrm{Na}$ doutrina nacional, "o prazo de prescrição relativamente curto e a ausência de definição do termo $a$ quo do início da contagem do prazo" são apontados como fatores que inibem a propositura de ações de reparação civil por danos decorrentes infrações à ordem econômica. Veja-se: "A regra geral do Código Civil a respeito da prescrição para a pretensão de reparação civil está prevista no artigo 206 , § $3^{\circ}$, inciso $\mathrm{V}$, que dispõe em 3 (três) anos o prazo. Dada as dificuldades, no âmbito de uma ação civil, de produção de prova de uma infração, seria natural que ações reparatórias individuais (ou individuais homogêneas) fossem ajuizadas após uma decisão condenatória do CADE. Ocorre que os processos administrativos no SBDC, em média, demoram mais do que 3 (três) anos para receberem um julgamento final do CADE, o que poderia gerar a extinção do direito de ação. Entretanto, outra discussão gira em torno exatamente do termo a quo do início da contagem do prazo, se seria da ocorrência do suposto dano, da instauração do processo administrativo ou da condenação final do CADE" (EduARdo CAMinati ANDERs, LEOPOLDO PAGOTTO e Vicente BAGNoli, Comentários à Nova Lei de Defesa da Concorrência ..., cit., p. 190).

377 No mesmo sentido: ANDRÉ MARQUES FranCiSCO, Responsabilidade Civil por Infração da Ordem Econômica, cit., p. 118.

${ }^{378}$ Nesse sentido, CARLOS AlBERTo DABUS MALUF: “(...) cumpre atender não só ao interesse individual, mas também e principalmente ao interesse social; se o proprietário se descura das terras que lhe pertencem, da qual se apossa um usurpador, não procurando reavê-las, sua inação só pode ser entendida como verdadeira
} 
que, dado o caráter sigiloso da violação de que foi vítima, não teria condições de ter ciência imediata da prática. Trata-se, portanto, da interpretação mais razoável tendo em vista as especificidades da prática de cartel.

Como visto acima, essa é a regra vigente no direito norte-americano, sendo também a regra estabelecida pela Diretiva aprovada na União Europeia com o objetivo de uniformizar a disciplina da matéria no direito comunitário europeu.

Esse tema será analisado novamente no capítulo 6, que examinará propostas de reforma do ordenamento jurídico brasileiro com relação à responsabilidade civil pela prática de cartel.

Note-se, por fim, que caso a demanda seja ajuizada para pleitear prejuízos sofridos por consumidores - diretamente ou mediante substituição processual em sede de tutela coletiva -, será possível sustentar a aplicação da regra contida no art. 27 do Código de Defesa do Consumidor, que prevê prazo prescricional de cinco anos e dispõe expressamente que a fluência do prazo somente se inicia a partir do conhecimento do dano e de sua autoria ${ }^{379}$.

\subsubsection{Início do prazo prescricional caso a prática também constitua crime: artigo 200 do Código Civil}

Ainda com relação ao tema da prescrição, deve-se registrar que, nos termos do art. 200 do Código Civil, "quando a ação se originar de fato que deva ser apurado no juízo criminal, não correrá a prescrição antes da respectiva sentença definitiva". O dispositivo em questão prevê uma causa impeditiva da prescrição, de modo que não correrá o prazo prescricional quando o fato que originou o pedido indenizatório também constituir crime $^{380}$.

renúncia de direitos. A prescrição surgirá como castigo à sua inércia. É natural venha ele a perder o que não soube conservar, nem defender, em benefício daquele que teve iniciativa e valorizou o imóvel com seu labor" (Código Civil Comentado - Prescrição, Decadência e Prova, vol. 3, São Paulo, Atlas, 2009, p. 8).

${ }^{379}$ Nesse sentido: "The time limit for such lawsuits is three years for injured parties in general and five years if the victim is a consumer, counted from the date the damage has occurred" (CARLOS FRANCISCO DE Magalhães, Gabriel Nogueira Dias e Cristiano Rodrigo DEl DeBbio, “Brazil”, cit., p. 23).

380 CAIO MÁRIO DA SILVA PEREIRA esclarece que "embora a responsabilidade civil seja independente da criminal (v. art. 935), a pendência de processo criminal suspende o curso da ação fundada em fato que deva 
Como adiantado no capítulo 2, a prática de cartel também constitui crime, razão pela qual é possível sustentar a aplicação do artigo 200 do Código Civil no âmbito da responsabilidade civil por danos decorrentes da prática de cartel.

Uma questão que se coloca é se referido dispositivo é aplicável às hipóteses em que, embora o fato seja penalmente típico, não tenha sido ajuizada ação penal. Com relação a essa situação, há dois entendimentos distintos:

i) o primeiro entendimento sustenta que, caso o fato não seja objeto de ação penal, a causa impeditiva da fluência do prazo prescricional prevista no artigo 200 do Código Civil não é aplicável ${ }^{381}$; e

ii) o segundo entendimento preconiza que, caso o fato seja penalmente típico mas não seja objeto de ação penal, a prescrição civil somente tem início quando se consumar a prescrição da pretensão punitiva no âmbito penal ${ }^{382}$.

Embora o segundo entendimento tenha o mérito de conferir maior previsibilidade à aplicação do artigo 200 do Código Civil - evitando que sua incidência fique dependente de um fato incerto posterior ao início do prazo prescricional, qual seja, a eventual propositura de ação penal - a posição manifestada pelo Superior Tribunal em julgado recente é mais próxima do primeiro entendimento. De acordo com tal posição, a causa impeditiva do prazo prescricional prevista no artigo 200 do Código Civil somente

ser apurado no juízo criminal, porque seria ela dependente de seu desfecho. Várias situações previstas como delito criminal têm por efeito ressarcimento no juízo cível. A própria sentença penal condenatória constitui título hábil para que se promova a execução. Conseguintemente não corre prescrição até esse momento" (Instituições de Direito Civil, cit., p. 698).

${ }^{381}$ De acordo com RUI STOCO, “a disposição do art. 200 só terá incidência e efícácia e, somente então, o prazo prescricional será suspenso, apenas se a ação penal, pública ou privada, for efetivamente ajuizada" (Tratado de Responsabilidade Civil..., cit., p. 209).

${ }^{382}$ Nesse sentido, veja-se o entendimento de MARCELO VIEIRA VON ADAMEK: "Entendemos que, conquanto obscura e imprecisa, a regra do art. 200, do CC de 2002, contempla uma causa impeditiva da prescrição, a ser aplicada da seguinte forma: (i) havendo processo-crime pendente, o prazo civil só se iniciará com o trânsito em julgado da sentença penal, qualquer que seja o seu resultado; e (ii) não havendo processo-crime proposto, mas sendo o fato típico, a prescrição civil iniciar-se-á a partir do momento em que vier a se consumar a prescrição da pretensão punitiva penal (CP, art. 109) ou desde quando sobrevenha fato apto a determinar a extinção da punibilidade, a paralisação definitiva da investigação penal ou, ainda, a própria morte do agente" (Responsabilidade Civil dos Administradores de S/A e as Ações Correlatas, São Paulo, Saraiva, 2010, p. 301). 
será aplicável caso haja ação penal ou, ao menos inquérito policial em curso; na hipótese de o prazo prescricional na esfera cível se consumar sem que tenha sido proposta ação penal ou inquérito policial, o artigo 200 do Código Civil não pode ser invocado para afastar a prescrição ${ }^{383}$.

${ }^{383}$ Confira-se o entendimento manifestado pelo STJ: "A finalidade dessa norma é evitar a possibilidade de soluções contraditórias entre os juízos cível e criminal, especialmente quando a solução do processo penal seja determinante do resultado processo cível. Por isso, permite-se à vítima aguardar a solução da ação penal para apenas depois desencadear a demanda indenizatória na esfera cível. De todo modo, é fundamental que exista processo penal em curso ou, pelo menos, a tramitação de inquérito penal policial até seu arquivamento" (REsp 1180237/MT, Rel. Ministro Paulo de Tarso Sanseverino, $3^{\mathrm{a}}$ Turma, julgado em 19.06.2012, DJe 22.06.2012). 


\section{ANÁliSE DE PROPOSTAS DE REFORMA DO ORDENAMENTO JURÍDICO BRASILEIRO}

Com base no estudo do direito estrangeiro e da doutrina brasileira empreendido nos capítulos precedentes, foi possível identificar algumas propostas de lege ferenda para aperfeiçoamento do sistema de responsabilidade civil por danos decorrentes do cartel no direito brasileiro. Este capítulo tem por objetivo analisar a conveniência e a viabilidade da adoção dessas propostas de reforma do ordenamento jurídico brasileiro.

\subsection{Análise da proposta de adoção de um fator multiplicador da indenização como forma de desestimular a prática de cartel}

Uma das propostas de reforma do ordenamento jurídico brasileiro no tocante à responsabilidade civil por danos decorrentes do cartel é a introdução de um fator multiplicador da indenização como forma de desestimular a prática de cartel. Essa proposta tem inspiração no sistema norte-americano, no qual, conforme estudado no capítulo 4, os prejudicados pela prática de cartel têm direito a receber um valor equivalente ao triplo dos prejuízos sofridos ( "treble damages”).

Argumenta-se, na linha dos defensores da regra de treble damages norteamericana (conforme discutido no capítulo 4), que a introdução de um fator multiplicador serviria como importante elemento de desestímulo à prática de cartel no Brasil.

Nesse sentido, Roberto Augusto CAStellanos Pfeiffer propõe a adoção no direito brasileiro de regra segundo a qual os prejudicados teriam direito a receber valor equivalente ao dobro do prejuízo sofrido, regra que, segundo o autor, deveria ser aplicada apenas nos casos de cartel, reconhecida como a mais grave infração à ordem econômica ${ }^{384}$.

384 "Entendo que seria conveniente introduzir um sistema de indenização multiplicada no Brasil, como forma
de incentivar as ações de reparação de danos ocasionados por infraços contra a ordem econômica. O sistema
é apto a gerar dois efeitos importantes para conferir maior efetividade à defesa da concorrência no Brasil: 1)
desestimular a prática de condutas anticoncorrenciais, pois as empresas correm o risco não somente de
receber sanções administrativas pecuniárias, mas também ter que arcar com elevado valor de indenização; 2)
permitir uma melhor percepção dos benefícios da defesa da concorrência, já que os agentes lesados poderão
ter a efetiva reparação de seus danos. No entanto, seja pelas peculiaridades de nosso ordenamento jurídico
(que praticamente não possui exemplos de indenizações com caráter punitivo), seja pelo amplo debate
suscitado nos Estados Unidos acerca de possíveis efeitos colaterais do sistema dos treble damages, parece
mais prudente introduzir paulatinamente o fator multiplicador no Brasil. Inicialmente, ele poderia ser 
Em sentido semelhante, a minuta de projeto de lei elaborada em 2011 pela SDE, órgão então responsável pela investigação de cartéis no Brasil, previa alteração na redação do art. 29 da lei concorrencial anterior, que passaria a prever que "os prejudicados terão direito ao ressarcimento em dobro pelos prejuízos sofridos em razão de infrações à ordem econômica, sem prejuízo das eventuais sanções aplicadas na esfera administrativa e penal" 385 .

A sugestão de introdução de um fator multiplicador da indenização em casos de cartel vai ao encontro do posicionamento de autores que, em matéria de responsabilidade civil, defendem a reforma do ordenamento jurídico brasileiro de modo a conferir uma função punitiva à responsabilidade civil, de modo análogo aos "punitive damages" adotados em outros países ${ }^{386}$.

Merece destaque o posicionamento de ANTONio JunQueIRA DE AZEVEDo, que defende a existência de uma nova categoria de dano no direito atual, o chamado "dano social”, o qual seria distinto do dano patrimonial e do dano moral e admitiria, para aqueles atos que atingem toda a sociedade, "num rebaixamento imediato do nível de vida da população", a fixação de indenização em caráter punitivo ou dissuasório, que reverteria em benefício da vítima (e não a um fundo estatal) ${ }^{387}$.

limitado ao dobro do valor do dano causado e apenas incidir em relação à conduta de cartel, que é reconhecida como a mais grave das infrações contra a ordem econômica. E, obviamente, tal multiplicação não seria aplicável à empresa que participou com sucesso do programa de leniência, a fim de que não fosse desestimulado o ingresso em tal programa. (...) A introdução paulatina do fator multiplicador permitiria observar os seus resultados para posteriormente avaliar-se a pertinência de sua ampliação a outras hipóteses" (Defesa da Concorrência e Bem-Estar do Consumidor, cit., pp. 268-269).

${ }^{385}$ Consulta Pública da Secretaria de Direito Econômico do Ministério da Justiça no 17/2011, disponível em: <http://www.cade.gov.br/upload/consulta17_2011.pdf>. Acesso em: 13.nov.2014. Com a entrada em vigor da nova lei concorrencial e a extinção da SDE, a minuta acabou não se convertendo em projeto de lei.

386 Sobre o assunto, ver: DANIEL DE ANDRADE LEVy, Responsabilidade Civil..., cit., pp. 255-260; PEDRO RICARDo E SERPA, Indenização Punitiva, cit., pp. 360-369; e NELSON RosenVALD, As Funções da Responsabilidade Civil..., cit., pp. 139-224.

${ }^{387}$ Nas palavras do autor, “um ato, se doloso ou gravemente culposo, ou se negativamente exemplar, não é lesivo somente ao patrimônio material ou moral da vítima, mas sim, atinge a toda a sociedade, num rebaixamento imediato do nível de vida da população. Causa dano social. Isto é particularmente evidente quando se trata da segurança, que traz diminuição da tranquilidade social, ou de quebra da confiança, em situações contratuais ou paracontratuais, que acarreta redução da qualidade coletiva de vida. (...) Os danos sociais, em tese, poderiam ir para um fundo como ressarcimento à sociedade, mas aí deveria ser por ação dos órgãos da sociedade como o Ministério Público. As condições concretas que vivemos não são, porém, favoráveis à criação de mais deveres para o Estado. É irrealismo; o Ministério Público já tem trabalho suficiente. Aqui, no caso, estamos, pois, entendendo que o particular, na sua ação individual de responsabilidade civil, age também como defensor da sociedade. Exerce um munus público que alguns 
Não concordamos com a sugestão, embora seja defendida por nomes ilustres. Entendemos que a introdução de um fator multiplicador das indenizações por cartel no direito brasileiro - com a possibilidade de condenação em valor mais elevado do que os danos patrimoniais sofridos - não seria desejável.

No exame do tema, deve-se ter em mente que, no direito concorrencial brasileiro, a função de prevenção e punição condutas anticompetitivas já é exercida primordialmente pelo CADE, que, conforme estudado no capítulo 2, tem competência para aplicar multas significativas na esfera administrativa.

Concordamos nesse ponto com a posição de ANDERSON SCHREIBER que, ao se manifestar contrariamente à introdução dos chamados "punitive damages" no direito brasileiro, sustenta que o estabelecimento de sanções na esfera administrativa - como, diga-se, já ocorre no âmbito do direito concorrencial - constitui medida mais adequada para desestimular práticas ilícitas ${ }^{388}$.

autores americanos, a respeito da mesma situação nos 'punitive damages', denominam 'private attorney general'. O autor, vítima, que move a ação, age também como um 'promotor público privado' e, por isso, merece a recompensa. Embora esse ponto não seja facilmente aceito no quadro da mentalidade jurídica brasileira, parece-nos que é preciso recompensar, e estimular, aquele que, embora por interesse próprio, age em benefício da sociedade. Trata-se de incentivo para um aperfeiçoamento geral. Conforme todo o exposto, estamos defendendo uma nova categoria de dano na responsabilidade civil: o dano social. (...) Poderá haver: a) o dano patrimonial individual, a ser fixado com os dados dos danos emergentes e dos lucros cessantes; b) o dano moral individual como compensação, determinada basicamente por arbitramento; e c) o dano social, ou como punição, por ter o autor agido com dolo ou culpa grave, ou como dissuasão, para não levar à repetição, pelo agente ou por outros, dos mesmos atos. A indenização, qualquer que seja, deverá ser entregue à própria vítima" ("Por uma Nova Categoria de Dano na Responsabilidade Civil: O Dano Social", cit., pp. 380-384).

388 “A incorporação dos punitive damages pela prática judicial brasileira traz, ainda, consideráveis inconsistência face ao princípio de proibição ao enriquecimento sem causa - já que a quantia paga a título de punição vem, inexplicavelmente, atribuída à vítima -, além de ferir frontalmente a dicotomia entre ilícito civil e ilícito penal, aplicando penas sem balizamento legal, sem as garantias processuais próprias e sem a necessária tipificação prévia das condutas reprováveis. Por fim, a indenização punitiva não raro se mostra ineficaz em seu próprio intuito, uma vez que 'na responsabilidade civil, nem sempre o responsável é o culpado e nem sempre o culpado será punido (porque ele pode ter feito um seguro)’ (...) Existem, claro, situações de 'microlesões' existenciais provocadas por conduta maliciosa e repetitiva, onde a soma global das indenizações compensatórias 'não justifica', em termos econômicos, a adoção de um procedimento mais probo por parte do ofensor. Em tais hipóteses, seria mais difícil imaginar um aumento significativo dos montantes das indenizações compensatórias, mas ainda assim outros instrumentos mostram-se disponíveis sem a necessidade de reformas tão drásticas quanto aquelas que se fariam necessárias para o agasalhamento dos punitive damages no ordenamento brasileiro. Pode-se, por exemplo, estabelecer sanções administrativas, tais como multas e suspensões aplicadas pelos órgãos reguladores da atividade do ofensor (Banco Central, CVM etc.). O sistema de sanções administrativas possui, a um só tempo, a dupla vantagem de superar o problema do enriquecimento sem causa da vítima - já que o eventual ganho econômico é destinado ao poder público -, e desestimular, de forma muitas vezes mais eficiente, a conduta antijurídica, pelo próprio relacionamento jurídico-político existente entre os agentes lesivos e o órgão regulador de sua atividade. Tudo 
Nesse sentido, o sistema de defesa da concorrência brasileiro se aproxima muito mais do europeu do que do norte-americano. No direito comunitário europeu, a exemplo do brasileiro, o controle de condutas anticompetitivas que afetem o mercado comum é exercido primordialmente por uma autoridade administrativa (a Comissão Europeia) com poderes para aplicar penalidades aos envolvidos.

Nesse contexto, as legislações dos Estados Membros da União Europeia não preveem a possibilidade de majoração da condenação ao ressarcimento de danos patrimoniais em matéria concorrencial como forma de punição ${ }^{389}$. No direito comunitário, a Diretiva sobre o assunto aprovada na União Europeia não contempla qualquer espécie de condenação com caráter punitivo no âmbito das ações indenizatórias. Como adiantado, o artigo $3^{\circ}$ da Diretiva dispõe que a indenização deve fazer com que o lesado retorne à posição que estaria caso a infração não tivesse ocorrido, prevendo expressamente que, nos termos da Diretiva, a indenização não deve resultar em compensação excessiva ("overcompensation”), seja por meio de "punitive damages" ou de fatores multiplicadores da indenização.

De outro lado, o sistema norte-americano, no qual se inspira a ideia de um fator multiplicador das indenizações por cartel, apresenta diferenças significativas em relação ao sistema brasileiro. Em primeiro lugar, como comumente apontado, as condenações com caráter punitivo são incorporadas há séculos no sistema de responsabilidade civil norte-americano ${ }^{390}$, diferentemente do que ocorre no direito brasileiro.

Além disso, conforme estudado no capítulo 4, estima-se que nos Estados Unidos cerca de $90 \%$ (noventa por cento) da aplicação da legislação antitruste ocorra por meio de ações individuais movidas por particulares, diferentemente do que ocorre no

de forma menos tormentosa do que ocorreria com o acolhimento de indenizações punitivas" (Novos Paradigmas da Responsabilidade Civil, cit., pp. 213-215).

389 "The nature of damages in all countries is compensatory and no exemplary or punitive damages are available" (BOJANA VRCEK, "Overview of Europe", cit., p. 288).

${ }^{390}$ American Bar Association, Punitive Damages and Business Torts: A Practitioners' Handbook, cit., pp. 612. 
Brasil e na União Europeia, em que, como visto, a aplicação da legislação concorrencial é feita, sobretudo, pelas autoridades administrativas.

Como esclarece Wouter P. WiLS, o sistema de "treble damages" é decorrência, em grande parte, do histórico e das especificidades da aplicação da legislação concorrencial nos Estados Unidos. No início de vigência do Sherman Act, não havia qualquer verba orçamentária destinada à investigação de práticas anticompetitivas e, mesmo após o Departamento de Justiça passar a investigar criminalmente tais condutas, até meados dos anos 1970 as penalidades pecuniárias não podiam ultrapassar o valor de US\$ 50.000,00 (cinquenta mil dólares). Tais fatores, segundo o autor, deixaram um vácuo na aplicação da legislação concorrencial, o qual era preenchido pelos "treble damages" aplicados no âmbito das ações indenizatórias ${ }^{391}$.

Note-se ainda que, mesmo no direito norte-americano, há autores que criticam o sistema de "treble damages", sustentando que a aplicação de condenações equivalentes ao triplo dos prejuízos tem por consequência a proliferação de ações indenizatórias, o que pode resultar em um nível excessivo de prevenção (overdeterrence), conforme analisado no capítulo 4.

Mesmo entre os defensores do sistema, há autores que sustentam que os chamados "treble damages" na realidade constituem "single damages", pois naquele sistema nem todos os prejuízos sofridos pela vítima são incluídos no montante da indenização $^{392}$. Como exemplo, aponta-se que as condenações ao pagamento de indenização por práticas anticompetitivas nos Estados Unidos apenas raramente incluem os chamados "prejudgment interest", ou seja, os juros de mora referentes ao período anterior ao julgamento ${ }^{393}$, os quais ordinariamente estão incluídos nas indenizações no direito

\footnotetext{
391 “The Relationship Between Public Antitrust Enforcement and Private Actions for Damages”, cit., pp. 1718.

${ }^{392}$ ROBERT. H. LANDE, "Benefits of Private Enforcement: Empirical Background”, cit., pp. 7-9.

393 "Because the bar is set so high for a plaintiff to show that it is entitled for an award of pre-judgment interest, it appears that no court to date has awarded prejudgment interest to a successful antitrust plaintiff" (W. Joseph Bruckner e Matthew R. SAlzwedel, "Plaintiffs' Remedies", in in Albert A. Foer e JonAthan W. CUNEO (org.), The International Handbook of Private Enforcement of Competition Law, cit., p. 207).
} 
brasileiro e podem fazer diferença significativa a depender do tempo de duração do processo $^{394}$.

Não se pode ainda perder de vista que, conforme estudado no capítulo 5, no direito brasileiro a jurisprudência atualmente já admite que o montante das condenações por danos morais (individuais e coletivos) seja acrescido de um valor adicional a título de punição do infrator como medida de desestímulo. Nesse contexto, a possibilidade de elevação das indenizações por danos patrimoniais decorrentes do cartel, também como medida de desestímulo, exacerbaria ainda mais o potencial de "bis in idem”, o qual já foi apontado no capítulo 5 com relação aos danos morais e, em especial, com relação aos danos morais coletivos.

Em síntese, entendemos que a obrigação de indenizar os prejuízos causados - os quais em muitos casos serão significativos - já pode contribuir bastante para desestimular a prática de cartel, não havendo necessidade de introduzir no Brasil regra inspirada nos "treble damages" do direito norte-americano. Tal regra, em nosso entender, considerando a existência de punições nas esferas administrativa e penal, bem como os critérios atualmente empregados na jurisprudência brasileira para fixação de indenização por danos morais, poderia resultar numa injustificada e indesejável multiplicidade de punições pela mesma prática em diferentes esferas.

\subsection{Análise da proposta de atribuição de caráter vinculante (ou de presunção relativa) às decisões do $\mathrm{CADE}$ com relação à existência do cartel}

Outra proposta de alteração do sistema brasileiro é a adoção de regra pela qual as decisões condenatórias do CADE teriam caráter vinculante com relação à existência da infração à ordem econômica, a exemplo do que já ocorre com relação à sentença condenatória na esfera criminal. Entende-se que tal regra tenderia a facilitar o ajuizamento de ações de indenização por parte dos prejudicados, que, desse modo, não

\footnotetext{
${ }^{394}$ Nos termos do artigo 404 do Código Civil "as perdas e danos, nas obrigações de pagamento em dinheiro, serão pagas com atualização monetária segundo índices oficiais regularmente estabelecidos, abrangendo juros, custas e honorários de advogado, sem prejuízo da pena convencional".
} 
precisariam provar a existência do ato ilícito, mas apenas a ocorrência de dano e nexo causal $^{395}$.

Sobre o assunto, conforme examinado no capítulo 4, a Diretiva aprovada na União Europeia sobre o tema estabelece que as legislações dos Estados Membros deverão prever que as decisões condenatórias proferidas por autoridades nacionais de defesa da concorrência serão vinculantes perante os tribunais dos Estados Membros com relação à existência da infração concorrencial.

Embora tal regra de fato pudesse facilitar a tarefa dos autores de ações indenizatórias por práticas já condenadas pelo CADE, sua introdução no direito brasileiro encontraria óbice no artigo $5^{\circ}$, inciso XXXV, da Constituição Federal, o qual dispõe que "a lei não excluirá da apreciação do Poder Judiciário lesão ou ameaça de direito"396. Considerando que tal garantia pode ser considerada cláusula pétrea e, como tal, insuscetível de emenda constitucional, nos termos do artigo $60, \S 4^{\circ}$, inciso IV, da Constituição Federal ${ }^{397}$, conclui-se que a introdução da regra seria praticamente inviável no sistema constitucional atual.

Nesse contexto, entende-se que seria mais adequado - e viável - adotar regra intermediária pela qual as decisões do CADE teriam caráter de presunção relativa com relação à existência do cartel, a qual poderia ser afastada por outras provas a serem produzidas pelo réu.

Entendemos que tal regra atenderia de maneira equilibrada aos diversos valores envolvidos, eis que: (i) teria o efeito de facilitar a prova do cartel e, desse modo,

\footnotetext{
395 Como adiantado, LuIZ CARLOS BUChaIN faz proposta nesse sentido: "Neste caso, a conduta lesiva, já examinada e decidida pelo CADE, teria o efeito análogo ao da sentença penal condenatória e o valor de coisa julgada como conduta culposa no direito civil. A decisão administrativa acerca da existência e caracterização da infração concorrencial seria aproveitada no campo da responsabilidade civil concorrencial, restando ao interessado a prova do dano e do nexo de causalidade" (O Poder Econômico e a Responsabilidade Civil Concorrencial, cit., p. 126).

${ }^{396}$ LUIZ CARLOS BUCHAIN reconhece a necessidade de reforma constitucional para a adoção da regra proposta no direito brasileiro (O Poder Econômico e a Responsabilidade Civil Concorrencial, cit., pp. 126127).

397 “Art. 60. (...) $\S 4^{\circ}$ - Não será objeto de deliberação a proposta de emenda tendente a abolir: (...) IV - os direitos e garantias individuais".
} 
estimular o ajuizamento de ações indenizatórias por práticas já condenadas pelo CADE; e (ii) por outro lado, preservaria a possibilidade de revisão judicial das decisões do $\mathrm{CADE}^{398}$.

\subsection{Início do prazo prescricional apenas após o conhecimento do dano e suspensão do prazo na pendência de processo administrativo no CADE}

Conforme analisado no capítulo 5, o prazo de prescrição aplicável às ações indenizatórias por danos decorrentes da prática de cartel é o previsto no artigo $206, \S 3^{\circ}$ do Código Civil, que dispõe que prescreve em 3 (três) anos a pretensão de reparação civil.

Como visto, há divergência na jurisprudência com relação ao termo inicial do prazo prescricional: alguns julgados do Superior Tribunal de Justiça sustentam que tal prazo somente começa a contar a partir do efetivo conhecimento do dano, ao passo que outros julgados sustentam, como regra geral, que o prazo prescricional tem início a partir da violação do direito, independentemente da ciência pelo prejudicado ${ }^{399}$.

Essa última orientação, como visto, caso prevaleça em casos envolvendo responsabilidade civil por danos decorrentes da prática de cartel, poderá prejudicar ou até mesmo inviabilizar a reparação de tais danos no Brasil, uma vez que o cartel é uma infração caracterizada pelo sigilo. Embora no direito vigente seja defensável sustentar que o prazo somente se inicia a partir da ciência do dano (ver capítulo 5), a ausência de norma

\footnotetext{
398 JoSÉ IGNÁCIO BOTELHO DE MESQUITA sustenta que "é perfeitamente possível concluir que as decisões do CADE estão sujeitas ao controle do Judiciário quanto à observância dos princípios da legalidade, da impessoalidade, da eficiência e da moralidade administrativa, incluindo-se no princípio da legalidade a observância das normas que dizem respeito à 'competência e a manifestação de vontade do agente, quanto ao motivo, ao objeto, à finalidade e à forma', tal como ocorre em relação a qualquer outro ato administrativo" ("A Judicialização do Direito da Concorrência", in Revista de Direito Mercantil, Industrial, Econômico e Financeiro, vol. 155/156, ago./dez., 2010, p. 18). Com relação ao tema, em estudo coordenado por JULIANO Souza Albuquerque maranhão, Paulo Furquim de Azevedo e Tércio Sampaio Ferraz Júnior, conclui-se que "a revisão judicial das decisões de agências reguladoras constitui uma tarefa de fundamental importância atribuída ao Poder Judiciário. Agências desprovidas de controle externo correm o risco de se tornarem politizadas, capturadas pelos interesses dos grandes agentes regulados, dado que estes podem ser fontes empregadoras ou potenciais clientes quando o servidor passa para o setor privado, e atuarem de forma arbitrária, sem a devida motivação técnica que motivou a própria criação desses órgãos no Estado regulador" (Direito Regulatório e Concorrencial no Poder Judiciário, São Paulo, Editora Singular, 2014, p. 247). Sobre a possibilidade de revisão judicial de decisões do CADE, ver também: JosÉ MARCELO MARTINS PROENÇA, Concentração Empresarial..., cit., pp. 161-182.

399 No caso de um consumidor, como visto, o art. 27 do Código de Defesa do Consumidor prevê prazo prescricional de 5 (cinco) anos e estabelece expressamente a fluência do prazo a partir do conhecimento do dano e de sua autoria.
} 
expressa nesse sentido e a falta de posição consolidada da jurisprudência podem constituir em fator de desestímulo à propositura de ações indenizatórias pelos prejudicados.

No direito comunitário europeu, como visto, a Diretiva aprovada na União Europeia procurou solucionar essa questão prevendo que as legislações dos Estados Membros deverão prever que: (i) o prazo prescricional para a pretensão de reparação de danos oriundos de práticas anticompetitivas não deverá começar a correr antes que o prejudicado possa ter ciência da infração; e (ii) o prazo deverá ser suspenso ou interrompido na pendência de investigação da prática por autoridade de defesa da concorrência.

Por todas as razões, entendemos que seria conveniente a adoção de norma no direito brasileiro que, a exemplo da Diretiva aprovada na União Europeia, preveja que, em caso de infrações à ordem econômica, o prazo de prescrição para reparação dos danos somente se inicia após o prejudicado ter condições de ter conhecimento da prática ou dos danos sofridos, bem como que tal prazo se interrompe na pendência de processo administrativo em trâmite no CADE.

\subsection{Disciplina da interação entre o programa de leniência e as ações de responsabilidade civil}

Como analisado nos capítulos precedentes, a interação entre os programas de leniência e as ações de responsabilidade civil por danos oriundos de cartel desperta importante discussão na doutrina concorrencial. Com efeito, as confissões dos signatários de acordos de leniência tendem a deixá-los mais expostos às ações de indenização, de modo que a ausência de normas disciplinando a questão pode consistir em desestímulo ao programa de leniência, o qual constitui importante ferramenta de detecção de cartéis.

Por tais razões, conforme estudado no capítulo 4, no direito norte-americano e no direito comunitário europeu há regras expressas que procuram disciplinar a questão, com o objetivo de evitar que as ações indenizatórias prejudiquem o programa de leniência.

Nesse sentido, a Diretiva aprovada na União Europeia estabelece proibição expressa de utilização das confissões dos signatários de acordos de leniência no âmbito de 
ações de indenização, facultando, em compensação, o acesso aos outros documentos constantes dos autos dos processos administrativos - inclusive às evidências fornecidas pelo beneficiário do acordo de leniência - desde que preenchidos certos requisitos.

Além disso, no caso dos beneficiários do acordo de leniência, a Diretiva estabelece uma exceção à regra geral de que todos os membros do cartel respondem solidariamente pela totalidade dos prejuízos gerados pelo cartel: de acordo com a Diretiva, os beneficiários da leniência respondem apenas pelos prejuízos causados aos adquirentes diretos e indiretos de seus próprios produtos.

De modo semelhante, no direito norte-americano há importante exceção às regras de "treble damages" (condenação ao pagamento de valor equivalente ao triplo dos prejuízos causados) e de responsabilidade solidária entre os membros do cartel. Conforme analisado no capítulo 4, o beneficiário da leniência responde apenas pelo prejuízo que causou ao autor ("single damages") em razão dos produtos ou serviços que ele mesmo tenha vendido com sobrepreço.

No Brasil, como estudado no capítulo 5, não há regras disciplinando a interação entre as ações indenizatórias e o programa de leniência. Com o desenvolvimento da responsabilidade civil em matéria concorrencial, tal lacuna poderá resultar em desestímulo aos acordos de leniência, o que, no limite, também pode prejudicar a reparação dos prejuízos, uma vez que menos cartéis serão identificados e, consequentemente, os danos não serão objeto de reparação.

Nesse sentido, entendemos que seria conveniente a adoção das seguintes regras no ordenamento jurídico brasileiro:

i) proibição de acesso ao teor do acordo do leniência e do Histórico da Conduta, facultando-se, por outro lado, a utilização dos demais documentos constantes do processo administrativo, inclusive as evidências disponibilizadas pelo beneficiário da leniência (e-mails, planilhas, etc.), desde que demonstrada a necessidade e tomadas medidas para resguardar eventuais documentos confidenciais: tal regra, em nosso entender, atenderia de modo equilibrado aos diferentes valores em jogo reparação dos prejuízos e necessidade de preservar o programa de leniência - pois 
evitaria que o beneficiário da leniência ficasse em situação mais desvantajosa do que os demais membros do cartel (resguardando o sigilo da confissão e do Histórico da Conduta) e, por outro lado, permitiria o acesso dos representados a documentos relevantes que podem servir de prova no âmbito das ações de indenizações;

ii) previsão de que o beneficiário da leniência deva responder apenas pelos prejuízos causados em decorrência das vendas de seus próprios produtos ou serviços, sem precisar arcar solidariamente com a totalidade dos prejuízos causados pelo cartel; de igual modo; tal regra evitaria que o signatário da leniência, que em muitos casos é incluído como o único réu nas ações indenizatórias - como ocorreu, por exemplo, na ação do Estado de São Paulo contra a Siemens - seja obrigado a arcar com a totalidade dos prejuízos causados pelo cartel, o que poderia consistir em desestímulo ao programa de leniência; por outro lado, preserva-se o interesse dos prejudicados em ver ressarcidos os prejuízos, pois o beneficiário da leniência continua sendo obrigado a arcar com os prejuízos causados em razão da venda de seus próprios produtos ou serviços com sobrepreço; e

iii) previsão de que os beneficiários da leniência fiquem isentos de responsabilidade por danos morais coletivos: dada a natureza predominantemente punitiva dos danos morais coletivos, conforme estudado no capítulo 5, evitar-se-ia dessa forma que a isenção de penalidades na esfera administrativa fosse anulada em razão da condenação ao pagamento de danos morais coletivos, o que também poderia consistir em desincentivo à assinatura de acordos de leniência.

Em essência, entendemos que as regras acima atenderiam de maneira adequada e equilibrada aos dois valores em discussão, atenuando potenciais desincentivos ao programa de leniência e, ao mesmo tempo, preservando o direito dos prejudicados de serem ressarcidos pelos danos causados. 


\section{CONCLUSÃO}

Com base na análise empreendida nos capítulos acima, serão indicadas a seguir as principais conclusões a que se chegou ao longo deste trabalho, na ordem em que foram expostas:

i) os principais efeitos da prática de cartel, considerada a mais grave violação à ordem econômica, são a transferência de renda dos consumidores para os agentes cartelizados, a redução da oferta no mercado (gerando o chamado "peso morto") e a redução dos incentivos para que as empresas invistam em melhoria dos produtos e redução de custos, efeitos que justificam a preocupação das legislações em coibir a prática;

ii) de modo geral, a doutrina identifica dois objetivos principais para a responsabilidade civil em matéria antitruste: reparação dos prejuízos sofridos pelos prejudicados e, além disso, servir de desestímulo à prática de novas infrações concorrenciais, contribuindo para a política de prevenção de infrações à ordem econômica;

iii) a ênfase atribuída a cada um dos objetivos acima destacados (reparação e prevenção) varia conforme o sistema jurídico analisado: a análise do direito estrangeiro demonstrou que o modelo adotado no direito federal norte-americano confere maior ênfase ao objetivo da prevenção do que o modelo do direito comunitário europeu, que dá maior ênfase ao objetivo de reparação integral dos prejuízos; as diferenças podem ser ilustradas pelo montante da indenização aplicável em cada um dos sistemas (nos Estados Unidos o prejudicado tem direito a receber valor equivalente ao triplo dos prejuízos, enquanto no direito europeu a indenização se mede pela extensão do dano), pela admissibilidade da chamada "pass-on defense" (inadmitida nos direito federal norte-americano e admitida no direito europeu) e pela legitimidade dos compradores indiretos (inadmitida no direito federal norte-americano e admitida no direito europeu); 
iv) no direito brasileiro, os envolvidos na prática de cartel estão sujeitos a responsabilização em três esferas distintas e complementares: administrativa, penal e civil;

v) com relação à responsabilidade civil em matéria antitruste no direito brasileiro, a existência de norma expressa na Lei 12.529/2011 assegurando aos prejudicados o direito de obterem indenização por perdas e danos não deve ser interpretada como uma simples repetição da regra geral do artigo 927 do Código Civil, mas sim como um dispositivo que viabiliza a aplicação dos princípios da lei concorrencial no âmbito da responsabilidade civil por cartel e outras infrações;

vi) a Lei 12.529/2011 confere legitimidade ativa para a propositura de ações de indenização em matéria antitruste aos "prejudicados", sem fazer distinção entre compradores diretos ou indiretos, de modo que, diferentemente do que ocorre no direito federal norte-americano, não se justifica no direito brasileiro eventual interpretação no sentido de negar legitimidade aos compradores indiretos;

vii) o ressarcimento pelos danos decorrentes de infração à ordem econômica pode ser pleiteado pelos prejudicados individualmente (incluindo empresas, consumidores ou entes federados que tenham sido lesados) ou, em sede de tutela coletiva, por intermédio da legitimação extraordinária prevista no art. 82 do Código de Defesa do Consumidor;

viii) o CADE não tem legitimidade para a propositura de ações de indenização em matéria concorrencial, uma vez que tal prerrogativa prejudicaria a imparcialidade da autarquia no exercício de suas funções e, de resto, o artigo 118 da Lei 12.529/2011 já estabelece o papel do CADE em ações que discutam a aplicação da lei concorrencial, dispondo que o CADE será intimado para, querendo, intervir no feito na qualidade de assistente;

ix) o primeiro dos pressupostos da responsabilidade civil é a prática de um ato ilícito que, no caso do cartel, consiste no acordo entre concorrentes com o objetivo de eliminar a competição entre si e fixar conjuntamente preços e quantidades, dividir mercados ou fraudar o caráter competitivo de licitações; 
x) no direito brasileiro, diferentemente do que ocorre em outros países, eventual decisão condenatória proferida na esfera administrativa não é vinculante perante o juízo civil, que poderá ter entendimento diverso do CADE com relação à caracterização da conduta ilícita; em caso de decisão condenatória por cartel na esfera penal, por outro lado, tal decisão será vinculante na esfera civil com relação à existência do fato e sua autoria (Código Civil, art. 935);

xi) conclui-se que a responsabilidade civil em matéria de cartel prescinde da demonstração do elemento culpa, com fundamento na conjugação do parágrafo único do artigo 927 do Código Civil (que prevê a responsabilidade sem culpa nos casos previstos em lei), artigo 36 da Lei 12.529/2011 (que dispõe que a infração à ordem econômica ocorre "independentemente de culpa") e artigo 47 da Lei 12.529/2011 (que assegura aos prejudicados por infrações à ordem econômica o direito de pleitearem a reparação dos prejuízos); no caso dos administradores, no entanto, a Lei 12.529/2011 expressamente dispõe que a responsabilização pressupõe a demonstração de "culpa ou dolo" (art. 37, inc. III), exigência que pode ser aplicada por analogia no caso das "demais pessoas físicas" envolvidas na prática de cartel;

xii) a caracterização do nexo causal pressupõe a demonstração de que o dano foi consequência do acordo ilícito entre os concorrentes, o que independe das relações contratuais porventura existentes entre autor e réu da ação de indenização, de modo que: (a) o prejudicado pode ajuizar ação de indenização contra todos os membros do cartel, mesmo que eventualmente não tenha adquirido produtos ou serviços de todos eles (a conduta dos demais membros também guarda relação de causalidade com o prejuízo sofrido, pois na ausência do acordo ilícito nenhum dos membros do cartel teria condições de impor preços mais elevados aos adquirentes); e (b) o prejudicado pode cobrar indenização mesmo que não tenha adquirido produtos ou serviços diretamente de nenhum dos membros do cartel, tendo sofrido os efeitos do repasse ("pass-on") do sobrepreço por outro adquirente localizado em etapa anterior da cadeia produtiva; 
xiii) a necessidade de demonstrar os danos sofridos pelos prejudicados é o principal traço distintivo entre, de um lado, a responsabilidade na esfera administrativa (que, como visto, exigem apenas a demonstração de potencialidade de produção de efeitos anticompetitivos) e, de outro lado, a responsabilidade civil pela prática de cartel (que pressupõe a demonstração de que o cartel causou dano aos prejudicados);

xiv) no caso do cartel, o dano patrimonial (ou material) decorre do chamado sobrepreço, o qual não pode ser medido com precisão absoluta, pois sua quantificação depende da comparação entre o preço pago pelo prejudicado e o preço que vigoraria em um cenário hipotético em que o cartel não tivesse existido; a interpretação mais coerente com os objetivos da lei concorrencial é aquela que, a exemplo das soluções adotadas em outros países, possibilita a quantificação com base em estimativas baseadas em estudos econômicos (por exemplo, comparação entre os preços vigentes no mercado antes e depois do cartel, comparação com os preços vigentes em outros mercados, dentre muitos outros métodos);

xv) a chamada "pass-on defense" (i.e., alegação de que o adquirente direto não tem direito à indenização por ter repassado o sobrepreço aos seus próprios clientes) é admitida no direito brasileiro; o ônus de provar o repasse é do réu (CPC, art. 333, III), que, no entanto, caso consiga demonstrar que os documentos necessários para a prova do repasse estão na posse do autor, poderá requerer que o réu os exiba nos autos (CPC, art. 355);

xvi) é possível cumular indenização por danos emergentes e lucros cessantes oriundos do sobrepreço, o que ocorrerá, por exemplo, caso o adquirente absorva parcela do sobrepreço (fazendo jus a indenização por danos emergentes) e, ao repassar a outra parcela do sobrepreço ao preço de seus próprios produtos, sofra redução nas vendas, causando-lhe lucros cessantes;

xvii) a indenização por danos patrimoniais no direito brasileiro se mede pela extensão do dano (Código Civil, art. 944), não havendo possibilidade de aplicação de um fator multiplicador da indenização como medida de desestímulo à prática de cartéis, a 
exemplo da condenação pelo triplo dos prejuízos ("treble damages”) do direito norte-americano;

xviii) por outro lado, a doutrina e a jurisprudência admitem a reparação de danos morais (individuais e coletivos) ocasionados pelos cartéis, cuja quantificação, nos termos da jurisprudência, pode levar em conta a necessidade de punir o infrator como forma de desestímulo à prática de novas infrações;

xix) concluiu-se que, em matéria concorrencial, a aplicação da chamada função punitiva dos danos morais, em especial com relação aos danos morais coletivos, acarreta risco de sobreposição com a atividade punitiva exercida pelo CADE; desse modo, caso o cartel já tenha sido punido na esfera administrativa (ou penal) tal fato deverá ser levado em conta na fixação dos danos morais, de modo a afastar eventual "bis in idem";

xx) no direito brasileiro, embora haja dispositivos prevendo o tratamento sigiloso da proposta de acordo de leniência e proibindo os demais investigados de compartilharem documentos e informações disponibilizadas pelo beneficiário da leniência, não há norma que trate da possibilidade de os prejudicados solicitarem que o Poder Judiciário conceda o acesso a tais documentos para fins de instrução das ações indenizatórias, tampouco norma disciplinado eventuais limites a esse acesso; como visto, há precedentes recentes admitindo o acesso a tais documentos em prol do interesse do Estado em ser ressarcido pelos prejuízos causados pelos cartéis;

xxi) o prazo de prescrição da pretensão reparatória dos danos causados por cartéis é de 3 (três) anos (Código Civil, art. 206, § $3^{\circ}, \mathrm{V}$ ), sendo possível sustentar que tal prazo somente se inicia no momento em que o prejudicado possa ter ciência do dano, embora haja divergência jurisprudencial sobre o tema; caso a ação seja movida para o ressarcimento de prejuízos sofridos por consumidores, o prazo prescricional é de 5 (cinco) anos e somente se inicia a partir do conhecimento do dano e de sua autoria (Código de Defesa do Consumidor, art. 27); como a prática de cartel também constitui crime, pode-se ainda sustentar a aplicação do artigo 200 do Código Civil, 
segundo o qual não correrá a prescrição antes da sentença definitiva no juízo criminal.

Depois de sintetizadas as principais conclusões, cabe aqui avaliar o modelo brasileiro de responsabilidade civil por cartel à luz da discussão travada no capítulo 3, para tentar identificar qual dos dois objetivos principais da responsabilidade civil concorrencial é priorizado no sistema brasileiro: a reparação dos prejuízos ou a prevenção de infrações concorrenciais.

Após a análise empreendida neste estudo, conclui-se que o sistema brasileiro guarda mais semelhanças com o sistema europeu, que enfatiza a reparação integral dos prejuízos, do que com o sistema do direito federal norte-americano, que dá mais ênfase ao objetivo de prevenção de infrações concorrenciais.

As razões para essa conclusão decorrem das seguintes semelhanças entre o sistema brasileiro e o europeu, todas elas examinadas ao longo deste trabalho: (i) o montante da indenização por danos patrimoniais, que, no direito brasileiro e no direito comunitário europeu, mede-se pela extensão do dano; (ii) a admissibilidade da chamada "pass-on defense", admitida tanto no direito europeu como no brasileiro; e (iii) a legitimidade conferida aos compradores indiretos nos sistemas europeu e brasileiro.

Por outro lado, uma característica do modelo brasileiro que revela uma potencial abertura para que se enfatize o objetivo de prevenir novas infrações é a quantificação dos danos morais (que, como visto, admite critérios associados à punição e desestímulo de condutas ilícitas) e, sobretudo, a admissibilidade de danos morais coletivos em matéria de cartel, os quais possuem nítido caráter punitivo e, conforme destacado acima, geram o risco de "bis in idem" com as punições aplicadas nas esferas administrativa e penal.

Em realidade, o fato é que, na prática, nenhum dos dois objetivos tem sido adequadamente atendido no sistema brasileiro: as ações de indenização em matéria concorrencial ainda são escassas no Brasil - especialmente em comparação com os Estados Unidos e até mesmo com a Europa - de modo que os prejudicados não têm conseguido obter a reparação dos prejuízos, nem tampouco as ações indenizatórias tem servido para 
complementar os esforços de prevenção de cartéis adotados pelo CADE e pelas autoridades de persecução penal. Nas palavras de voto proferido em decisão do CADE transcrita na introdução deste trabalho, "perde-se, assim, um importante fator a desestimular a prática de conluio. E os prejudicados também deixam de ser ressarcidos pelos danos causados" ${ }^{\prime 400}$.

A partir desse diagnóstico, o trabalho procurou examinar algumas das principais propostas de aperfeiçoamento do sistema brasileiro de responsabilidade civil por danos decorrentes da prática de cartel. Desde logo, foi afastada a conveniência de adoção de um fator multiplicador das indenizações inspirado nos "treble damages" do modelo norte-americano.

Com efeito, o reconhecimento de que as ações indenizatórias também servem ao propósito de prevenir a prática de ilícitos concorrenciais não significa necessariamente que a indenização deva ser acrescida de um montante "punitivo" ou "dissuasório": o simples fato de ser obrigado a reparar os prejuízos já constitui importante elemento de desestímulo ao potencial infrator, que será tão mais eficaz quanto mais ações indenizatórias forem ajuizadas com sucesso.

Nesse contexto, entendemos que outras propostas de reforma do ordenamento jurídico são mais aptas a proporcionar o aperfeiçoamento do modelo brasileiro, quais sejam: (i) a atribuição de caráter de presunção relativa à decisão condenatória proferida pelo CADE; (ii) a introdução de regra prevendo expressamente que o prazo prescricional da pretensão de reparação dos danos somente se inicia após o prejudicado ter condições de ter conhecimento da prática ou dos danos sofridos (de modo a eliminar as incertezas decorrentes da divergência jurisprudencial sobre o tema), bem como que tal prazo se interrompe na pendência de processo administrativo em trâmite no CADE; e (iii) a edição de regra disciplinando a interação entre os programas de leniência e as ações de indenização em matéria concorrencial.

400 Voto do Conselheiro Relator Fernando de Magalhães Furlan no processo administrativo $\mathrm{n}^{\circ}$ 08012.009888/2003-70, julgado em 01.09.2010. 
De qualquer modo, mesmo na ausência das medidas sugeridas acima, o quadro normativo brasileiro tal como delineado atualmente já permitiria a reparação dos danos causados por cartéis, ao menos em proporção muito maior do que a verificada na prática atual.

O fato é que a mais importante contribuição ao desenvolvimento da responsabilidade civil por danos decorrentes da prática de cartel no Brasil deverá ser dada pela jurisprudência. Como estudado neste trabalho, as questões relativas à demonstração e quantificação do sobrepreço - apontadas internacionalmente como a maior dificuldade enfrentada pelos prejudicados para obterem o ressarcimento dos prejuízos - ainda não foram adequadamente solucionadas pela jurisprudência brasileira.

Enquanto nos Estados Unidos e na União Europeia há posicionamento claro no sentido de que o cálculo dos prejuízos pode ser feito por meio de estimativas baseadas em estudos econômicos, empregando-se critérios razoáveis e acessíveis às partes, os pouquíssimos precedentes em que houve condenação ao ressarcimento do sobrepreço no Brasil não estabeleceram quaisquer parâmetros que possam servir de orientação aos prejudicados que pretendam ajuizar ação indenizatória.

Essa ausência de precedentes, aliada à natural dificuldade de calcular os prejuízos decorrentes do sobrepreço, constitui fator inibitório do ajuizamento de ações de indenização em matéria de cartel. Além de arcarem com os custos envolvidos no litígio que podem ser elevados caso haja necessidade de prova pericial complexa -, os litigantes atualmente precisam conviver com a incerteza e com o risco de, ao final do processo, o juiz entender que o critério empregado para o cálculo do sobrepreço não é admissível.

Desse modo, ao julgarem as demandas ajuizadas sobre o tema - aquelas já em curso e as que deverão ser ajuizadas em número crescente em decorrência da consolidação da cultura de defesa da concorrência no Brasil -, os tribunais deverão compreender a natureza dos danos causados pelos cartéis e, sobretudo, os critérios peculiares de quantificação do sobrepreço, fixando critérios que, a exemplo das soluções adotadas em outros países, viabilizem a reparação dos prejuízos. 
Caso assim procedam, os tribunais estarão dando contribuição decisiva para o desenvolvimento da disciplina, possibilitando que a responsabilidade civil por danos decorrentes da prática de cartel cumpra com os objetivos discutidos neste trabalho, viabilizando a reparação dos prejuízos e, além disso, contribuindo com a prevenção da prática de cartel. 


\section{REFERÊNCIAS}

ADAMEK, Marcelo Vieira Von, Responsabilidade Civil dos Administradores de S/A e as Ações Correlatas, São Paulo, Saraiva, 2010.

AGUIAR DIAS, José de, Da Responsabilidade Civil, vol. II, $7^{\mathrm{a}}$ ed., Forense, Rio de Janeiro, 1983.

ALMEIDA, Fabrício Antonio Cardim de (coord.), Revisão Judicial das Decisões do Conselho Administrativo de Defesa Econômica (CADE) - Pesquisa Empírica e Aplicada sobre os Casos Julgados pelos Tribunais Regionais Federais (TRFs), Superior Tribunal de Justiça (STJ) e Supremo Tribunal Federal (STF), Belo Horizonte, Fórum, 2011.

ALPA, Guido; BESSONI, Mario, Atipicità dell'Illecito - Parte Prima: I Profili Dottrinali, $2^{\circ}$ ed., Milano, Dott. A. Giuffrè Editore, 1980.

ALVIM, Agostinho, Da Inexecução das Obrigações e Suas Consequências, $3^{\mathrm{a}}$ ed., São Paulo, Editora Jurídica e Universitária, 1965.

AMERICAN BAR ASSOCIATION, Antitrust Law Developments, vol. I, $6^{\text {th }}$ ed., ABA Section of Antitrust Law, 2007.

Punitive Damages and Business Torts: A Practitioners' Handbook, ABA Section of Antitrust Law, 1998.

, Proving Antitrust Damages: Legal and Economic Issues, $2^{\text {nd }}$ ed., ABA Section of Antitrust Law, 2010.

ANDERS, Eduardo Caminati; PAGOTTO, Leopoldo; BAGNOLI, Vicente (coord.), Comentários à Nova Lei de Defesa da Concorrência: Lei n. 12.529, de 30 de novembro de 2011, Rio de Janeiro, Forense, 2012. 
ANDRADE, Thompson, "Julgamento de Cartéis e o Uso de Provas Indiretas" in Revista de Direito da Concorrência, nº 1, jan./mar., 2004.

ANGELIN, Karine Ansiliero, Dano Injusto como Pressuposto do Dever de Indenizar, Dissertação de Mestrado, Faculdade de Direito da Universidade de São Paulo, 2012.

ANTITRUST MODERNIZATION COMMISSION, Antitrust Modernization Commission: Report and Recommendations, 2007, disponível em: <http://govinfo.library.unt.edu/amc/report_recommendation/amc_final_report.pdf $>$. Acesso em: 17.mar.2013.

AZEVEDO, Álvaro Villaça, "Conceito de Ato Ilícito e o Abuso de Direito", in RODRIGUES JÚNIOR, Octávio Luiz; MAMEDE, Gladston; ROCHA, Maria Vital (coord.), Responsabilidade Civil Contemporânea: em Homenagem a Sílvio de Salvo Venosa, São Paulo, Atlas, 2011.

, Teoria Geral das Obrigações e Responsabilidade Civil, 12a ed., São Paulo, Atlas, 2011.

AZEVEDO, Antonio Junqueira de, Estudos e Pareceres de Direito Privado, São Paulo, Saraiva, 2004.

, "Por uma Nova Categoria de Dano na Responsabilidade Civil: O Dano Social”, in Novos Estudos e Pareceres de Direito Privado, São Paulo, Saraiva, 2009.

BANDEIRA DE MELO, Celso Antônio, Curso de Direito Administrativo, $17^{\mathrm{a}}$ ed., São Paulo, Malheiros, 2004.

BECKER, Gary S., "Crime and Punishment: An Economic Approach", in Journal of Political Economy, vol. 76, 1968.

, "Nobel Lecture: The Economic Way of Looking at Behavior", in The Journal of Political Economy, vol. 101, n. 3, Jun., 1993. 
BESSA, Leonardo Roscoe, "Dano Moral Coletivo", in Revista da Direito e Liberdade, v. 7, 2007.

BEVILAQUA, Clovis, Direito das Obrigações, $5^{\mathrm{a}}$ ed., Rio de Janeiro, Freitas Bastos, 1940.

BITTAR, Carlos Alberto, Reparação Civil por Danos Morais, $3^{\mathrm{a}}$ ed., São Paulo, Revista dos Tribunais, 1999.

, Responsabilidade Civil: Teoria e Prática, $2^{\mathrm{a}}$ ed., Rio de Janeiro, Forense Universitária, 1990.

BITTAR FILHO, Carlos Alberto, "Do Dano Moral Coletivo no Atual Contexto Jurídico Brasileiro", in Revista de Direito do Consumidor, vol. 12, São Paulo, Revista dos Tribunais, 1995.

BOBBIO, Norberto, Da Estrutura à Função: Novos Estudos de Teoria do Direito, Barueri, Manole, 2007.

BORK, Robert H., The Antitrust Paradox - A Policy at War With Itself, New York, Free Press, 1993.

BREIT, William; ELZINGA, Kenneth G., "Private Antitrust Enforcement: The New Learning", in Journal of Law and Economics, vol. 28, n. 2, 1985.

BRIZ, Jaime Santos, La Responsabilidad Civil-Derecho Substantivo y Derecho Procesal, $6^{a}$ ed., vol. I e II, Madrid, Editorial Montecorvo, 1991.

BRUCKNER, W. Joseph; SALZWEDEL, Matthew R., "Plaintiffs' Remedies", in FOER, Albert A.; CUNEO, Jonathan W. (org.), The International Handbook of Private Enforcement of Competition Law, Cheltenham, Edward Elgar Publishing, 2010.

BRUNA, Sérgio Varella, O Poder Econômico e a Conceituação do Abuso de seu Exercício, São Paulo, Revista dos Tribunais, 2001. 
BRYANT, Peter G.; ECKARD, E. Woodrow, "Price Fixing: the Probability of Getting Caught”, in Review of Economics and Statistics, 73, 1991.

BUCHAIN, Luiz Carlos, O Poder Econômico e a Responsabilidade Civil Concorrencial, Porto Alegre, Nova Prova Editora, 2006.

CAHALI, Yussef Said, Dano Moral, 2ª ed., São Paulo, Revista dos Tribunais, 2000.

CALABRESI, Guido, "Some Thoughts on Risk Distribution and the Law of Torts", in Yale Law Journal, v. 70, 1970.

, The Costs of Accidents - A Legal and Economic Analysis, New Haven, Yale University Press, 1970.

CAVAlIERI FILHO, Sérgio, Programa de Responsabilidade Civil, 9a ed., São Paulo, Malheiros, 2010.

CAVANAGH, Edward D., "Detrebling Antitrust Damages: An Idea Whose Time Has Come?", in Tul. Law Review, 61, 777, 1987.

COASE, Ronald, "The Problem of Social Cost", in The Journal of Law \& Economics, vol. 3, 1960 .

COELHO, Fábio Ulhoa, Direito Antitruste Brasileiro - Comentários à Lei $n^{o}$ 8.884/94, São Paulo, Saraiva, 1995.

COMISSÃO EUROPEIA, Commission Staff Working Paper accompanying the White Paper on Damages Actions for Breach of the EC Antitrust Rules, 2008, disponível em: <http://eur-lex.europa.eu/LexUriServ/LexUriServ.do?uri=SEC:2008:0404:FIN:EN:PDF>. Acesso em: 5.abr.2013.

, Communication from the Commission to the European Parliament, the Council, the European Economic and Social Committee and the Committee of the Regions 
- Commission Work Programme, 2011, disponível em: <http://ec.europa.eu/atwork/pdf/cwp2012_annex_en.pdf>. Acesso em: 11.abr.2013.

, Draft Guidance Paper - Quantifying Harm in Actions for Damages Based on Breaches of Article 101 or 102 of the Treaty on the Functioning of the European Union, 2011 ,

<http://ec.europa.eu/competition/consultations/2011_actions_damages/draft_guidance_pap er_en.pdf>. Acesso em 27.abr.2013.

, Green Paper on Damages Actions for Breach of the EC Antitrust Rules, 2005, disponível em: <http://eurlex.europa.eu/LexUriServ/site/en/com/2005/com2005_0672en01.pdf>. Acesso em: 2.abr.2013.

Proposal for a Directive of the European Parliament and of the Council on Certain Rules Governing Actions for Damages under National Law for Infringements of the Competition Law Provisions of the Member States and of the European Union, disponível em: <http://eurlex.europa.eu/LexUriServ/LexUriServ.do?uri=COM:2013:0404:FIN:EN:PDF>. Acesso em: 21.set.2013.

, White Paper on Damages Actions for Breach of the EC Antitrust Rules, 2008 disponível em:

$<$ http://ec.europa.eu/competition/antitrust/actionsdamages/index.html>. Acesso em: 2.abr.2013.

CONNOR, John M., "The Impact of International Cartels", in FOER, Albert A.; CUNEO, Jonathan W. (org.), The International Handbook of Private Enforcement of Competition Law, Cheltenham, Edward Elgar Publishing, 2010.

CONNOR, John M.; LANDE, Robert H., "Cartel Overcharges and Optimal Cartel Fines" in American Bar Association, Issues in Competition Law and Policy, vol. 3, ABA Section of Competition Law, 2008. 
, "The Size of Cartel Overcharges: Implications for U.S. and EU Fining Policies", in The Antitrust Bulletin, vol. 51, n. 4, Winter, 2006.

COOTER, Robert D.; ULEN, Thomas, Law and Economics, $5^{\text {th }}$ ed., Boston, Addison Wesley, 2007.

CORDOVIL, Leonor; CARVALHO, Vinícius Marques de; BAGNOLI, Vicente; ANDERS, Eduardo Caminati, Nova Lei de Defesa da Concorrência Comentada - Lei 12.529, de 30 de novembro de 2011, São Paulo, Revista dos Tribunais, 2011.

CRUZ, Gisela Sampaio da, O Problema do Nexo Causal na Responsabilidade Civil, Rio de Janeiro, Renovar, 2005.

DAVID, René, Os Grandes Sistemas do Direito Contemporâneo, $3^{\mathrm{a}}$ ed., São Paulo, Martins Fontes, 1996.

DE STEFANO, Gianni, “Access of Damage Claimants to Evidence Arising Out of EU Cartel Investigations: A Fast-Evolving Scenario", in Global Competition Litigation Review, vol. 3, 2012.

DINIZ, Maria Helena, Curso de Direito Civil Brasileiro: Responsabilidade Civil, 24a ed., São Paulo, Saraiva, 2010.

DORETTO, Fernanda Orsi Baltrunas, Dano Moral Coletivo, Tese de Doutorado, Faculdade de Direito da Universidade de São Paulo, 2008.

EASTERBROOK, Frank H., "Detrebling Antitrust Damages", in Journal of Law and Economics, vol. 28, n. 2, 1985.

ELHAUGE, Einer; GERADIN, Damien, Global Competition Law and Economics, Portland, Hart Publishing, 2007. 
FERRARI, Eduardo Reale; GAMEIRO, João Augusto Prado da Silveira, O Cartel de Empresas e Seus Aspectos Criminais, sem data, disponível em: <http://www.realeadvogados.com.br/opinioes/edu_joao.pdf>. Acesso em: 8.nov.2014.

FERRAZ JÚNIOR, Tércio Sampaio, "Direito da Concorrência e Enforcement Privado na Legislação Brasileira", in Revista de Defesa da Concorrência, n 2, novembro de 2013.

, Introdução ao Estudo do Direito - Técnica, Decisão, Dominação, $3^{\mathrm{a}}$ ed., São Paulo, Atlas, 2001.

FISCHER, Hans Albrecht, A Reparação dos Danos, tradução de António de Arruda Ferrer Correa, São Paulo, Saraiva, 1938.

FONSECA, João Bosco Leopoldino da, "Cartéis - Tratamento Legal", in Revista do IBRAC, ano 18, vol. 19, 2011.

Lei de Proteção da Concorrência - Comentários à Legislação Antitruste, $3^{\mathrm{a}}$ ed., Rio de Janeiro, Forense, 2007.

FONSECA, Priscila M. P. Corrêa da, Dissolução Parcial, Retirada e Exclusão de Sócio, $5^{\mathrm{a}}$ ed., São Paulo, Atlas, 2012.

FORGIONI, Paula Andrea, "Análise Econômica do Direito (AED): Paranoia ou Mistificação?”, in Revista de Direito Mercantil, Industrial, Econômico e Financeiro, vol. 139, jul./set., 2005.

, Os Fundamentos do Antitruste, São Paulo, Revista dos Tribunais, 1998.

FRANCESCHINI, José Inácio Gonzaga, Introdução ao Direito da Concorrência, São Paulo, Malheiros, 1996.

FRANCISCO, André Marques, Responsabilidade Civil por Infração da Ordem Econômica, Dissertação de Mestrado, Faculdade de Direito da Universidade de São Paulo, 2014. 
FRAZÃO, Ana, "Principais Distinções e Aproximações de Responsabilidade Civil nos Modelos Francês, Alemão e Anglo-Saxão", in RODRIGUES JÚNIOR, Octávio Luiz; MAMEDE, Gladston; ROCHA, Maria Vital (coord.), Responsabilidade Civil Contemporânea: em Homenagem a Sílvio de Salvo Venosa, São Paulo, Atlas, 2011.

FREITAS, Paulo Felipe Carneiro de, Tutela Coletiva da Responsabilidade Civil por Infração da Ordem Econômica, Dissertação de Mestrado, Faculdade de Direito da Universidade de São Paulo, 2013.

GABAN, Eduardo Molan; DOMINGUES, Juliana Oliveira, Direito Antitruste, $3^{\text {a }}$ ed., São Paulo, Saraiva, 2012.

GÂNDARA, Lívia, "Responsabilidade Civil Concorrencial: Elementos de Responsabilidade Civil e Análise Crítica dos Problemas Enfrentados pelos Tribunais Brasileiros", in Revista do IBRAC, ano 19, vol. 21, 2012.

GELLHORN, Ernest; KOVACIC, William E., Antitrust Law and Economics in a Nutshell, $4^{\text {th }}$ ed., St. Paul, Minnesota, West Publishing, 1994.

GICO JÚNIOR, Ivo Teixeira, Cartel: Teoria Unificada da Colusão, São Paulo, Lex Editora, 2007.

GILBERTO, André Marques, O Processo Antitruste Sancionador: Aspectos Processuais na Repressão das Infrações à Concorrência no Brasil, São Paulo, Lex Editora, 2010.

GOMES, Orlando, Responsabilidade Civil, Rio de Janeiro, Forense, 2011.

GONÇALVES, Priscila Brólio, Direito Concorrencial: Aspectos Jurídicos e Econômicos Comentários à Lei 8.884/94 e Estudos Doutrinários, Rio de Janeiro, América Jurídica, 2002.

GONÇALVES, Carlos Roberto, Direito Civil Brasileiro, vol. 3, 9ª ed., São Paulo, Saraiva, 2012. 
, Responsabilidade Civil, 13 ${ }^{\mathrm{a}}$ ed., São Paulo, Saraiva, 2011.

GRAU, Eros Roberto, A Ordem Econômica na Constituição de 1988 (Interpretação e Crítica), $10^{\mathrm{a}}$ ed., São Paulo, Malheiros, 2005.

GRINBERG, Mauro; PAOLETTI, Camilla; CORDOVIL, Leonor, "Brazil", in FOER, Albert A.; CUNEO Jonathan W. (org.), The International Handbook of Private Enforcement of Competition Law, Cheltenham, Edward Elgar Publishing, 2010.

HOVEMKAMP, Herbert, Federal Antitrust Policy - The Law of Competition and its Practice, $2^{\text {nd }}$ ed., St. Paul - Minnesota, West Group, 1999.

IDOT, Laurence; ZIVY, Fabien, “L'accès au Dossier des Autorités de Concurrence dans le Cadre des Actions Privées: État des Lieux Deux Ans Après l'arrêt Pfleiderer", in Concurrences - Revue des Droits de la Concurrence, n. 3, 2013, disponível em: $<$ http://www.concurrences.com/spip.php?action=acceder_document\&arg=19467\&cle=01d 79932dee7715180e0719afaaa93547157a7b8\&file=pdf\%2F05a.concurrences_32013_doctrines_1._idot.pdf>. Acesso em: 31.out.2014.

IVALDI, Marc; JULIEN, Bruno; REY, Patrick; SEABRIGHT, Paul; TIROLE, Jean, The Economics of Tacit Collusion - Final Report for DG Competition, Comissão Europeia, IDEI Toulouse, 2003, disponível em: <http://ec.europa.eu/competition/mergers/studies_reports/the_economics_of_tacit_collusio n_en.pdf>. Acesso em: 29.ago.2014.

JOURDAIN, Patrice, Les Principes de La Responsabilité Civile, $5^{\mathrm{e}}$ ed., Paris, Dalloz, 2000.

KENSEN, Hans, Teoria Pura do Direito, Martins Fontes, São Paulo, 2000.

KREPS, David A., Microeconomics for Managers, New York, W.W. Norton \& Company, 2004. 
LANDE, Robert H., "Benefits of Private Enforcement: Empirical Background”, in FOER, Albert A.; CUNEO Jonathan W. (org.), The International Handbook of Private Enforcement of Competition Law, Cheltenham, Edward Elgar Publishing, 2010.

LANDES, William M., "Optimal Sanctions for Antitrust Violations", in University of Chicago Law Review, vol. 50, Spring, 1983.

LEVY, Daniel de Andrade, Responsabilidade Civil: De um Direito dos Danos a um Direito das Condutas Lesivas, São Paulo, Atlas, 2012.

LIMA, Alvino, Culpa e Risco, São Paulo, Revista dos Tribunais, 1960.

LISBOA, Roberto Senise, Responsabilidade Civil nas Relações de Consumo, São Paulo, Revista dos Tribunais, 2001.

LOPEZ, Teresa Ancona, O Dano Estético: Responsabilidade Civil, $3^{\mathrm{a}}$ ed., São Paulo, Revista dos Tribunais, 2004.

, Princípio da Precaução e Evolução da Responsabilidade Civil, São Paulo, Quartier Latin, 2010.

MAGALHÃES, Carlos Francisco; DIAS, Gabriel Nogueira; DEL DEBBIO, Cristiano Rodrigo, "Brazil", in GOTTS, Ilene Knable (org.), The Private Competition Enforcement Review, $4^{\text {th }}$ ed., London, Law Business Research Ltd., 2011.

MAGGI, Bruno Oliveira, O Cartel e seus Efeitos no Âmbito da Responsabilidade Civil, Dissertação de Mestrado, Faculdade de Direito da Universidade de São Paulo, 2010.

MALUF, Carlos Alberto Dabus, Código Civil Comentado - Prescrição, Decadência e Prova, vol. 3, São Paulo, Atlas, 2009.

MARANHÃO, Juliano Souza de Albuquerque; AZEVEDO, Paulo Furquim de; FERRAZ JÚNIOR, Tércio Sampaio, Direito Regulatório e Concorrencial no Poder Judiciário, São Paulo, Editora Singular, 2014. 
MARTINEZ, Ana Paula, Repressão a Cartéis: Interface entre Direito Administrativo e Direito Penal, São Paulo, Singular, 2013.

MARTINS-COSTA, Judith; PARGENDLER, Mariana Souza, "Usos e Abusos da Função Punitiva (Punitive Damages e o Direito Brasileiro)", in Revista CEJ, n. 29, Brasília, jan./mar., 2005.

MATTOS, César Costa Alves de, "Introdução à Teoria Econômica dos Cartéis", in SCHAPIRO, Mario Gomes; CARVALHO, Vinícius Marques de; e CORDOVIL, Leonor (coord.), Direito Econômico Concorrencial, São Paulo, Saraiva, 2013.

MENEZES CORDEIRO, Antonio Manuel da Rocha e, Da Boa Fé no Direito Civil, 5a reimpressão, Coimbra, Almedina, 2013.

, Direito Europeu das Sociedades, Coimbra, Almedina, 2005.

MENDONÇA, Diogo Naves, Análise Econômica da Responsabilidade Civil - O Dano e sua Quantificação, São Paulo, Atlas, 2012.

MESQUITA, José Ignácio Botelho de, “A Judicialização do Direito da Concorrência”, in Revista de Direito Mercantil, Industrial, Econômico e Financeiro, vol. 155/156, ago./dez., 2010.

MONTEIRO, Washington de Barros, Curso de Direito Civil: Direito das Obrigações, $2^{\mathrm{a}}$ Parte, 9a ed., São Paulo, Saraiva, 1973.

MONTI, Giorgio, EC Competition Law, New York, Cambridge University Press, 2007.

MORAES, Maria Celina Bodin de, Danos à Pessoa Humana: Uma Leitura CivilConstitucional dos Danos Morais, Rio de Janeiro, Renovar, 2003.

MORSELlO, Fábio Marco, "O Nexo Causal e Suas Distintas Teorias: Apreciações Críticas”, in Revista do Instituto dos Advogados de São Paulo, vol. 19, 2007. 
MOTTA, Massimo, Competition Policy: Theory and Practice, New York, Cambridge University Press, 2004.

, On Cartel Deterrence and Fines in the EU, European University Institute, Florence and Università di Bologna, October 12, 2007, disponível em: $<$ http://www.barcelonagse.eu/tmp/pdf/motta_carteldeterfines.pdf $>$. Acesso em: 23.mar.2013.

NERY Júnior, Nelson; NERY, Rosa Maria de Andrade, Leis Civis Comentadas, São Paulo, Revista dos Tribunais, 2012.

NIELS, Gunnar; JENKINS, Helen; KAVANAGH, James, Economics for Competition Lawyers, Oxford University Press, 2011.

NUSDEO, Fábio, Curso de Economia: Introdução ao Direito Econômico, $2^{\mathrm{a}}$ ed., São Paulo, Revista dos Tribunais, 1997.

OCDE, Direito e Política da Concorrência no Brasil: Uma Revisão pelos Pares, 2010, disponível em: <http://www.oecd.org/dataoecd/4/41/45154401.pdf> Acesso em: 22.mar.2013.

, Hard Core Cartels, Paris, OECD Publications Service, 2000.

, Plea Barganing/Settlement of Cartel Cases, 2006, disponível em: <http://www.oecd.org/competition/cartels/40080239.pdf>. Acesso em: 4.abr.2013.

OLIVEIRA, Gesner; RODAS, João Grandino, Direito e Economia da Concorrência, Rio de Janeiro, Renovar, 2004.

OXERA CONSULTING, Quantifying Antitrust Damages: Towards Non-Biding Guidance for Courts - Study Prepared for the European Commission, 2009, disponível em: <http://ec.europa.eu/competition/publications/>. Acesso em: 7.abr.2013. 
PARLAMENTO EUROPEU, Amendments by the European Parliament to the Commission Proposal - Directive of the European Parliament and of the Council on Certain Rules Governing Actions for Damages under National Law for Infringements of the Competition Law Provisions of the Member States and of the European Union, disponível em: <http://www.europarl.europa.eu/sides/getDoc.do?pubRef=-//EP//NONSGML+AMD+A72014-0089+002-002+DOC+PDF+V0//EN> . Acesso em: 30.out.2014.

PEREIRA, Caio Mário da Silva, Instituições de Direito Civil, vol. I, $21^{\mathrm{a}}$ ed., Rio de Janeiro, Forense, 2005.

Responsabilidade Civil, 9ª ed., Rio de Janeiro, Forense, 1999.

PFEIFFER, Roberto Augusto Castellanos, Defesa da Concorrência e Bem-Estar do Consumidor, Tese de Doutorado, Faculdade de Direito da Universidade de São Paulo, 2010 .

PIKE, Richard; RICHMOND, Francesca, "Disclosure of Leniency Materials by EU Competition Authorities: Protection in the Face of Civil Damages Claims", in Global Competition Litigation Review, disponível em: <http://www.algoodbody.ie/media/GlobalCompLitigationReview1.pdf>. Acesso em: 31.out.2014.

PINDYCK, Robert S.; RUBINFELD, Daniel L., Microeconomia, $6^{\mathbf{a}}$ ed., São Paulo, Pearson Prentice Hall, 2006.

PINHEIRO, Armando Castelar; SADDI, Jairo, Direito, Economia e Mercados, Rio de Janeiro, Editora Campus, 2005.

POLINSKY, Mitchell; SHAVELL, Steven, Handbook of Law and Economics, vol. 2, Amsterdam, North Holland, 2007.

PONTES DE MIRANDA, Francisco Cavalcanti, Tratado de Direito Privado: Parte Especial - Direito das Obrigações, Tomo LIII, $3^{\text {a }}$ ed., Rio de Janeiro, Editor Borsoi, 1972. 
Tratado de Direito Privado: Parte Especial - Direito das Obrigações, Tomo LIV, $3^{\text {a }}$ ed., Rio de Janeiro, Editor Borsoi, 1972.

POSNER, Richard A., Antitrust Law: An Economic Perspective, Chicago, University of Chicago Press, 1976. , Economic Analysis of Law, $5^{\text {th }}$ ed., New York, Aspen, 1998. , "Values and Consequences - An Introduction to Law and Economics", in POSNER, Eric (org.), Chicago Lectures in Law and Economics, New York, Foundation Press, 2000.

PRADO, Luiz Regis, Direito Penal Econômico, $3^{\text {a }}$ ed., São Paulo, Revista dos Tribunais, 2009.

PROENÇA, José Marcelo Martins (coord.), A Reforma da Lei da Concorrência - Lei $n^{o}$ 8.884/94, $1^{\mathrm{o}}$ Congresso Brasileiro de Direito Comercial, 2011, disponível em: <http://www.congressodireitocomercial.org.br/2011/images/stories/pdfs/gep12.pdf>. Acesso em: 28.nov.2014.

Concentração Empresarial e o Direito da Concorrência, São Paulo, Saraiva, 2001. , Insider Trading - Regime Jurídico do Uso de Informações Privilegiadas no Mercado de Capitais, São Paulo, Quartier Latin, 2005.

REZENDE, Gustavo Madi; KIELBER, Solange; MADI, Maria Fernanda Caporale, "Métodos de Mensuração das Indenizações Privadas em casos de Cartel”, in Revista do IBRAC, ano 18, vol. 20, 2011.

RIZZARDO, Arnaldo, Responsabilidade Civil, 5 ${ }^{\mathrm{a}}$ ed., Rio de Janeiro, Forense, 2011.

RODRIGUES, Silvio, Direito Civil - Responsabilidade Civil, vol. 4, 20ª ed., São Paulo, Saraiva, 2002. 
ROMANIELO, Enrico Spini, Direito Antitruste e Crise - Perspectivas para a Realidade Brasileira, Dissertação de Mestrado, Faculdade de Direito da Universidade de São Paulo, 2013.

ROSCH, J. Thomas, "Designing a Private Remedies System of Antitrust Cases: Lessons Learned from the U.S. Experience", in Revue des Droits de La Concurrence, n. 4, 2011.

ROSENVALD, Nelson, As Funções da Responsabilidade Civil: A Reparação e a Pena Civil, São Paulo, Atlas, 2013.

SALOMÃO FILHO, Calixto, “Apontamentos para Formulação de uma Teoria Jurídica dos Cartéis", in Regulação e Concorrência (Estudos e Pareceres), São Paulo, Malheiros, 2002.

, "Cartel: Aspectos Concorrenciais e Penais" in Regulação e Concorrência (Estudos e Pareceres), São Paulo, Malheiros, 2002.

, Direito Concorrencial, São Paulo, Malheiros, 2014.

, Direito Concorrencial - As Condutas, $2^{\mathrm{a}}$ ed., São Paulo, Malheiros, 2007.

, Direito Concorrencial - As Estruturas, $3^{\text {a }}$ ed., São Paulo, Malheiros, 2007.

SANTACRUZ, Ruy, "Cartel na Lei Antitruste: o Caso da Indústria Brasileira de Aços Planos", in MATTOS, César (coord.), A Revolução do Antitruste no Brasil - A Teoria Econômica Aplicada a Casos Concretos, São Paulo, Singular, 2003.

SANTOS, Antonio Jeová, Dano Moral Indenizável, $4^{\mathrm{a}}$ ed., São Paulo, Revista dos Tribunais, 2003.

SAVATIER, René, Traité de La Responsabilité Civil: En Droit Français, Tome I, $10^{\mathrm{e}}$ ed., Paris, Librarie Génerale de Droit et de Jurisprudence, 1951. 
, Traité de La Responsabilité Civil: En Droit Français, Tome II, $10^{\mathrm{e}}$ ed., Paris, Librarie Génerale de Droit et de Jurisprudence, 1951.

SCHREIBER, Anderson, Novos Paradigmas da Responsabilidade Civil: da Erosão dos Filtros de Reparação à Diluição dos Danos, $5^{\mathrm{a}}$ ed., São Paulo, Atlas, 2013.

SCHUARTZ, Luis Fernando, "Ilícito Antitruste e Acordos entre Concorrentes", in POSSAS, Mario Luiz (coord.), Ensaios sobre Economia e Direito da Concorrência, São Paulo, Singular, 2002.

SERPA, Pedro Ricardo e, Indenização Punitiva, Dissertação de Mestrado, Faculdade de Direito da Universidade de São Paulo, 2011.

SHAVELL, Steven, Foundations of Economic Analysis of Law, Cambridge, Harvard University Press, 2004.

SHIEBER, Benjamin, Abusos de Poder Econômico (Direito e Experiência Antitruste no Brasil e nos EUA), São Paulo, Revista dos Tribunais, 1966.

SILVA, Wilson Melo da, O Dano Moral e Sua Reparação, $2^{\mathrm{a}}$ ed., São Paulo, Forense, 1969.

SIMÃO, José Fernando, Prescrição e Decadência: Início dos Prazos, São Paulo, Atlas, 2013.

STIGLER, George J., The Organization of Industry, Chicago, University of Chicago, 1983.

STOCO, Rui, Tratado de Responsabilidade Civil: Doutrina e Jurisprudência, $7^{\mathrm{a}}$ ed., São Paulo, Revista dos Tribunais, 2007.

SULLIVAN, Lawrence A.; GRIMES, Warren S., The Law of Antitrust: An Integrated Handbook, St. Paul, Minnesota, West Group, 2000. 
SZTAJN, Rachel, "Direito e Economia", in Revista de Direito Mercantil, Industrial, Econômico e Financeiro, vol. 144, out./dez., 2006.

TAUFICK, Roberto Domingos, Nova Lei Antitruste Brasileira - A Lei 12.529/2011 Comentada e a Análise Prévia no Direito da Concorrência, Rio de Janeiro, Forense, 2012.

TEPEDINO, Gustavo, "Nexo de Causalidade - Conceito, Teorias e Aplicação na Jurisprudência Brasileira", in RODRIGUES JÚNIOR, Octávio Luiz; MAMEDE, Gladston; ROCHA, Maria Vital (coord.), Responsabilidade Civil Contemporânea: em Homenagem a Sílvio de Salvo Venosa, São Paulo, Atlas, 2011.

THEODORO JÚNIOR, Humberto, Dano Moral, 4ª ed., São Paulo, Juarez de Oliveira, 2001 .

TORNEAU, Philippe Le, La Responsabilité Civile, 2ª ed., Paris, Dalloz, 1976.

TUNC, André, La Responsabilité Civile, Paris, Economica, 1981.

VENOSA, Silvio de Salvo, Direito Civil - Responsabilidade Civil, v. 4, 10ª ed., São Paulo, Atlas, 2010.

VINEY, Genevieve; JOURDAIN, Patrice, Traité de Droit Civil: Les Conditions de La Responsabilité, 3a ed., Paris, Librarie Generale de Droit e de Jurisprudence, 2006.

VISCUSI, W. Kip; VERNON, John M., HARRINGTON JR., Joseph E., Economics of Regulation and Antitrust, $2^{\text {nd }}$ ed., Cambridge, Massachusetts Institute of Technology Press, 1995.

VRCEK, Bojana, “Overview of Europe”, in FOER, Albert A.; CUNEO Jonathan W. (org.), The International Handbook of Private Enforcement of Competition Law, Cheltenham, Edward Elgar Publishing, 2010.

WHISH, Richard, Competition Law, London, Oxford University Press, 2005. 
WILS, Wouter P., "The Relationship Between Public Antitrust Enforcement and Private Actions for Damages", in World Competition, v. 32, n. 1, 2009, disponível em: <http://papers.ssrn.com/sol3/papers.cfm?abstract_id=1296458>. Acesso em: 30.nov.2014.

ZANNONI, Eduardo A., El Daño en la Responsabilidad Civil, $3^{\mathrm{a}}$ ed., Buenos Aires, Astrea, 2005. 